Prepared for the U.S. Department of Energy

under Contract DE-AC05-76RL01830

\title{
Hydrogeology of the Hanford Site Central Plateau - A Status Report for the 200 West Area
}
GV Last
BN Bjornstad
PD Thorne
RD Mackley
JA Horner
DC Lanigan
KR Parker
BA Williams

August 2009

\section{Pacific Northwest}

NATIONAL LABORATORY

Proudly Operated by Battelle Since 1965 


\title{
DISCLAIMER
}

This report was prepared as an account of work sponsored by an agency of the United States Government. Neither the United States Government nor any agency thereof, nor Battelle Memorial Institute, nor any of their employees, makes any warranty, express or implied, or assumes any legal liability or responsibility for the accuracy, completeness, or usefulness of any information, apparatus, product, or process disclosed, or represents that its use would not infringe privately owned rights. Reference herein to any specific commercial product, process, or service by trade name, trademark, manufacturer, or otherwise does not necessarily constitute or imply its endorsement, recommendation, or favoring by the United States Government or any agency thereof, or Battelle Memorial Institute. The views and opinions of authors expressed herein do not necessarily state or reflect those of the United States Government or any agency thereof.

\author{
PACIFIC NORTHWEST NATIONAL LABORATORY \\ operated by \\ BATTELLE \\ for the \\ UNITED STATES DEPARTMENT OF ENERGY \\ under Contract DE-ACO 5-76RLO1830 \\ Printed in the Inited States of America \\ Available to DOE and DOE contractors from the \\ Office of Scientific and Technical Information, \\ P.O. Box 62, Oak Ridge, TN 37831-0062; \\ ph: (865) 576-8401 \\ fax: (865) 576-5728 \\ email: reports@a adonis.osti.gov

\footnotetext{
Available to the public from the National Technical Information Service,

U.S. Department of Commerce, 5285 Port Royal Ru., Springlield, VA 22161

ph: (800) 553-6847

fax: (703) $605-6900$

email: orders $\vec{a}$ ntis.fedworld.gov

online ordering: http://www.ntis.gov/ordering.htm
}

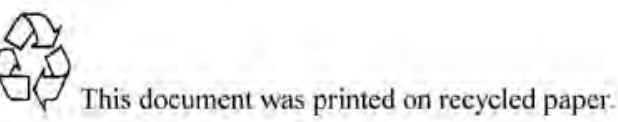

(9/2003) 


\title{
Hydrogeology of the Hanford Site Central Plateau - A Status Report for the $\mathbf{2 0 0}$ West Area
}

\author{
GV Last \\ BN Bjornstad \\ PD Thorne \\ RD Mackley \\ JA Horner \\ DC Lanigan \\ KR Parker \\ BA Williams $^{(a)}$
}

August 2009

Prepared for

the U.S. Department of Energy

under Contract DE-AC05-76RL01830

Pacific Northwest National Laboratory

Richland, Washington 99352

(a) CH2M HILL Plateau Remediation Company

Richland, Washington 99354 


\section{Preface}

This technical report was originally completed in June 2008 for limited distribution to Fluor Hanford, Inc., then manager of the Groundwater Remediation Project. CH2M HILL Plateau Remediation Company assumed management of the Groundwater Remediation Project in October 2009. Their staff and subcontractor staff completed a review of the report during spring 2009. Those comments led to significant improvements to this final report. 


\section{Summary}

The Remediation Decisions Support (RDS) function of the Soil and Groundwater Remediation Project (managed by CH2M HILL Plateau Remediation Company [CHPRC]) is responsible for facilitating the development of consistent data, parameters, and conceptual models to resolve technical issues and support efforts to estimate contaminant migration and impacts (i.e., the assessment process). In particular, the RDS function is working to update electronic data sources and conceptual models of the geologic framework and associated hydraulic and geochemical parameters to facilitate traceability, transparency, defensibility, and consistency in support of environmental assessments. This report summarizes the efforts conducted by Pacific Northwest National Laboratory (PNNL) scientists in fiscal year 2008 (FY08) that focused primarily on the 200 West Area, as well as a secondary effort initiated on the 200 East Area.

This work relied heavily on previous geologic data compilations and conceptual models developed for the Hanford Site and Central Plateau, as well as on recent efforts to standardize, manage, and analyze borehole (and other subsurface) geologic data. The aim of this work is to support development of a regional stratigraphic hydrogeologic model to constrain the spatial distribution of physical, hydrological, and geochemical properties.

The technical approach for this work was to assemble a regional stratigraphic model for the Central Plateau using previously published interpretations of the major geologic units to refine and update a database of major stratigraphic contacts. Best-estimate contacts and ground-surface elevations were then selected, based on professional judgment and general consensus, and a three-dimensional solid-earth geologic model developed of these major stratigraphic units. Anomalies in the geologic model and boreholes with high variability for specific contacts were reevaluated to verify or revise the best-estimate geologic contacts relative to raw and standardized borehole data.

Best-estimate stratigraphic contacts were compiled for 447 wells and boreholes in and adjacent to the 200 West Area. The primary approach for this work was to build on the existing database compiled by B. N. Bjornstad of PNNL, convert it from an elevation-based database to a depth-below-ground-surface database, update it with additional documented and new geologic contact information and to select bestestimate contact values to be used in the a priori geologic model of the 200 West Area.

Stratigraphic contact values (either in elevation or depth) were compiled from 17 published documents as well as some unpublished data sources, where contact information had been tabulated and/or graphically displayed on cross sections or structure contour maps. Many of these documents and data sources used different nomenclature and level of detail to call out specific stratigraphic contacts. To provide the integrated physical model presented in this document, the stratigraphy used in each document was mapped to a common set of stratigraphic units. Once the data were compiled, all contact values were converted to depth-below-ground-surface and best-estimate values selected for each well or borehole. While this compilation most likely is incomplete, it is believed to represent the bulk (i.e., 90\%) of available tabulated data sets.

Best estimates for the ground-surface elevation (presumably at the time of drilling, sampling, and geophysical logging) were also compiled using vertical survey values from the Hanford Well Information System. These two best-estimate data sets (the stratigraphic contacts, in depth in feet, and the 
ground-surface elevation, in meters) were used to develop best-estimate stratigraphic contact elevations (in meters) for input into EarthVision ${ }^{1}$ and generation of a solid model representation of the geology beneath the 200 West Area.

Uncertainties and anomalies identified in the best-estimate databases and solid model were prioritized for in-depth review and analysis of selected borehole data for verification and validation of selected contacts and to resolve discrepancies. The three-dimensional stratigraphic model documented in this report presents the current, integrated understanding of the subsurface beneath the 200 West Area. The hydrogeologic conceptual model for the Central Plateau will continue to evolve as new stratigraphic contact data sets are assembled for the 200 East Area and the 200 North Area and as new information is developed regarding physically based property transport models and upscaling.

\footnotetext{
${ }^{1}$ EarthVision ${ }^{\circledR}$ is a registered trademark of Dynamic Graphics, Inc., Alameda, California.
} 


\section{Acknowledgments}

The authors acknowledge the valuable contributions of staff and interns who willingly contributed their time and energy to standardize borehole geologic data sets and produce summary logs for boreholes in the Central Plateau. A number of these individuals also developed cross sections and geologic contact interpretations of selected data sets that have been integrated into this study. In particular, we acknowledge the contributions of Kelsey Winsor, Tamara Jeppson, Nicole McMahon, Randell Taylor, James Reider, and Steve Forrester.

The authors also acknowledge the contributions of technical reviewers, including Virginia Rohay and Marcus Wood (CH2M HILL Plateau Remediation Company) and Chris Murray (Pacific Northwest National Laboratory) for his technical reviews of both the original 2008 report and the revised 2009 version. Special thanks are provided also to Andrea Currie for copyediting, editorial reviews, and managing document production and to Kay Hass for text processing support for the 2009 version of this technical report. 


\section{Acronyms and Abbreviations}

3D

three-dimensional

CERCLA

CHPRC

CRBG

DOE

FH

FY

HBGIS

HEIS

HWIS

NAVD88

NEPA

NGVD29

PNNL

RCRA

RDS

borehole

boring

logplot

stickup

well

Fluor Hanford, Inc.

fiscal year abandoned. create them. surface.

Comprehensive Environmental Response, Compensation, and Liability Act of 1980

CH2M HILL Plateau Remediation Company

Columbia River Basalt Group

U.S. Department of Energy

Hanford Borehole Geologic Information System

Hanford Environmental Information System

Hanford Well Information System

North American Vertical Datum of 1988

National Environmental Policy Act of 1969

National Geodetic Vertical Datum of 1929

Pacific Northwest National Laboratory

Resource Conservation and Recovery Act of 1976

Remediation Decision Support

\section{Definitions of Terms}

A circular hole drilled into soil or rock for subsurface sampling or construction of a well (ASTM D 4750, http://wapi.isu.edu/envgeo/glossary.html).

A temporary borehole intended for one-time use that is immediately grouted and

Informal term for a one-dimensional graphical plot used to visualize borehole geologic data. Vertical changes in sedimentary, lithologic, geophysical, chemical, and other physical properties are shown using a variety of colors, textures, patterns, and textual comments. The term logplot is similar to, but distinct from, the name of a software program, $\operatorname{LogPlot}{ }^{1}$, used in the industry to create them. The informal term is preferred when discussing the graphical plots themselves and not the software package used to

Informal term for the distance the well casing extends (sticks up) above the ground

A permanent to semi-permanent borehole (often cased) designed for long-term repeated use.

\footnotetext{
${ }^{1}$ LogPlot $^{\mathrm{TM}}$ is a trademark of RockWare Inc., Golden, Colorado.
} 


\section{Contents}

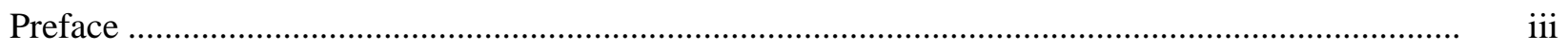

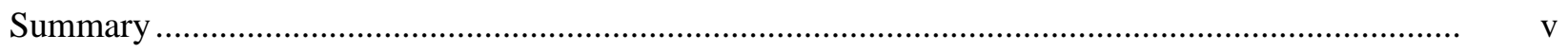

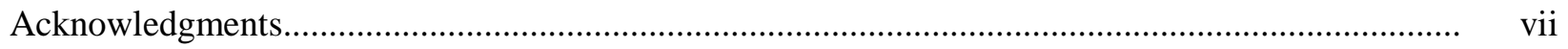

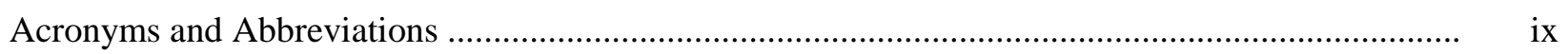

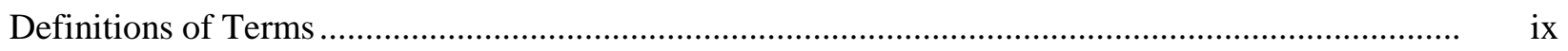

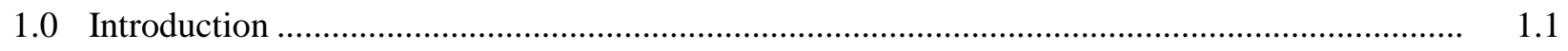

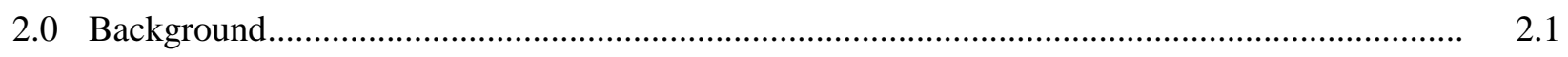

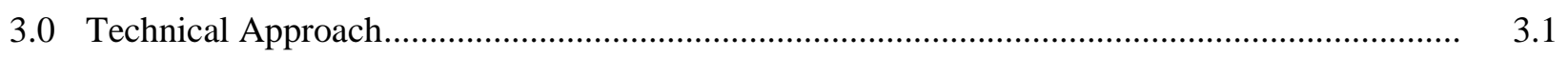

3.1 Assemble Initial Large-Scale Stratigraphic Model ........................................................ 3.1

3.1.1 Revise and Update Stratigraphic Contact Database ............................................. 3.1

3.1.2 Generate Initial Stratigraphic Model ................................................................ 3.2

3.1.3 Evaluate Areas of High Variability or Uncertainty ….......................................... 3.2

3.2 Reduce Uncertainty and Improve Traceability ............................................................. 3.2

3.2.1 Select Boreholes and Other Data Sources for Supplemental Data Analysis............ 3.2

3.2.2 Borehole Data Analysis and Refinement of Best-Estimate Contacts....................... 3.2

3.3 Revise and Update Contacts Database and Stratigraphic Model ..................................... 3.4

4.0 Regional Geology of the Pasco Basin and Hanford Site .....................................................

4.1 Columbia River Basalt Volcanism and Deposition of the Ellensburg Formation............... 4.1

4.2 Deposition of the Ringold Formation..................................................................................

4.3 Incision of the Ringold Formation and Deposition of Isolated Cold Creek Unit

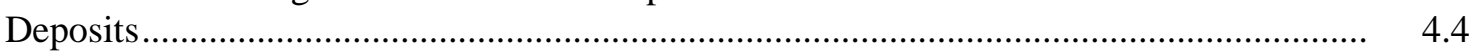

4.4 Ice Age Flooding and Deposition of the Hanford formation ........................................... 4.4

4.5 Holocene Deposits..................................................................................................... 4.5

5.0 Stratigraphic Contacts Beneath the Central Plateau ........................................................ 5.1

5.1 Stratigraphic Nomenclature.................................................................................... 5.1

5.2 Stratigraphic Contact Data ...................................................................................... 5.2

5.3 Evaluation and Verification of Best-Estimate Contacts to Raw Borehole Data ................. 5.11

5.4 Ground-Surface Elevation Data ............................................................................. 5.11

5.5 Contact Elevations............................................................................................... 5.13

6.0 Stratigraphic Model of the Central Plateau .................................................................. 6.1

6.1 Three-Dimensional Model ........................................................................................... 6.1

6.2 Detailed Geologic Cross Sections .......................................................................... 6.13

6.2.1 North-South Cross Section........................................................................ 6.17

6.2.2 East-West Cross Section ................................................................................ 6.18

7.0 Physical, Hydraulic, and Geochemical Properties................................................................. 7.1

7.1 Mineralogy, Petrology, and Bulk Rock Geochemistry ................................................ 7.1

7.1.1 Hanford Formation ................................................................................. 7.1 


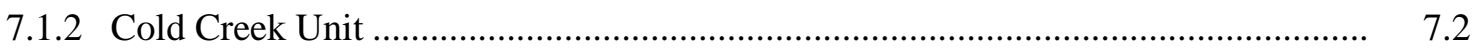

7.1.3 Ringold Formation .................................................................................... 7.2

7.2 Contaminant Distribution Coefficients ...................................................................... 7.2

7.3 Limitations and Data Gaps ....................................................................................... 7.2

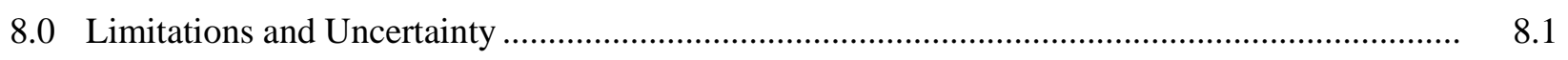

8.1 Uncertainty in Stratigraphic Interpretations ............................................................... 8.1

8.1.1 Identification of Geologic Units and Contacts ................................................ 8.1

8.1.2 Vertical Survey and Depth Control ..................................................................... 8.1

8.1.3 Depth and Thickness of Sedimentary Units ......................................................... 8.2

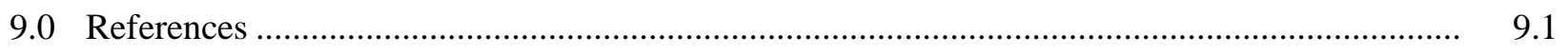

Appendix A - Stratigraphic Contacts for the 200 West Area and Vicinity .................................... A.1

Appendix B - Best-Estimate Ground-Surface Elevations for Wells and Boreholes in and Around the 200 West Area ...................................................................................... B.1

Appendix C - Geologic Model of the 200 West Area................................................................ C.1

Appendix D - Detailed Geologic Cross Sections Through the 200 West Area.............................. D. D.1 


\section{Figures}

2.1 Location of the Central Plateau and 200 West Area .............................................................. 2.2

4.1 Main Structural Features of the Pasco Basin and Surrounding Area ........................................ 4.2

5.1 Correlation of Stratigraphic Units Used by Different Investigators to Those Used in This Report ...

5.2 Location of Boreholes in and Adjacent to the 200 West Area, with Stratigraphic Contact Data.....

5.3 Location of Boreholes in and Adjacent to the 200 West Area, for Which Logplots Are Available

6.1 EarthVision Model Domain for the 200 West Area Geologic Model.

6.2 Three-Dimensional Geologic Model with Cutout Through the Central and Northern 200 West Area, Approximating Cross Sections B-B' and F-F'

6.3 Structure Contour Map for the Top of the Hanford H1 Unit in and Around the 200 West Area.

6.4 Structure Contour Map for the Top of the Hanford H2 Unit in and Around the 200 West Area.

6.5 Structure Contour Map for the Top of the Hanford H3 Unit in and Around the 200 West Area.

6.6 Structure Contour Map for the Top of the Cold Creek Unit Silt in and Around the 200 West Area

6.7 Structure Contour Map for the Top of the Cold Creek Unit Carbonate Unit in and Around the 200 West Area..

6.8 Structure Contour Map for the Top of the Ringold Formation, Member of Taylor Flat, in and Around the 200 West Area....

6.9 Structure Contour Map of the Top of the Ringold Formation, Member of Wooded Island, Unit E, in and Around the 200 West Area

6.10 Structure Contour Map of the Top of the Ringold Formation, Lower Mud Unit, in and Around the 200 West Area

6.11 Structure Contour Map of the Top of the Ringold Formation, Member of Wooded Island, Unit A, in and Around the 200 West Area

6.12 Structure Contour Map of the Top of Basalt in and Around the 200 West Area...

6.13 Location of Potential and Completed Cross Sections

6.14 North-South Cross Section B-B'

6.15 East-West Cross Section F-F'

6.16 North-South Cross Section Through the Solid-Earth Geologic Model Coincident with That of Cross Section B-B'

6.17 West-East Cross Section Through the Solid Earth Geologic Model Coincident with That of Cross Section F-F'. 


\section{Tables}

3.1 Point System for Prioritizing Borehole Data Analyses ...........................................................

5.1 Stratigraphic Nomenclature and Symbols Used in This Report.............................................. 5.3

5.2 Sources of Stratigraphic Contacts Data for the 200 West Area ............................................... 5.5 


\subsection{Introduction}

The U.S. Department of Energy (DOE) Hanford Site is the site of the largest and most complex environmental cleanup project in the United States (Gephart 2003). Cleanup decisions have focused predominantly on remediating individual aspects of the larger system. However, the DOE "Report to the House and Senate Committees on Appropriation on Groundwater Vadose Zone Organization and Operations at the Hanford Site" ${ }^{1}$ indicates that future cleanup decisions will be based on a systems approach, such that remedial actions are sequenced and mutually supported, and based on an integrated understanding of how contaminants move through the environment. To this end, DOE is taking efforts to ensure that a consistent set of data, conceptual models, and numerical approaches are used in support of environmental assessments performed for the National Environmental Policy Act (NEPA), the Comprehensive Environmental Response, Compensation, and Liability Act (CERCLA), and the Resource Conservation and Recovery Act (RCRA).

The Remediation Decision Support (RDS) project at Pacific Northwest National Laboratory (PNNL) supports the RDS function of the Soil and Groundwater Remediation Project (managed by CH2M HILL Plateau Remediation Company [CHPRC]). The RDS function is responsible for facilitating the development of consistent data, parameters, and conceptual models to resolve technical issues and support efforts to estimate contaminant migration and impacts (i.e., the assessment process). In particular, the RDS function is working to update electronic data sources and conceptual models of the geologic framework and associated hydraulic and geochemical parameters to facilitate traceability, transparency, defensibility, and consistency in support of environmental assessments.

The objective of this report is to summarize the status of efforts conducted in Fiscal Year 2008 (FY08) to update the hydrogeologic conceptual model for the Hanford Site Central Plateau Area. The scope of this work was focused primarily on the 200 West Area, with a secondary effort initiated on the 200 East Area. The aim of this work is to provide a comprehensive overview of the available hydrogeologic data and conceptual model(s) of the subsurface framework, building on previous compilations by Tallman et al. (1979); Lindsey (1991, 1992); Connelly et al. (1992a, 1992b); Williams et al. (2000, 2002); and Reidel and Chamness (2007).

This report contains nine sections and four appendices. Section 2 provides background on the Hanford Site Central Plateau and the need for a unified conceptual model of its hydrogeologic framework. Section 3 outlines the technical approach used to assemble and integrate available data and information into a holistic understanding of the Central Plateau hydrogeology. Section 4 provides an overview of the geologic history of the Pasco Basin and Hanford Site, to provide context for development of a sequence stratigraphic hydrogeologic model for the Central Plateau. Section 5 describes development and refinement of a stratigraphic contacts database to define the tops of major stratigraphic units (e.g., formations, members, and mappable facies associations). Section 6 describes the development of a largescale three-dimensional stratigraphic model of the Central Plateau (focusing on the 200 West Area). Section 7 presents a summary of the existing physical and hydraulic properties for stratigraphic units and associated lithofacies defined in the 3D stratigraphic model. Also described in Section 7 are the

\footnotetext{
${ }^{1}$ Rispoli JA. 2006. Letter to the Honorable Thad Cochran (Chairman, Senate Appropriations Committee) from James A. Rispoli (Assistant Secretary for Environmental Management, U.S. Department of Energy), March 29, 2006.
} 
petrologic, mineralogic, bulk rock geochemistry, and other geochemical properties of the subsurface that contribute to understanding the provenance, stratigraphic correlation, and contaminant retardation properties of the stratigraphic units and intra-unit facies. Section 8 describes the limitations and sources of errors associated with compilation of the stratigraphic contacts, development of the geologic model, and assignment of physical, hydrologic, and geochemical properties. Literature sources cited in the report are listed in Section 9. Appendix A contains the stratigraphic contacts database, Appendix B contains the ground-surface database, Appendix $\mathrm{C}$ contains the geologic model data and graphical image files, and Appendix D illustrates selected detailed geologic cross sections through the 200 West Area. 


\subsection{Background}

The Hanford Site Central Plateau encompasses about $194 \mathrm{~km}^{2}\left(75 \mathrm{mi}^{2}\right)$ near the center of the Hanford Site (Figure 2.1). It contains the 200 West Area and 200 East Area, referred to as Separations Areas. These areas once housed five chemical separations buildings and other facilities that separated and recovered plutonium and other special nuclear materials. Process operations and waste management activities resulted in the storage and disposal of large quantities of solid and liquid wastes. More than 1.7 billion $\mathrm{m}^{3}$ (450 billion gal) of liquid waste, some containing radionuclides and hazardous chemicals, have been discharged to the ground, with much of the contamination remaining above the water table. Cleanup of the Central Plateau is organized into several different CERCLA-related operable units and RCRA-related waste management units.

The geologic framework of the subsurface is the physical structure that, along with hydrologic and geochemical properties, controls the migration and distribution of contaminants. Of particular interest are the interrelationships between the coarser- and finer-grained facies, and the degree of contrast in their physical and geochemical properties. These interrelationships are often linked in predictable ways to small-scale lithofacies heterogeneity and larger-scale stratigraphic packaging (Fogg et al. 1989; Anderson 1990). Heinz et al. (2003) recognized three scales of heterogeneity: 1) large architectural-scale heterogeneities among major unconformity-bound stratigraphic sequences (e.g., Formations), 2) intermediate-scale heterogeneities of depositional sequences or sedimentary packages (e.g., Members), and 3) small-scale heterogeneities of discrete lithofacies within the larger sedimentary sequences. Last et al. (2007) recognized that even finer-scale (fourth-order) heterogeneities could occur within lithofacies. The primary focus of this work is to refine and improve traceability of a large-scale geologic model for the Central Plateau that captures both formation and subformation stratigraphic units (i.e., first-and second-order heterogeneities).

A unified conceptual model (including uncertainties and alternative conceptual models) of the largerscale hydrogeologic framework for both the vadose zone and groundwater throughout the entire Central Plateau is needed to provide the defensible technical basis for, and consistency among, the conceptual site models developed for operable units and waste management units. Often there are boundary faults (arbitrary discontinuities and inconsistencies) among projects and differences in stratigraphic nomenclature - this has led to confusion and reduced credibility with regulators.

The most-recent holistic geologic conceptual model completed for the Central Plateau was done in 1979 by Tallman et al. Updates to the 200 East Area and 200 West Area hydrogeologic conceptual models completed to support the Central Plateau remediation were conducted in 1991 and 1992 (Lindsey 1991, 1992; Connelly et al. 1992a, 1992b). Additional updates relative to the hydrogeology of the suprabasalt aquifer beneath the 200 East and 200 West Areas were conducted in 2000 and 2002, respectively (Williams et al. 2000, 2002). However, several hundred wells have been drilled since then, providing much-needed data to refine the large-scale stratigraphic units and resolve discrepancies among nomenclature and project- and site-specific interpretations. 


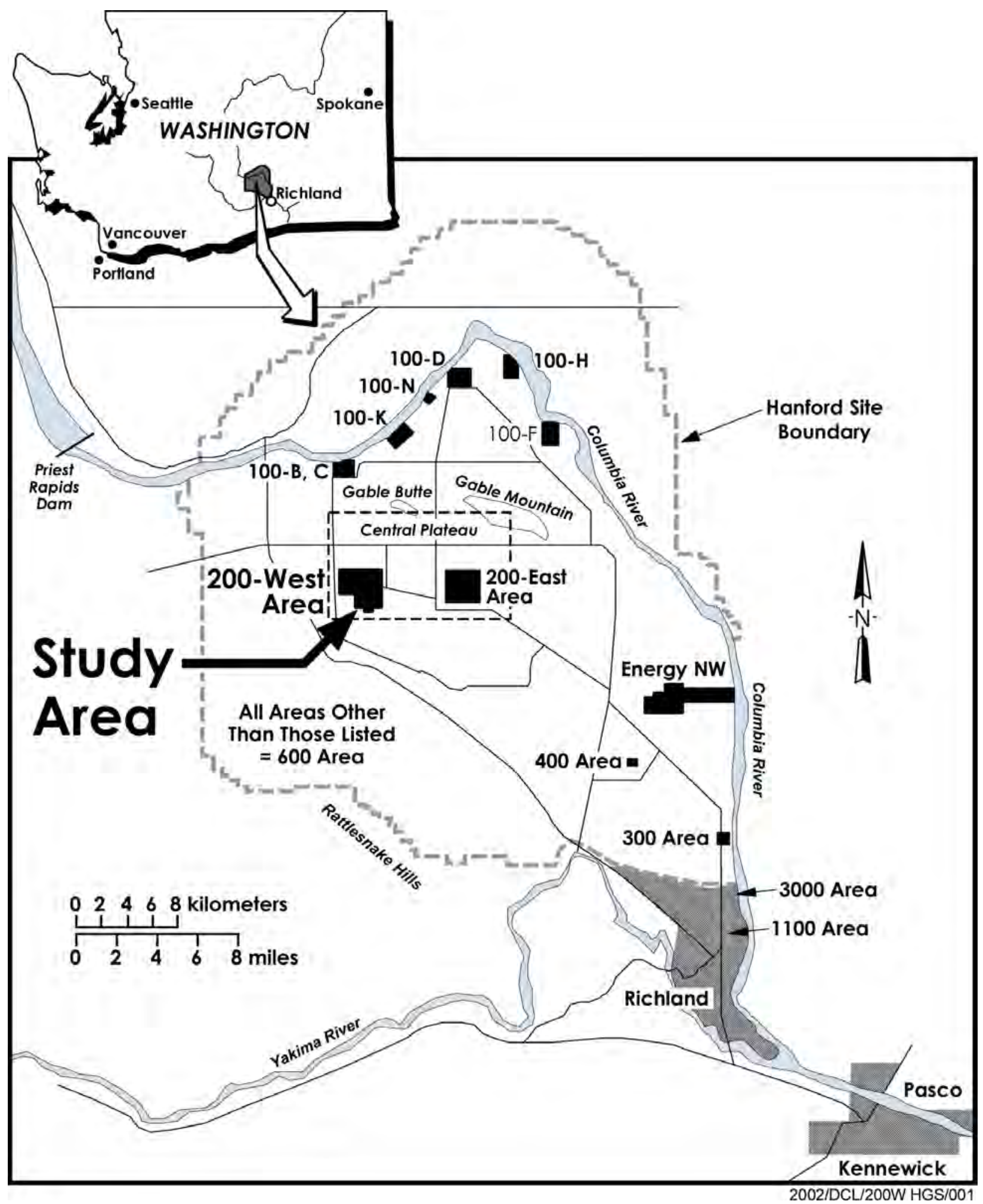

Figure 2.1. Location of the Central Plateau and 200 West Area (after Williams et al. 2002) 
Recent studies in 2002 and 2007 have revised and updated the nomenclature (DOE 2002) and presented a geologic data package for selected portions of the Central Plateau but have left gaps or raised new issues regarding that holistic understanding of the hydrogeology of the Central Plateau. Williams et al. $(2000,2002)$ updated the hydrogeologic conceptual model for the supra-basalt aquifer beneath the 200 East and 200 West Areas but did not address the vadose zone. Reidel and Chamness (2007) updated the geology of the single-shell tanks waste management areas but provided limited data on the areas between. Bjornstad and Lanigan (2007) updated the geology of the Low-Level Burial Grounds but did not address other areas. Furthermore, recent borehole data, particularly from northeast of the 200 West area, suggest that refinements to the existing geologic model are needed.

Traditional approaches to modeling the stratigraphic framework at the Hanford Site have used simple homogeneous and horizontally stratified hydrogeologic units. However, as computer-processing capabilities have advanced, more emphasis has been placed on improving spatial resolution and quantifying uncertainty in representing the geologic framework and its key model parameters. Newer approaches are focusing on geostatistical simulation of the sequence-stratigraphic relations of lithofacies and on the geostatistical distribution of flow-and-transport properties within those facies. These newer approaches require more rigorous quantitative treatment of geologic data than are normally supported by the mostly qualitative nature of borehole geologic information. Thus, efforts are being made to standardize borehole geologic data so they can be used in a systematic and quantitative way to define the spatial distribution of flow-and-transport properties (Last et al. 2007, p. 906). These efforts improve traceability of the interpreted large-scale stratigraphic contacts relative to the raw and standardized borehole data sets. 


\subsection{Technical Approach}

The scope of work for FY08 was focused primarily on the 200 West Area; a secondary effort focused on the 200 East Area was initiated. The technical approach for this work was to assemble a regional stratigraphic model for the Central Plateau using previously published interpretations of the major geologic units to refine and update a database of major stratigraphic contacts. Best-estimate contacts and ground-surface elevations were then selected, based on professional judgment and general consensus, to develop a three-dimensional solid-earth geologic model of the major stratigraphic units. Anomalies in the geologic model and boreholes with high variability for specific contacts were reevaluated to verify the best-estimate geologic contacts relative to raw and standardized borehole data. A brief description of the technical activities and methodologies used is provided in this section. Note that many of these activities were conducted in parallel to hasten completion of the work.

\subsection{Assemble Initial Large-Scale Stratigraphic Model}

The objective of this activity was to assemble a large-scale stratigraphic model of the Central Plateau to capture existing published interpretations on the major heterogeneities within the subsurface framework distinguished by unconformity-bounded stratigraphic sequences, most of which correspond to geologic formations. Where possible, intermediate-scale stratigraphic units representing second-order heterogeneities identified by depositional sedimentary sequences or packages (e.g., members and facies associations) also were included. Their inclusion was accomplished by revising and updating an existing stratigraphic contacts database (Bjornstad 2004), assembling the geologic model, and evaluating areas of high variability or uncertainty to focus additional data analysis.

\subsubsection{Revise and Update Stratigraphic Contact Database}

One of the first activities was to revise and update the existing stratigraphic contact database (Bjornstad 2004) with new interpretive data published in more recent documents (e.g., Reidel and Chamness 2007) or from unpublished sources. The stratigraphic contacts database was revised to capture the depths of stratigraphic contacts in feet below ground surface to make the stratigraphic contact interpretations more easily traceable to raw and standardized borehole data. Necessarily, a database of best-estimate ground-surface elevations at the time of drilling also had to be developed such that contact elevations could be calculated. During FY08, the stratigraphic contacts database for the 200 West Area and its surroundings was revised and updated, and a new best-estimate ground-surface elevation database was developed. Where multiple contact interpretations were found for an individual borehole, a bestestimate set of contacts was selected based on the traceability and defensibility of the contact estimates, professional judgment, and a general consensus among the various contacts. Details on the development of the stratigraphic contacts database and best-estimate ground-surface elevation database for the 200 West Area are provided in Section 5. Efforts to revise and update the stratigraphic contacts database for the 200 East Area and its surroundings also were initiated. However, these data are not complete, have not been reviewed, and lack selection of the best estimates, nor has a best-estimate ground-surface elevation database been developed for the 200 East Area. Thus, neither the stratigraphic contacts database nor the geologic model for the 200 East Area is discussed further in this report. 


\subsubsection{Generate Initial Stratigraphic Model}

The objective of this activity was to develop a geologic model of the major stratigraphic units contained in the stratigraphic contacts database. Stratigraphic contact elevations, in meters, calculated from the stratigraphic contacts database and the best-estimate ground-surface elevation database, were used to develop a 3D solid model of the stratigraphic structure beneath the 200 West Area. This was accomplished using EarthVision ${ }^{1}$ software. The resulting geologic model was then used to graphically display structure contour and isopach maps, cross sections, and solid model representations of the major stratigraphic contact surfaces and unit thicknesses.

\subsubsection{Evaluate Areas of High Variability or Uncertainty}

An evaluation of potential anomalies in the spatial geometry of individual stratigraphic units within the solid model and variability within the stratigraphic contact database was used to identify key data gaps and conflicting interpretations. Those spatial locations and boreholes with the greatest variability or uncertainty were selected for further data analysis. Among those boreholes selected for further data analysis were 299-W11-6, 299-W26-12, 699-37-82B, 699-37-84, 699-45-69A \& C, and 699-48-77A \& C.

\subsection{Reduce Uncertainty and Improve Traceability}

Additional data analysis was conducted to reduce uncertainty in the geologic model and to improve traceability of the geologic contact interpretations to raw borehole data.

\subsubsection{Select Boreholes and Other Data Sources for Supplemental Data Analysis}

Key boreholes and other data sources (e.g., near-surface outcrops, surface geophysical survey data) were selected for detailed geologic interpretation, based on uncertainties in the geologic model or contacts database and the availability of data from newly drilled boreholes. Their selection involved development of criteria (e.g., location, quantity and quality of data) for selection and ranking to prioritize boreholes for data entry and analysis and to help weight the interpretation of contact picks and correlations used in the conceptual model (Table 3.1). Note: geologic contact picks in those wells with a higher quality and quantity of data, which provide more confidence, are given higher weight compared to other wells with poorer-quality data.

\subsubsection{Borehole Data Analysis and Refinement of Best-Estimate Contacts}

Borehole data (including geophysical logs) from new boreholes and selected high-priority boreholes were standardized and entered into the Hanford Borehole Geologic Information System (HBGIS) to produce summary logplots of the standardized raw borehole data. These summary logplots and their supporting data were used to define, refine, or verify the major stratigraphic contacts (formation, major facies associations) and to improve traceability of the interpretations directly back to the raw borehole data.

\footnotetext{
${ }^{1}$ EarthVision ${ }^{\circledR}$ is a registered trademark of Dynamic Graphics, Inc., Alameda, California.
} 
Table 3.1. Point System for Prioritizing Borehole Data Analyses

\begin{tabular}{|c|c|}
\hline Borehole Information Ranking Criteria (maximum points) & Points \\
\hline \multicolumn{2}{|l|}{ Borehole depth (20) } \\
\hline Bottom in basalt & 20 \\
\hline Bottom in CCU or Ringold Formation & 10 \\
\hline Bottom in Hanford formation & 0 \\
\hline$<100 \mathrm{ft}$ & -10 \\
\hline \multicolumn{2}{|l|}{ Drill Method (20) } \\
\hline$>50 \%$ split spoon or diamond core & 20 \\
\hline $25 \%-50 \%$ split spoon & 15 \\
\hline $100 \%$ drive barrel & 10 \\
\hline 100\% hard tool, air rotary, ODEX, sonic, and/or Becker hammer & 5 \\
\hline Cone penetrometer & 0 \\
\hline \multicolumn{2}{|l|}{ Field Logs (35) } \\
\hline Geologists' log & 30 \\
\hline Drillers' log & 5 \\
\hline Neither & 0 \\
\hline \multicolumn{2}{|l|}{ Geophysical Logs (40) } \\
\hline Gross gamma & 10 \\
\hline Spectral gamma & 10 \\
\hline Neutron moisture & 20 \\
\hline No geophysical logs & 0 \\
\hline \multicolumn{2}{|l|}{ Physical Properties (50) } \\
\hline Grain size (ROCSAN) & 30 \\
\hline Lab moisture & 15 \\
\hline Other physical measurements (e.g., permeability, density, porosity) & 10 \\
\hline \multicolumn{2}{|l|}{ Chemical Properties (20) } \\
\hline $\mathrm{CaCO}_{3}(\mathrm{ROCSAN})$ & 10 \\
\hline $\begin{array}{l}\text { Other chemical measurements (e.g., mineralogy, x-ray fluorescence, x-ray diffraction, } \\
\text { water/acid extracts, anions, cations, cation exchange capacity, metals) }\end{array}$ & 10 \\
\hline \multicolumn{2}{|l|}{ Other (15) } \\
\hline Age dating (paleomagnetic signatures, carbon-14, other radiometric dates) & 5 \\
\hline Digital photographs of core and cuttings & 5 \\
\hline Maximum number of points possible & (200) \\
\hline Rank & Points Range \\
\hline 1 (best) & $101-200$ \\
\hline 2 & $71-100$ \\
\hline 3 & $41-70$ \\
\hline 4 & $21-40$ \\
\hline 5 (worst) & $0-20$ \\
\hline
\end{tabular}

Logplots and supporting data from individual new boreholes were compared with the logplots and data from existing nearby boreholes (particularly when a borehole with poor data is adjacent to boreholes with good data) to improve consistency and confidence in the interpretations. For lower-priority boreholes for which standardized semiquantitative data are not fully available, qualitative subjective analyses were conducted to check against contact interpretations from previous reports. 


\subsection{Revise and Update Contacts Database and Stratigraphic Model}

New and revised best-estimate stratigraphic contact interpretations were incorporated into the stratigraphic contact database following change control protocols. The revised and updated best-estimate contacts were then used to generate a revised 3D solid model of the stratigraphy beneath the 200 West Area. This geologic model was used to develop structure contour and isopach maps, cross sections, and solid model representations of the major stratigraphic contact surfaces and unit thicknesses.

Detailed cross sections were constructed independently of the 3D solid model using interpreted and raw borehole data for selected boreholes along selected transects, to provide another consistency check of the stratigraphic contacts database. The larger-scale stratigraphic correlations were used to further refine and adjust the sequence stratigraphic model to honor major lithologic changes that are correlative between multiple boreholes and to revise the stratigraphic contacts database and solid model as needed. Reanalysis of the uncertainty in the geologic model provides a measure of the improvements to the revised model and identifies the next priorities for reducing the data gaps and resolving conflicting interpretations. Some degree of iteration was necessary to revise and refine the geometry and orientation of the major stratigraphic units. The revised stratigraphic conceptual model will be placed under configuration control using the stratigraphic contacts and ground-surface elevation databases, the EarthVision input files, and resulting graphics and shape files. 


\subsection{Regional Geology of the Pasco Basin and Hanford Site}

This section provides an overview of the geologic history of the Pasco Basin and Hanford Site, to provide context and defensibility for development of a sequence stratigraphic hydrogeologic model for the Central Plateau. This discussion is taken largely from a previous overview of the geologic history of the Hanford Site and Central Plateau provided by Reidel and Chamness (2007). An understanding of the geologic history of the area is key to interpretation of the major stratigraphic units and their spatial configuration. Of primary interest to this study are the large unconformity-bound sedimentary sequences overlying the basalt bedrock.

The Hanford Site lies within the Pasco Basin, which is a structural and topographic basin within the Yakima Fold Belt structural subprovince of the Columbia Plateau (Myers et al. 1979, p. II-72). The Columbia Plateau is a broad plain situated between the Cascade Range to the west and the Rocky Mountains to the east, and is underlain by the Miocene Columbia River Basalt Group (CRBG) (Figure 4.1). Structural basins within the Yakima Fold Belt, including the Pasco Basin, are filled with sedimentary sequences from ancestral river systems, cataclysmic Ice Age floods, and localized deposits of coluvium and loess. The broad chronology of these events is described in the following sections.

\subsection{Columbia River Basalt Volcanism and Deposition of the Ellensburg Formation}

During the period from 17 to 6 million years ago, vast quantities of tholeiitic flood-basalt erupted from north-northwest-trending fissures or linear vent systems in north-central and northeastern Oregon, eastern Washington, and western Idaho (Swanson et al. 1979b). These basalt flows constitute the Columbia River Basalt Group (CRBG) that forms the main bedrock of the Pasco Basin and Hanford Site. The CRBG consists of more than 200,000 $\mathrm{km}^{3}$ of basalt flows that cover approximately 230,000 $\mathrm{km}^{2}$ (Camp et al. 2003). Some eruptions had volumes as great as 5,000 $\mathrm{km}^{3}$ (Reidel et al. 1989), with the greatest amounts being erupted between 16.5 and 14.5 million years before present.

Subsidence during and since the Columbia River basalt volcanism formed the Pasco Basin, while other tectonic forces folded the basalt flows into narrow anticlinal ridges and broad synclinal valleys (Reidel et al. 1989). Weathering, soil development, erosion, and/or sediment deposition occurred between eruptions, particularly between the younger basalt flows. Intercalated with and, in some places, overlying the CRBG are sedimentary rocks of the Ellensburg Formation (Swanson et al. 1979a). In the western Columbia Basin, the Ellensburg Formation is mostly volcanic-derived sediment; in the central and eastern basin, fluvial sediments of the ancestral Clearwater and Columbia Rivers form the dominant lithologies (Fecht et al. 1987).

Based on chemical composition, paleomagnetic data, lithology, and stratigraphic correlation, the CRBG has been divided into five formations (Swanson et al. 1979b) — the Picture Gorge Basalt, the Imnaha Basalt, the Grande Ronde Basalt, the Wanapum Basalt, and the Saddle Mountains Basalt. Only the Picture Gorge Basalt has not been found beneath the Hanford Site. The youngest basalt formations-

the Wanapum Basalt and the Saddle Mountains Basalt—have been subdivided into four and ten members, respectively. 


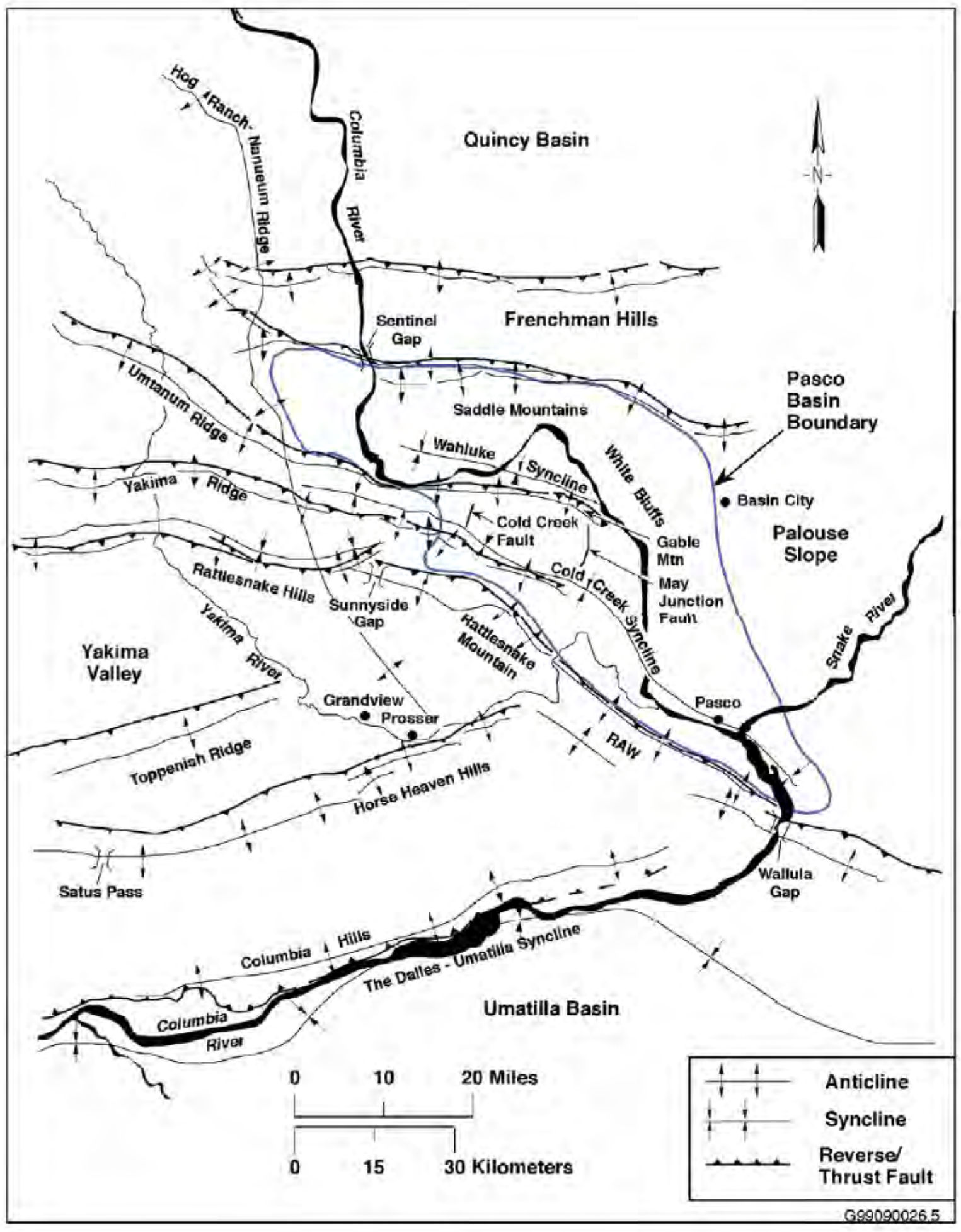

Figure 4.1. Main Structural Features of the Pasco Basin and Surrounding Area (after Reidel and Chamness 2007) 
The Wanapum and Saddle Mountains Basalts on the Hanford Site have been locally eroded to various degrees. Some erosion of the basalt occurred between eruptions, as well as before, during, and following deposition of the oldest Ringold Formation sediments. Uplift along anticlinal ridges has resulted in erosion to different depths along the margin of the Pasco Basin. North of the Central Plateau near Gable Gap, the Saddle Mountains Basalt has been locally eroded by fluvial activity and proglacial flooding down to its oldest member, the Umatilla Member.

\subsection{Deposition of the Ringold Formation}

Ancestral rivers draining south-central Washington were diverted by the rising anticlines and subsiding basins. Rivers progressively shifted courses into the structural and topographic lows of the Columbia Basin, eventually converging on the Pasco Basin (Swanson and Wright 1979; Fecht et al. 1987). The rivers deposited their sediment load of gravel, sand, silt, and clay in and adjacent to the major channelways (Newcomb et al. 1972; Tallman et al. 1981; Waitt and Swanson 1987; Lindsey 1996). These alluvial (river-deposited) sediments, together with volcanic ash, sidestream, and colluvial (landslide) debris, are interbedded with and overlie CRBG basalt flows. These sedimentary sequences are collectively referred to as the Ringold Formation (Newcomb et al. 1972). A diverse assemblage of fossils, paleomagnetic data, and reconstruction of the Columbia River indicate that the Ringold Formation was deposited between 3.4 and 10.5 million years ago (Gustafson 1978; Tallman et al. 1981; Fecht et al. 1987). Although the sedimentary record is incomplete, the sedimentation pattern is what would be expected in an area with limited rainfall and significant structural development (Fecht et al. 1987).

The coarse-grained sediments of the Ringold Formation were deposited in a fluvial environment associated with a through-flowing Columbia River system, whereas the fine-grained sediments represent a sluggish or impounded river system and lacustrine (lake) environments. These Ringold sediments were deposited within a subsiding Pasco Basin, where the rivers' hydraulic base levels were controlled by rising structural ridges or possibly temporary dams of lava in the Columbia River Gorge (Fecht et al. 1987; Waitt and Swanson 1987).

Lindsey (1995) identified five facies associations within the Ringold Formation and divided the Ringold into three informal members - the member of Wooded Island, the member of Taylor Flat, and the member of Savage Island (Lindsey 1995) — each dominated by different facies associations. Lindsey further subdivided the member of Wooded Island into five stratigraphic units, designated A, B, C, D, and E, dominated by fluvial gravel and separated by several widespread overbank/paleosol and lacustrine intervals.

The first record of the Columbia River at Hanford, after cessation of the Columbia River basalt volcanism, is the extensive gravel and interbedded sand of Unit A, Ringold Formation member of Wooded Island. This unit records the gravelly braid plain and paleosol system of the Columbia River that meandered across the Hanford Site, leaving the Pasco Basin through the present Yakima River water gap along the southeast end of the Rattlesnake Mountain anticline (Figure 4.1) (Fecht et al. 1987; Reidel et al. 1994; Lindsey 1995).

About 6.7 million years ago, the Columbia River abandoned this Yakima River water gap and began to exit the Pasco Basin via Wallula Gap (Figure 4.1). Its main channel was still through the Hanford Site; however, the depositional environment had changed to one of a sandy alluvial system with extensive 
lacustrine and overbank deposits (Fecht et al. 1987; Reidel et al. 1994; Lindsey 1995). A widespread lacustrine-overbank deposit called the lower mud was deposited over some of the Hanford Site at this time. The lower mud was then covered by another extensive sequence of fluvial gravels and sands. The most extensive of these is called Unit E, Ringold Formation member of Wooded Island, but locally other sequences are recognized (e.g., Units C and D). To the north near the 100 Areas, Ringold Formation sediments reflect mostly overbank deposition of fine-grained sediments during this time.

About 5 million years ago, the Columbia River sediments became more sand-dominated, and more than $90 \mathrm{~m}$ (295 ft) of interbedded fluvial sand and overbank deposits accumulated at Hanford. These deposits are collectively called the Ringold Formation member of Taylor Flat (Lindsey 1995). The fluvial sands of the member of Taylor Flat dominate the lower cliffs of the White Bluffs.

Between 4.8 and 3.4 million years ago, lacustrine deposits dominated Ringold Formation deposition. A series of three successive lakes is recognized along the White Bluffs and elsewhere along the margin of the Pasco Basin (Lindsey 1995). The lakes probably resulted from damming of the Columbia River farther downstream, possibly in the Columbia Gorge. The lacustrine and related deposits in the Pasco Basin are collectively called the Ringold Formation member of Savage Island.

\subsection{Incision of the Ringold Formation and Deposition of Isolated Cold Creek Unit Deposits}

About 3.4 million years ago, western North America underwent regional uplift, resulting in a major drop in the hydraulic base level for the ancestral Columbia River system and an end to deposition of Ringold sediments. The base level change resulted in regional erosion and downcutting causing the ancestral rivers to incise deeply into the Ringold Formation, removing nearly $100 \mathrm{~m}$ of Ringold Formation sediments from the Hanford Site. As incision progressed eastward across Hanford, more and more erosion occurred, leaving surface elevation changes in the Ringold Formation and culminating in maximum erosion near the current river channel. In some places, erosion cut completely through the Ringold to the top of basalt.

During and immediately following the downcutting period, the basin reached a temporary base level, and alluvial sediments and windblown loess began depositing in lower elevations of the basin. In addition, thick calcic paleosols developed across extensive parts of the area due to the arid climate. The sediments and paleosols are superimposed disconformably on the erosional surface of the Ringold Formation. Alluvial gravel, sand, and silt deposits accumulated along the channelways of the ancestral river system. In places, these coarse-grained clastic sediments are referred to as pre-Missoula gravels (PSPL 1981). On the basin margins, sidestreams were actively eroding rocks and sediments from the emerging ridges and depositing gravel (mainly basalt clasts), sand, and silt into ancestral sidestreams such as in the Cold Creek and Dry Creek valleys. The deposits, sandwiched between the Ringold Formation and the overlying Hanford formation, are locally referred to on the Hanford Site as the Cold Creek Unit (DOE 2002).

\subsection{Ice Age Flooding and Deposition of the Hanford formation}

With the onset of the last major Ice Age some 2.6 million years ago, cataclysmic floods (including the Missoula floods) repeatedly inundated the Pasco Basin, depositing a thick sequence of sediment 
informally called the Hanford formation (Baker et al. 1991; DOE 2002; Bjornstad 2006). These huge floods (some containing more than $500 \mathrm{mi}^{3}$ of water) occurred when ice dams failed, releasing large volumes of water from ice marginal lakes (e.g., glacial Lake Missoula). These outburst floods occurred repeatedly during regular glacial cycles. The largest of these floods had flow rates up to about 17 million cubic meters per second, ten times the combined flow rate of all the modern rivers of the world, making them arguably the largest recorded floods known to have occurred on Earth (O'Conner and Costa 2004). In addition to larger major flood episodes, numerous smaller individual flood events are also likely to have occurred. As many as 100 separate flood events have been postulated to have occurred during the last glacial cycle alone, 15,000 to 20,000 years ago (Waitt 1994). Deciphering the history of cataclysmic flooding in the Pasco Basin is complicated, not only because of floods from multiple sources but also because the paths of Missoula floodwaters migrated and changed course with the advance and retreat of the Cordilleran Ice Sheet. Recent studies using paleomagnetic signatures in fine-grained sediments of the Hanford formation suggest that the earliest floods may have occurred as early as 2 million years ago. Pluhar et al. (2006) found four magnetic polarity reversals preserved in Hanford formation sediment. The uppermost reversed paleomagnetic signatures suggest that some cataclysmic floods exceed 780,000 years ago (Baker et al. 1991; Pluhar et al. 2006). Radiometric age dating using thorium and uranium has put other flood deposits at 200,000 to 220,000 years old (Baker et al. 1991).

Along with sedimentological evidence for cataclysmic flooding in the Pasco Basin, high-water marks and faint strandlines occur along the basin margins. Temporary ponding of the Ice Age floodwaters behind Wallula Gap created the short-lived Lake Lewis and left behind ice-rafted erratic boulders and mounds of iceberg debris (berg mounds) as well as fossils of mammoths and other creatures caught up in the floods (Barton 1999; Bjornstad 2006). High watermark elevations for Lake Lewis, inferred from icerafted erratics on ridges, range from 370 to $385 \mathrm{~m}$ (1,214 to 1,261 ft) above sea level (Reidel and Chamness 2007).

The sediment deposited by the cataclysmic floodwaters has been informally called the Hanford formation. Gravel-dominated sediments are generally confined to relatively narrow tracts within or near flood channelways. Sand-dominated sediments, on the other hand, occur primarily as a broad sheet over most of the central basin. Paleocurrent indicators within the plane-laminated sand facies (DOE 2002) generally indicate flow toward the south and east within the Pasco Basin. Sediments dominated by interbedded silt and sand rhythmites occur in slackwater areas around the margins of the basin and display multidirectional currents, including upvalley currents, and generally seem to become finer and thinner both laterally and vertically.

\subsection{Holocene Deposits}

After the last Ice Age flood drained from the Pasco Basin, winds moved the loose, unconsolidated material until vegetation was able to stabilize it. Stabilized sand dunes cover much of the Pasco Basin, but there are areas, such as along the Hanford Reach National Monument, where sand dunes remain active. Locally, fluvial and colluvial processes also have shaped the landscape and deposited locally derived sediments. 


\subsection{Stratigraphic Contacts Beneath the Central Plateau}

This section describes the methodology used to compile and integrate available information on the vertical location of stratigraphic contacts that define the tops of major stratigraphic units (e.g., formations, members, and mappable facies associations) beneath the Central Plateau. The resulting updated and revised database is intended to be used to 1) update and revise a solid model of the geology beneath the 200 West Area and, subsequently, the 200 East Area; 2) provide an a priori data set with which to evaluate areas of high uncertainty or disagreement; and 3) identify and prioritize boreholes for detailed evaluation to resolve those discrepancies and reach agreement on the best-estimate contact locations.

The primary methodology was to 1) build on the existing database compiled by Bjornstad (2004), 2) convert it from a computed elevation-based database to a depth-below-ground-surface database, 3) update it with additional documented geologic contact information (e.g., from Reidel and Chamness 2007), 4) verify and evaluate the various contact data sets, and 5) select best-estimate contact values to be used in the a priori geologic model of the 200 West Area.

Some of the main concerns or sources of error among various documented contact elevation data sets have been differences in stratigraphic nomenclature, the ground-surface elevations used to calculate the contact elevations, and rounding errors introduced in conversion from contact depths in feet below ground surface to elevation in meters or, in some cases, conversion from elevations in meters to depths in feet. Thus, our approach was to compile previously documented stratigraphic contacts in terms of depth in feet below ground surface so as to improve traceability back to the raw borehole data collected at the time of drilling. Previously documented elevation-based data sets have been developed by subtracting the interpreted depth of geologic contacts from surveyed or estimated ground-surface elevations (presumably at the time of drilling) for each particular borehole. However, the quality of ground-surface elevation data and reference datum has varied over time, and some repeat estimates have been shown to vary by as much as a meter. Thus, for each documented source of contact elevation information, the reported contact elevations were subtracted from the reported ground-surface elevation to yield the previous investigators' working contact depths.

To support update and revision of the geologic model for the 200 West Area, the best-estimate contact depths (in feet below ground surface) need to be converted to elevations (in meters above mean sea level). To support this effort, a best-estimate ground-surface elevation database (representing the ground surface at the time of drilling) was developed based on vertical survey and well construction data extracted from the Hanford Well Information System (HWIS) and a set of logic rules.

This section describes the stratigraphic nomenclature (and assumed correlations to previous nomenclature) used in this study, as well as the efforts made to develop the stratigraphic contact depths database and the best-estimate ground-surface elevation database.

\subsection{Stratigraphic Nomenclature}

Stratigraphic nomenclature has historically varied by project and principal investigator, so it is difficult to directly relate the documented and undocumented geologic contacts to one another. However, Bjornstad (2004) evaluated the various sources of contact information and translated them into 12 main stratigraphic units that could be correlated over most of the 200 Areas. These units were based on the 
standardized stratigraphic nomenclature for post-Ringold sediments defined by DOE (2002) and in part on the Hanford formation subdivisions (H1, H2, and so on) identified by Lindsey et al. (1994, 2000, 2001) and Wood et al. (2000). The nomenclature for units within the Ringold Formation was based on that defined by Lindsey (1995).

Although Lindsey et al. (2000, 2001) and Wood et al. (2000) used similar subdivisions within the Hanford formation in both the 200 East Area and 200 West Area, paleomagnetic polarity data indicate that the subdivisions in the 200 East Area are not necessarily time correlative with those in the 200 West Area (Pluhar et al. 2006). Thus, they do not represent the same sedimentary sequences (Reidel and Chamness 2007). Discrete sedimentary packages from individual flood events, particularly within the coarser facies associations of the Hanford formation have only been recognized in excavations (e.g., 218-E-12b burial ground, Pit \#30, U.S. Ecology, Environmental Restoration Disposal Facility, Fuels and Materials Examination Facility) and are yet to be recognized from borehole samples alone. For all intents and purposes, the coarse facies associations within the Hanford formation appear to be completely interbedded and display considerable lateral as well as vertical facies variations. Nevertheless, we have chosen to use the following general nomenclature- upper coarse-dominated (H1), sand-dominated (H2), and lower coarse-dominated (H3) to represent the main subdivisions of the Hanford formation in the 200 West Area.

Table 5.1 provides a brief description of the stratigraphic units used in this report. Figure 5.1 illustrates how the nomenclature used by different investigators compares with the nomenclature selected for this compilation of geologic contacts.

\subsection{Stratigraphic Contact Data}

Stratigraphic contact data (Appendix A) were compiled from published reports in addition to some unpublished data (Table 5.2). Over 1,190 records were compiled for 446 different boreholes located in and around the 200 West Area (Figure 5.2). The source used as the basis for the vertical location of stratigraphic contacts for each borehole was included in this compilation (see Appendix A). In many cases, published contact information has been presented in terms of the elevation, in feet above mean sea level, of the top of a specific stratigraphic unit (e.g., Last et al. 1989; Rohay et al. 1994; Reidel and Chamness 2007). Often, these published contact elevations have been rounded to the nearest foot. To convert these contact elevations to depth below ground surface, the reported contact elevation was subtracted from the reported ground-surface elevation. Where metric data are presented (e.g., Last et al. 2006; Oostrom et al. 2006; Thorne et al. 2006), the contact elevations (in meters) were first converted to feet (using a conversion factor of $0.3048 \mathrm{~m} / \mathrm{ft}$ (Thompson and Taylor 2008); $3.28084 \mathrm{ft} / \mathrm{m}$ ) and then the contact depths were calculated. Where contact data were reported as depth in feet (e.g., Bjornstad 1984; Last et al. 1989; Serne et al. 2004a, 2004b), the contact data were taken directly. Unpublished data were generally assigned a low priority but were used where published data for a given well and contact were unavailable or were considered an improvement over the previously published contacts. A brief description of the published data sources, and how they were used to derive the contact depths compiled in this report, is provided in Table 5.2. 
Table 5.1. Stratigraphic Nomenclature and Symbols Used in This Report

\begin{tabular}{|c|c|}
\hline $\begin{array}{l}\text { Stratigraphy Unit (symbol) } \\
\text { Used in This Report }\end{array}$ & $\begin{array}{c}\text { Descriptions Summarized from DOE (2002), Lindsey et al. (1994), Lindsey (1995), } \\
\text { Lindsey et al. (2000), and Reidel and Chamness (2007) }\end{array}$ \\
\hline Backfill (Bf) & $\begin{array}{l}\text { Poorly sorted, massive, gravel, sand, and silt removed from and subsequently returned } \\
\text { to excavations. }\end{array}$ \\
\hline $\begin{array}{l}\text { Holocene deposits, sand } \\
\text { (HDs) }\end{array}$ & $\begin{array}{l}\text { Medium to fine-grained massive to weakly laminated eolian sand to silty sand, } \\
\text { equivalent to the fine-grained, massive, well-sorted and medium-grained cross- } \\
\text { bedded, well-sorted Holocene deposits described by DOE (2002). }\end{array}$ \\
\hline $\begin{array}{l}\text { Hanford formation Unit } 1 \\
\text { (HF1) }\end{array}$ & $\begin{array}{l}\text { Upper gravel-dominated sequence, consisting of high-energy Ice Age flood deposits, } \\
\text { which in places grades upward into a mix of sandy and gravelly sediments. Generally } \\
\text { contains a high percentage of subangular basaltic clasts. Equivalent to Lindsey et al. } \\
\text { (2000) Unit H1a and Unit H1. }\end{array}$ \\
\hline $\begin{array}{l}\text { Hanford formation Unit } 2 \\
\text { (HF2) }\end{array}$ & $\begin{array}{l}\text { Middle sand-dominated sequence, consisting of moderate- to high-energy Ice Age } \\
\text { flood deposits consisting of graded sandy and silty sediments often characterized as } \\
\text { basaltic, salt-and-pepper sand. Equivalent to Lindsey et al. (2000) Unit H2. }\end{array}$ \\
\hline $\begin{array}{l}\text { Hanford formation Unit } 3 \\
\text { (HF3) }\end{array}$ & $\begin{array}{l}\text { Lower gravel-dominated sequence, consisting of high-energy Ice Age flood deposits } \\
\text { containing a high percentage of subangular basaltic clasts, equivalent to Unit } 3 \text { of } \\
\text { Lindsey et al. (1994) and Unit H3 of Lindsey et al. (2000). The base of this unit } \\
\text { includes some fine-grained materials equivalent to Lindsey et al. (2000) Unit H4. }\end{array}$ \\
\hline $\begin{array}{l}\text { Cold Creek Unit silt } \\
\text { (CCUz) }\end{array}$ & $\begin{array}{l}\text { Fine sand, silt, and/or clay, laminated to massive, often characterized as very } \\
\text { micaceous, oxidized, and containing pedogenic calcium carbonate, with high natural } \\
\text { gamma activity. It is equivalent to the early Palouse Soil of Brown }(1959,1960) \text {, a } \\
\text { portion of the "locally derived subunit” of the Plio-Pleistocene Unit of Lindsey et al. } \\
\text { (1994), and the fine-grained, laminated to massive facies association of the Cold } \\
\text { Creek Unit of DOE (2002). }\end{array}$ \\
\hline $\begin{array}{l}\text { Cold Creek Unit carbonate } \\
\text { (CCUc) }\end{array}$ & $\begin{array}{l}\text { Pedogenic calcium carbonate cemented clay, silt, sand, and/or gravel, equivalent to } \\
\text { the Caliche of Brown (1959, 1960), a portion of the "locally derived subunit” of the } \\
\text { Plio-Pleistocene Unit of Lindsey et al. (1994) and the coarse- to fine-grained, } \\
\text { carbonate-cemented facies association of the Cold Creek Unit of DOE (2002). }\end{array}$ \\
\hline $\begin{array}{l}\text { Ringold Formation } \\
\text { Member of Taylor Flat } \\
\text { (Rtf) }\end{array}$ & Interstratified deposits of fine-grained fluvial sand and silt deposits. \\
\hline $\begin{array}{l}\text { Ringold Formation } \\
\text { Member of Wooded Island } \\
\text { - Unit E (Rwie) }\end{array}$ & $\begin{array}{l}\text { Well-rounded fluvial gravel of mixed lithologies, in a sand and silt matrix. } \\
\text { Cementation varies from well to poorly indurated. }\end{array}$ \\
\hline $\begin{array}{l}\text { Ringold Formation - lower } \\
\text { mud (Rlm) }\end{array}$ & $\begin{array}{l}\text { Primarily consists of lacustrine silt and clay, overlying a well-developed paleosol } \\
\text { noted beneath } 200 \text { West Area. }\end{array}$ \\
\hline $\begin{array}{l}\text { Ringold Formation } \\
\text { Member of Wooded Island } \\
\text { - Unit A (Rwia) }\end{array}$ & $\begin{array}{l}\text { Similar to Unit E (Rwie). Generally described as a conglomerate with clasts of basalt } \\
\text { and other lithologies in a silty sand matrix intercalated with beds of sand and silt. The } \\
\text { sediments are strongly cemented with silica or calcite in places. }\end{array}$ \\
\hline $\begin{array}{l}\text { Saddle Mountains Basalt } \\
\text { Formation, Elephant } \\
\text { Mountain Member (Tem) }\end{array}$ & Tholeiitic flood-basalt of the Elephant Mountain Member. \\
\hline
\end{tabular}




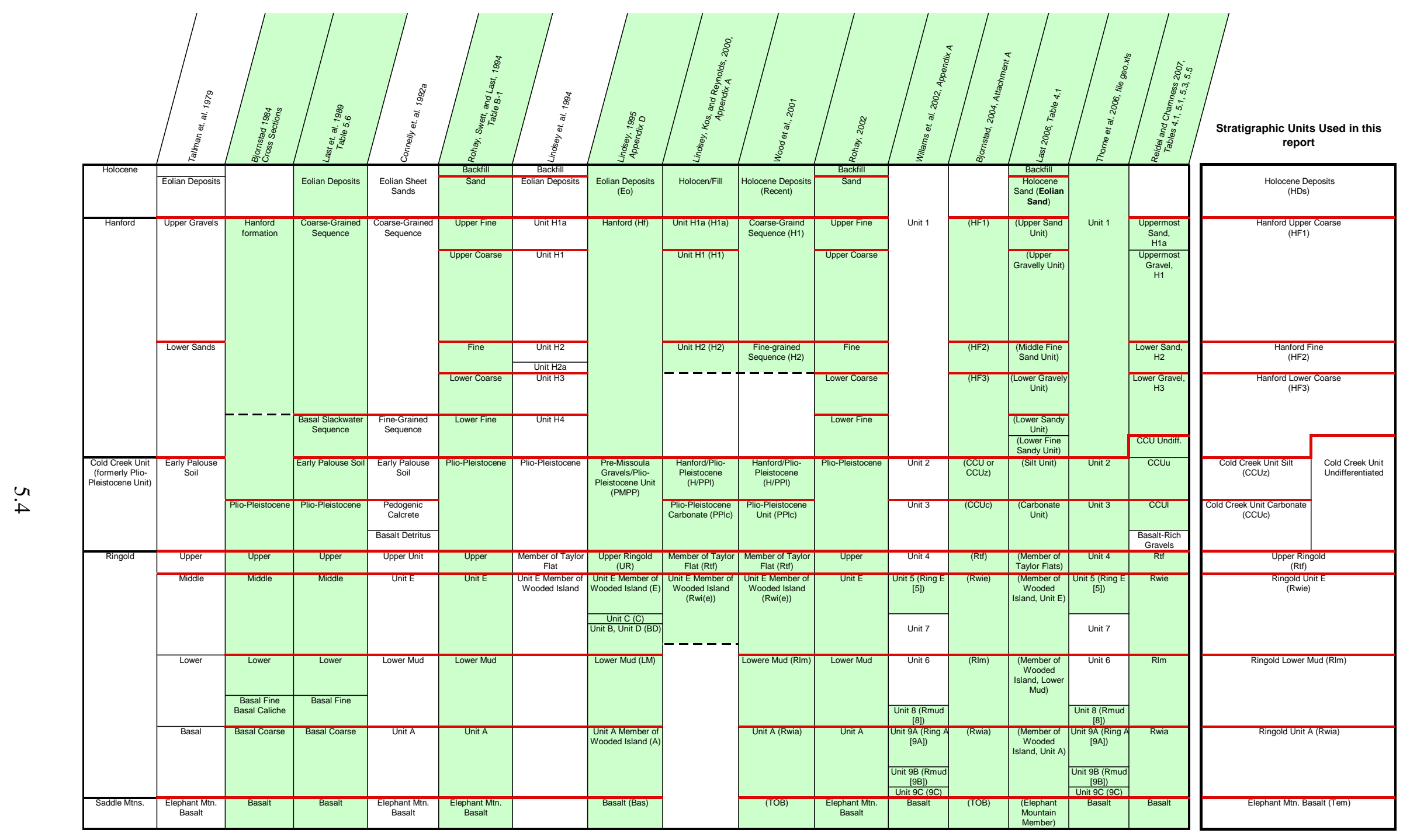

Figure 5.1. Correlation of Stratigraphic Units Used by Different Investigators to Those Used in This Report 
Table 5.2. Sources of Stratigraphic Contacts Data for the 200 West Area

\begin{tabular}{|c|c|c|c|}
\hline Reference & $\begin{array}{l}\text { Symbol } \\
\text { Used in } \\
\text { Database }\end{array}$ & $\begin{array}{l}\text { Rank/ } \\
\text { Priority }\end{array}$ & Comments \\
\hline $\begin{array}{l}\text { Bjornstad } \\
\text { (1984, cross } \\
\text { sections) }\end{array}$ & Bjornstad84 & 2 & $\begin{array}{l}\text { Stratigraphic contacts in depth in feet (and meters) were identified on } \\
\text { geologic cross sections. Holocene, Hanford formation, and Cold } \\
\text { Creek Unit silt deposits were undifferentiated. The lower Ringold } \\
\text { Unit was differentiated from a basal unit, consisting of basal fine, } \\
\text { basal caliche, and basalt gravel subunits. Note that for this report, the } \\
\text { lower Ringold, basalt fine, and basal caliche units were grouped } \\
\text { together as the Ringold lower mud unit. }\end{array}$ \\
\hline $\begin{array}{l}\text { Last et al. } \\
\text { (1989, } \\
\text { Table 5.6) }\end{array}$ & Last89 & 1 & $\begin{array}{l}\text { Stratigraphic contacts for the } 200 \text { West Area were tabulated (in } \\
\text { Table 5.6, p. 5.61) in depth in feet (and elevation in feet) and shown } \\
\text { on borehole summary logs. Note that the depth-in-feet values were } \\
\text { used for this report, and that Holocene and Hanford formation } \\
\text { deposits were left undifferentiated. }\end{array}$ \\
\hline $\begin{array}{l}\text { Rohay (1994, } \\
\text { Table B-1) }\end{array}$ & Rohay94 & 2 & $\begin{array}{l}\text { Geologic contacts were tabulated in elevation in feet and shown on } \\
\text { geologic cross sections, structure-contour maps, and isopach maps. } \\
\text { Contact depths for this report were derived by subtracting the contact } \\
\text { elevation from the reported ground-surface elevation. Holocene } \\
\text { deposits of backfill and sand were reported separately but for this } \\
\text { report were grouped together. The Hanford formation was subdivided } \\
\text { into five textural subunits, which for this report were mapped to the } \\
\text { H1, H2, and H3 units (see Figure 5.1). The Plio-Pleistocene Unit was } \\
\text { not subdivided; however, for this report, the top of this unit is } \\
\text { interpreted to be equivalent to the Cold Creek Unit silt. }\end{array}$ \\
\hline $\begin{array}{l}\text { Lindsey (1995, } \\
\text { Appendix D) }\end{array}$ & Lindsey95 & 2 & $\begin{array}{l}\text { Contact elevations were tabulated in feet and represented on geologic } \\
\text { cross sections, structure-contour maps, and isopach maps. Contact } \\
\text { depths for this report were derived by subtracting the contact } \\
\text { elevation from the reported ground-surface elevation. Holocene } \\
\text { deposits were not differentiated and neither were the Hanford } \\
\text { formation or Pre-Missoula/Plio-Pleistocene deposits. A number of } \\
\text { sub-units (e.g., Sub E) were called out within larger units (e.g., } \\
\text { Unit E) of the Ringold Formation; however, only the top contact for } \\
\text { the larger units was used in this report. }\end{array}$ \\
\hline $\begin{array}{l}\text { Lindsey et al. } \\
\text { (2000, } \\
\text { Appendix A) }\end{array}$ & Lindsey00 & 1 & $\begin{array}{l}\text { Contact elevations were reported in feet and shown on summary } \\
\text { borehole logs and geologic cross sections. Contact depths for this } \\
\text { report were derived by subtracting the contact elevation from the } \\
\text { reported ground-surface elevation. Note that Units H1a and H1 were } \\
\text { grouped together for this report. Also note that contacts for Hanford } \\
\text { Unit H3 were not reported and that the reported values for the } \\
\text { Hanford/Plio-Pleistocene Unit are used here to represent the Cold } \\
\text { Creek Unit silt. }\end{array}$ \\
\hline $\begin{array}{l}\text { Wood et al. } \\
\text { (2001, } \\
\text { Table 2-2) }\end{array}$ & Wood01 & 1 & $\begin{array}{l}\text { Contact elevations were reported in feet. Contact depths for this } \\
\text { report were derived by subtracting the contact elevation from the } \\
\text { reported ground-surface elevation. Note that contacts for Hanford } \\
\text { Unit H3 were not reported and that the reported values for Hanford/ } \\
\text { Plio-Pleistocene are used here to represent the Cold Creek Unit silt. }\end{array}$ \\
\hline
\end{tabular}


Table 5.2. (contd)

\begin{tabular}{|c|c|c|c|}
\hline Reference & $\begin{array}{l}\text { Symbol } \\
\text { Used in } \\
\text { Database }\end{array}$ & $\begin{array}{l}\text { Rank/ } \\
\text { Priority }\end{array}$ & Comments \\
\hline $\begin{array}{l}\text { Serne et al. } \\
\text { (2002a, } \\
\text { Figures 2.18 } \\
\text { and 2.19) }\end{array}$ & $\begin{array}{l}\text { PNNL- } \\
13757-1\end{array}$ & 1 & $\begin{array}{l}\text { Contacts depths for the 299-W22-48 and 299-W22-50 boreholes were } \\
\text { reported on borehole summary logs (Figures } 2.18 \text { and 2.19). }\end{array}$ \\
\hline $\begin{array}{l}\text { Serne et al. } \\
\text { (2002d, } \\
\text { Figure } 2.2 \\
\text { [and text], and }\end{array}$ & $\begin{array}{l}\text { PNNL- } \\
13757-2\end{array}$ & 1 & $\begin{array}{l}\text { Contacts depths for the 299-W23-19 borehole were reported in feet on a } \\
\text { borehole summary log (Figure 2.2) and within the text (pp. } 2.6 \text { through } \\
\text { 2.10). }\end{array}$ \\
\hline Figure 2.3) & & 2 & $\begin{array}{l}\text { Contact depths were reported in feet for selected boreholes along a } \\
\text { southwest-to-northeast cross section (Figure 2.3). }\end{array}$ \\
\hline $\begin{array}{l}\text { Serne et al. } \\
(2002 b \text {, } \\
\text { Figure } 2.6 \text { and } \\
\text { text, and }\end{array}$ & $\begin{array}{l}\text { PNNL- } \\
13757-3\end{array}$ & 1 & $\begin{array}{l}\text { Contacts depths for the 299-W23-234 (410-09-39) borehole were } \\
\text { illustrated in a borehole summary log (Figure 2.6) and reported in feet } \\
\text { within the text (pp. } 2.7 \text { through 2.15). Some interpretation was } \\
\text { necessary to calculate depths from thicknesses. }\end{array}$ \\
\hline $\begin{array}{l}\text { Figures } 2.3 \\
\text { and } 2.4)\end{array}$ & & 2 & $\begin{array}{l}\text { Contact depths were reported in feet for selected boreholes along two } \\
\text { cross sections (Figures } 2.3 \text { and 2.4). }\end{array}$ \\
\hline $\begin{array}{l}\text { Serne et al. } \\
(2002 c \text {, } \\
\text { Figure } 2.9 \text { and } \\
\text { text, and }\end{array}$ & $\begin{array}{l}\text { PNNL- } \\
13757-4\end{array}$ & 1 & $\begin{array}{l}\text { Contacts depths for borehole C3082 (slant borehole) were illustrated } \\
\text { in a borehole summary log (Figure 2.9) and reported in feet within the } \\
\text { text (pp. } 2.15 \text { through 2.21). }\end{array}$ \\
\hline Figure 2.5) & & 2 & $\begin{array}{l}\text { Contact depths were reported in feet for selected boreholes along a } \\
\text { northwest-to-southeast cross section (Figure 2.5). }\end{array}$ \\
\hline $\begin{array}{l}\text { Williams et al. } \\
\text { (2002, } \\
\text { Appendix A) }\end{array}$ & Williams02 & 1 & $\begin{array}{l}\text { Contact elevations were reported in feet. Contact depths for this } \\
\text { report were derived by subtracting the contact elevation from the } \\
\text { reported ground-surface elevation. Note that no strata above the top } \\
\text { of the Ringold Unit E were differentiated and that Ringold A Units } \\
\text { 9A, 9B, and 9C were grouped together for this report. Note also that } \\
\text { contact values listed as “0," "NDE,” "ND,” or “*” were assumed to } \\
\text { represent undetermined values and were left blank. Contact } \\
\text { elevations reported as "greater than” or "less than” were also left } \\
\text { blank. }\end{array}$ \\
\hline $\begin{array}{l}\text { Serne et al. } \\
\text { (2004a, } \\
\text { Figures } 2.5\end{array}$ & Serne04a & 1 & $\begin{array}{l}\text { Contacts depths for the subject boreholes were reported in feet within } \\
\text { the text (pp. 2-21 through 2-53). }\end{array}$ \\
\hline $\begin{array}{l}\text { and } 2.6 \text { and } \\
\text { text) }\end{array}$ & & 3 & $\begin{array}{l}\text { Contact depths, in feet, were reported on cross sections A-A' and } \\
\text { B-B' (Figures } 2.5 \text { and 2.6), apparently reproduced or modified from } \\
\text { Wood et al. (2001). }\end{array}$ \\
\hline $\begin{array}{l}\text { Serne et al. } \\
\text { (2004b, } \\
\text { Figures } 2.5\end{array}$ & Serne04b & 1 & $\begin{array}{l}\text { Contacts depths for the subject boreholes were also reported in feet } \\
\text { within the text (pp. 2-22 through 2-50). }\end{array}$ \\
\hline $\begin{array}{l}\text { and } 2.6 \text { and } \\
\text { text) }\end{array}$ & & 3 & $\begin{array}{l}\text { Contact depths, in feet, were reported on cross sections A-A' and } \\
\text { B-B' (Figures } 2.5 \text { and 2.6), apparently reproduced or modified from } \\
\text { Wood et al. (2001). }\end{array}$ \\
\hline
\end{tabular}


Table 5.2. (contd)

\begin{tabular}{|c|c|c|c|}
\hline Reference & $\begin{array}{l}\text { Symbol } \\
\text { Used in } \\
\text { Database }\end{array}$ & $\begin{array}{l}\text { Rank/ } \\
\text { Priority }\end{array}$ & Comments \\
\hline $\begin{array}{l}\text { Last et al. } \\
\text { (2006, } \\
\text { Table 4.1, } \\
\text { Appendix B) }\end{array}$ & Last06 & 1 & $\begin{array}{l}\text { Best-estimate ground-surface and contact elevations were tabulated in } \\
\text { meters. Contact elevations in feet were shown on detailed logplots. } \\
\text { Contact depths for this report were derived by subtracting the contact } \\
\text { elevation (in meters) from the reported ground-surface elevation (in } \\
\text { meters) and then converting to depth. Note that the Holocene } \\
\text { deposits of backfill and eolian sand were grouped together for this } \\
\text { report. Note also that the upper sand unit and upper gravelly unit } \\
\text { were grouped together as representing the H1 Unit; the middle fine } \\
\text { sand unit was taken as equivalent to the H2 Unit; and the lower } \\
\text { gravelly unit, lower sandy unit, and lower fine sandy unit were } \\
\text { grouped together as representing the H3 Unit. Note also that the } \\
\text { borehole data for wells 299-W18-6 and W18-7 were found to have } \\
\text { been reversed and corrected, as noted on the logplots. }\end{array}$ \\
\hline $\begin{array}{l}\text { Oostrom et al. } \\
\text { (2006, } \\
\text { Table 3.2) }\end{array}$ & Oostrom06 & $\begin{array}{l}3, \\
2\end{array}$ & $\begin{array}{l}\text { Contact elevations were tabulated in meters, modified from Last et al. } \\
\text { (2006). Selected contacts are also displayed on geologic cross } \\
\text { sections. This source was not used to derive contact depths. }\end{array}$ \\
\hline $\begin{array}{l}\text { Thorne et al. } \\
\text { (2006, geo.xls) }\end{array}$ & Thorne06 & 3 & $\begin{array}{l}\text { Contact elevations were tabulated in meters, based on the NGVD29 } \\
\text { elevation datum. Ground surface was not explicitly reported; } \\
\text { however, the top of Unit } 1 \text { was taken as ground surface. Contact } \\
\text { elevations in meters were then converted to feet using a conversion of } \\
3.28084 \mathrm{ft} / \mathrm{m} \text {. Contact depths for this report (in feet) were derived by } \\
\text { subtracting the contact elevation (in feet) from the ground-surface } \\
\text { (top of Unit } 1 \text { ) elevation (in feet). Note that Holocene and Hanford } \\
\text { formation units were undifferentiated. Note also that for this report, } \\
\text { Unit } 6 \text { was grouped with Unit } 8 \text { and Unit } 7 \text { was grouped with Unit } 5 \text {. }\end{array}$ \\
\hline $\begin{array}{l}\text { Reidel and } \\
\text { Chamness } \\
\text { (2007, } \\
\text { Tables 4.1, } \\
\text { 5.1, 5.3, and } \\
5.5)\end{array}$ & Reidel07 & 3 & $\begin{array}{l}\text { Contact elevations were reported in feet, and selected contacts were } \\
\text { illustrated on cross sections. Much of this appears to be taken or } \\
\text { modified from other documents (e.g., Wood et al. 2001). Contact } \\
\text { depths for this report were derived by subtracting the contact } \\
\text { elevation from the reported ground-surface elevation. Note that } \\
\text { undifferentiated Holocene deposits were not specifically called out } \\
\text { but were assumed to be the same as the ground-surface elevation. } \\
\text { Note also that the H1a and H1 units were grouped together for this } \\
\text { report and that the "Post Ringold Basalt-Rich Gravels" identified in } \\
\text { Table 4.1were not explicitly identified in this report. }\end{array}$ \\
\hline $\begin{array}{l}\text { Jeppson } \\
\left(2007^{(1)}\right. \\
\text { Table 1) }\end{array}$ & Jeppson07 & 4 & $\begin{array}{l}\text { Bottom contact elevations and depths were reported in meters, and } \\
\text { selected contacts were illustrated on a cross section in Figure } 4 . \\
\text { Logplots are provided in Appendix A without contacts. Contact } \\
\text { depths in feet were converted from the depth in meters. }\end{array}$ \\
\hline $\begin{array}{l}\text { Sexton (2008; } \\
\text { SGW-37703, } \\
\text { DRAFT) }\end{array}$ & Sexton08 & 2 & $\begin{array}{l}\text { Contact depths were reported in feet. Section } 3 \text { contains a brief } \\
\text { summary of the borehole stratigraphy for wells } 299-W 11-88,699-43- \\
69 \text {, and } 699-45-69 \text { C. Interpretations of the geology were based on } \\
\text { analysis of borehole logs in addition to firsthand observation by J. A. } \\
\text { Horner, during the drilling of borehole 699-43-69. }\end{array}$ \\
\hline
\end{tabular}

\footnotetext{
${ }^{1}$ Jeppson TN. 2007. Heterogeneity of Aquifer Materials and Spatial Variability in the Carbon Tetrachloride Plume in the 200-West Area, Hanford Site. Science Undergraduate Laboratory Internship (SULI) Report. Pacific Northwest National Laboratory, Richland, Washington.
} 
Table 5.2. (contd)

\begin{tabular}{|c|c|c|c|}
\hline Reference & $\begin{array}{l}\text { Symbol } \\
\text { Used in } \\
\text { Database }\end{array}$ & $\begin{array}{l}\text { Rank/ } \\
\text { Priority }\end{array}$ & Comments \\
\hline $\begin{array}{l}\text { Williams } \\
\text { (unpublished) }\end{array}$ & Williams08 & 4,5 & $\begin{array}{l}\text { Contact depths and elevations were reported in feet. The upper } \\
\text { Ringold (Rtf) and Unit E (Rwie) were undifferentiated with the } \\
\text { undifferentiated Ringold contact reported as Rtf. Contact depths were } \\
\text { taken directly as reported (personal communication via email from } \\
\text { B. A. Williams dated March 5, 2008). This source was used only for } \\
\text { indication purposes and where no other published data were available. }\end{array}$ \\
\hline $\begin{array}{l}\text { Last } \\
\text { (unpublished) }\end{array}$ & Last & 4,5 & $\begin{array}{l}\text { The date and pedigree of these unpublished data are uncertain. Both } \\
\text { contact elevations and depths were provided in feet. This source was } \\
\text { used only for indication purposes and where no other published data } \\
\text { were available. }\end{array}$ \\
\hline $\begin{array}{l}\text { Thorne } \\
\text { (unpublished) }\end{array}$ & Thorne & 4,5 & $\begin{array}{l}\text { The date and pedigree of these unpublished data are uncertain. Both } \\
\text { contact elevations and depths were provided in feet. This source was } \\
\text { used only for indication purposes and where no other published data } \\
\text { were available. }\end{array}$ \\
\hline $\begin{array}{l}\text { Bjornsta } \\
\text { report) }\end{array}$ & Bjornstad08 & Unranked & $\begin{array}{l}\text { Best-estimate contact elevations were provided in feet as an update to } \\
\text { the geologic contacts data published by Bjornstad in } 2004 \text {. These } \\
\text { values were based on one or more records from other sources, often } \\
\text { with some correction to account for differences in ground-surface } \\
\text { elevation. The recorded best-estimate picks were taken from a } \\
\text { spreadsheet provided via email from B. N. Bjornstad on January 16, } \\
2008 \text {. }\end{array}$ \\
\hline $\begin{array}{l}\text { Last (this } \\
\text { report) }\end{array}$ & Last08 & Unranked & $\begin{array}{l}\text { Best-estimate contact depths in feet were selected for this report based } \\
\text { primarily on a combination of records from other sources. }\end{array}$ \\
\hline $\begin{array}{l}\text { Horner (this } \\
\text { report) }\end{array}$ & Horner08 & Unranked & $\begin{array}{l}\text { Jontact depths in feet were selected for some new } \\
\text { rovide some new interpretations influenced by cr } \\
\text { nalyses. }\end{array}$ \\
\hline \multicolumn{4}{|c|}{$\begin{array}{l}1 \text { - Reported contacts are directly traceable to raw borehole data (e.g., through summary logs with contacts) and } \\
\text { firsthand geologic interpretation (e.g., cross sections, structure contour maps). } \\
2 \text { - Reported contacts are indirectly traceable to raw borehole data (i.e., no summary logs) but are represented in } \\
\text { firsthand geologic interpretation. }\end{array}$} \\
\hline \multicolumn{4}{|c|}{$\begin{array}{l}3 \text { - Reported contacts are not readily traced to raw borehole data or firsthand geologic interpretation (e.g., data } \\
\text { and/or interpretations taken from other documents). }\end{array}$} \\
\hline \multicolumn{4}{|c|}{$\begin{array}{l}4 \text { - Unpublished contact data where no other data are available from that principal investigator(s). } \\
5 \text { - Unpublished contact data that has been superseded by other published data by the same principal } \\
\text { investigator(s). }\end{array}$} \\
\hline \multicolumn{4}{|c|}{ Note: Contact data developed for this report were not assigned a rank. } \\
\hline
\end{tabular}




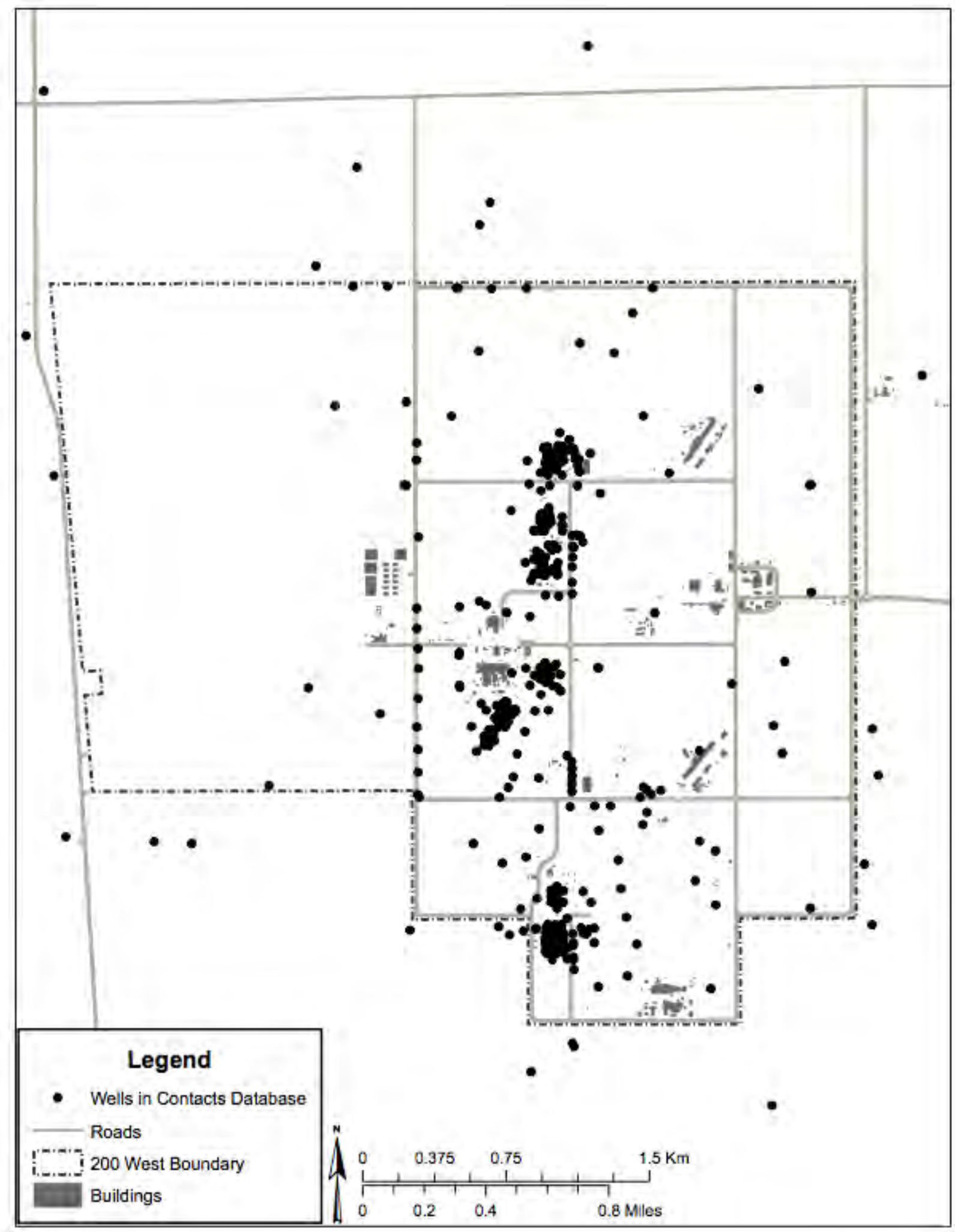

Figure 5.2. Location of Boreholes in and Adjacent to the 200 West Area, with Stratigraphic Contact Data 
In keeping with the approach used by Bjornstad (2004), where a given stratigraphic unit was identified as not present (NP), the unit was assigned a top contact depth equal to the top of the underlying unit, resulting in a stratigraphic thickness of zero. Unit contacts that were labeled as "undetermined" or "not documented" were left blank. Note that if a stratigraphic unit was labeled as "not present" directly above a unit where the contact was undetermined, then its contact was also left blank. However, when the upper unit contact was undetermined (e.g., H1) but a lower unit contact (e.g., H2) possessed a known depth, then the upper unit was given the same contact depth as the next lower unit, to provide the greatest accuracy in unit thickness. Where all units were marked as undetermined, the unit was left blank. Also, at the time of this writing, Holocene deposits (including backfill and eolian sand) were not differentiated from each other and often were not assigned a specific depth to their top contact. Instead, the top contact for this unit was assumed to be the ground-surface elevation at a depth of zero feet.

The compiled stratigraphic contact data were organized into an electronic spreadsheet database (Appendix A). In keeping with the desire to provide the major (i.e., first-order) formation contacts as well as the second-order (e.g., member or facies association) architectural (mappable) stratigraphic units, columns for the formation level contacts were added to this spreadsheet. Where the uppermost subunit (e.g., member or facies association) of the formation had been identified, that depth value was used as the depth to the top of the formation. However, where the uppermost subunit was not determined either to be present or to be missing, then the depth to the top of the formation was left blank.

Where multiple depths were recorded for a given contact in a given borehole, a subjective evaluation was made to select the best-estimate contact depth. Best-estimate contact depths were identified for 452 different boreholes in and around the 200 West Area. These best-estimate picks were selected based on the professional judgment of Washington State licensed geologists. In many cases, the best estimate was taken as the most recently reported value. Other considerations included the extent of analysis and documentation provided by the source documents (see Table 5.2). For example, contacts from source documents that presented good detailed description of the borehole geology that was traceable back to the raw borehole data (e.g., Serne et al. 2004a, 2004b) and/or provided geologic interpretation in the context of surrounding boreholes through the use of cross sections, structure contour maps, isopach maps, and so on (e.g., Williams et al. 2002) were given a higher rank and priority over those that appeared to mostly summarize previous studies (e.g., Reidel and Chamness 2007). In a great number of cases, particularly in boreholes with older interpretations, the best-estimate pick developed for this report was based on a composite of the recorded contacts. ${ }^{(1)}$ These new best-estimate picks are identified in Appendix A with the source code of "Bjornstad08” and the date published as "This Report.” Other best-estimate contact records made specifically for this study were similarly identified with the name of the geologist making the picks and identified with the date published as "This Report." Note that best-estimate picks developed for this study were not ranked. The best-estimate depths were evaluated and revised based on integrated geologic interpretation of other nearby contacts in the context of geologic cross sections, structure contour maps, isopach maps, and solid model representations.

\footnotetext{
${ }^{1}$ B. N. Bjornstad, personal communication, Excel files sent to G. V. Last via email dated January 16, 2008.
} 


\subsection{Evaluation and Verification of Best-Estimate Contacts to Raw Borehole Data}

An evaluation of the best-estimate contact picks was conducted by graphically comparing the stratigraphic contact picks to summary logplots of the raw and standardized borehole data (where available). Figure 5.3 illustrates the location of the 198 boreholes in and adjacent to the 200 West Area, for which logplots are available. Of these 198 boreholes, 115 also had best-estimate contact data available. A graphical comparison of the best-estimate contacts to the raw, standardized borehole data summarized in the logplots was conducted using Adobe Illustrator. ${ }^{1}$ This allowed the imported logplot files to be directly overlain with stratigraphic contact lines based on the best-estimate contact depths found in the stratigraphic contacts database (as it was in the file titled Contact Depths_2008-06-25.xls, tab 200 W Contact Depths NRV dated June 25, 2008). The depths of the contact lines were then compared to the logplots to evaluate their validity and adjusted where necessary. Of the 115 wells evaluated, 26 (23\%) had contact picks that lined up exactly with lithologic units shown on the logplots, 61 (52\%) had contacts within $2 \mathrm{ft}$ of agreement, 19 (17\%) had contacts within $5 \mathrm{ft}$ of agreement, and $9(7 \%)$ had areas of undetermined lithologic contacts. Note that the evaluation categorized above represents the worst case for a particular borehole, as some boreholes had contacts ranging from perfect agreement to within $5 \mathrm{ft}$ of agreement.

\subsection{Ground-Surface Elevation Data}

Appendix B presents the best-estimate ground-surface elevations, in meters, based on data available through the HWIS when available. The best-estimate ground surface elevations (presumably at the time of drilling, and presumably relative to NAVD88 [North American Vertical Datum of 1988]) used in this report were calculated using the following set of logic rules:

1. If the HWIS contained a ground surface elevation value in meters with a survey point described as "brass survey marker," "ground surface," or "ground surface (assumed)," that value was used as the ground surface elevation (in meters).

2. If the HWIS did not contain vertical survey value as described above but did contain a "DISC_Z" value, that value was used as a proxy for the ground-surface elevation. Note that, when compared, those values identified as the elevation of the brass survey marker and the DISC_Z values were identical when rounded to the nearest $0.01 \mathrm{~m}$.

3. If neither 1 nor 2 above was applicable, then the ground-surface elevation was calculated from the HWIS vertical survey value described as having been surveyed from the top of one of the casings or the top of the pump plate using the HWIS stickup value (converted from feet to meters using a conversion factor of $0.3048 \mathrm{~m} / \mathrm{ft}$ [Thompson and Taylor 2008]; $3.28084 \mathrm{ft} / \mathrm{m}$ ). If multiple stickup values were found, then the stickup value associated with the earliest documented inspection date was used as most representative to yield the ground-surface elevation at the time of drilling.

4. If a stickup value was not available from the HWIS, then a default stickup value of $0.914 \mathrm{~m}$ (3 ft) was used to calculate the ground-surface elevation.

\footnotetext{
${ }^{1}$ Adobe ${ }^{\circledR}$ and Illustrator ${ }^{\circledR}$ are registered trademarks of Adobe Systems Incorporated, San Jose, California.
} 


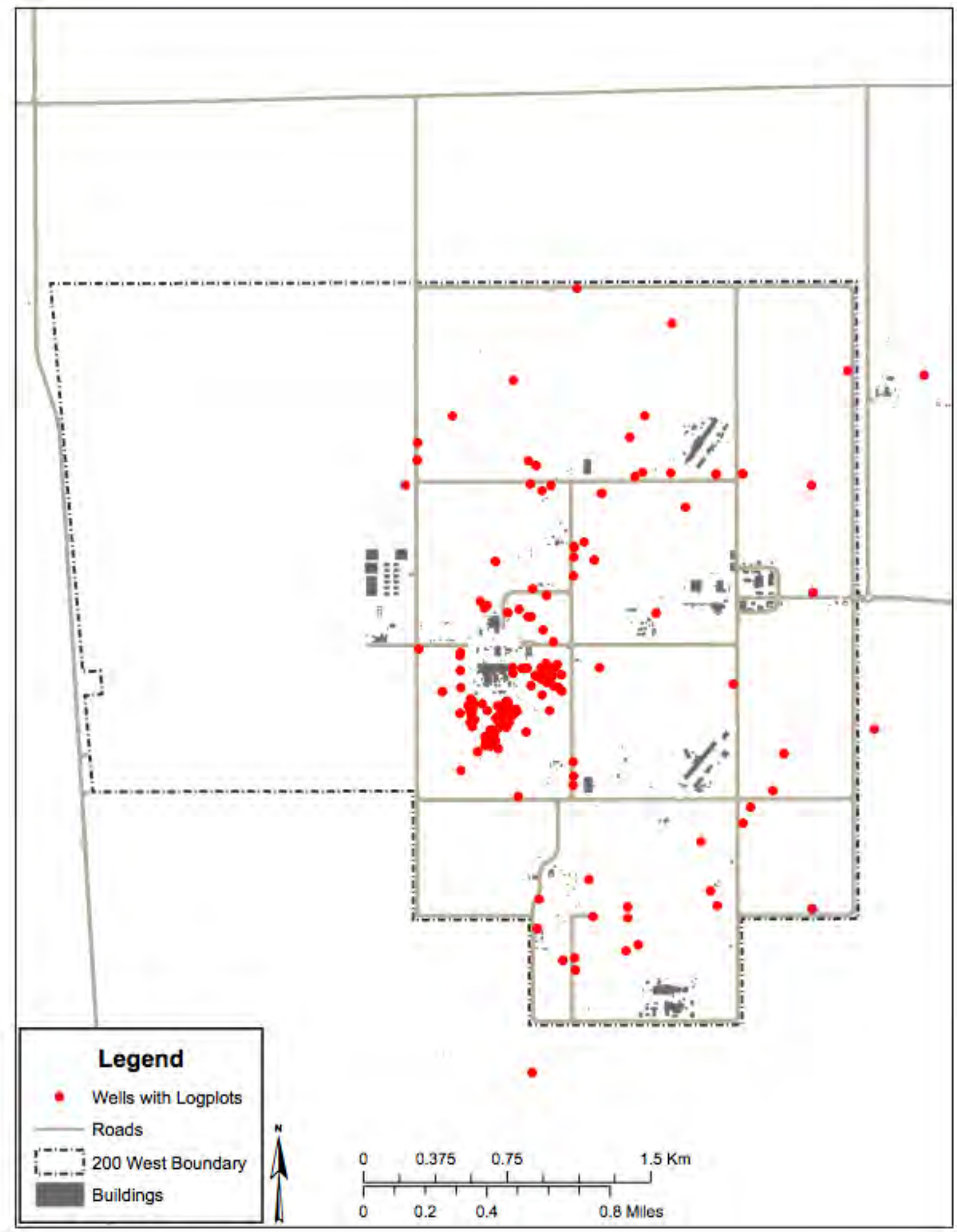

Figure 5.3. Location of Boreholes in and Adjacent to the 200 West Area, for Which Logplots Are Available 
5. If there was no vertical survey value for the top of casing, then the ground-surface elevation was left blank and flagged for future estimation using professional judgment, or it was estimated based on the ground-surface elevations for nearby wells and/or the surrounding topography. In some cases, elevation data were found in borehole completion reports or other reference sources.

6. Where the ground-surface elevation is known to have been altered after the borehole was drilled (e.g., soil cover added at BC cribs), and/or the estimated ground-surface elevation based on the HWIS data is suspected to not be representative of the time of drilling, then historical ground-surface elevation data from old Hanford Site wells documents (e.g., McGhan 1989) were used to estimate the ground surface at the time of drilling.

The HWIS vertical survey data are reported in meters using the NAVD88. However, stickup values and other older elevation values (e.g., Hanford Wells [McGhan 1989]) often are in feet using the NGVD29. Thus, these values first were converted to meters using the NAVD88 prior to calculating the best-estimate ground-surface elevation at the time of drilling. Current and historical stickup values also are documented in feet, so these also were converted to meters for subsequent calculations.

\subsection{Contact Elevations}

Contact elevations (in meters) were calculated by subtracting the best-estimate stratigraphic contact depths (converted to meters using a conversion factor of $0.3048 \mathrm{~m} / \mathrm{ft}$ ) from the best-estimate groundsurface elevation in meters (see Section 6). These results were then used to develop a solid earth representation of the hydrogeology beneath the 200 West Area. 


\subsection{Stratigraphic Model of the Central Plateau}

A large-scale stratigraphic model of the Central Plateau (focusing on the 200 West Area) was developed to capture existing published interpretations on the major heterogeneities within the subsurface framework distinguished by unconformity-bound stratigraphic sequences (e.g., formations).

Intermediate-scale stratigraphic units representing second-order heterogeneities defined by depositional sedimentary sequences or packages (e.g., members or facies associations) also were included. This inclusion was accomplished by assembling the stratigraphic contacts information described in Section 5 into a three-dimensional geologic model and then verifying and refining the geologic model through evaluation of anomalies and independent cross section analyses.

\subsection{Three-Dimensional Model}

The best-estimate stratigraphic contact data and best-estimate ground-surface elevation data (Section 5) were manipulated to create an input file of best-estimate contact elevations in meters for use in EarthVision software to create a 3D model of the major stratigraphic units beneath the 200 West Area. Minimum tension gridding was used to fit the unit surfaces to the data points. Minimum tension gridding produces an initial estimate for each grid node based on the distance weighting of the nearest data points, and then an iterative biharmonic spline function is used to minimize curvature in the estimated surface topography while maintaining an accurate fit to the data points.

The resulting EarthVision model consists of a "facies" file that represents each unit as a zone within a solid 3D block. The surface of each unit is defined by an XYZ grid with XY spacing of $10 \mathrm{~m}$. The model domain is 9,100 m wide and 6,100 m long. The vertical extent of the model is from $-20 \mathrm{~m}$ to $250 \mathrm{~m}$ in elevation (NAVD88). Figure 6.1 shows the model domain and also shows the location of key facilities. The facies file or XYZ grids can be sampled using utilities provided in the EarthVision software to create input files for numerical flow models. Three-dimensional property distributions can also be applied within one or more geologic units of the model.

The following procedure was used to build and revise the geologic model:

1. Grids representing the tops of extensive stratigraphic units (present over most of the model domain) were created based on the elevation contact picks for 446 boreholes and wells. Information from boreholes where particular units were interpreted as missing was used to constrain unit extents. Control points (pseudo data) were added in areas where borehole data were sparse, particularly on the edges of the model domain, to control model extrapolation. Other control points were sometimes used to control the configuration of a unit surface using professional judgment based on knowledge of the depositional and erosional environment.

2. Thickness (isopach) grids were calculated for less extensive geologic units based on the thickness measured at wells and zero thickness for the not present (NP) flags in the well data. For these less extensive units, it was generally assumed that the unit was not present in areas where there were no data for the unit.

3. Starting from the base of the model, grids for the top elevation of each less extensive geologic unit were calculated by adding the thickness grid to the elevation grid for whichever unit exists below it. 


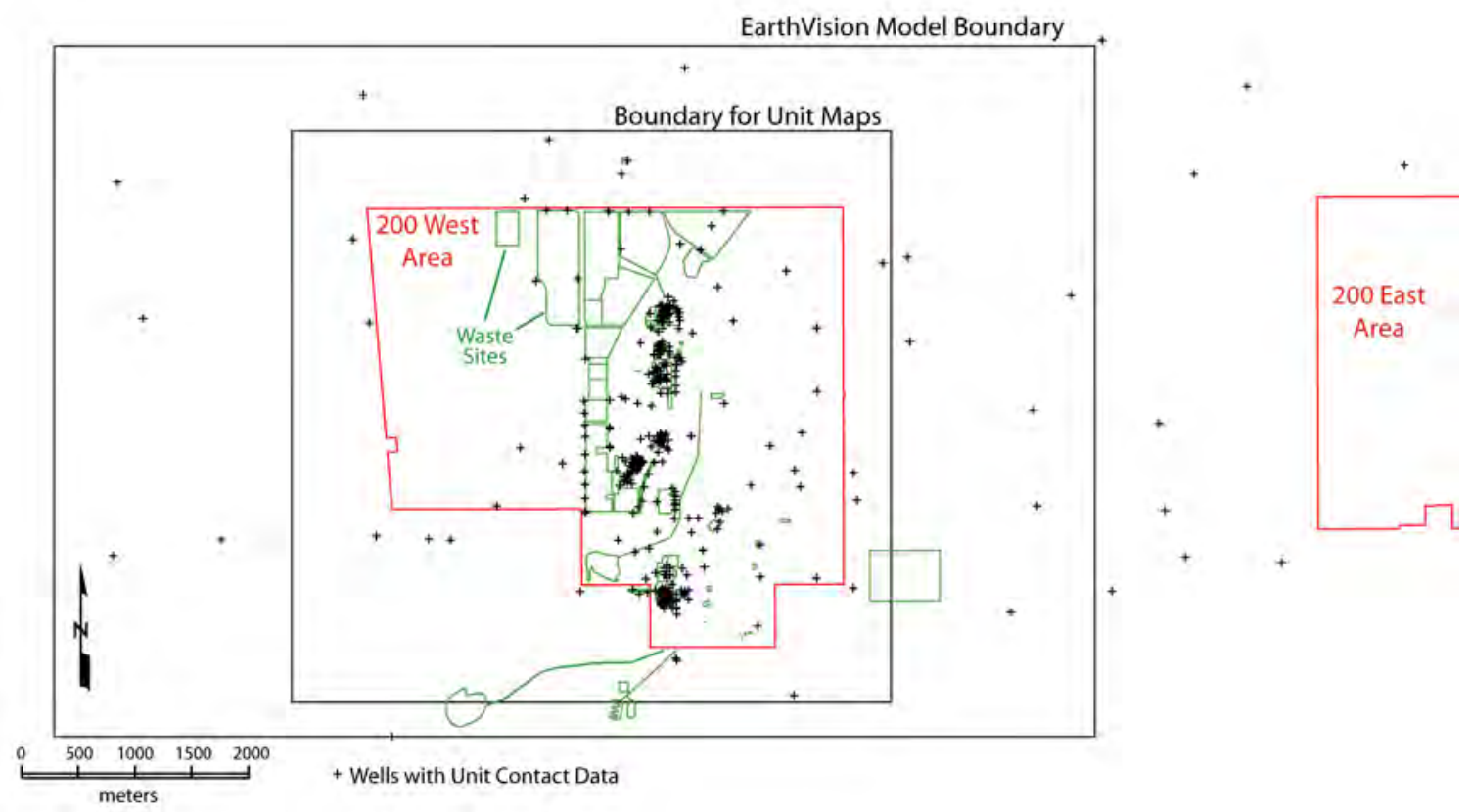

Figure 6.1. EarthVision Model Domain for the 200 West Area Geologic Model. Note that the model boundary extends beyond the study area boundary used in subsequent figures, to reduce edge effects.

4. The model was examined to determine if any units had incorrectly "pinched-out" because the top of a deeper unit was being extrapolated above the elevation of the well pick. If this occurred, control points were added to control the top surface of the deeper unit.

Development of the solid geologic model in EarthVision was an iterative process because examination of the model identified a few wells (estimated at less than $5 \%$ of the wells) where elevation picks were inconsistent. The geologic data were then reevaluated by reviewing/evaluating the raw borehole data to determine whether the picks were valid. The EarthVision model is displayed as a block diagram (Figure 6.2) and as a series of structure contour maps (Figures 6.3-6.12). Appendix C provides additional visual representations of the model (including additional block diagrams, isopach maps, and cross sections), as well as the input file for the model. Measurements used in these figures are in metric units. 


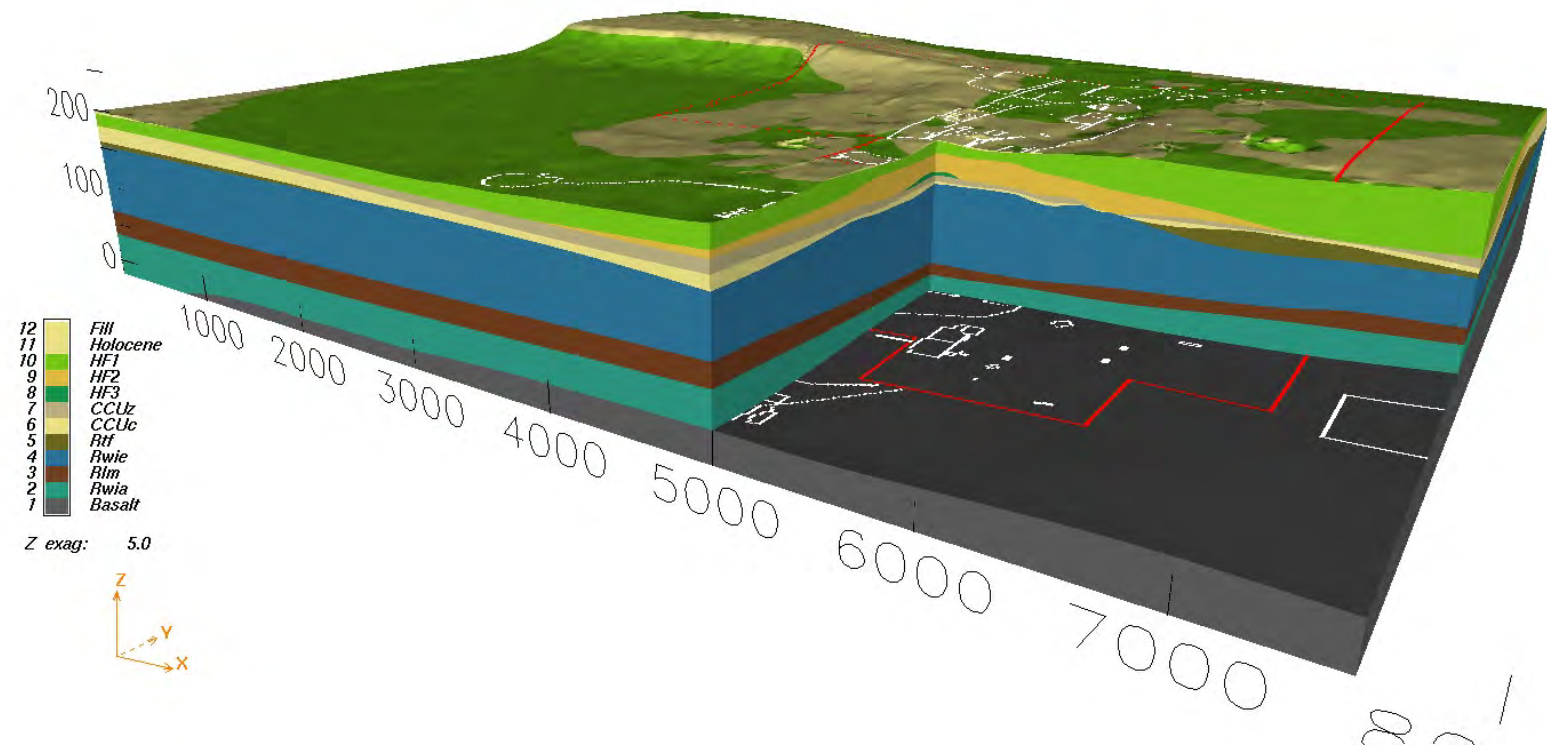

Figure 6.2. Three-Dimensional Geologic Model with Cutout Through the Central and Northern 200 West Area, Approximating Cross Sections B-B' and F-F'. View is to the northnorthwest, with the $y$-axis pointing north and the $x$-axis pointing east; scales are in meters. Vertical exaggeration is 5 times the horizontal. 


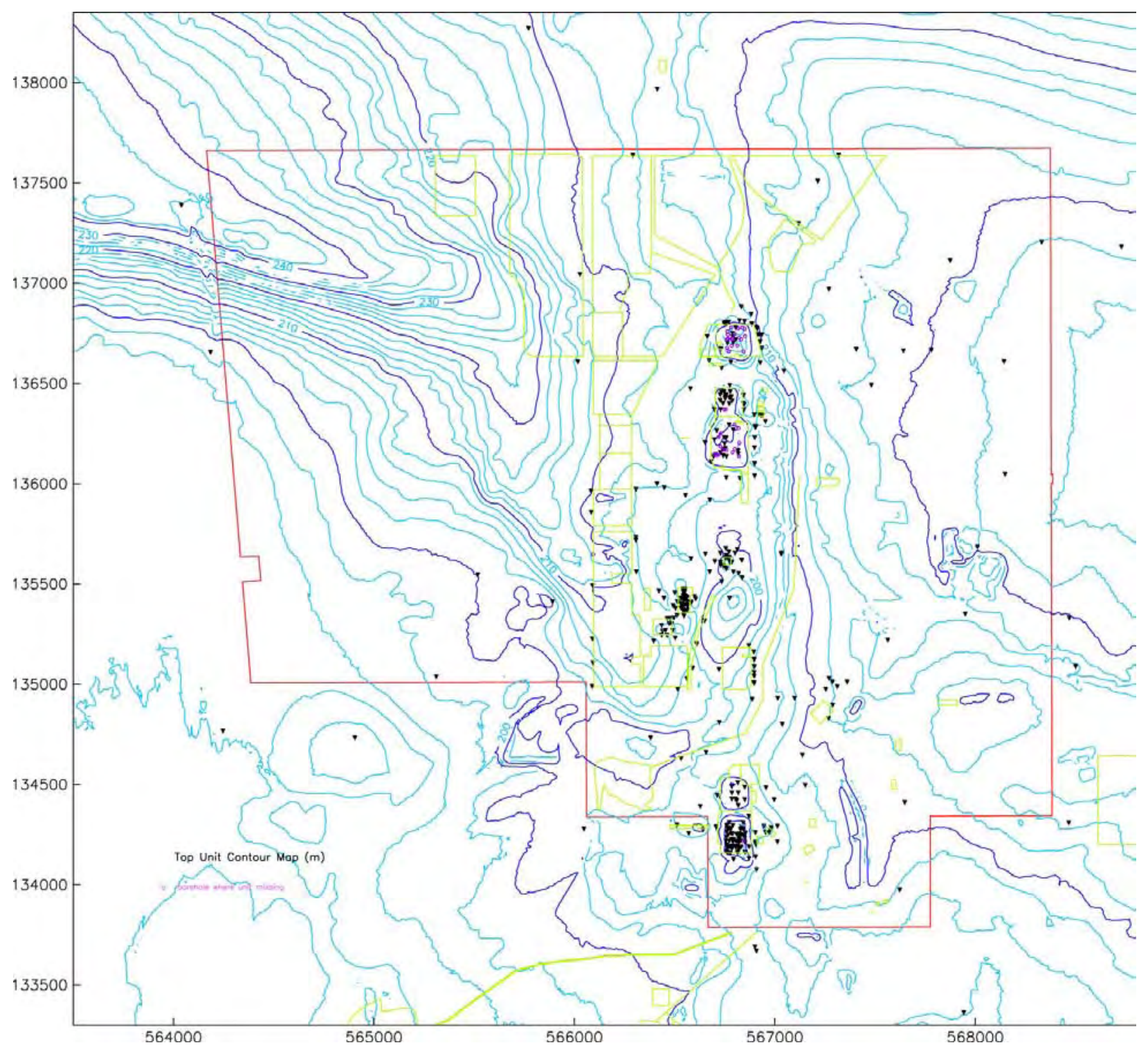

Figure 6.3. Structure Contour Map for the Top of the Hanford H1 Unit in and Around the 200 West Area. The irregular surface in the central and southern 200 West Area is due to man-made excavations associated with subsurface facilities (e.g., tank farms). Contours are in meters above mean sea level (MSL). 


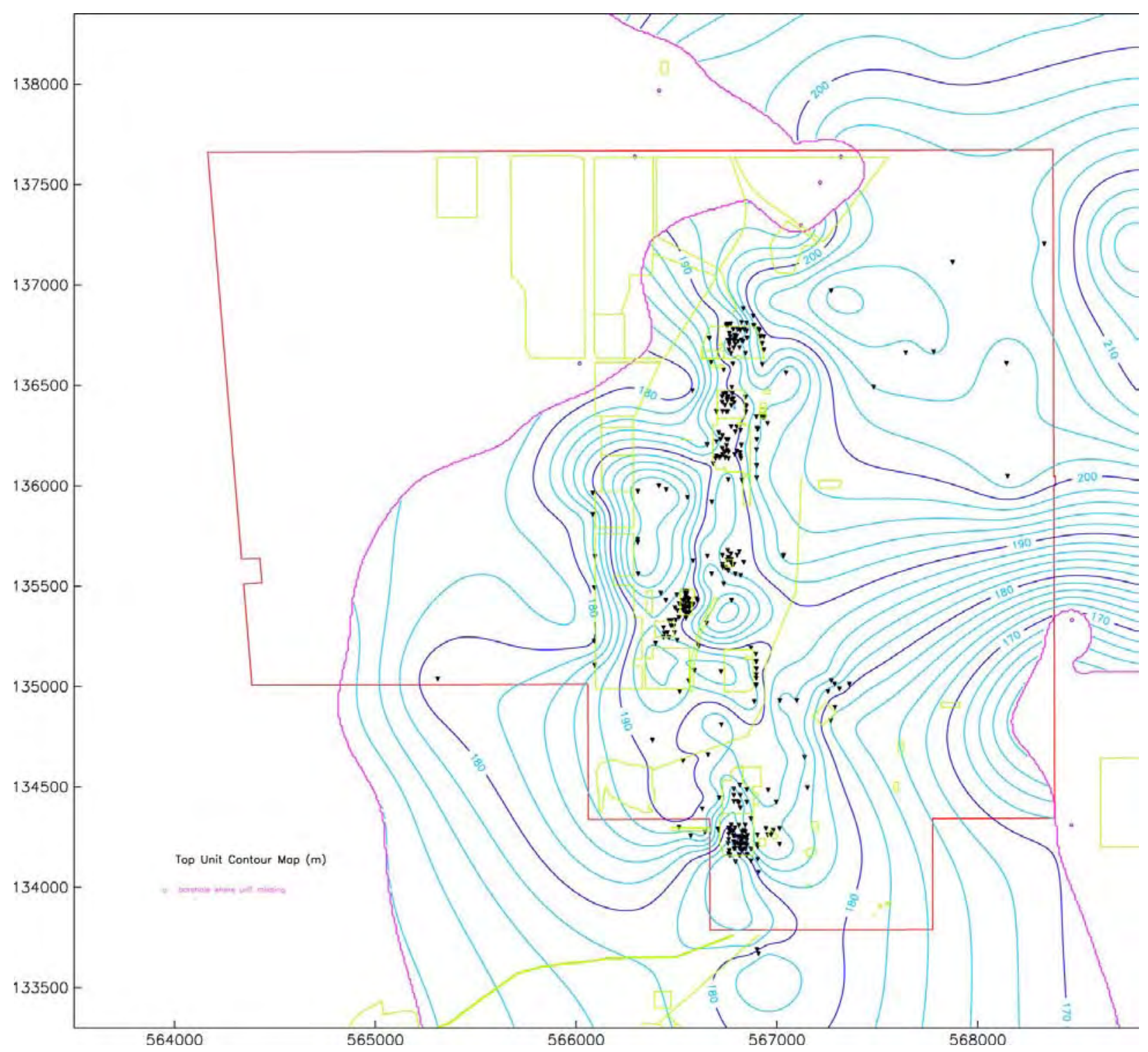

Figure 6.4. Structure Contour Map for the Top of the Hanford H2 Unit in and Around the 200 West Area. Contours are in meters above mean sea level (MSL). 


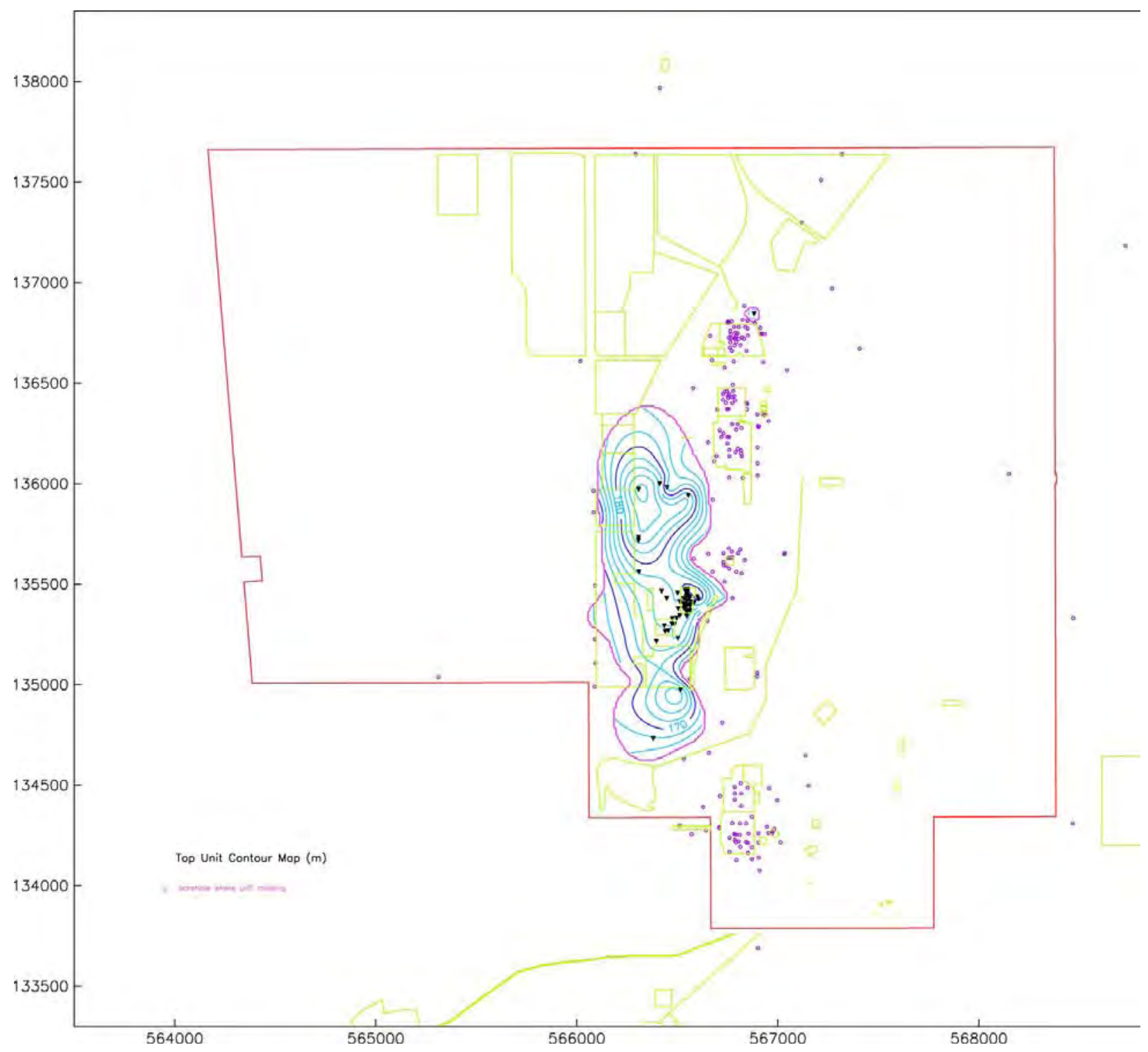

Figure 6.5. Structure Contour Map for the Top of the Hanford H3 Unit in and Around the 200 West Area. Contours are in meters above mean sea level (MSL). 


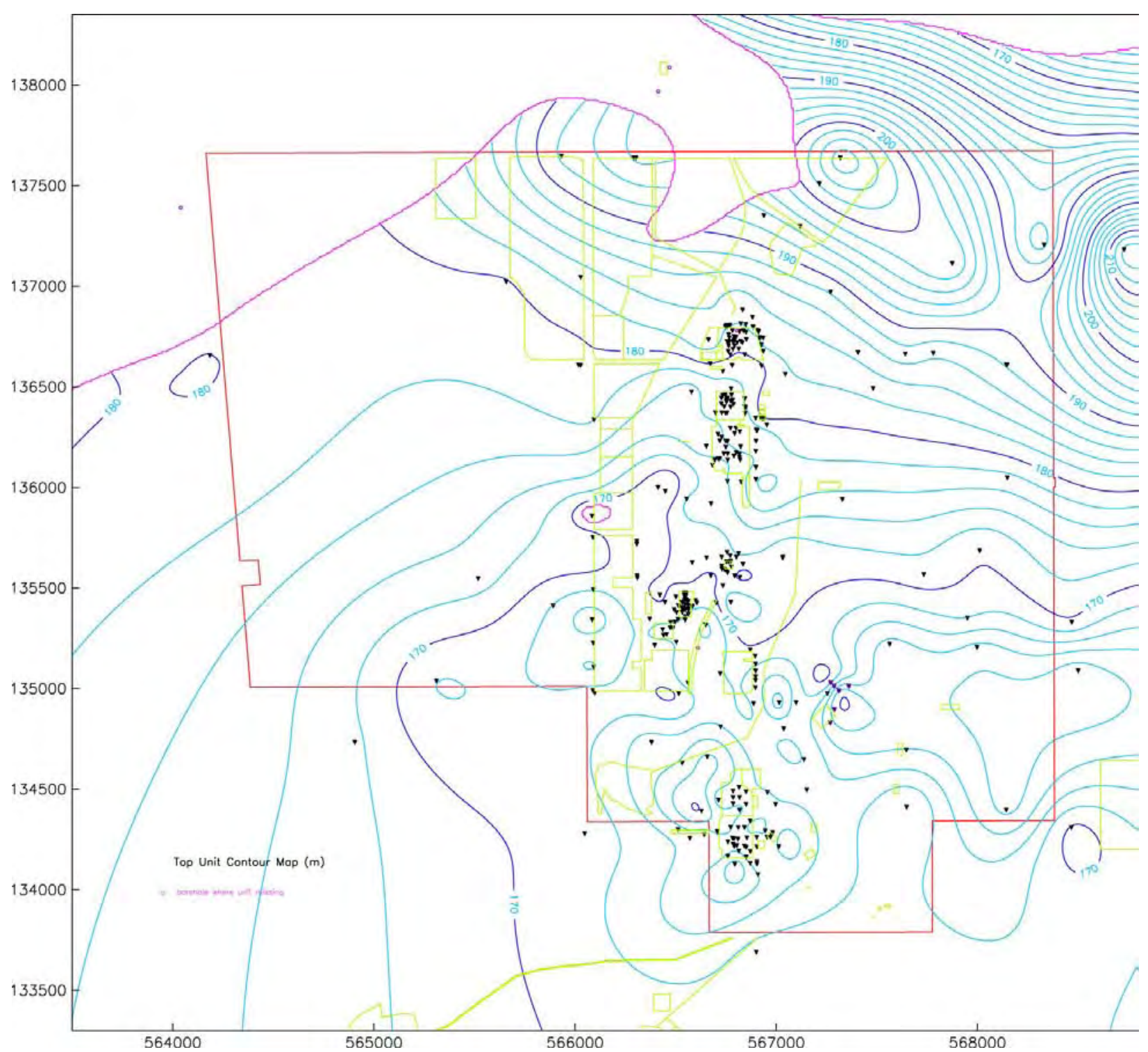

Figure 6.6. Structure Contour Map for the Top of the Cold Creek Unit Silt in and Around the 200 West Area. Contours are in meters above mean sea level (MSL). Note that this unit is missing along the northern portion of the study area. 


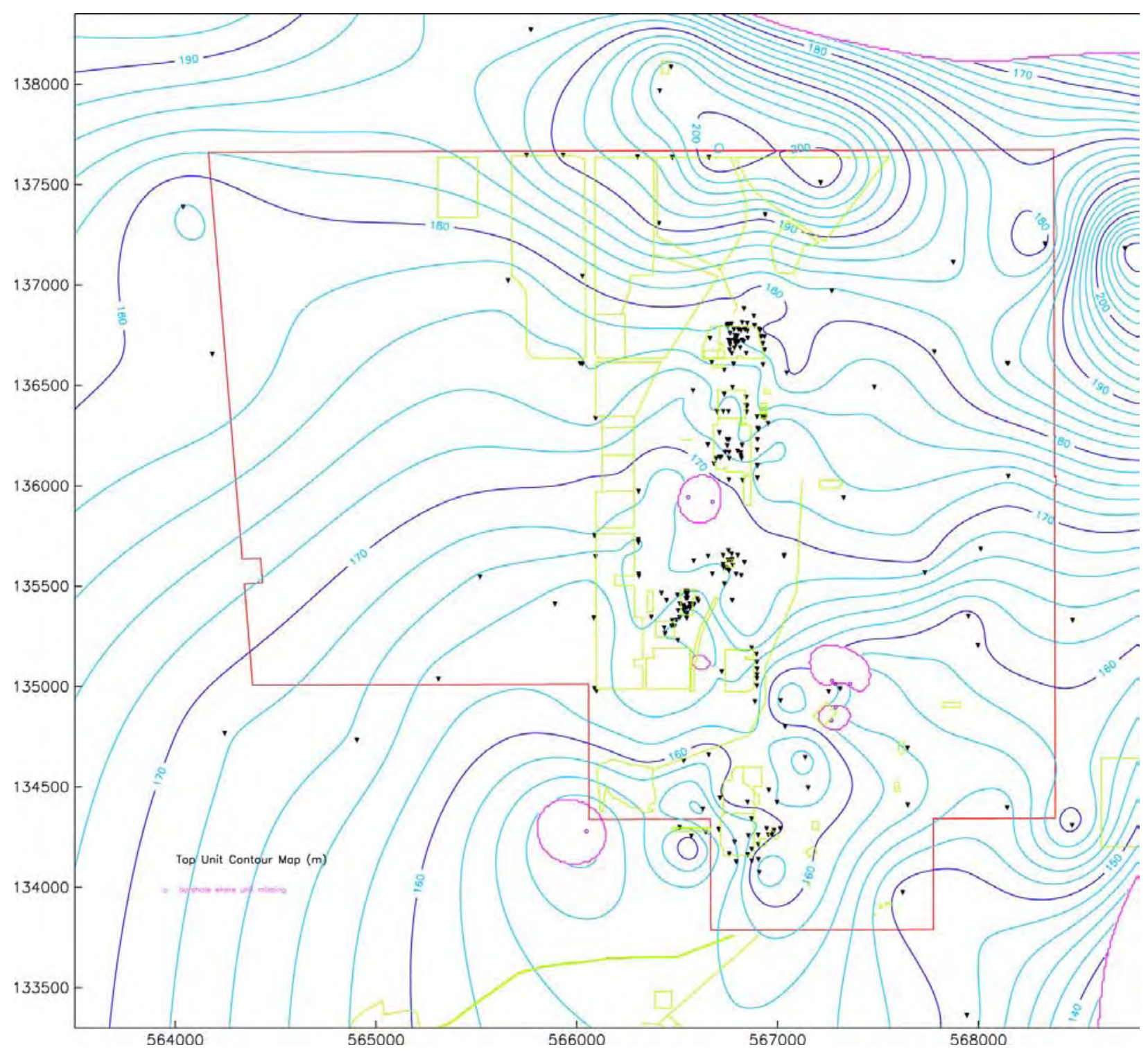

Figure 6.7. Structure Contour Map for the Top of the Cold Creek Unit Carbonate Unit in and Around the 200 West Area. Contours are in meters above mean sea level (MSL). 


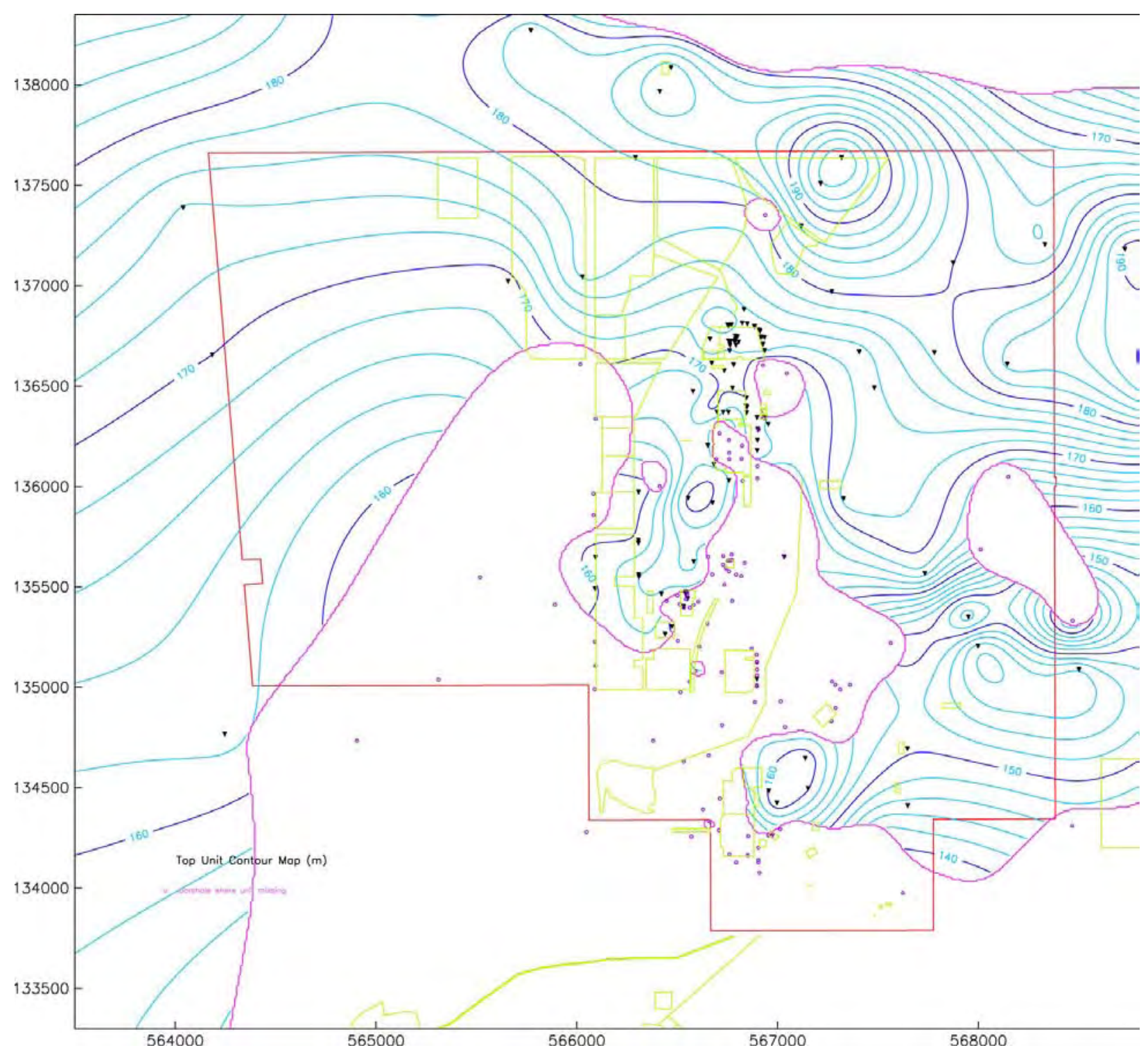

Figure 6.8. Structure Contour Map for the Top of the Ringold Formation, Member of Taylor Flat, in and Around the 200 West Area. Contours are in meters above mean sea level (MSL). 


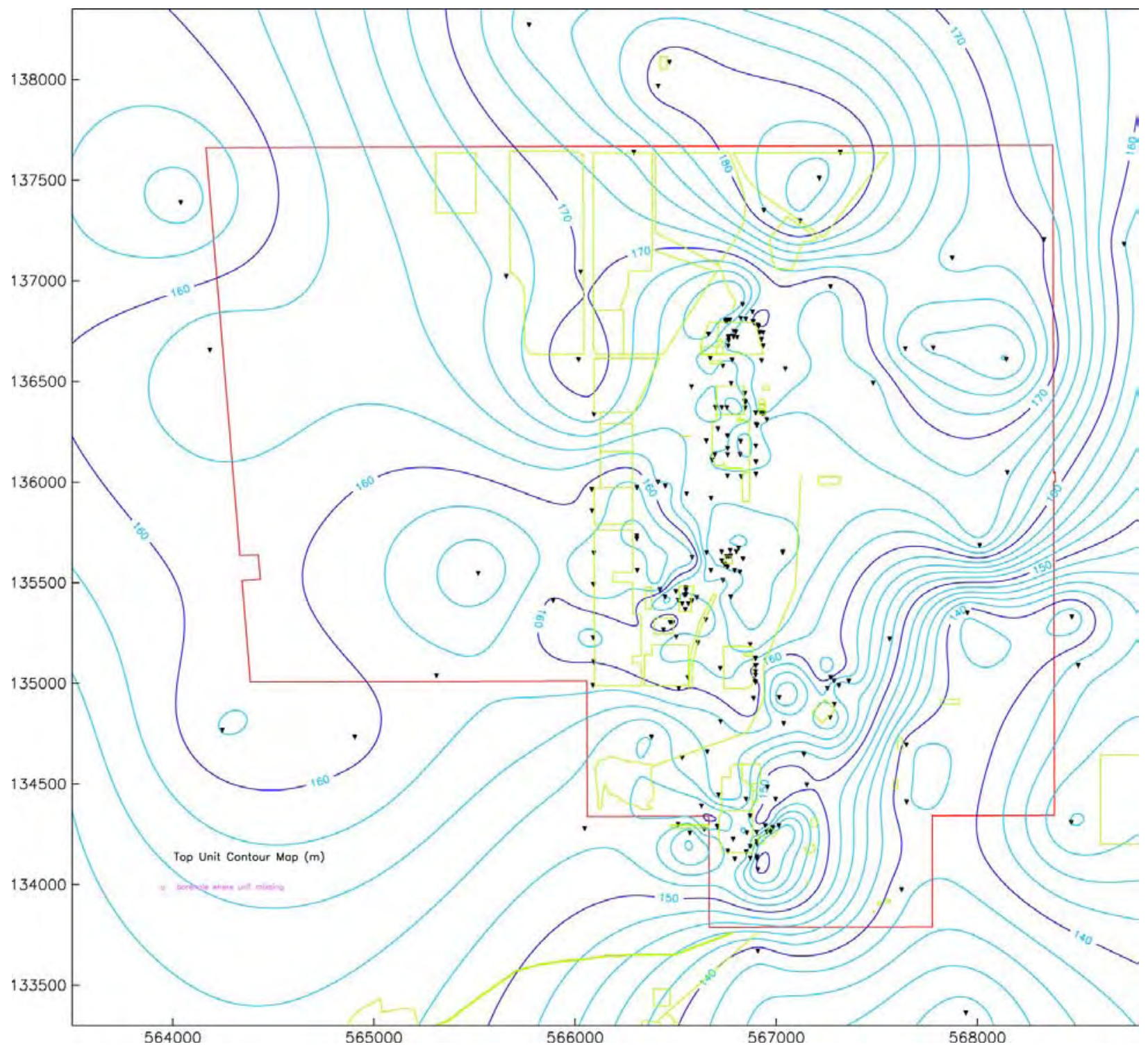

Figure 6.9. Structure Contour Map of the Top of the Ringold Formation, Member of Wooded Island, Unit E, in and Around the 200 West Area. Contours are in meters above mean sea level (MSL). 


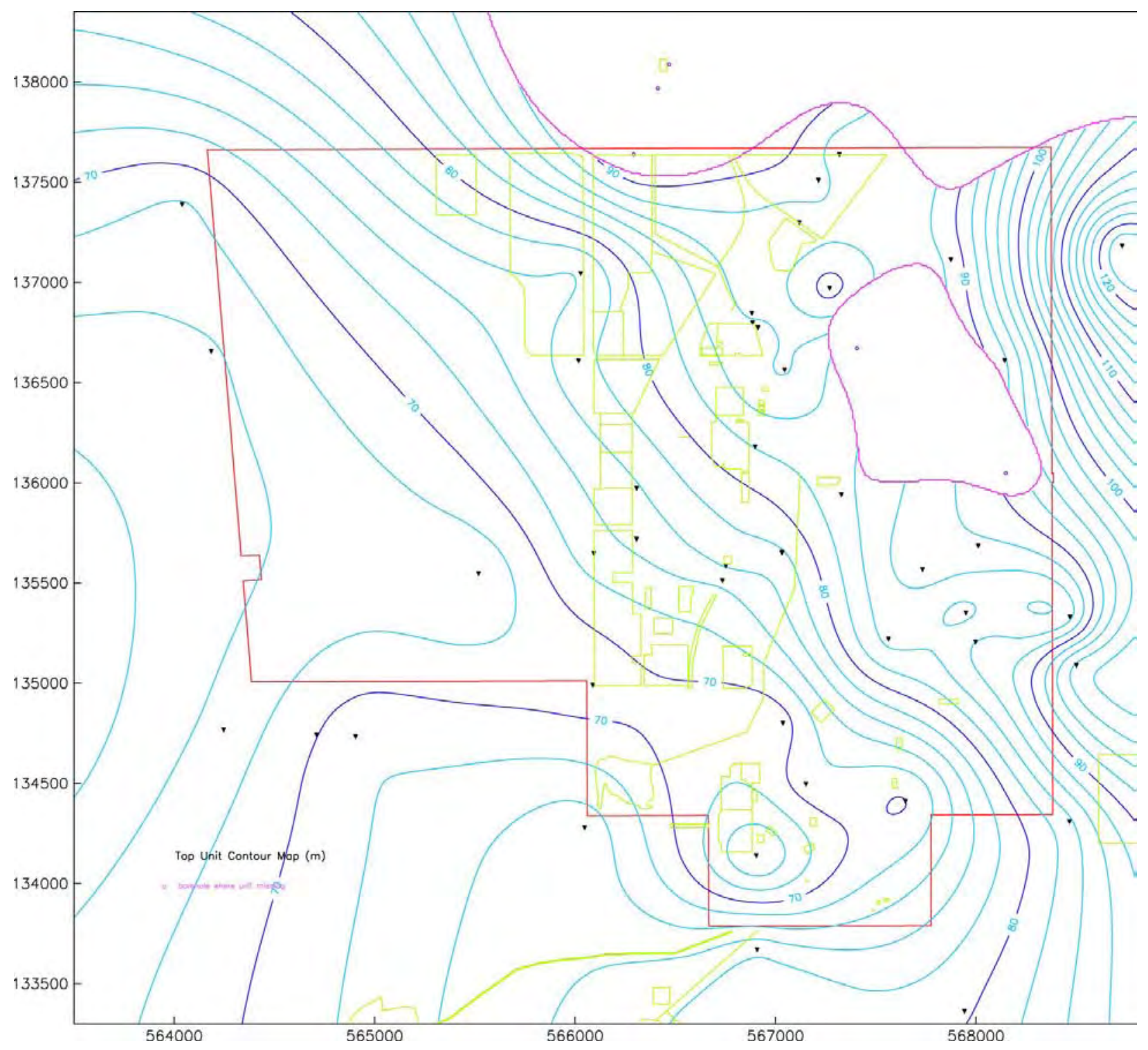

Figure 6.10. Structure Contour Map of the Top of the Ringold Formation, Lower Mud Unit, in and Around the 200 West Area. Contours are in meters above mean sea level (MSL). 


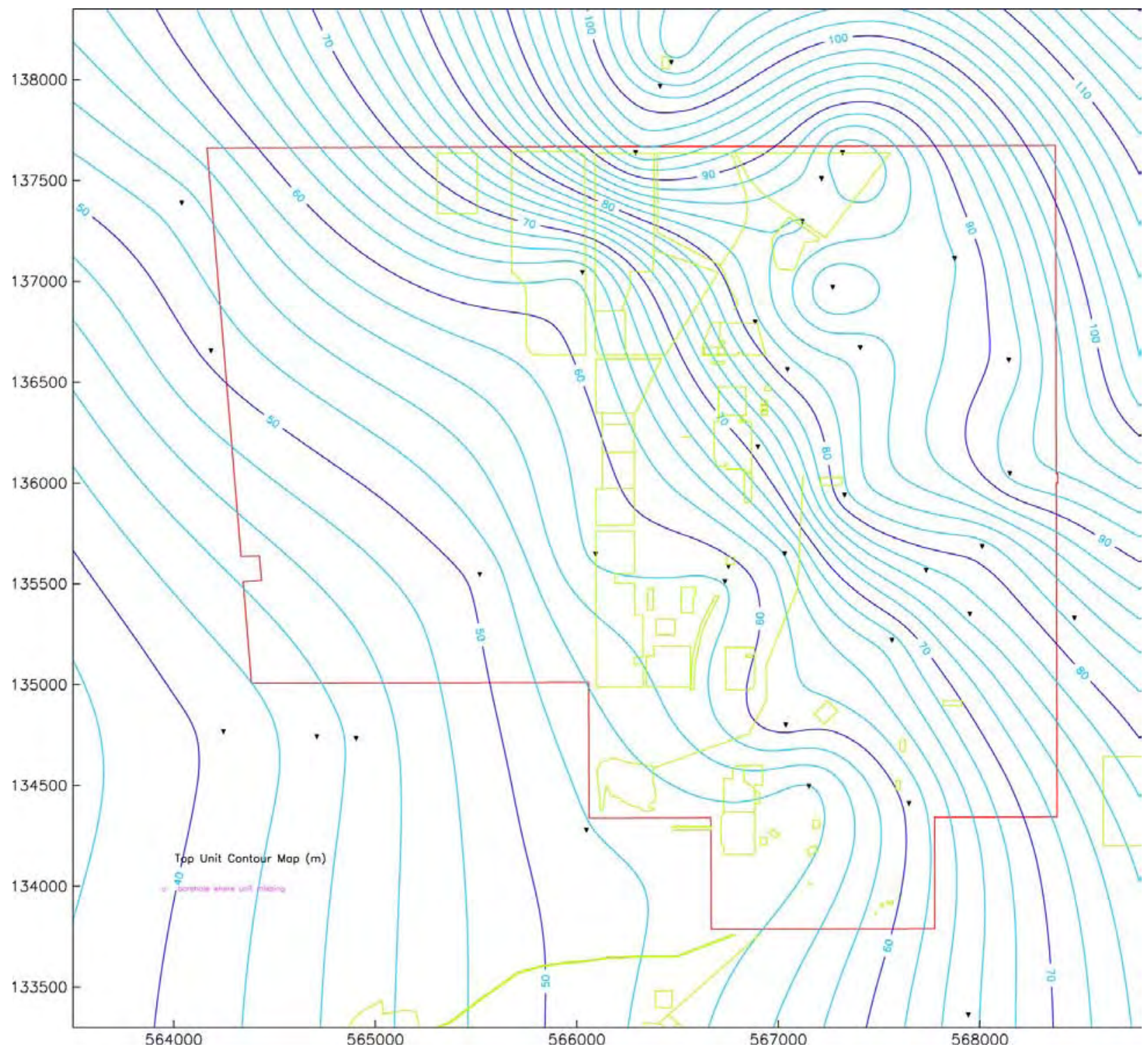

Figure 6.11. Structure Contour Map of the Top of the Ringold Formation, Member of Wooded Island, Unit A, in and Around the 200 West Area. Contours are in meters above mean sea level (MSL). 


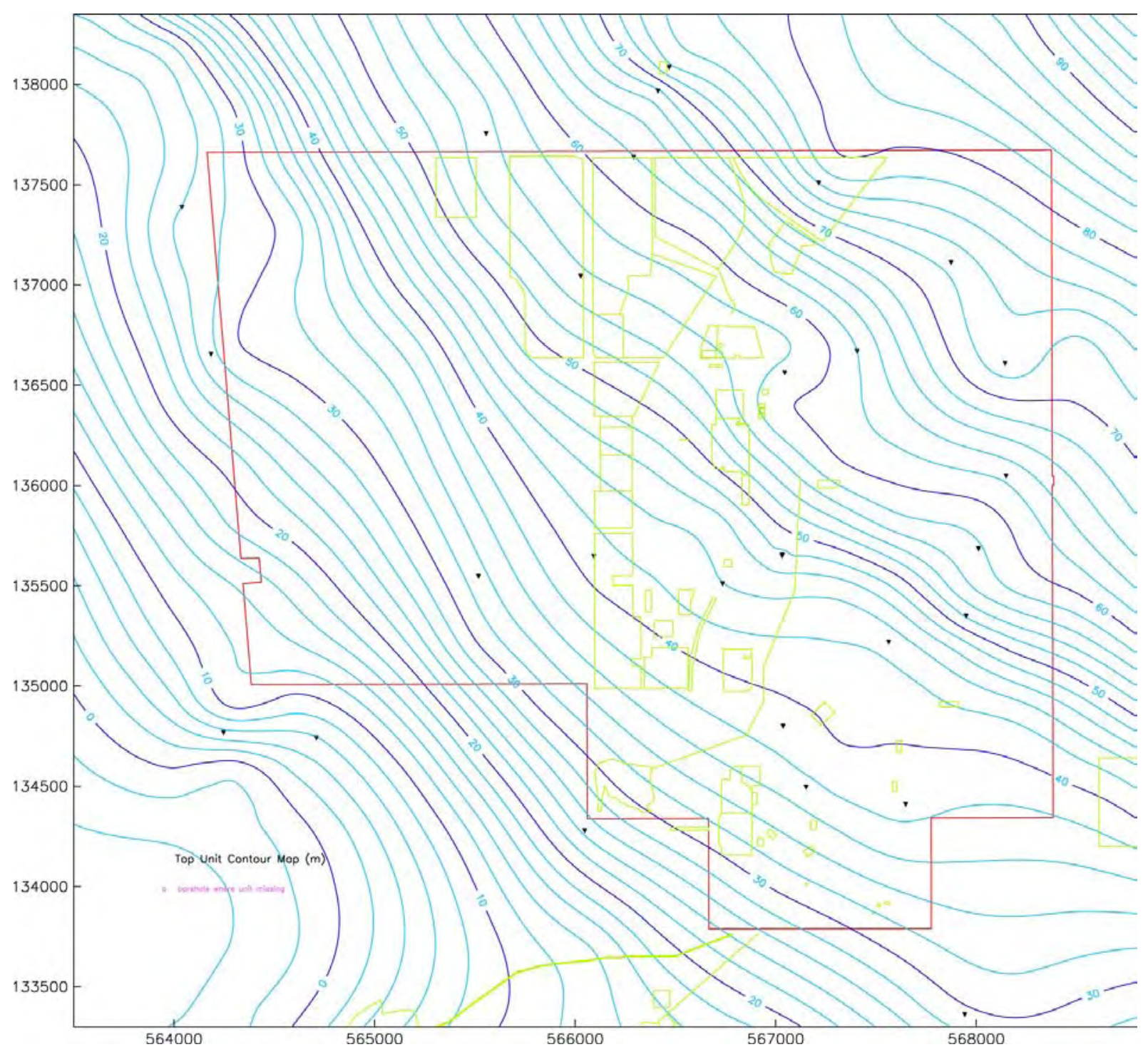

Figure 6.12. Structure Contour Map of the Top of Basalt (undifferentiated) in and Around the 200 West Area. Contours are in meters above mean sea level (MSL).

\subsection{Detailed Geologic Cross Sections}

Two geologic cross sections were constructed independently from the 3D model to help verify and refine the stratigraphic contacts data and 3D model and to provide additional details on finer-scale (thirdorder) heterogeneities found within some of the stratigraphic packages (Figure 6.13). A north-southoriented geologic cross section (Figure 6.14 and Appendix D; B-B') was selected to capture an abundance of borehole data through the center of the 200 West Area and roughly follows previously published geologic cross sections (Tallman et al. 1979; Lindsey 1991; Williams et al. 2002), allowing nearly direct comparison. This north-south cross section runs through the single-shell tank waste management areas, S, SX, T, TX, TY, and U. A second cross section was oriented east-west (Figure 6.15 and Appendix D; F-F') to provide additional detail across the northern portion of the 200 West Area and also roughly follows previously published geologic cross sections (Tallman et al. 1979; Lindsey 1991; Williams et al. 2002). 


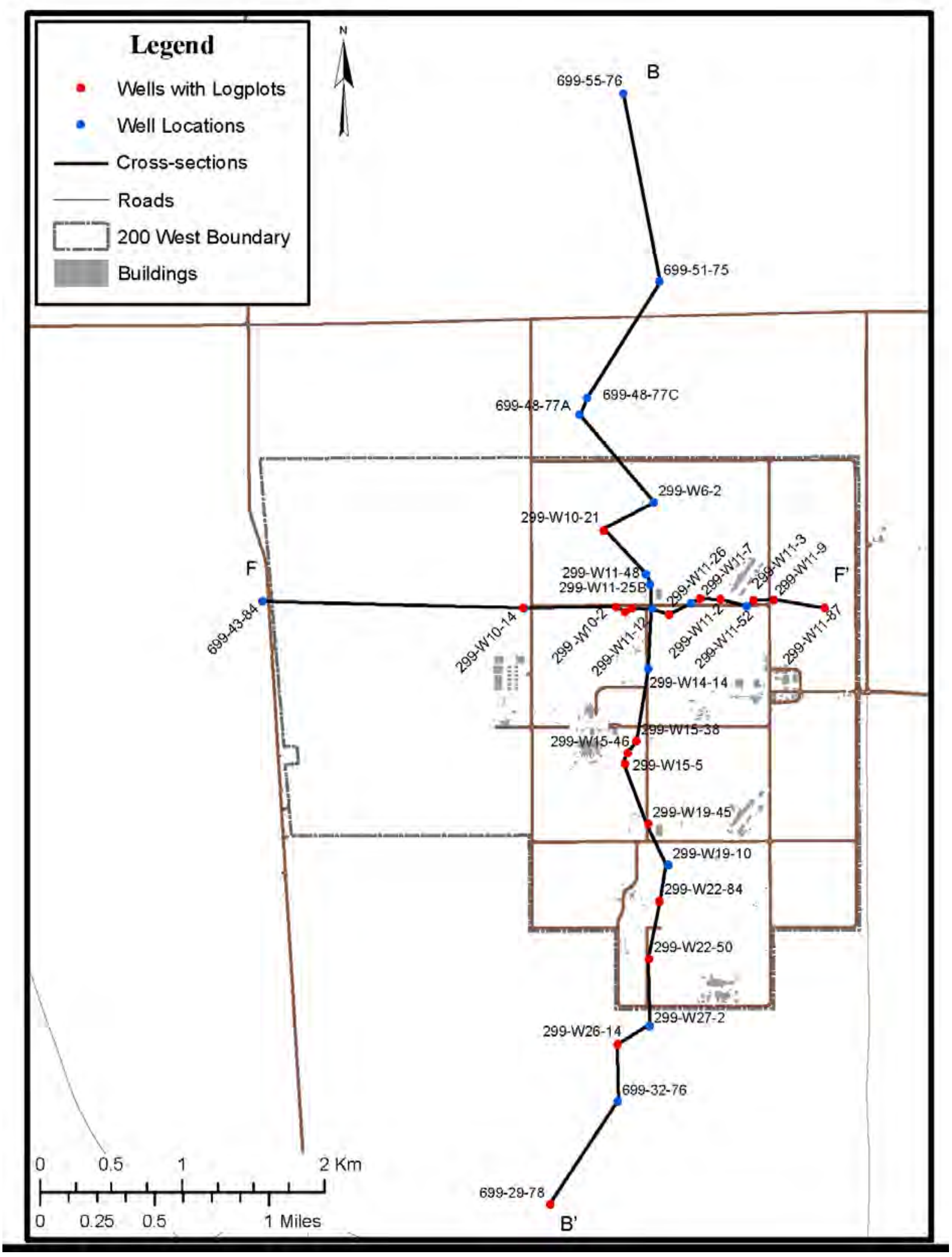

Figure 6.13. Location of Potential and Completed Cross Sections 


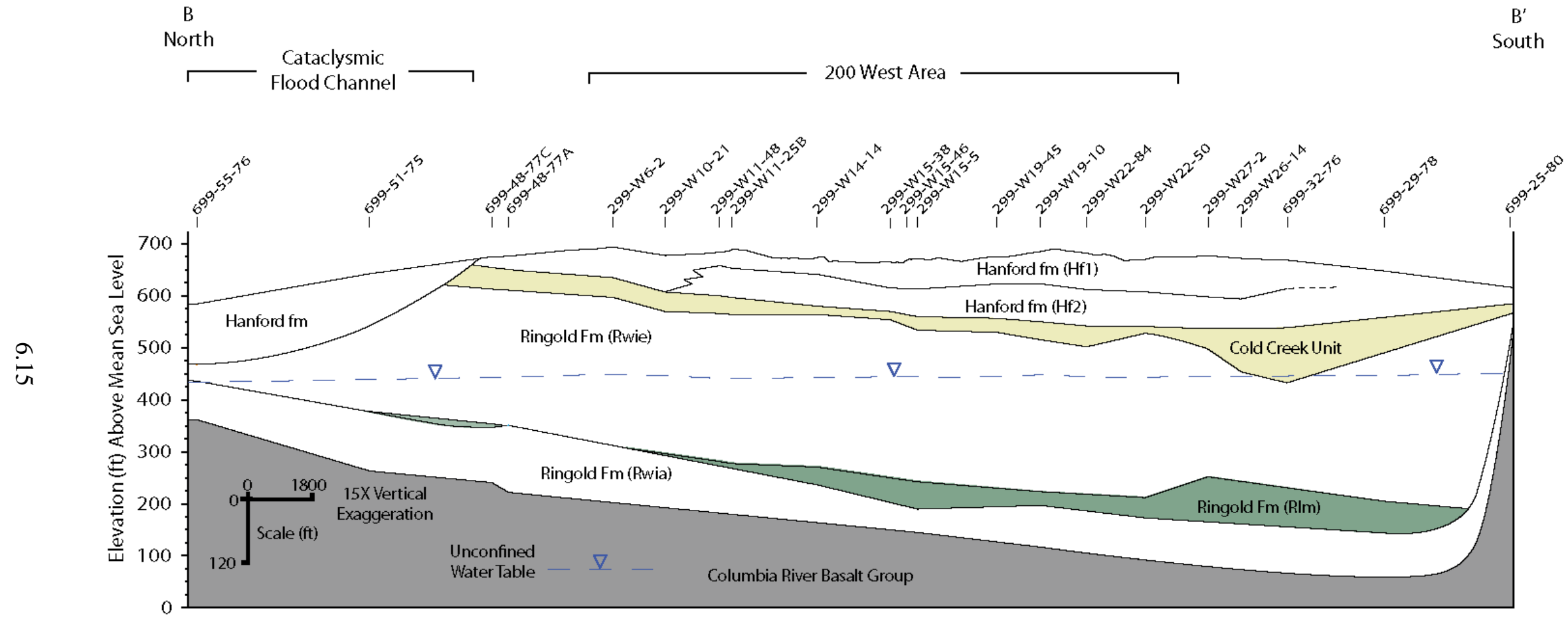

Figure 6.14. North-South Cross Section B-B' 


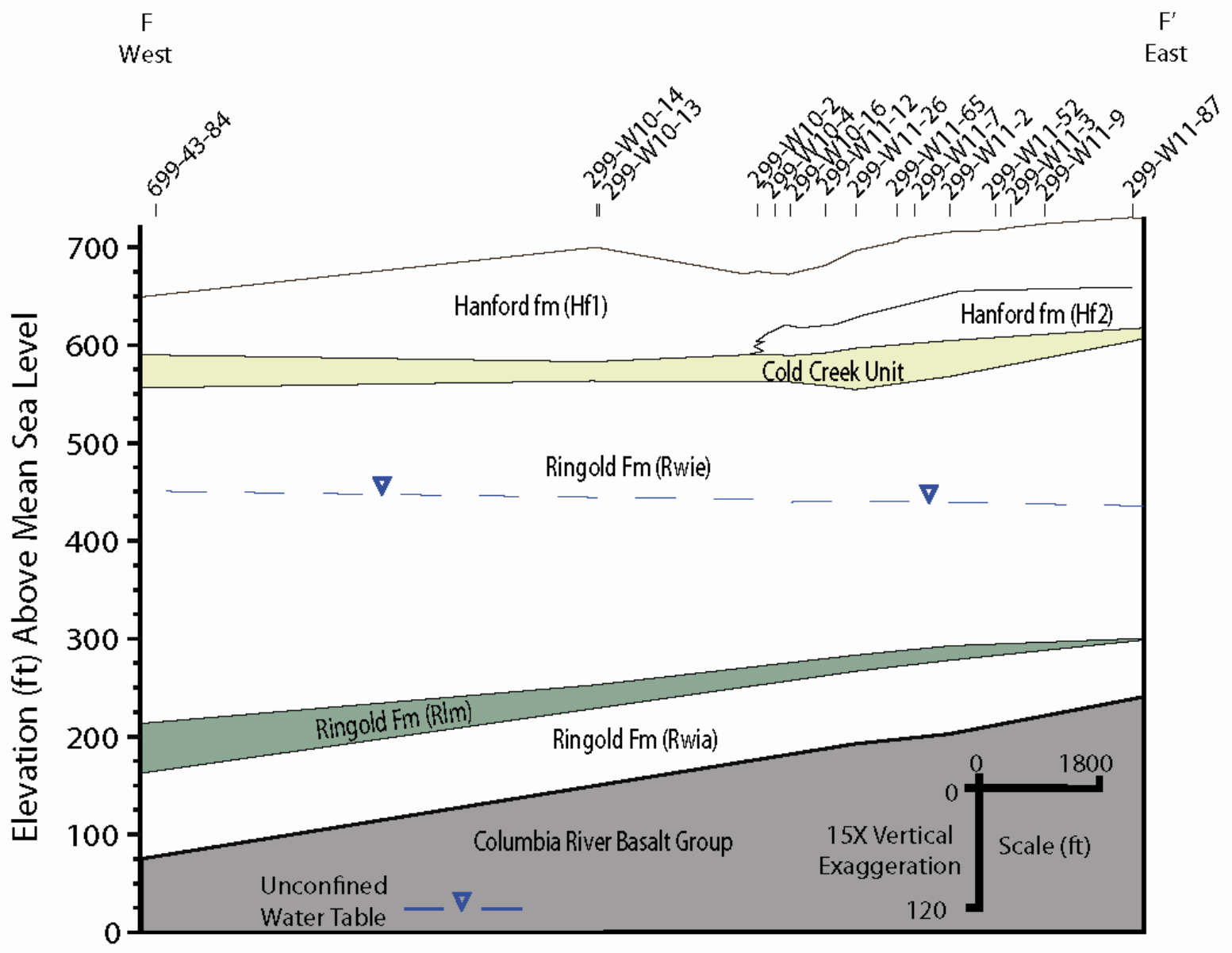

Figure 6.15. East-West Cross Section F-F'

The following procedure was used to build and revise the geologic cross sections:

1. Several potential cross sections were identified based on visual observation of borehole arrangement in relation to key areas of interest, such as waste sites, geologic structures, and stratigraphy (Figure 6.13). A list of selected boreholes for each transect was identified based on relative location to cross section lines of interest. Two cross sections (B-B' and F-F') were selected for completion during this phase of the study, based on abundance of boreholes with available logplots and/or published stratigraphic contacts.

2. An Excel ${ }^{1}$ file was produced from the list of selected boreholes, and multiple data fields (i.e., northing and easting coordinates, elevation, and borehole depth) were populated with data queried from the HWIS.

3. The Excel file was used to sort boreholes in order of arrangement along the selected cross section lines, and relative borehole distances were calculated using northing and easting coordinates published in the HWIS.

\footnotetext{
${ }^{1}$ Excel $^{\circledR}$ is a registered trademark of the Microsoft Corporation, Redmond, Washington.
} 
4. An Adobe Illustrator file was created with multiple layers using a cross-section scale of 10:1 vertical exaggeration. Graphic borehole logs created in LogPlot $2003^{1}$ were exported as .jpg files and placed into the Adobe Illustrator file. Best-estimate geologic contacts for each well (if available) were taken from the 200 W Contact Depths Database (dated September 11, 2008) and plotted on each borehole, and correlation lines drawn between boreholes for each formation and subformation contact.

Measurements on the cross sections were reported in English units (feet) because most well logs and drillers' records are recorded using the English units as the standard unit of measurement, thereby making these measurements directly traceable to the raw borehole data. The best-estimate groundsurface elevations with respect to the NAVD88 were taken from the Best Estimate Ground Surface Elevation database (dated June 25, 2008) where available and converted to English units.

These cross sections are intended to help illustrate the current interpretation of the lateral and vertical extent and variability of the major stratigraphic units (formation and member/facies associations) beneath the 200 West Area. Each borehole identified for inclusion in cross sections B-B' and F-F' was evaluated and included or excluded from the final cross section based on the set of borehole quality ranking criteria outlined in Table 3.1 (Point System for Prioritizing Borehole Data Analyses). These geologic cross sections were used to help verify the geologic contacts in the contacts database and to help evaluate and resolve anomalies and areas of high uncertainty in the geologic solid model.

\subsubsection{North-South Cross Section (B-B')}

Cross section B-B' (Appendix D) was constructed with a total of 84 boreholes. A generalized schematic of this cross section is presented in Figure 6.14. Twenty-six of the 84 boreholes (31\%) along this cross section have available logplot files, and 52 boreholes (62\%) have available geologic contact data. Figure 6.16 illustrates a cross section through the solid-earth geologic model (created using EarthVision) coincident with, and for comparison against, that of Figure 6.14 and Appendix D, cross section B-B'.

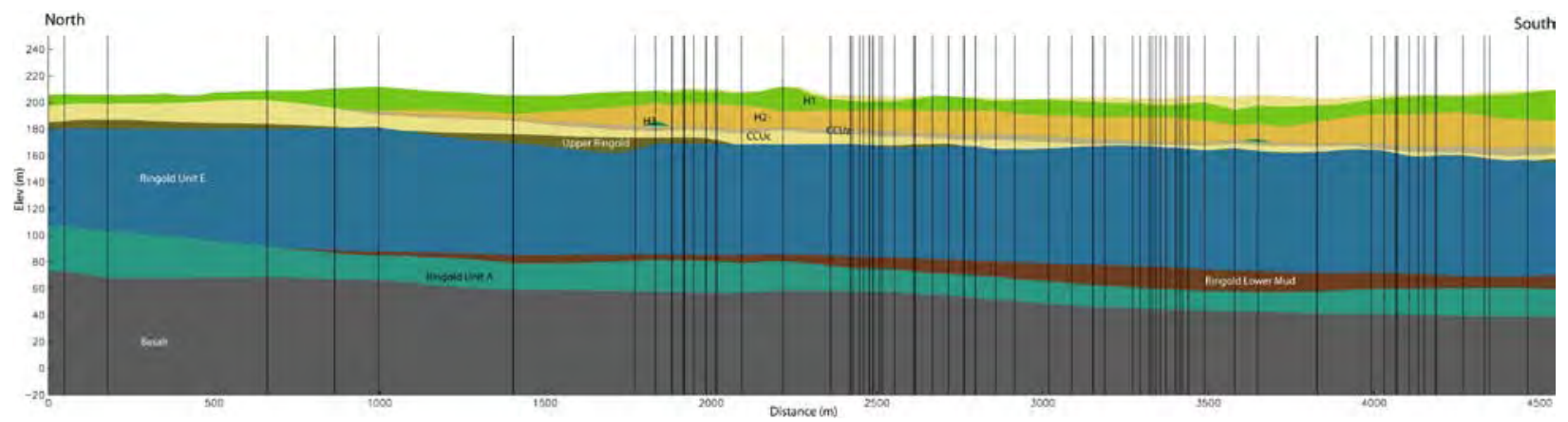

Figure 6.16. North-South Cross Section Through the Solid-Earth Geologic Model Coincident with That of Cross Section B-B' (Figure 6.14)

\footnotetext{
${ }^{1}$ LogPlot $^{\mathrm{TM}}$ is a trademark of RockWare Inc., Golden, Colorado.
} 


\subsubsection{East-West Cross Section (F-F')}

Cross section F-F' (Appendix D) was constructed with a total of 20 boreholes. A generalized schematic of this cross section is presented in Figure 6.15. Currently, 12 of the 20 boreholes (60\%) have available logplot files, and 12 boreholes (60\%) have available geologic contact data. Figure 6.17 illustrates a cross section through the solid-earth geologic model (crated using EarthVision) coincident with, and for comparison against, that of Figure 6.15 and Appendix D, cross section F-F'.

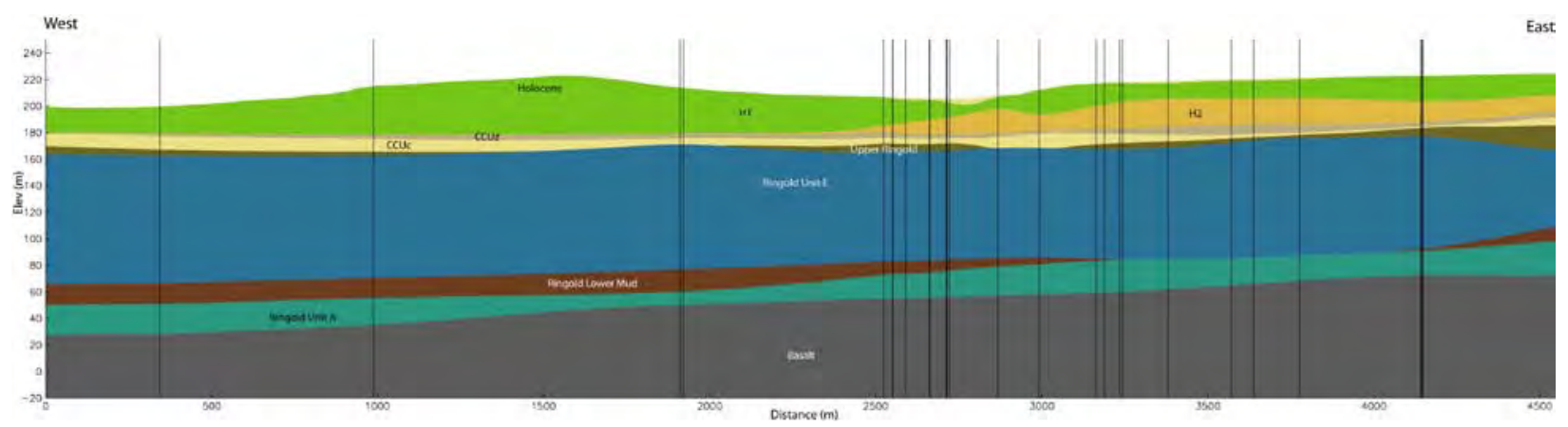

Figure 6.17. West-East Cross Section Through the Solid Earth Geologic Model Coincident with That of Cross Section F-F' (Figure 6.15) 


\subsection{Physical, Hydraulic, and Geochemical Properties}

A compilation of the existing physical, hydraulic, and geochemical properties for stratigraphic units and associated lithofacies defined in the 3D stratigraphic model can be found in Last et al. (2009). The hydrostratigraphy and associated flow and transport parameters are highly site-specific and are generally applicable to a select set of conditions under which the parameters were measured or estimated. Many physical, hydrologic, and geochemical factors affect these parameter values, including the depositional environment, particle size distribution, sedimentary structures, compaction and cementation, and sediment mineralogy. As a result, determining the appropriate flow and transport parameters for a specific application generally requires the expert judgment of a hydrogeologist or soil scientist familiar with the environmental conditions and the conditions under which the parameter values were measured or estimated and the needs of the model being constructed.

Petrologic, mineralogic, bulk rock geochemistry, and other geochemical properties of the subsurface geologic materials provide information on the provenance, stratigraphic correlation, and contaminant retardation properties of the stratigraphic units and intra-unit facies. A summary of the available petrologic, mineralogic, bulk rock geochemistry, and cation exchange data was partially documented by Mackley and Last (2003) and Xie et al. (2003). Efforts are in progress to develop a Hanford Site-wide database for this information (Mackley et al. 2008). A summary of these data relative to the stratigraphic and hydrostratigraphic units is presented below.

\subsection{Mineralogy, Petrology, and Bulk Rock Geochemistry}

Mineralogic data have been derived primarily from electron microprobe (EM), x-ray diffraction (XRD), or petrologic analyses. Bulk rock geochemistry data has primarily been derived from x-ray fluorescence spectrometry. Xie et al. (2003) suggest that there are significant differences between the Hanford and Ringold formations; however, there is also significant spatial variability within each formation.

\subsubsection{Hanford Formation}

The Hanford formation sediment consists of glaciofluvial materials deposited by Ice Age floods. The mineralogy of this sediment is highly variable, depending on grain size. Gravel-dominated sediment tends to have a high degree of rock fragments (mostly basaltic, with some plutonic, metamorphic, and detrital caliche fragments) (DOE 2002). Microprobe analysis of the sand and finer-grained fraction has found it to be dominated by quartz ( $18 \%$ to $67.1 \%$ by weight), plagioclase ( $5.1 \%$ to $41.5 \%$ ), and microcline (1.8\% to 30.1\%) (Tallman et al. 1979; Serne et al. 1993; Xie et al. 2003). Other dominant minerals include amphiboles up to $36.6 \%$, pyroxenes up to $27.5 \%$, mica (biotite/illite) up to $13.1 \%$, and calcite up to $6.5 \%$ by weight. Smectite clays represent a few weight percent of the bulk sand fraction (3.3\% to 5\% [Serne et al. 1993]) and generally dominate in the clay fraction (Tallman et al. 1979). Reidel (2004) reported chlorite concentrations generally less than $3 \mathrm{wt} \%$, except for one sample that had $8 \mathrm{wt} \%$ chlorite. 
Hanford formation sediment is typified as having low organic carbon content generally less than $0.1 \%$ by weight (Serne et al. 1993) and low-to-moderate cation exchange capacity (2.6 to 7.8 milliequivalents per 100 grams; Serne et al. 1993). The sediment has a slightly basic $\mathrm{pH}$ when wetted (Serne et al. 1993 found that the $\mathrm{pH}$ of saturation extract ranged from 7.66 to 8.17). Small amounts of detrital calcium carbonate (calcite) are common and can act as a weak buffer.

\subsubsection{Cold Creek Unit}

Much less mineralogy data are available for the Cold Creek unit. Tallman et al. (1979) found that the sediments they referred to as Early Palouse Soil are fairly similar in mineralogy to that of the Hanford formation sediments ( $25.3 \%$ to $29.4 \%$ quartz, $15.1 \%$ to $18.2 \%$ plagioclase, $15 \%$ to $17.8 \%$ microcline, $7.9 \%$ to $10 \%$ amphiboles, $1.3 \%$ to $12.5 \%$ micas) but generally are higher in calcite ( $8 \%$ to $8.8 \%$ ) and lack pyroxenes. Bjornstad (1990) found similar results for these fine-grained sediments but found that the carbonate-rich facies (referred to as the Plio-Pleistocene unit) consisted predominantly of calcium carbonate and/or sedimentary rock fragments, with lesser amounts of quartz and feldspars. Thin beds of caliche with calcite predominate, and variable amounts of ferric oxide exist in the 200 West Area in the Cold Creek unit just above the Ringold Formation.

\subsubsection{Ringold Formation}

Xie et al. (2003) found significant differences in electron microprobe and petrographic results between the Hanford and Ringold formations. The Ringold Formation sediment is generally higher in quartz than the Hanford formation but lower in plagioclase and pyroxene. Deeper within the Ringold Formation, calcic and ferric oxide cements are often present. The cementing can alter significantly the permeability of the otherwise coarse-grained Ringold sediment.

\subsection{Contaminant Distribution Coefficients}

Most recent Hanford Site assessments have primarily relied on, or built on, the generic distribution coefficients assembled by Last et al. (2006). Thus, these values provide the most logical basis for Hanford-specific $\mathrm{K}_{\mathrm{d}}$ values for use with RESRAD (Last et al. 2009). However, these generic Hanford Site $K_{d}$ values should be used only in the absence of waste-site-specific data.

\subsection{Limitations and Data Gaps}

The location of mineralogic and geochemical samples should be correlated to the geologic model to reassess the units to which they are assigned. 


\subsection{Limitations and Uncertainty}

Several sources of error and limitations are associated with compilation of so many diverse sets of stratigraphic contacts and the assignment of physical, hydrologic, and geochemical properties. These data compilations and databases are evolving, and different versions of the databases have been used in different parts of this analysis. However, the differences among these database versions are relatively minor and are not believed to be significant to the overall analysis. These data compilations and databases and are subject to future refinement as additional data are incorporated and as further evaluations are made.

\subsection{Uncertainty in Stratigraphic Interpretations}

Borehole geologic data are of variable quality, and a number of sources of uncertainty are associated with these data and interpretation of the geologic units, their top and bottom contacts, their lateral continuity, and their thicknesses.

\subsubsection{Identification of Geologic Units and Contacts}

The principal source of uncertainty for identification of geologic units and their contacts is the descriptive quality of the drilling, sampling, and logging techniques used during borehole drilling, as well as the methods and materials used in well construction. The variable quality or lack of availability of borehole geophysical logs and laboratory data from borehole samples also contribute to this uncertainty. Many boreholes installed prior to the 1980s were drilled without a well site geologist present to describe the drill cuttings and samples. For these boreholes, only drillers' logs are available, and their quality varies greatly. Furthermore, varying quality of descriptions of subtle differences and gradational changes among geologic facies and across stratigraphic units can hamper reliable spatial correlation of sediment packages and individual facies.

As a result of the variability of data and the experience and professional judgment of the different investigators, many of the same geologic contacts have been picked at slightly different locations by different investigators. Different investigators may use different criteria for choosing contacts, depending on the objectives of the specific project (e.g., geologic in nature or hydrologic). Therefore, contact selection can be subjective and inconsistent. In some cases, the difference in contact elevation may be attributable to differences in the ground-surface elevations used by the different investigators.

\subsubsection{Vertical Survey and Depth Control}

Uncertainties in contact estimates can be derived from poor vertical survey and depth control. Sources of uncertainty include poorly documented information such as ground-surface elevation at the time of drilling and sampling, the reference point elevation at the time of borehole geophysical logging or other measurements, and the accuracy of depth measurements. Multiple survey estimates for some wells

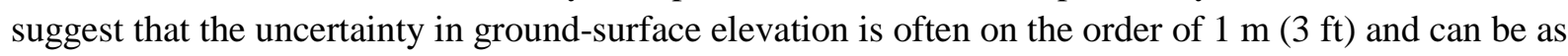

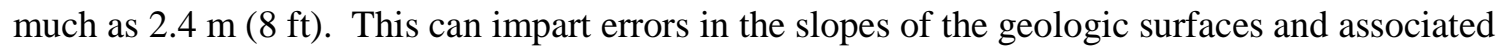
extrapolation of the 3D configuration of the stratigraphic unit. 


\subsubsection{Depth and Thickness of Sedimentary Units}

The spacing and accuracy of depth-discrete observations and samples also can influence the interpretation of the depth and thickness of geologic units. Drill cuttings and samples have routinely been collected at 1.5-m (5-ft) intervals. However, the accuracy of depth measurements for these samples and observations is rather uncertain due to the variability in measurement techniques used by various drillers. The resulting uncertainty associated with interpretation of the depth and thicknesses of geologic units is estimated to be within the range of 0.7 to $3 \mathrm{~m}$ (2.5 to $10 \mathrm{ft}$ ). Borehole geophysical logging data can help to significantly reduce depth uncertainties for geologic units with distinct geophysical signatures.

A minor source of uncertainty contributing to the accuracy of depth measurements is the straightness and plumpness of the borehole. While small deviations can have a significant effect on water-level measurements, this source of uncertainty is deemed to be rather minor relative to the scale of borehole sampling because most boreholes have been shown to have only minor deviations when casing liners and/or groundwater pumps have been installed. 


\subsection{References}

Anderson MP. 1990. “Aquifer Heterogeneity-A Geological Perspective.” In Proceedings of the Fifth Canadian/American Conference on Hydrogeology: Parameter Identification and Estimation for Aquifer and Reservoir Characterization, pp. 3-22. September 18-20, 1990, Calgary, Alberta. National Ground Water Association, Westerville, Ohio.

Baker VR, BN Bjornstad, AJ Busacca, KR Fecht, EP Kiver, UL Moddy, JG Rigby, DF Stradling, and AM Tallman. 1991. "Quaternary Geology of the Columbia Plateau.” Vol. K-2, Chapter 8 in The Geology of North America, Quaternary Nonglacial Geology: Conterminous U.S., pp. 215-250. Geological Society of America Meeting, Boulder, Colorado.

Barton BR. 1999. “Some Notable Finds of Columbian Mammoths from Washington State.” Washington Geology 27(2/3/4).

Bjornstad BN. 1984. Suprabasalt Stratigraphy Within and Adjacent to the Reference Repository Location. SD-BWI-DP-039, Rockwell Hanford Operations, Richland, Washington.

Bjornstad BN. 1990. Geohydrology of the 218-W-5 Burial Ground, 200 West Area, Hanford Site. PNNL-7336, Pacific Northwest National Laboratory, Richland, Washington.

Bjornstad BN. 2004. Geologic Contacts Database for the 200 Areas of the Hanford Site. WMP-22817, Rev. 0, Fluor Hanford, Inc., Richland, Washington.

Bjornstad BN. 2006. On the Trail of the Ice Age Floods. Keokee Co. Publishing, Inc., Sandpoint, Idaho.

Bjornstad BN and DC Lanigan. 2007. Geologic Descriptions for the Solid-Waste Low Level Burial Grounds. PNNL-16887, Pacific Northwest National Laboratory, Richland, Washington.

Brown DJ. 1959. Subsurface Geology of the Hanford Separation Areas. HW-61780, General Electric Company, Richland, Washington.

Brown DJ. 1960. An Eolian Deposit Beneath 200-West Area. HW-67549, General Electric Company, Richland, Washington.

Camp VE, ME Ross, and WE Hanson. 2003. "Genesis of Flood Basalts and Basin and Range Volcanic Rocks from Steens Mountain to the Malheur River Gorge, Oregon.” Geological Society of America Bulletin 115(1):105-128.

Connelly MP, JV Borghese, CD Delaney, BH Ford, JW Lindberg, and SJ Trent. 1992a. Hydrogeologic Model for the 200 East Groundwater Aggregate Area. WHC-SD-EN-TI-019, Westinghouse Hanford Company, Richland, Washington.

Connelly MP, BH Ford, and JV Borghese. 1992b. Hydrogeologic Model for the 200 West Groundwater Aggregate Area. WHC-SD-EN-TI-014, Rev. 0, Westinghouse Hanford Company, Richland, Washington.

DOE. 2002. Standardized Stratigraphic Nomenclature for Post-Ringold Formation Sediments Within the Central Pasco Basin. DOE/RL-2002-39, Rev. 0, U.S. Department of Energy, Richland Operations Office, Richland, Washington. 
Fecht KR, RP Reidel, and AM Tallman. 1987. "Paleodrainage of the Columbia River System on the Columbia Plateau of Washington State - A Summary.” In Selected Papers on the Geology of Washington, Bulletin 77, pp. 219-248. Division of Geology and Earth Resources, Washington State Department of Natural Resources, Olympia, Washington.

Fogg GE, CD Noyes, and SF Carle. 1989. “Geologically Based Model of Heterogeneous Hydraulic Conductivity in an Alluvial Setting.” Hydrogeology Journal 6:131-143.

Gephart RE. 2003. Hanford - A Conversation About Nuclear Waste and Cleanup. Battelle Press, Columbus, Ohio.

Gustafson EP. 1978. The Vertebrate Faunas of the Pliocene Ringold Formation, Southcentral Washington. Bulletin 23, University of Oregon Museum of Natural History, Eugene, Oregon.

Heinz J, S Kleineidam, G Teutsch, and T Aigner. 2003. "Heterogeneity Patterns of Quaternary Glaciofluvial Gravel Bodies (SW Germany): Application to Hydrogeology.” Sedimentary Geology 158:1-23.

Last GV, BN Bjornstad, MP Bergeron, DW Wallace, DR Newcomer, JA Schramke, MA Chamness, CS Cline, SP Airhart, and JS Wilbur. 1989. Hydrogeology of the 200 Areas Low-Level Burial Grounds An Interim Report. PNL-6820, Vol. 1 and 2, Pacific Northwest Laboratory, Richland, Washington.

Last GV, RD Mackley, and DC Lanigan. 2006. Borehole Geologic Data for the 216-Z Crib Facilities A Status of Data Assembled through the Hanford Borehole Geologic Information System (HBGIS). PNNL-16103, Rev. 0, Pacific Northwest National Laboratory, Richland, Washington.

Last GV, CJ Murray, DA Bush, EC Sullivan, ML Rockhold, RD Mackley, and BN Bjornstad. 2007. "Standardization of Borehole Data to Support Vadose Zone Flow and Transport Modeling." Vadose Zone Journal 6(4):906-912.

Last GV, ML Rockhold, CJ Murray, and KJ Cantrell. 2009. Selection and Traceability of Parameters To Support Hanford-Specific RESRAD Analyses. PNNL-18564, Pacific Northwest National Laboratory, Richland, Washington.

Lindsey KA. 1991. Geologic Setting of the 200 West Area: An Update. WHC-SD-EN-TI-008, Westinghouse Hanford Company, Richland, Washington.

Lindsey KA. 1992. Geologic Setting of the 200 East Area: An Update. WHC-SD-EN-TI-012, Westinghouse Hanford Company, Richland, Washington.

Lindsey KA. 1995. Miocene- to Pliocene-Aged Suprabasalt Sediments of the Hanford Site, SouthCentral Washington. BHI-00184, Bechtel Hanford, Inc., Richland, Washington.

Lindsey KA. 1996. The Miocene to Pliocene Ringold Formation and Associated Deposits of the Ancestral Columbia River System, South-Central Washington and North-Central Oregon. Open-File Report 96-8, Division of Geology and Earth Resources, Washington State Department of Natural Resources, Olympia, Washington. 
Lindsey KA, SE Kos, and KD Reynolds. 2000. Vadose Zone Geology of Boreholes 299-W22-50 and 299-W23-19 S-SX Waste Management Area Hanford Site, South-Central Washington. RPP-6149, Rev. 0, CH2M HILL Hanford Group, Inc., Richland, Washington.

Lindsey KA, KD Reynolds, and SE Kos. 2001. Vadose Zone Geology of Boreholes 299-E33-45 and 299-E33-46 B-BX-BY Waste Management Area Hanford Site, South-Central Washington. RPP-8681, CH2M HILL Hanford Group, Inc., Richland, Washington.

Lindsey KA, JL Slate, GK Jaeger, KJ Swett, and RB Mercer. 1994. Geologic Setting of the Low-Level Burial Grounds. WHC-SD-EN-TI-290, Rev. 0, Westinghouse Hanford Company, Richland, Washington.

Mackley RD and G Last. 2003. "Mineralogical and Bulk-Rock Geochemical Signatures of Ringold and Hanford Formation Sediments.” Journal of Undergraduate Research 3:107. Office of Science, U.S. Department of Energy, Washington, D.C.

Mackley RD, JA Serkowski, and G Last. 2008. Status Report on the Creation of a Preliminary Data Model and Dictionary for a New Petrologic Database. PNNL-17663, Pacific Northwest National Laboratory, Richland, Washington.

McGhan VL. 1989. Hanford Wells. PNL-6907, Pacific Northwest Laboratory, Richland, Washington.

Myers CW, SM Price, JA Caggiano, MP Cochran, WJ Czimer, NJ Davidson, RC Edwards, KR Fecht, GE Holmes, MG Jones, JR Kunk, RD Landon, RK Ledgerwood, JT Lillie, PE Long, TH Mitchell, EH Price, RP Reidel, and AM Tallman. 1979. Geologic Studies of the Columbia Plateau - A Status Report: October 1979. RHO-BWI-ST-4, Rockwell Hanford Operations, Richland, Washington.

Newcomb RC, JR Strand, and FJ Frank. 1972. Geology and Ground-Water Characteristics of the Hanford Reservation of the U.S. Atomic Energy Commission, Washington. Professional Paper 717, U.S. Geological Survey, Washington, D.C.

O’Conner JE and JE Costa. 2004. The World's Largest Floods, Past and Present - Their Causes and Magnitudes. Circular 1254, U.S. Geological Survey, Washington, D.C.

Oostrom M, ML Rockhold, PD Thorne, GV Last, and MJ Truex. 2006. Carbon Tetrachloride Flow and Transport in the Subsurface of the 216-Z-18 Crib and 216-Z-1A Tile Field at the Hanford Site: Multifluid Flow Simulations and Conceptual Model Update. PNNL-16198, Pacific Northwest National Laboratory, Richland, Washington.

Pluhar CJ, BN Bjornstad, RP Reidel, RS Cole, and PB Nelson. 2006. “Magnetostratigraphic Evidence from the Cold Creek Bar for Onset of Ice-Age Cataclysmic Floods in Eastern Washington During the Early Pleistocene.” Quaternary Research 65:123-135.

PSPL. 1981. Skagit/Hanford Nuclear Project, Preliminary Safety Analysis Report, Vol. 1. Puget Sound Power and Light Company, Tacoma, Washington.

Reidel SP. 2004. Geologic Data Package for 2005 Integrated Disposal Facility Waste Performance Assessment. PNNL-14586, Pacific Northwest National Laboratory, Richland, Washington. 
Reidel SP, NP Campbell, KR Fecht, and KA Lindsey. 1994. "Late Cenozoic Structure and Stratigraphy of South-Central Washington.” In Regional Geology of Washington State, Bulletin 80, pp. 159-180.

Division of Geology and Earth Resources, Washington State Department of Natural Resources, Olympia, Washington.

Reidel SP and MA Chamness. 2007. Geology Data Package for the Single-Shell Tank Waste Management Areas at the Hanford Site. PNNL-15955, Rev. 1, Pacific Northwest National Laboratory, Richland, Washington. Available at http://www.pnl.gov/main/publications/external/technical_reports/ PNNL-15955rev1.pdf.

Reidel SP, TL Tolan, PR Hooper, MH Beeson, KR Fecht, RD Bentley, and JL Anderson. 1989. “The Grande Ronde Basalt, Columbia River Basalt Group; Stratigraphic Descriptions and Correlations in Washington, Oregon, and Idaho.” In Volcanism and Tectonism in the Columbia River Flood-Basalt Province, Special Paper 239, pp. 21-53. Geological Society of America, Boulder, Colorado.

Rohay VJ, KJ Swett, and GV Last. 1994. 1994 Conceptual Model of the Carbon Tetrachloride Contamination in the 200 West Area at the Hanford Site. WHC-SD-EN-TI-248, Rev. 0, Westinghouse Hanford Company, Richland, Washington.

Serne RJ, BN Bjornstad, DG Horton, DC Lanigan, CW Lindenmeier, MJ Lindberg, RE Clayton, VL LeGore, RD Orr, IV Kutnyakov, SR Baum, KN Geiszler, MM Valenta, and TS Vickerman. 2004a. Characterization of Vadose Zone Sediments Below the TX Tank Farm: Boreholes C3830, C3831, C3832 and RCRA Borehole 299-W10-27. PNNL-14594, Pacific Northwest National Laboratory, Richland, Washington.

Serne RJ, BN Bjornstad, DG Horton, DC Lanigan, HT Schaef, CW Lindenmeier, MJ Lindberg, RE Clayton, VL LeGore, KN Geiszler, SR Baum, MM Valenta, IV Kutnyakov, TS Vickerman, RD Orr and CF Brown. 2004b. Characterization of Vadose Zone Sediments Below the T Tank Farm: Boreholes C4104, C4105, 299-W10-196, and RCRA Borehole 299-W11-39. PNNL-14849, Pacific Northwest National Laboratory, Richland, Washington.

Serne RJ, BN Bjornstad, HT Schaef, BA Williams, DC Lanigan, DG Horton, RE Clayton, AV Mitroshkov, VL LeGore, MJ O’Hara, CF Brown, KE Parker, IV Kutnyakov, JN Serne, G Last, SC Smith, CW Lindemeier, JM Zachara, and DB Burke. 2002a. Characterization of Vadose Zone Sediment: Uncontaminated RCRA Borehole Core Samples and Composite Samples. PNNL-13757-1, Pacific Northwest National Laboratory, Richland, Washington.

Serne RJ, JL Conca, VL LeGore, KJ Cantrell, CW Lindenmeier, JA Campbell, JE Amonette, and MI Wood. 1993. Solid Waste Leach Characteristics and Contaminant-Sediment Interactions. Volume 1: Batch Leach and Adsorption Tests and Sediment Characterization. PNL-8889, Pacific Northwest Laboratory, Richland, Washington.

Serne RJ, G Last, HT Schaef, DC Lanigan, CW Lindenmeier, CC Ainsworth, RE Clayton, VL LeGore, MJ O’Hara, CF Brown, RD Orr, IV Kutnyakov, TC Wilson, KB Wagnon, BA Williams, and DS Burke. 2002b. Characterization of Vadose Zone Sediment: Borehole 41-09-39 in the S-SX Management Area. PNNL-13757-3, Pacific Northwest National Laboratory, Richland, Washington.

Serne RJ, GV Last, HT Schaef, DC Lanigan, CW Lindenmeier, CC Ainsworth, RE Clayton, VL LeGore, MJ O’Hara, CF Brown, RD Orr, IV Kutnyakov, TC Wilson, KB Wagnon, BA Williams, and DS Burke. 2002c. Characterization of Vadose Zone Sediment: Slant Borehole SX-108 in the S-SX Waste Management Area. PNNL-13757-4, Pacific Northwest National Laboratory, Richland, Washington. 
Serne RJ, HT Schaef, BN Bjornstad, DC Lanigan, GW Gee, CW Lindemeier, RE Clayton, VL LeGore, RD Orr, MJ O’Hara, CF Brown, GV Last, IV Kutnyakov, DS Burke, TC Wilson, and BA Williams. 2002d. Characterization of Vadose Zone Sediment: Borehole 299-W23-19 [SX-115] in the S-SX Waste Management Area. PNNL-13757-2, Pacific Northwest National Laboratory, Richland, Washington.

Sexton SM. 2008. Borehole Summary Report for the Installation of Wells 299-W11-88 (C5572), 699-4369 (C5573) and 699-45-69C (C5574) for the 200-ZP-1 Operable Unit, FY 2007. SGW-37703, Rev. 0, CH2M HILL Plateau Remediation Company, Richland, Washington.

Swanson DA and TL Wright. 1979. "Paleogeography of Southeast Washington During the Middle and Late Miocene Based on the Distribution of Intracanyon Basalt Flows (Abstract).” In Cenozoic Paleogeography of the Western United States, Pacific Coast Paleogeography Symposium 3, p. 331. Society of Economic Paleontologists and Mineralogists, Pacific Section, Los Angeles, California.

Swanson DA, JL Anderson, RD Bentley, VE Camp, JN Gardner, and TL Wright. 1979a. Reconnaissance Geologic Map of the Columbia River Basalt Group in Eastern Washington and Northern Idaho. Open File Report 79-1363, U.S. Geological Survey, Reston, Virginia.

Swanson DA, TL Wright, PR Hooper, and RD Bentley. 1979b. Revisions in Stratigraphic Nomenclature of the Columbia River Basalt Group. Bulletin 1457-G, U.S. Geological Survey, Reston, Virginia.

Tallman AM, KR Fecht, MC Marratt, and GV Last. 1979. Geology of the Separation Areas, Hanford Site, South-Central Washington. RHO-ST-23, Rockwell Hanford Operations, Richland, Washington.

Tallman AM, JT Lillie, and KR Fecht. 1981. "Suprabaslt sediments of the Cold Creek Syncline Area.” In Subsurface Geology of the Cold Creek Syncline, CW Myers and SM Price (eds). RHO-BWI-ST-14, Rockwell Hanford Operations, Richland, Washington.

Thompson A and BN Taylor. 2008. Guide for Use of the International System of Units (SI). NIST Special Publication 811, 2008 Edition, National Institute of Standards and Technology, Gaithersburg, Maryland.

Thorne PD, MP Bergeron, MD Williams, and VL Freedman. 2006. Groundwater Data Package for Hanford Assessments. PNNL-14753, Rev. 1, Pacific Northwest National Laboratory, Richland, Washington.

Waitt RB. 1994. "Scores of Gigantic, Successively Smaller Lake Missoula Floods Through Channeled Scabland and Columbia Valley." In Geological Field Trips in the Pacific Northwest: 1994 Geologic Society of America Meeting, pp. 1K-1 to 1K-88. Geological Society of America Meeting, Boulder, Colorado.

Waitt RB and DA Swanson. 1987. “Geomorphic Evolution of the Columbia Plain and River.” In Geomorphic Systems of North America (Centennial Special, Vol 2), WL Graf (ed), pp. 403-416. Geological Society of America, Boulder, Colorado.

Williams BA, BN Bjornstad, R Schalla, and WD Webber. 2000. Revised Hydrogeology for the Suprabasalt Aquifer System, 200-East Area and Vicinity, Hanford Site, Washington. PNNL-12261, Pacific Northwest National Laboratory, Richland, Washington. 
Williams BA, BN Bjornstad, R Schalla, and WD Webber. 2002. Revised Hydrogeology for the Suprabasalt Aquifer System, 200-West Area and Vicinity. PNNL-13858, Pacific Northwest National Laboratory, Richland, Washington.

Wood MI, R Schalla, BN Bjornstad, and SM Narbutovskih. 2000. Subsurface Conditions Description of the B-BX-BY Waste Management Area. HNF-5507, Rev. 0, Fluor Hanford, Richland, Washington.

Wood MI, TE Jones, R Schalla, BN Bjornstad, and FN Hodges. 2001. Subsurface Conditions Description of the T and TX-TY Waste Management Areas. RPP-7123, Revision 0, CH2M HILL Hanford Group, Inc., Richland, Washington.

Xie Y, CJ Murray, GV Last, and RD Mackley. 2003. Mineralogical and Bulk-Rock Geochemical Signatures of Ringold and Hanford Formation Sediments. PNNL-14202, Pacific Northwest National Laboratory, Richland, Washington. 


\section{Appendix A}

Stratigraphic Contacts for the $\mathbf{2 0 0}$ West Area and Vicinity 


\section{Appendix A}

\section{Stratigraphic Contacts for the 200 West Area and Vicinity}

Stratigraphic contact data ${ }^{1}$ were taken from an electronic database of contact information compiled from published reports as well as some unpublished data, including new or revised interpretations made specifically for this report. This database contains nearly 1,190 records representing stratigraphic contact information for 446 different boreholes. Only the contact depths (in feet below ground surface) are provided here. The source used as the basis for the vertical location of these stratigraphic contacts in each well is identified in the "Source" column (see Table 5.2 for explanation). The source information was used to identify a principal investigator and the date on which the information was published.

Where multiple depths were recorded for a given contact in a given borehole, a subjective ranking and evaluation was made to select the best-estimate contact depths for each borehole (see column "Rank/Priority”). Selection of the best-estimate contacts was based in part on a relative ranking of the traceability and defensibility of the contact data sources:

1 - Reported contacts are directly traceable to raw borehole data (e.g., through summary logs with contacts) and firsthand geologic interpretation (e.g., cross sections, structure contour maps).

2 - Reported contacts are indirectly traceable to raw borehole data (i.e., no summary logs) but are represented in firsthand geologic interpretation.

3 - Reported contacts are not readily traced to raw borehole data or firsthand geologic interpretation (e.g., data and/or interpretations taken from other documents).

4 - Unpublished contact data where no other data are available from that principal investigator(s).

5 - Unpublished contact data that have been superseded by other published data by the same principal investigator(s).

Note that most of these best-estimate picks were taken from unpublished work by Bjornstad, with the source identified as "Bjornstad08" and the date published as "This Report." Other best estimates made specifically for this study were identified with a specific record and existing source. Where the contacts were defined specifically for this report, they were similarly identified by the geologist picking the contacts (e.g., "Last08”) and with the date published listed as “This Report.” Note that these newly developed contact sets were not ranked.

\footnotetext{
${ }^{1}$ The database is included in an Excel file, 200 W Contact Depths_2009-08-17.xls, in this Appendix A subfolder.
} 


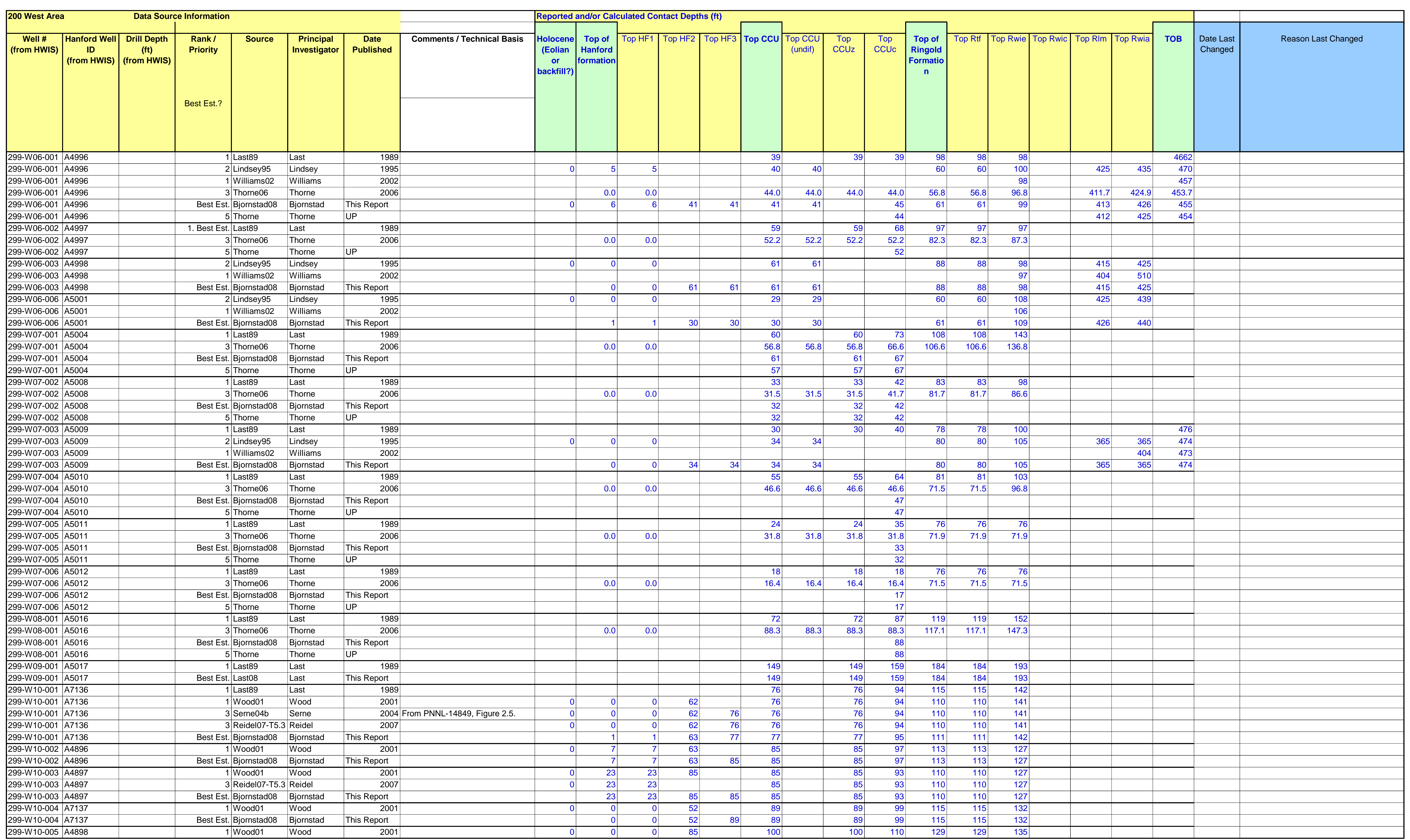




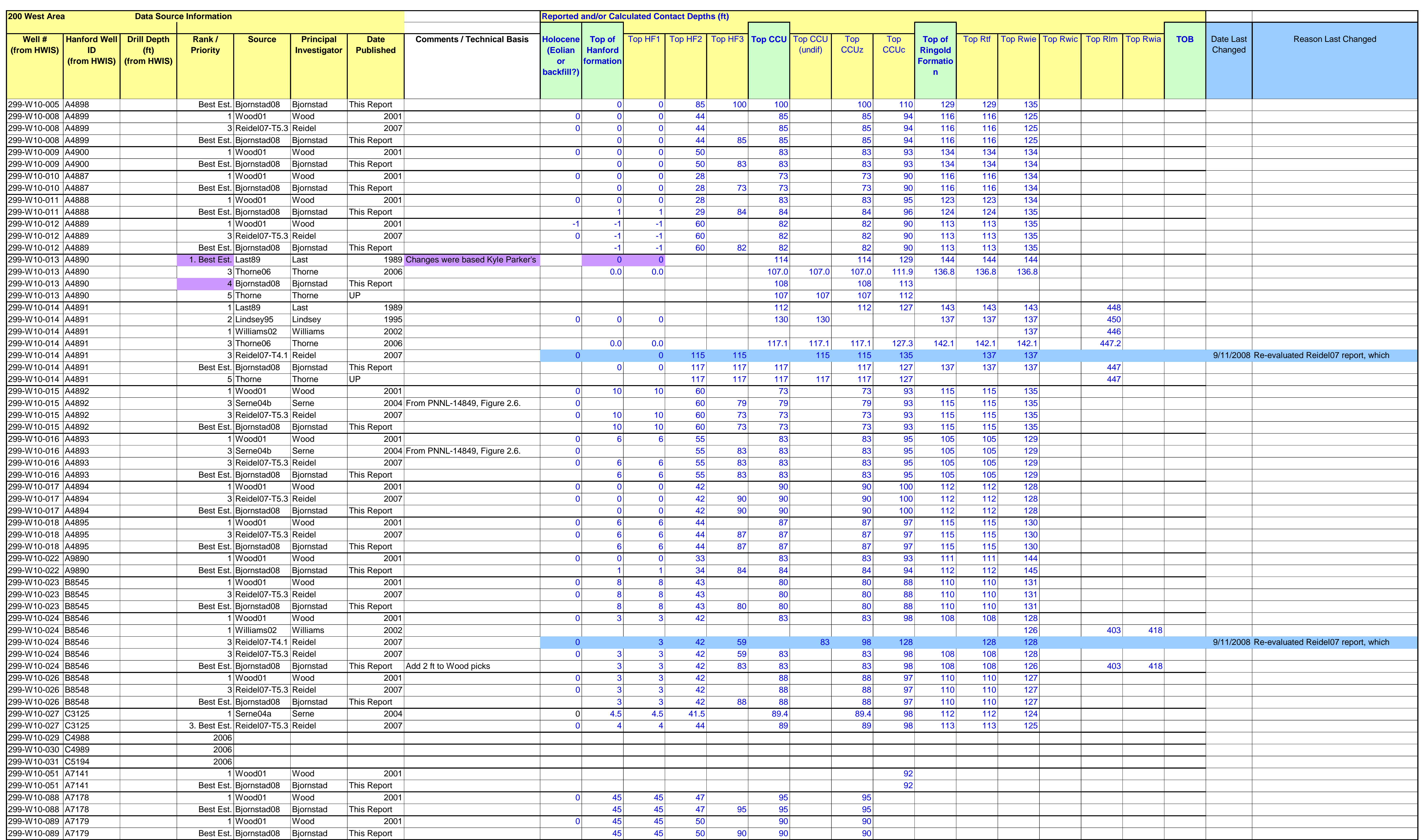




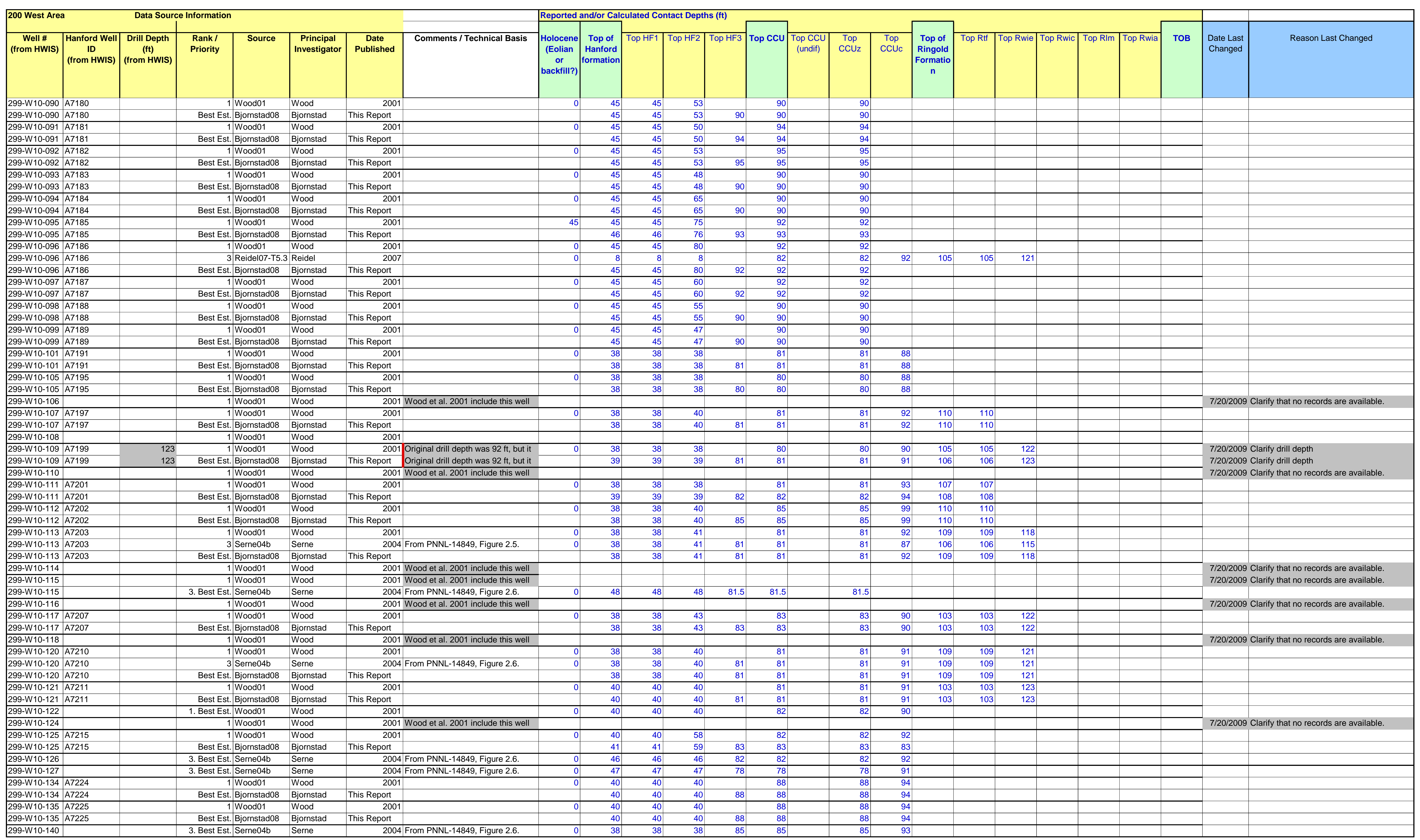




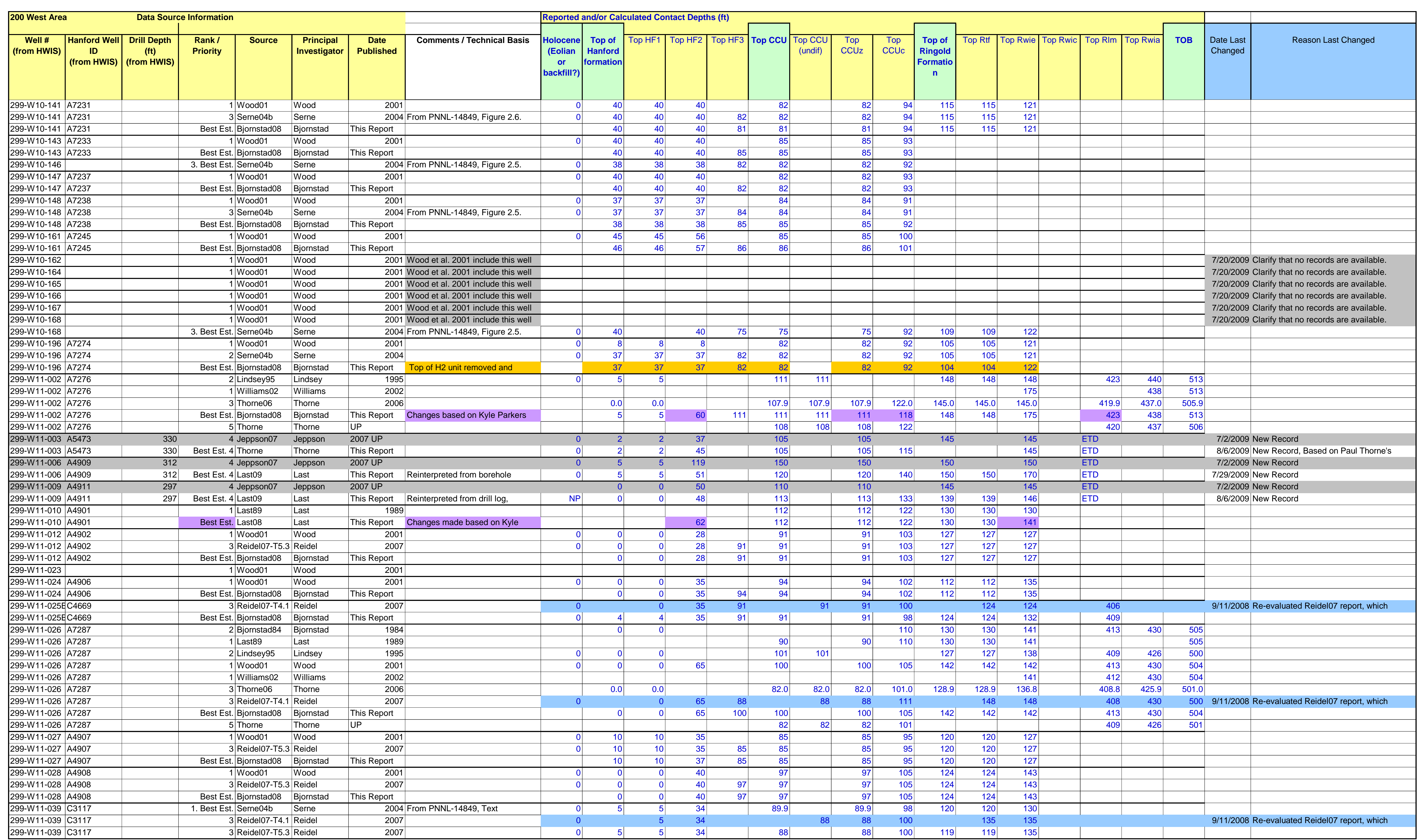




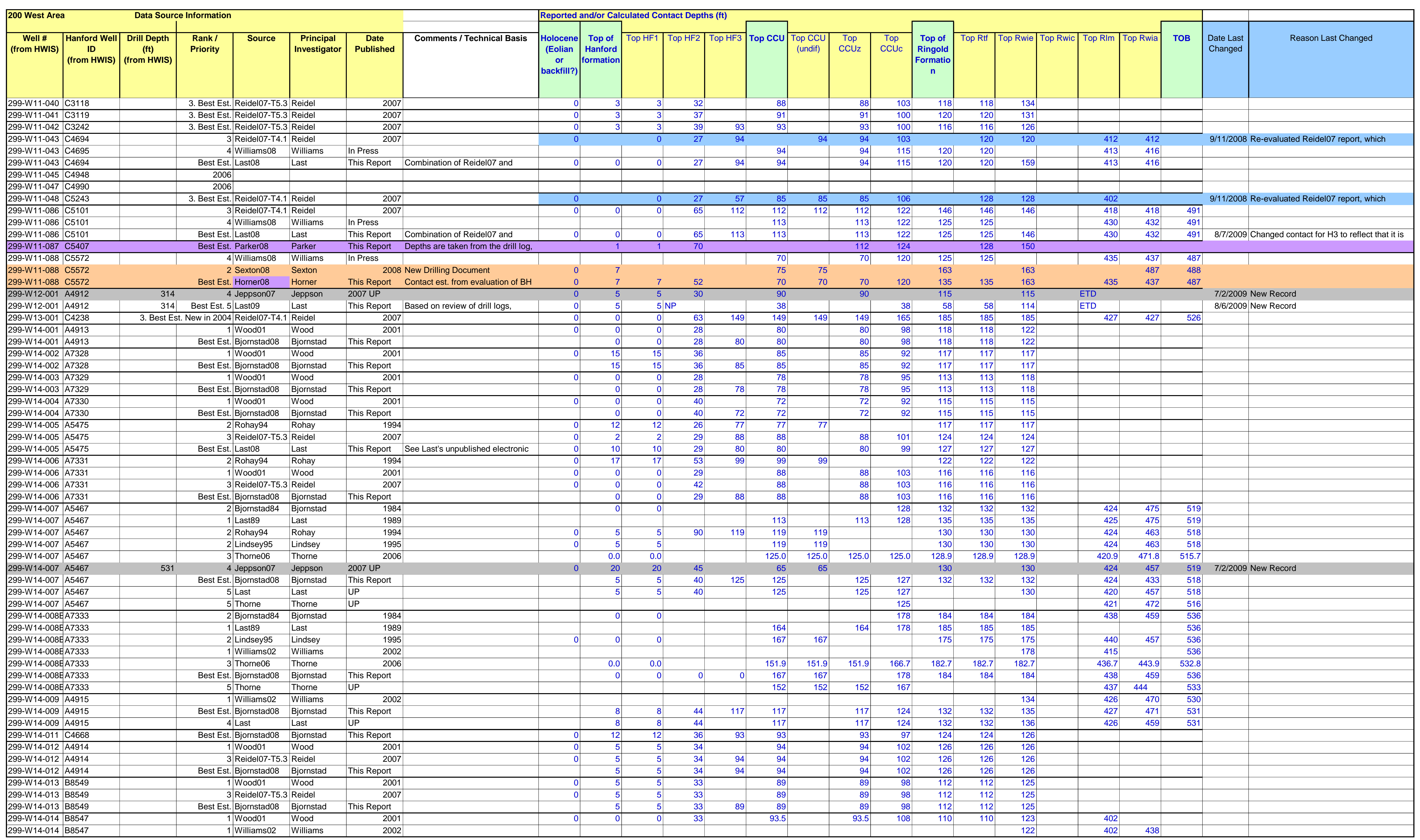




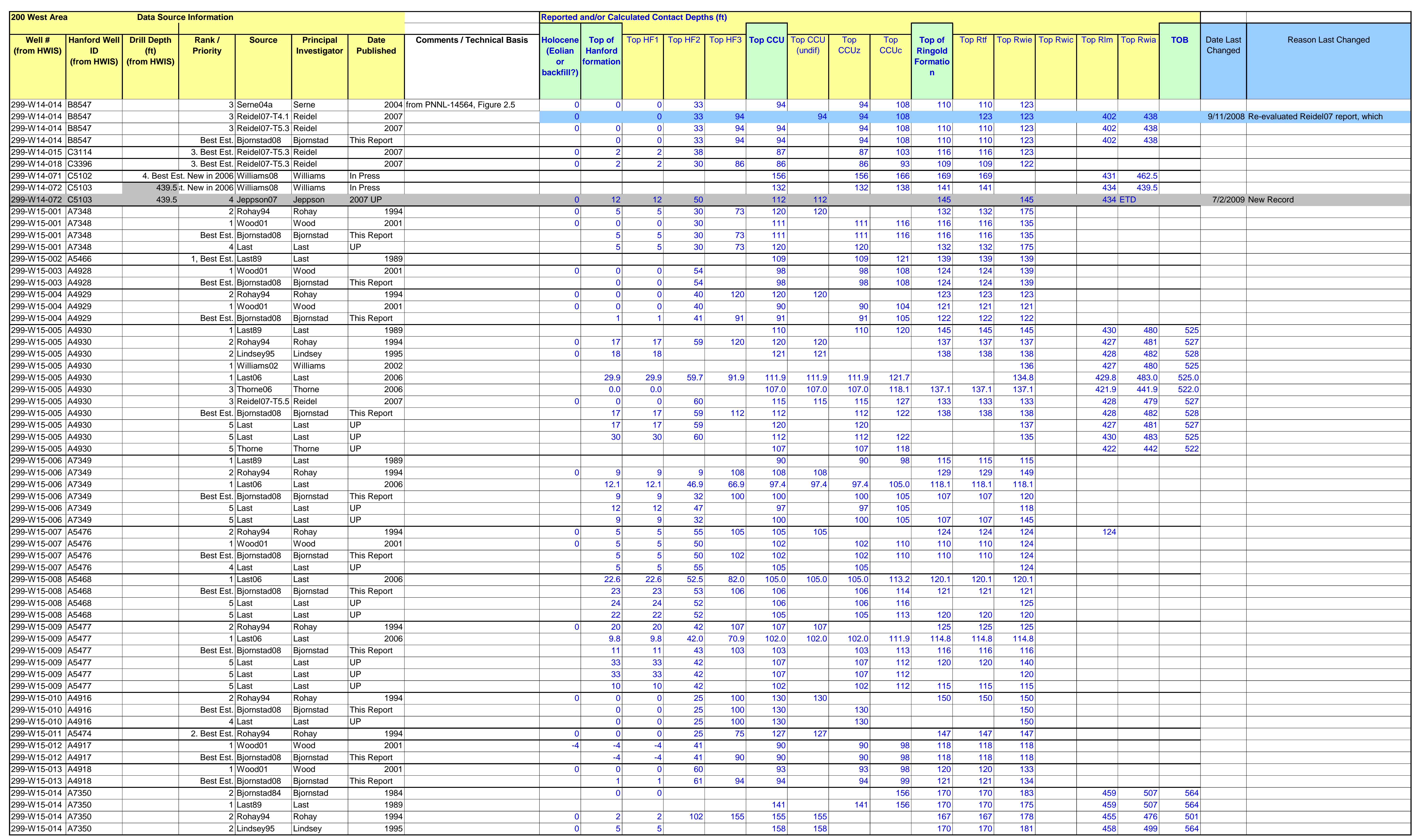




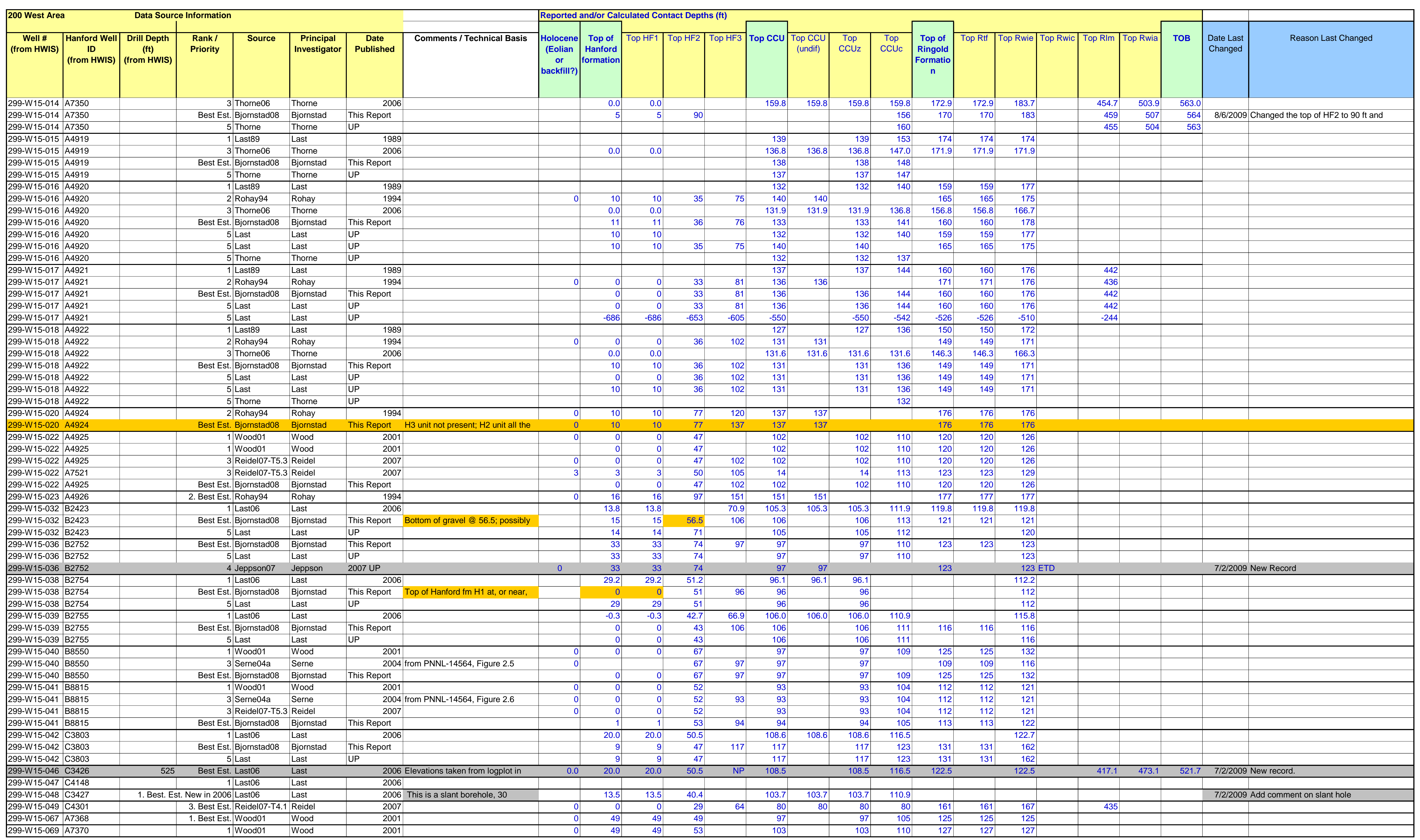




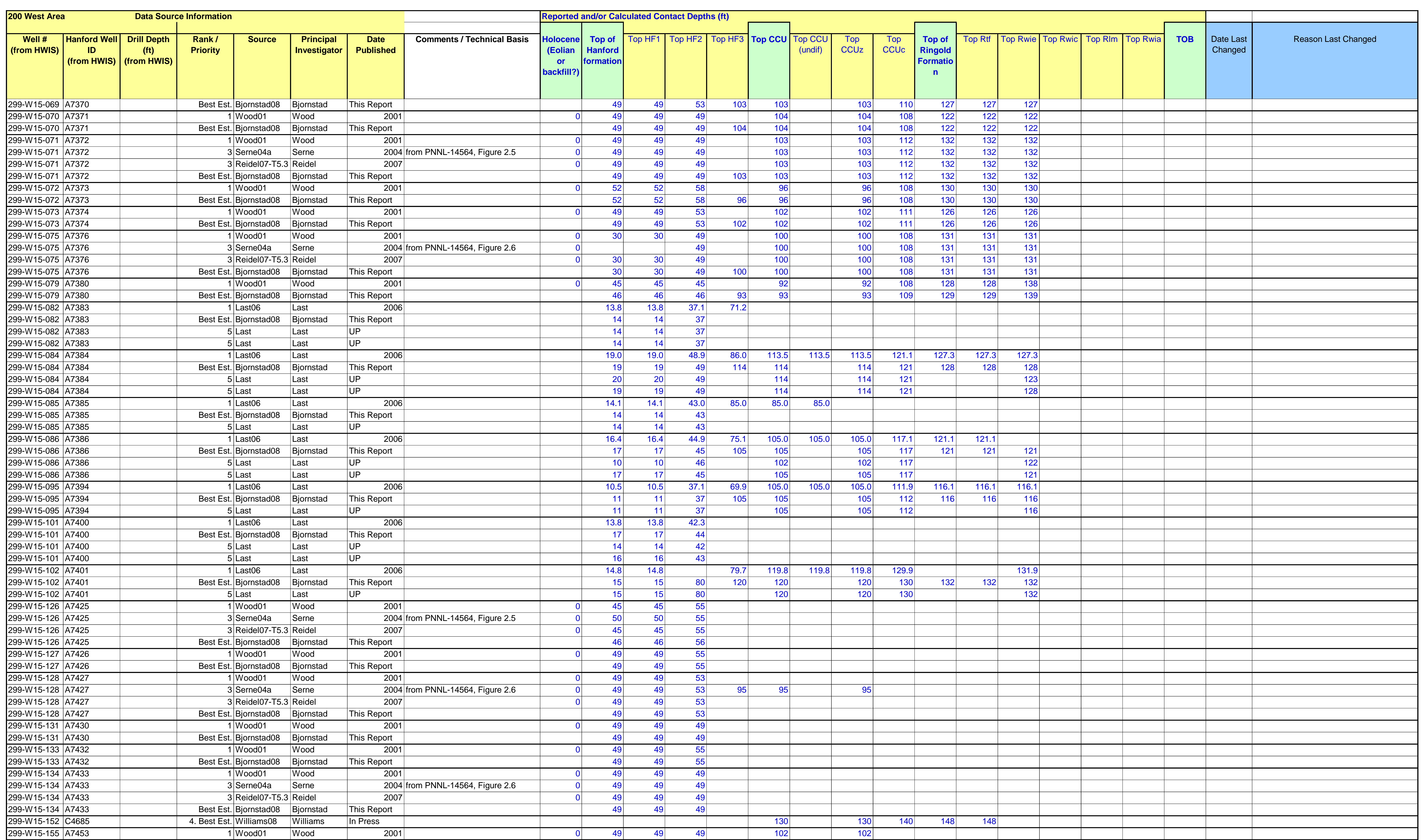




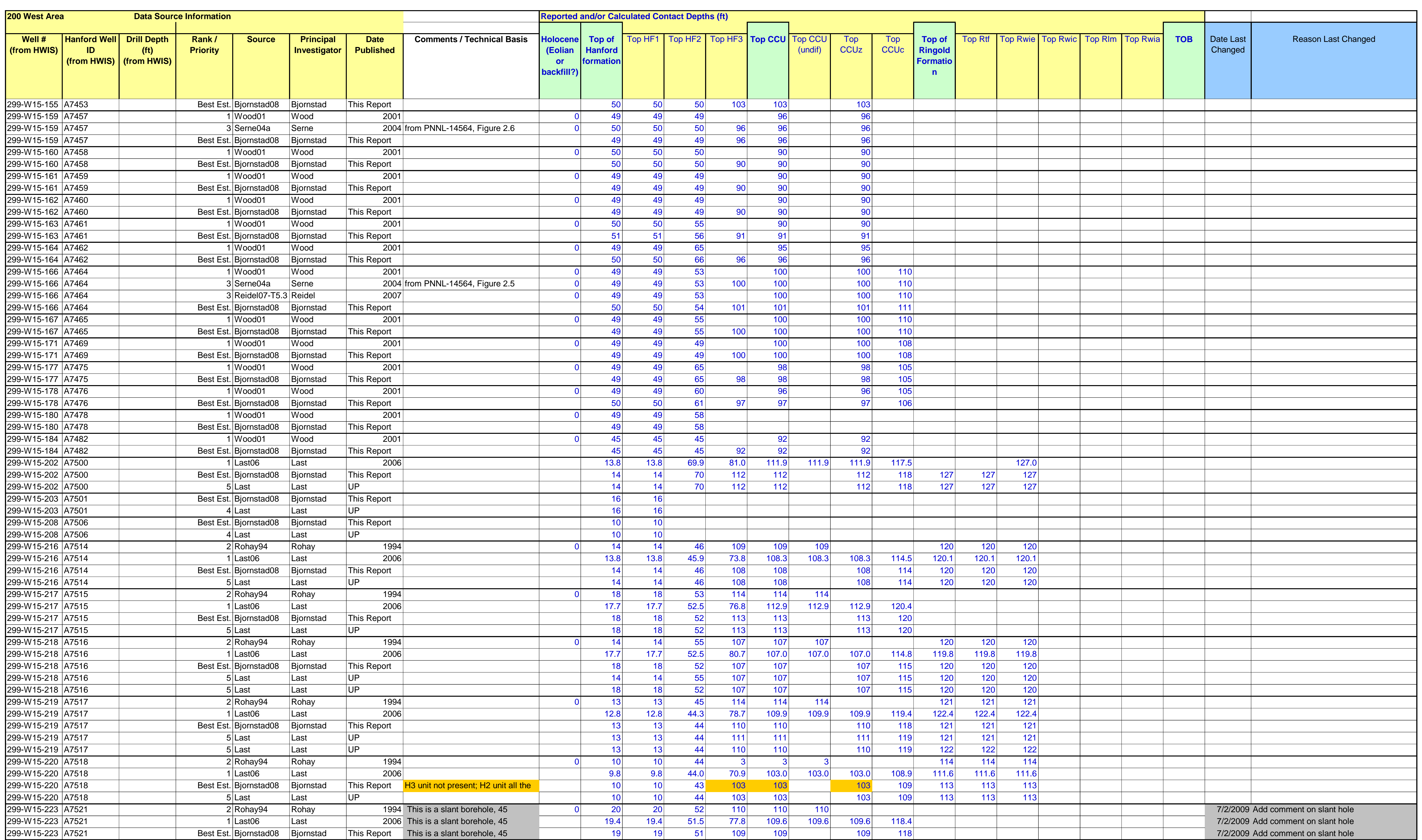




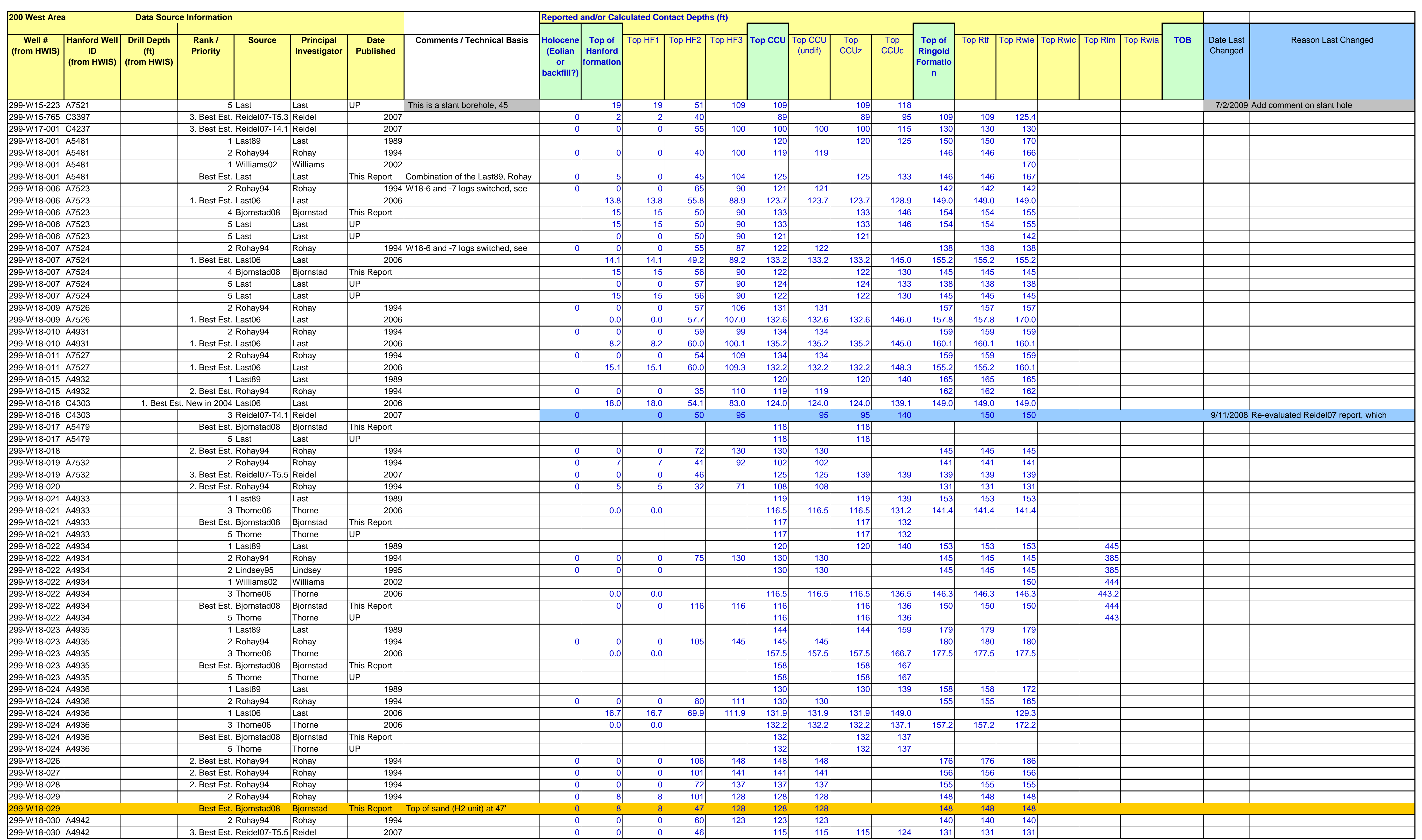




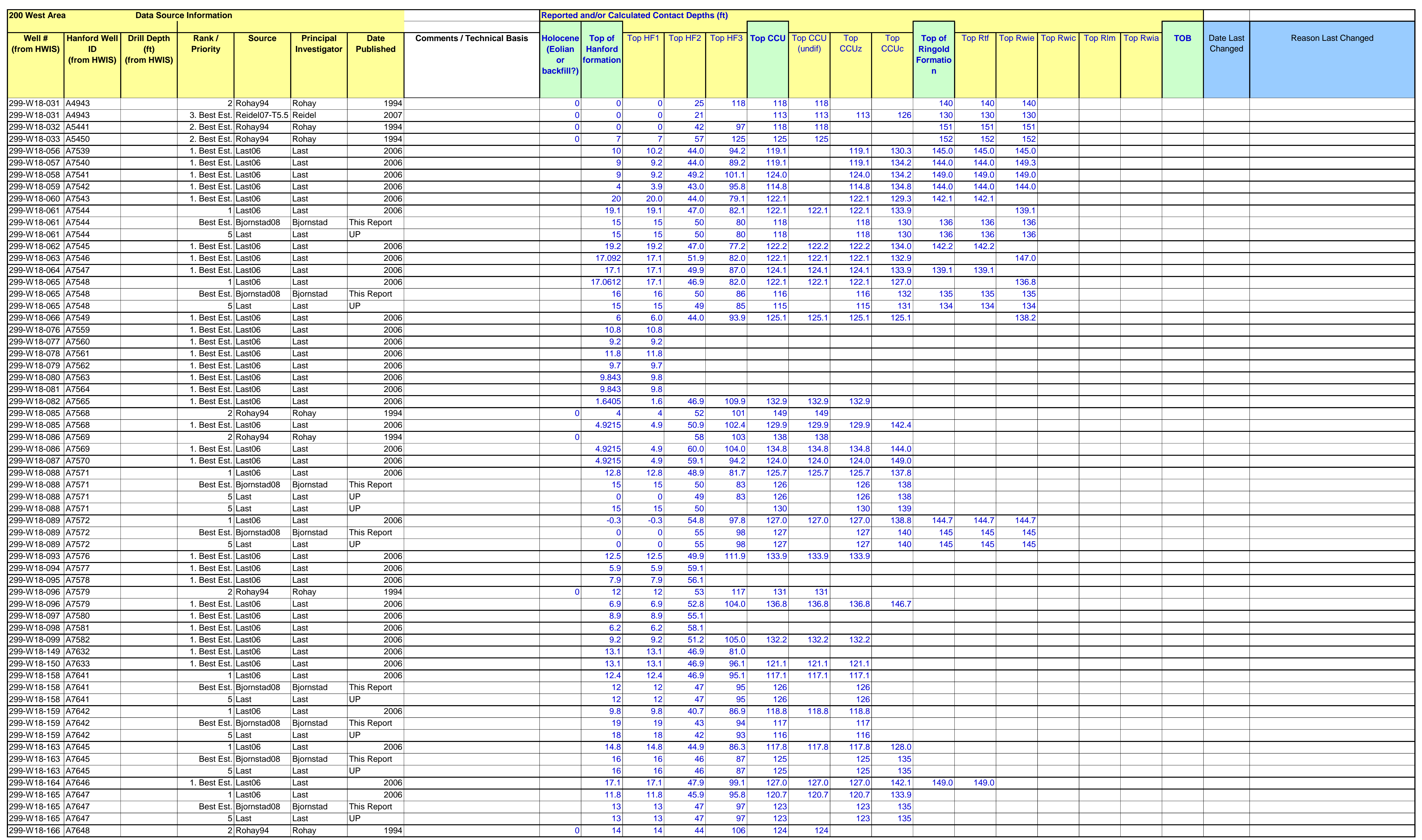




\begin{tabular}{|c|c|c|c|c|c|c|c|c|c|c|c|c|c|c|c|c|c|c|c|c|c|c|c|c|c|}
\hline 200 West Are & & $\begin{array}{ll}\text { Data Source } \\
1\end{array}$ & Information & & & & & Reported a & andlor Call & culated Cor & intact Depth & hs (tt) & & & & & & & & & & & & & \\
\hline $\begin{array}{c}\text { Well \# } \\
\text { (from HWIS) }\end{array}$ & $\begin{array}{l}\text { Hanford Well } \\
\text { ID } \\
\text { (from Hwis) }\end{array}$ & \begin{tabular}{|c|}
$\begin{array}{c}\text { Drill Depth } \\
\text { (ft) } \\
\text { (from HWIS) }\end{array}$ \\
(f)
\end{tabular} & 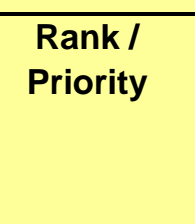 & 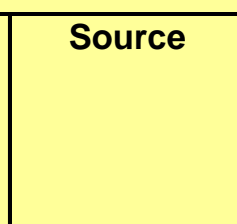 & \begin{tabular}{|c|c} 
Principal \\
Investigator
\end{tabular} & \begin{tabular}{|c|} 
Date \\
Published \\
\end{tabular} & Comments / Technical Basis & $\mid \begin{array}{c}\text { Holocenen } \\
\text { (Eolian } \\
\text { or } \\
\text { backill?) }\end{array}$ & $\begin{array}{c}\text { Top of } \\
\text { Hanford } \\
\text { formation }\end{array}$ & \begin{tabular}{|l|l|} 
Top HF1 \\
\end{tabular} & \begin{tabular}{|l|l|l|l|l|l|} 
Top HF2 \\
\end{tabular} & \begin{tabular}{|l|l|} 
Top HF3 \\
\end{tabular} & Top ccu & $\begin{array}{l}\text { Top cCu } \\
\text { (undif) }\end{array}$ & $\begin{array}{l}\text { Top } \\
\text { CCUz }\end{array}$ & $\begin{array}{l}\text { Top } \\
\text { CCUc }\end{array}$ & $\begin{array}{c}\text { Top of } \\
\text { Ringold } \\
\text { Formatio } \\
n \\
n\end{array} \mid$ & Top Rtt & \begin{tabular}{|l|l|l} 
Top Rwie & $\top$
\end{tabular} & Top Rwic & \begin{tabular}{|l|l|l} 
Top Rlm & $\top$ \\
\end{tabular} & Top Rwia & ТОВ & \begin{tabular}{|c|} 
Date Last \\
Changed
\end{tabular} & Reason Last Changed \\
\hline 299-W18-166 & A7648 & & 1. Best Est. & Last06 & Last & 2006 & & & 11.8 & 11.8 & 42.0 & 105.0 & $\mid 121.7$ & 121.7 & 121.7 & 134.8 & & & & & & & & & \\
\hline $\begin{array}{l}299-W 18-167 \\
299-W 18-67 \\
2\end{array}$ & & 134 & & Rohay94 & Rohay & 1994 & & & 17 & & 41 & $\begin{array}{ll}89 \\
890\end{array}$ & 118 & \begin{tabular}{c|c|}
118 \\
118
\end{tabular} & & & & & & & & & & & \\
\hline $\begin{array}{l}299-W 18-167 \\
299-W 167\end{array}$ & A7649 & 134 & 1. Best Est. & $\begin{array}{l}\text { Last06 } \\
\text { Bipronstado8 }\end{array}$ & $\begin{array}{l}\text { Last } \\
\text { Bipurstad }\end{array}$ & 2006 & & & $\begin{array}{c}9.8 \\
25\end{array}$ & $\begin{array}{l}9.8 \\
25 \\
25\end{array}$ & $\begin{aligned} 43.0 \\
54\end{aligned}$ & 88.9 & \begin{tabular}{|r|}
116.1 \\
120
\end{tabular} & 116.1 & $\frac{116.1}{1.1}$ & 132.9 & & & & & & & & $7 / 20 / 2009 \mathrm{c}$ & 3 Changed Best ESt, Bjornstad008 UP had \\
\hline $\begin{array}{l}2999-W 18-167 \\
299-W 18-167\end{array}$ & A7649 & $\begin{array}{l}134 \\
134\end{array}$ & & $\begin{array}{l}\text { Bjornstad08 } \\
\text { |Last }\end{array}$ & $\begin{array}{l}\text { Bjornstad } \\
\text { Last }\end{array}$ & $\begin{array}{l}\text { This Report } \\
\text { UP }\end{array}$ & & & $\begin{array}{l}25 \\
15 \\
\end{array}$ & $\begin{array}{l}255 \\
15\end{array}$ & $\begin{array}{r}54 \\
44\end{array}$ & $\begin{array}{r}100 \\
90\end{array}$ & \begin{tabular}{|l|}
128 \\
18 \\
\end{tabular} & & $\frac{128}{118}$ & $\begin{array}{l}144 \\
134\end{array}$ & & & & & & & & 7/20/2009 C & Changed Best ESt., Bjornstad08 UP had \\
\hline 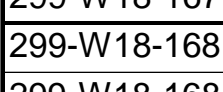 & & & & Rohay94 & Rohay & 1994 & & & 9 & 9 & 42 & 99 & $\begin{aligned} 119 \\
119\end{aligned}$ & 119 & & & & & & & & & & & \\
\hline 299-W18-168 & A7650 & & 1. Best Est. & Last06 & Last & 2006 & & & 10.8 & 10.8 & 42.3 & 99.7 . & 119.8 & 119.8 & 119.8 & & & & & & & & & & \\
\hline 299-W18-169 & A7651 & & 1. Best Est. & Lasto6 & Last & 2006 & & & 18.0 & 18.0 & 50.9 & 89.9 & 115.5 & 115.5 & $\frac{115.5}{}$ & & & & & & & & & & \\
\hline 299-W18-170 & & & 1. Best Est. & & Last & 2006 & & & 9.8 & $\begin{array}{l}9.8 \\
\end{array}$ & & & & & & & & & & & & & & & \\
\hline 299-W18-171 & A7653 & & 1. Best Est. & Lasto6 & Last & 2006 & & & 24.0 & 24.0 & 50.2 & 97.1 & 124.0 & 124.0 & 124.0 & & & & & & & & & & \\
\hline $\begin{array}{l}299-W 18-173 \\
2001910171 \\
\end{array}$ & A7655 & & 1. Best Est. & 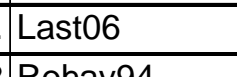 & Last & 2006 & & & $\frac{12.8}{211}$ & $\frac{12.8}{11}$ & 46.9 & & & & - & & & & & & & & & & \\
\hline $\begin{array}{l}299-W 18-174 \\
299-W 17-174\end{array}$ & $\begin{array}{l}A 7656 \\
\text { A7656 }\end{array}$ & & & Rohay94 & $\begin{array}{l}\text { Rohay } \\
\text { Last }\end{array}$ & $\begin{array}{l}1994 \\
2006\end{array}$ & & & $\begin{array}{r}14.1 \\
14.1\end{array}$ & $\begin{array}{r}14.1 \\
14.1\end{array}$ & $\begin{array}{r}47.2 \\
47.2\end{array}$ & $\begin{array}{r}855 \\
84.6 \\
\end{array}$ & $\begin{array}{r}120 \\
199.8\end{array}$ & \begin{tabular}{r|r}
120 \\
119.8
\end{tabular} & & & & & & & & & & & \\
\hline $\begin{array}{l}2999-W 18-174 \\
299-W 18-174 \\
27\end{array}$ & A75656 & & & $\begin{array}{l}\text { Latasto6 } \\
\text { Bjornstad08 }\end{array}$ & $\begin{array}{l}\text { Last } \\
\text { Bjornstad }\end{array}$ & $\begin{array}{ll}20006 \\
\text { This Report }\end{array}$ & & & 14.14 & 14.14 & $\begin{aligned} 47.2 \\
47\end{aligned}$ & \begin{tabular}{|r|}
84.6 \\
85 \\
\end{tabular} & 129.8 & 119.8 & $\begin{aligned} 119.8 \\
120\end{aligned}$ & 130.33 & & & & & & & & & \\
\hline $299-W 18-174$ & A7656 & & & Last & Last & UP & & & 14 & 14 & 47 & $\begin{array}{l}85 \\
85 \\
\end{array}$ & 120 & + & 120 & $\begin{array}{r}150 \\
130 \\
\end{array}$ & & & & & & & & & \\
\hline 299-W18-175 & \begin{tabular}{|l|l|}
$A 76657$ \\
17657
\end{tabular} & & & Rohay94 & Rohay & 1994 & & & 26 & 26 & 49 & 86 & $\begin{array}{l}126 \\
10104\end{array}$ & $\begin{array}{r}126 \\
1120\end{array}$ & & & & & & & & & & & \\
\hline$\frac{299-W 18-175}{299-W 18-246}$ & $\frac{\mid}{A 776726}$ & & 1. Best Est. & 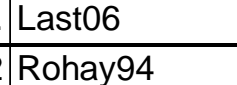 & $\frac{\text { Last }}{\text { Rohay }}$ & $\frac{2006}{1994}$ & & & $\begin{array}{l}9.8 \\
13 \\
13\end{array}$ & $\frac{9.8}{13}$ & $\begin{array}{l}46.9 \\
54\end{array}$ & 105 & $\frac{119.1}{1.14}$ & $\frac{119.1}{134}$ & 119.1 & & & & & & & & & & \\
\hline $\begin{array}{l}\frac{299-W 18-246}{299-W 18-246} \\
20\end{array}$ & $\begin{array}{l}\text { A7726 } \\
\text { A77726 }\end{array}$ & & 1. Best Est. & $\begin{array}{l}\text { Loshayy44 } \\
\text { Lasto6 }\end{array}$ & $\begin{array}{l}\text { Lohaya } \\
\text { Last }\end{array}$ & $\begin{array}{l}1994 \\
2006 \\
\end{array}$ & & & $\begin{array}{r}13 \\
12.5 \\
\end{array}$ & $\begin{array}{r}13 \\
12.5 \\
\end{array}$ & $\begin{array}{r}54 \\
54.1 \\
\end{array}$ & $\begin{array}{r}105.7 \\
104.7 \\
\end{array}$ & $\begin{array}{r}134 . \\
133.5 \\
\end{array}$ & $\begin{array}{r}1334 \\
133.5 \\
\end{array}$ & 133.5 & 145.7 & $\begin{array}{r}1577 \\
150.9 \\
\end{array}$ & $\begin{array}{r}157 \\
150.9 \\
\end{array}$ & $\begin{array}{r}147 \\
150.9 \\
\end{array}$ & & & & & & \\
\hline $299-W 18-247$ & A7581 & & & Rohay94 & Rohay & 1994 & & & 3 & 3 & 54 & \begin{tabular}{l|l}
115 \\
\end{tabular} & 131 & ${ }_{131}$ & & & 154 & 154 & 154 & & & & & & \\
\hline $299-W 18-247$ & A7581 & & 1. Best Est. & Last06 & Last & 2006 & & & 9.8 & 9.8 & 54.5 & 112.5 & 130.9 & 130.99 & 130.9 & 147.0 & & & & & & & & & \\
\hline 299-W18-248 & & & & Rohay94 & Rohay & 1994 & & & 12 & & 44 & & 126 | & & & & & & & & & & & & \\
\hline 299-W18-248 & A A7728 & & & Last06 & Last & 2006 & & & 11.5 & 11.5 & 43.6 & 86.6 & 125.7 & 125.7 & 125.7 & 138.5 & & & 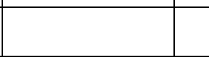 & & & & & & \\
\hline 299-W18-248 & A7728 & & Best Est. & Bjornstad08 & Bjornstad & This Report & & & $11 \mid$ & 11 & 43 & 87 & 126 & & 126 & 138 & & & & & & & & & \\
\hline$\frac{299-W 18-248}{209-W 18}$ & \begin{tabular}{|l|l|l}
$A 7728$ \\
$A 7728$
\end{tabular} & & & Last & $\begin{array}{l}\text { Last } \\
\end{array}$ & UP & & & 12 & 12 & 44 & \begin{tabular}{l|l|l|}
86 \\
87
\end{tabular} & $\begin{array}{l}126 \\
\end{array}$ & - & 126 & & & & & & & & & & \\
\hline$\frac{\mid 299-W 18-48}{299-W 18-249}$ & \begin{tabular}{|l|l} 
A77728 \\
A
\end{tabular} & & $\frac{5}{2}$ & \begin{tabular}{|l|l|l|l|} 
Lost \\
Rohayy94
\end{tabular} & $\frac{\text { Last }}{\text { Rohay }}$ & & & & $\frac{10}{6}$ & $\frac{10}{6}$ & $\begin{array}{l}40 \\
58\end{array}$ & $\begin{array}{r}\quad 87 \\
104\end{array}$ & $\mid$\begin{tabular}{|c|}
$\mid 126$ \\
131
\end{tabular} & & 126 & 138 & & & & & & & & & \\
\hline$\frac{299-W 18-249}{299-W 18-249}$ & $\begin{array}{l}\text { A7729 } \\
\text { A77729 }\end{array}$ & & 1. Best Est. & $\begin{array}{l}\text { Roshayy4 } \\
\text { Lasto6 }\end{array}$ & $\begin{array}{l}\text { Lohasay } \\
\text { Last }\end{array}$ & $\begin{array}{l}1994 \\
2006 \\
\end{array}$ & & & $\begin{array}{r}6 \\
5.9 \\
\end{array}$ & $\begin{array}{r}6 \\
5.9 \\
\end{array}$ & $\begin{array}{r}58 \\
58.1 \\
\end{array}$ & $\begin{array}{r}1044 \\
102.4 \\
\end{array}$ & $\begin{array}{r}\frac{131}{130.9} \\
\end{array}$ & $\begin{array}{r}1311 \\
130.9 \\
\end{array}$ & 130.9 & 143.1 & 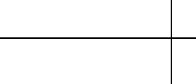 & & & & & & & & \\
\hline 299-W18-252 & A7732 & & & Rohayy4 & Rohay & 1994 & & & 1 & 1 & 51 & 101 & \begin{tabular}{l|l}
125 \\
\end{tabular} & 125 & 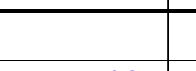 & & $\begin{array}{ll}140 \\
\end{array}$ & 140 & $\begin{array}{l}140 \\
\end{array}$ & & & & & & \\
\hline 299-W18-252 & A7732 & & Best Est. & Bjornstad08 & $\begin{array}{l}\text { Bjormstad } \\
\text { ats }\end{array}$ & This Report & & & 12 & 12 . & 51 & 101 & 125 & & 125 & 138 & 140 & 140 & 140 & & & & & & \\
\hline $\begin{array}{l}\frac{299-W 18-252}{299-W 18-252} \\
2\end{array}$ & \begin{tabular}{|l} 
A77772 \\
A7732
\end{tabular} & & & $\begin{array}{l}\text { Latast } \\
\text { Last }\end{array}$ & $\begin{array}{l}\text { Last } \\
\text { Last }\end{array}$ & $\begin{array}{l}\text { UP } \\
\text { UP }\end{array}$ & & & $\begin{array}{r}1 \\
12\end{array}$ & $\begin{array}{r}1 \\
12\end{array}$ & $\begin{array}{l}51 \\
51\end{array}$ & $\begin{array}{l}101 \\
101\end{array}$ & $\begin{array}{l}125 \\
125\end{array}$ & & $\begin{array}{l}125 \\
125\end{array}$ & 138 & & 140 & $\begin{array}{l}140 \\
140\end{array}$ & & & & & & \\
\hline $299-$ W W18-253 & C4965 & & 2006 & Last & Last & & & & 14 & $1<4$ & 31 & 101 & 165 & & $12 \%$ & 150 & 140 & 140 & 140 & & & & & & \\
\hline 299-W19-001 & A4944 & & 1 & \begin{tabular}{|l|l|} 
Last89 \\
\end{tabular} & $\begin{array}{ll}\text { Last } \\
\end{array}$ & 1989 & & & & - & - & & \begin{tabular}{l|l}
125 \\
\end{tabular} & & 125 & 150 & 160 & 160 & $\begin{array}{ll}160 \\
\end{array}$ & & & & & & \\
\hline 299-W19-001 & A4944 & & 3. Best Est. & Reidel07-T5.5 & Reidel & 2007 & & & 0 & 0 & 42 & & 124 & 124 & 124 & 141 & 147 & 147 & 147 & & & & & & \\
\hline 299-W19-002 & $\begin{array}{l}\text { A49448 } \\
\text { A77723 }\end{array}$ & & 1, Best Est. & Last89 & $\begin{array}{ll}\text { Last } \\
\end{array}$ & 19089 & 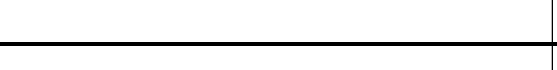 & & 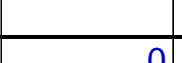 & & 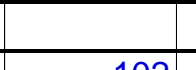 & & 158 & & 158 & 185 & 203 & 2033 & 240 & & & & & & \\
\hline 299-W19-003 & A77733 & & 3. Best Est. & Reidel07-T5.5 & Reidel & 2007 & & & 0 & 0 & 1022 & & 178 & $178 \mid$ & 193 & 193 & 193] & 1993] & 193[ & & & & & & \\
\hline |299-W199-004 & A4958 & & & :Lindsey95 & Lindsey & 1995 & & & 5 & 5 & - & & 167 & 167 & 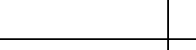 & -1 & 243 & 243 & 262 & & 503 & 522 & rats & & \\
\hline 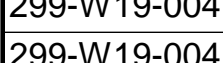 & 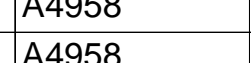 & & & \begin{tabular}{|l|} 
Williams022 \\
Ihomene6
\end{tabular} & $\begin{array}{l}\text { Whimams } \\
\text { Thome }\end{array}$ & 2006 & & & & 00 & & & & & & & & & 262 & & 年 1430 & 告65 & $\frac{545}{529}$ & & \\
\hline $\mid \begin{array}{l}2099-\mathrm{W} 190.004 \\
2904\end{array}$ & A49508 & & & $\begin{array}{l}\text { nerorneub } \\
\text { Reidel07-T.5 }\end{array}$ & SRemet & 2007 & & & $\begin{array}{r}0.0 \\
5\end{array}$ & 5 & & & 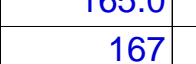 & 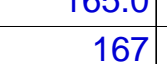 & 243 & 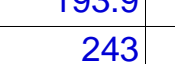 & 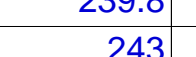 & 年 & 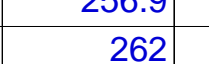 & & 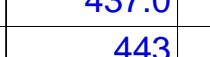 & (520.0 & 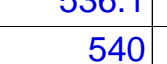 & & \\
\hline 299-W19-004 & A4958 & & Best Est. & Bjornstad08 & Bjornstad & This Report & & & 6 & 6 & & & 166 & & 166 & 195 & 244 & 244 & 263 & & 444 & 466 & 546 & & \\
\hline $299-W 19-$ & A4958 & & & Thorne & Thorne & & & & & & & & 165 & & 165 & 194 & & & & & 437 & 447] & 536 & & \\
\hline $299-W 19-008$ & A7736 & & & Last89 & $\begin{array}{l}\text { Last } \\
\text { Inindeov }\end{array}$ & $\begin{array}{l}1989 \\
1095\end{array}$ & & & & 0 & -1 & & 175 ; $>3$ & 1755 & $\mathrm{C}_{\mathrm{C}}$ & 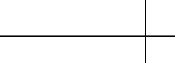 & 210 & 210 & 210 & & 132 & $\sqrt{165}$ & 560 & & \\
\hline \begin{tabular}{|l|l|}
$299-\mathrm{W}-\mathrm{W} 19-008$ \\
\end{tabular} & A7736 & & & 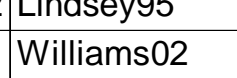 & $\begin{array}{l}\text { Whasey } \\
\text { Williams }\end{array}$ & 2002 & & & 0 & 0 & 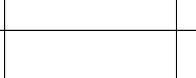 & & $1 / 5$ & $1 / 5$ & & & 210 & 210 & $\begin{array}{l}210 \\
186\end{array}$ & & $\begin{array}{l}433 \\
433\end{array}$ & 465 & 570 & & \\
\hline $299-W 19-008$ & A7736 & & & Reidelo7-T5.5 & Reidel & 2007 & & & 0 & +5 & & & 175 & 175 & 210 & 210 & 210 & 210 & 210 & & 433 & 502 & 560 & & \\
\hline & A7736 & & Best Est. & Bjornstad08 & & This Report & & & 1 & 1 & & & $\begin{array}{l}176 \\
\end{array}$ & 176 & & $=$ & 211 & 211 & 211 & & 434 & 4911 & 571 & & \\
\hline 299-W19-010 & A7738 & & 2 & Bjornstad84 & Bjornstad & 1984 & & & 0 & 0 & & & 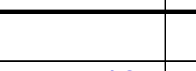 & $\underline{T}$ & & 159 & 168 & 168 & 168 & & 458 & 485 & 556 & & \\
\hline 299-W19-010 & A7738 & & & Last89 & Last & 1989 & & & & 1 & 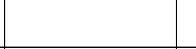 & & 135[ & & 135 & 160 & 170 & 170 & $170 \mid$ & & 458 & 485 & 556 & & \\
\hline $\begin{array}{ll}299-1 \\
2009\end{array}$ & $\begin{array}{l}\text { A7738 } \\
\text { A7720 }\end{array}$ & & & & $\begin{array}{l}\text { Lind } \\
\text { Whiid }\end{array}$ & 1995 & & & 0 & 0 & & & 140 & 140 & & & 171 & $171 \mid$ & 171 & & $\begin{array}{l}459 \\
460\end{array}$ & $\begin{array}{ll}4855 \\
4855\end{array}$ & 555 & & \\
\hline $299-W$ & $\mid A 77788$ & & & Wivilie & $\begin{array}{l}\text { Wili } \\
\text { with }\end{array}$ & 2002 & & & & & & & & & & & & & & & 告60 & 485 & & & \\
\hline$\frac{299-W 19-10-10}{299-W 10-010}$ & $\mid$ & & & Thorne06 & $\begin{array}{l}\text { Thore } \\
\text { Theiral }\end{array}$ & 2006 & & & 0.0 & 0.0 & 63 & & 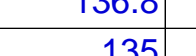 & 年30.0 & 136.8 & 156.8 & 1676. & 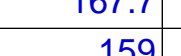 & 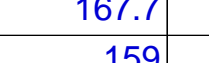 & & 4555.t & (882.0 & (51.60 & & \\
\hline$\frac{299-w}{29-w}$ & A7738 & & Best Est. & Biorstados & $\begin{array}{l}\text { Readiel } \\
\text { Bijornstad }\end{array}$ & This Reoport & Incorporated HF2 contact from & & of & 0 & 63 & & 135 & 135 & 135 & 159 & 168 & 168 & 168 & & 458 & 485 & 556 & & \\
\hline$\angle 99-w_{w}>2>0$ & A7738 & & & Thorne & Thorne & UP & & & & & & & 137 & & 137 & 157 & & & & & 456 & 482 & 552 & & \\
\hline > & A4945 & & & Rohay94 & Rohay & 1994 & & & & & & & & & {[} & - & $\frac{160 \mid}{160}$ & $\frac{160}{160}$ & 160 & & 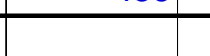 & t & & & \\
\hline 2099-W19-r & A4945 & & Best Est. & Horneros & Hormer & This Report F & Revaluated Dirl Log due to contact & & 4 & 4 & 50 & 120 & 120 & 120 & 120 & 140 & 155 & $155^{\circ}$ & 155 & & & & & & \\
\hline 2099-W19- & A77740 & & 3. $\mathrm{B}$ & Reidel07-T5.5 & Rei & 2007 & & 0 & 이 & o & $\frac{110}{110}$ & & $170 \mid$ & 170| & 180 & 180 & 1800 & 180] & $180 \mid$ & & & & & & \\
\hline 209-W19 & A499 & & 3. Best Est. & Reidelo7-T5.5 & Rei & 2007 & & & & 0 & 1122 & & 162 & 162 & 172 & 172 & 1722 & 1722 & 1722 & & & & & & \\
\hline 89-W/19-016 & A4947 & & 3. Best Est. & 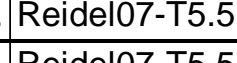 & 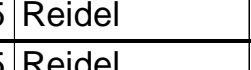 & 2007 & & & 0 & $\frac{0}{0}$ & $\frac{105}{91}$ & & $\frac{147 \mid}{140}$ & $\frac{147}{140}$ & $\frac{147}{167}$ & $\frac{163}{167}$ & 166 & 166 & 176 & & & & & & \\
\hline 2299-W19-016 & |A7741 & & 3. Best Est: & Reiddel07-T5.5 & |Reidel & & & & & & & & & & & & & & & & & & & & \\
\hline
\end{tabular}




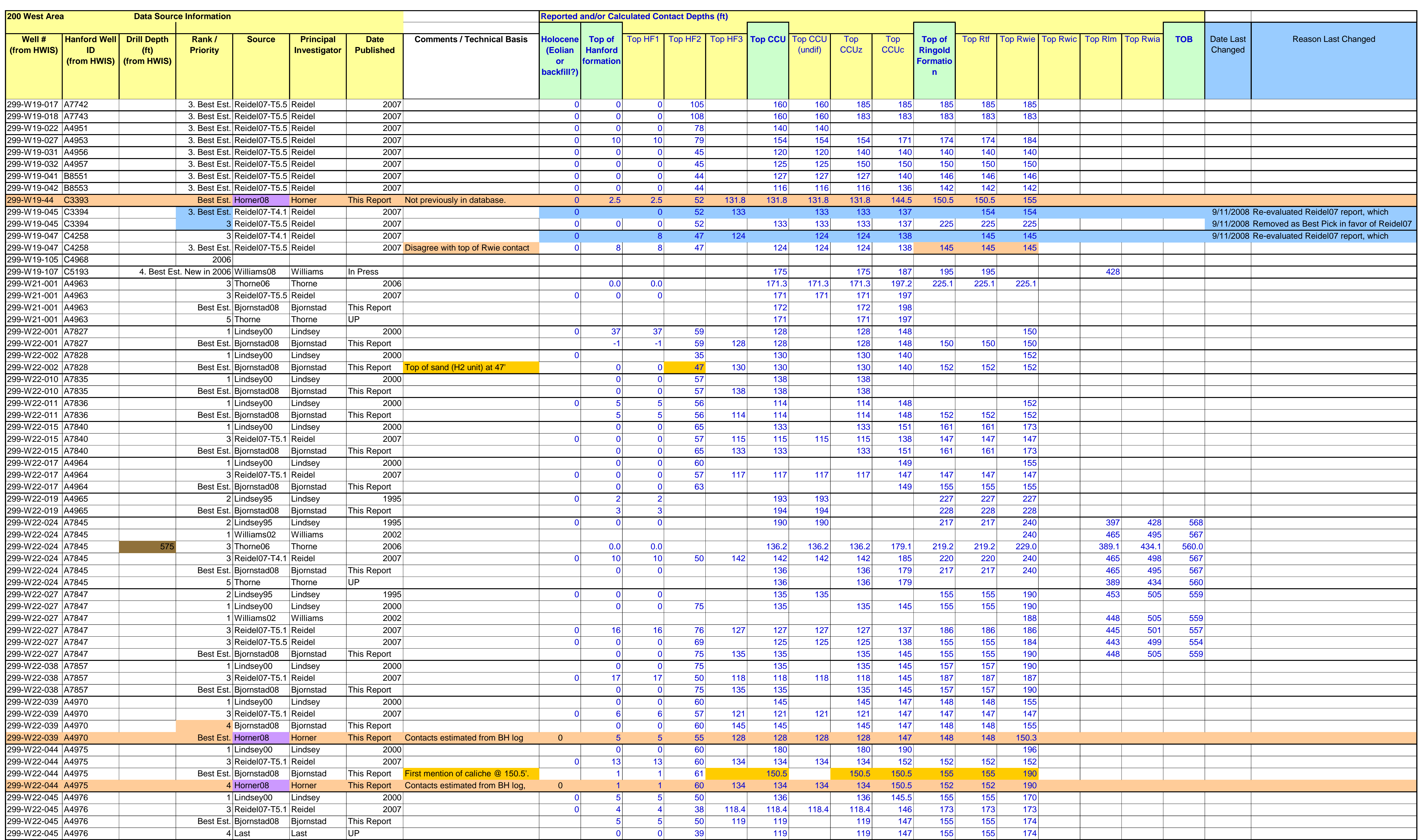




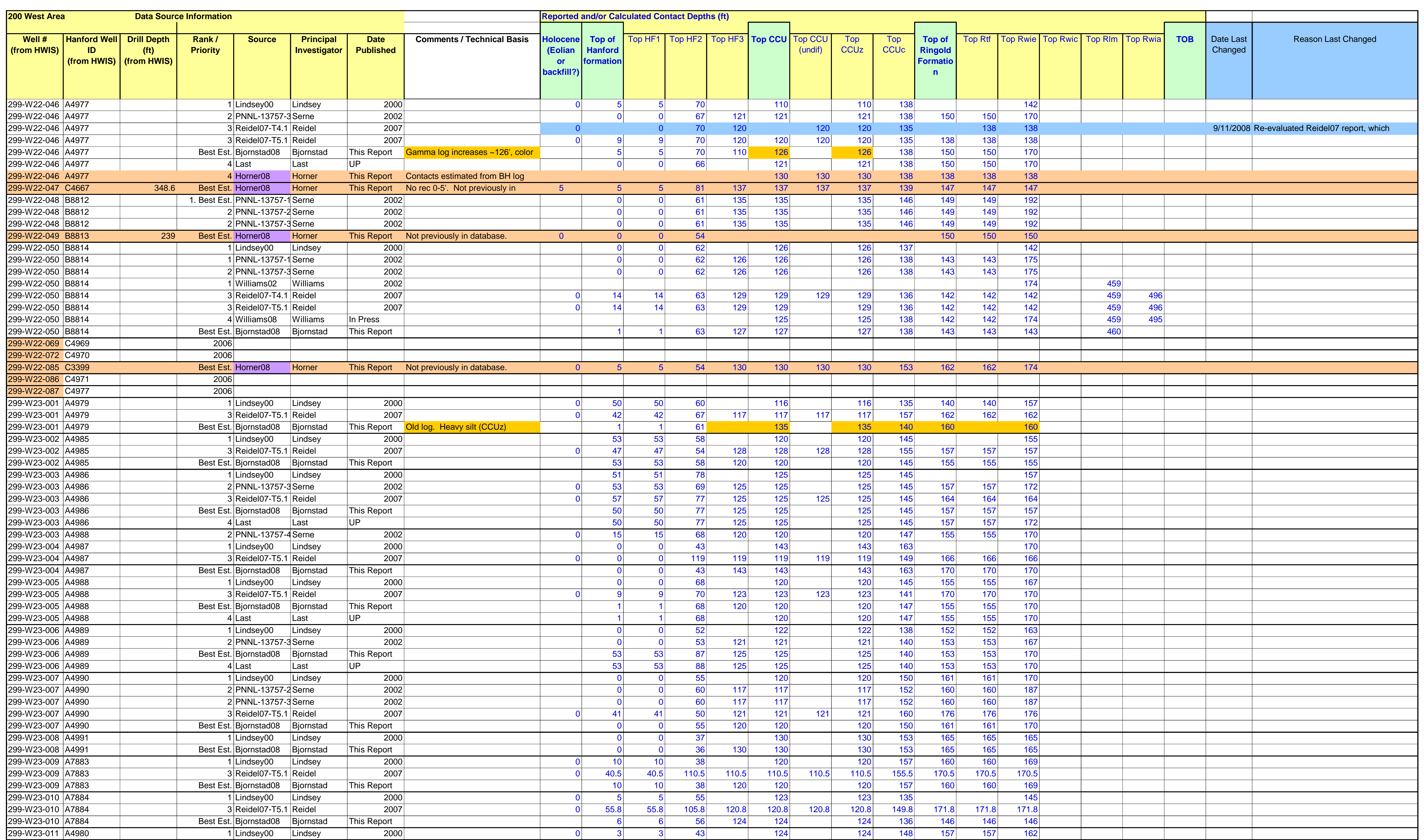




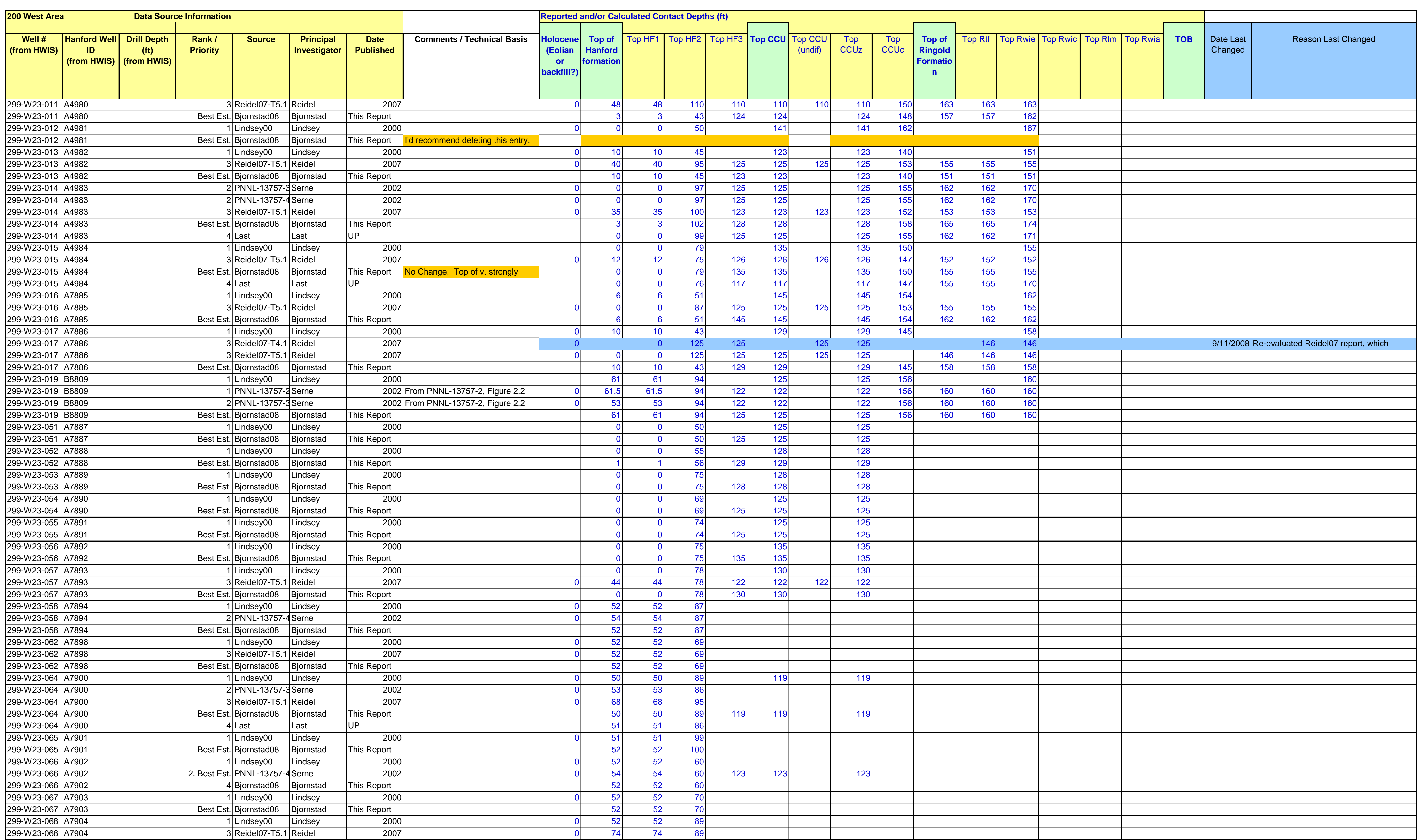




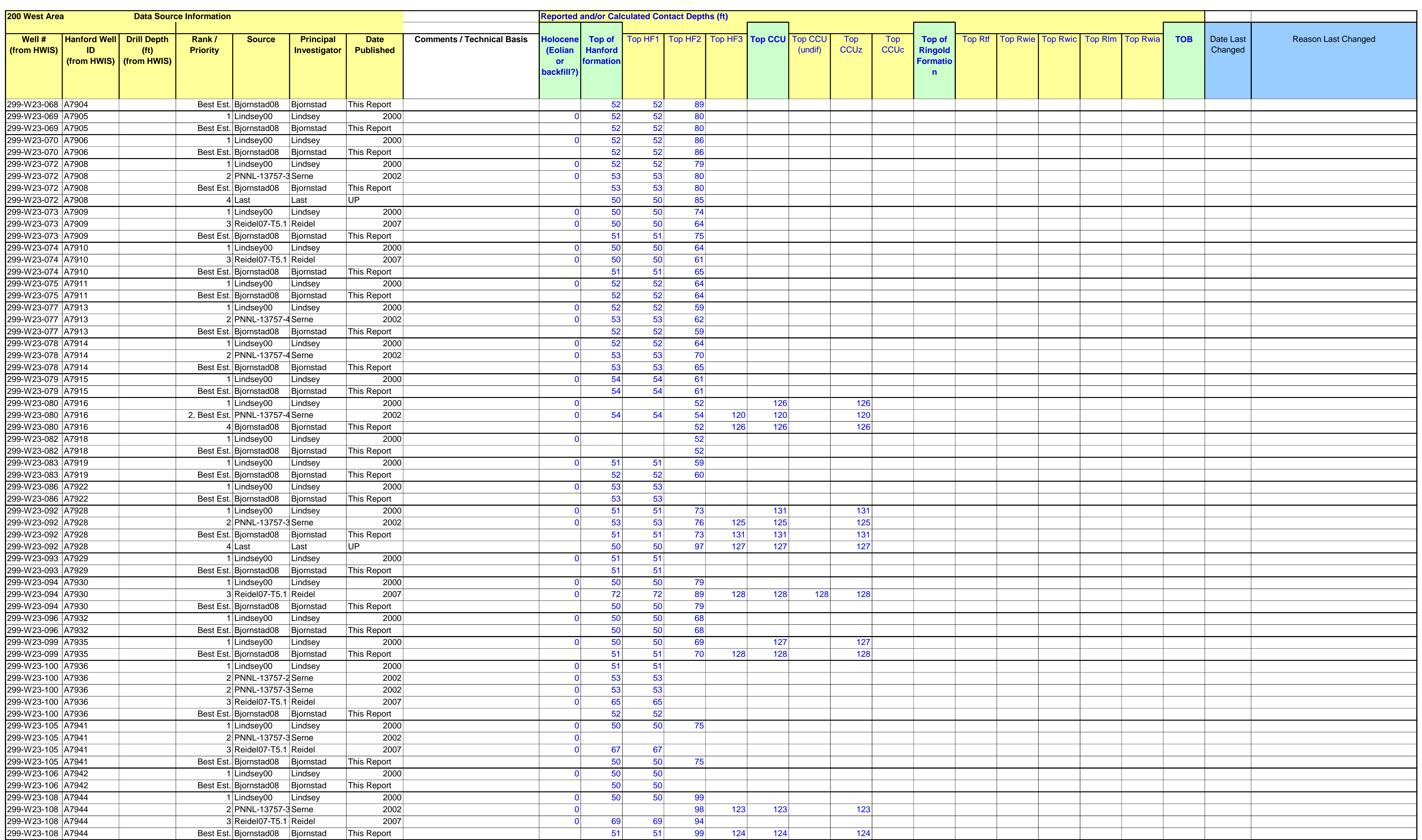




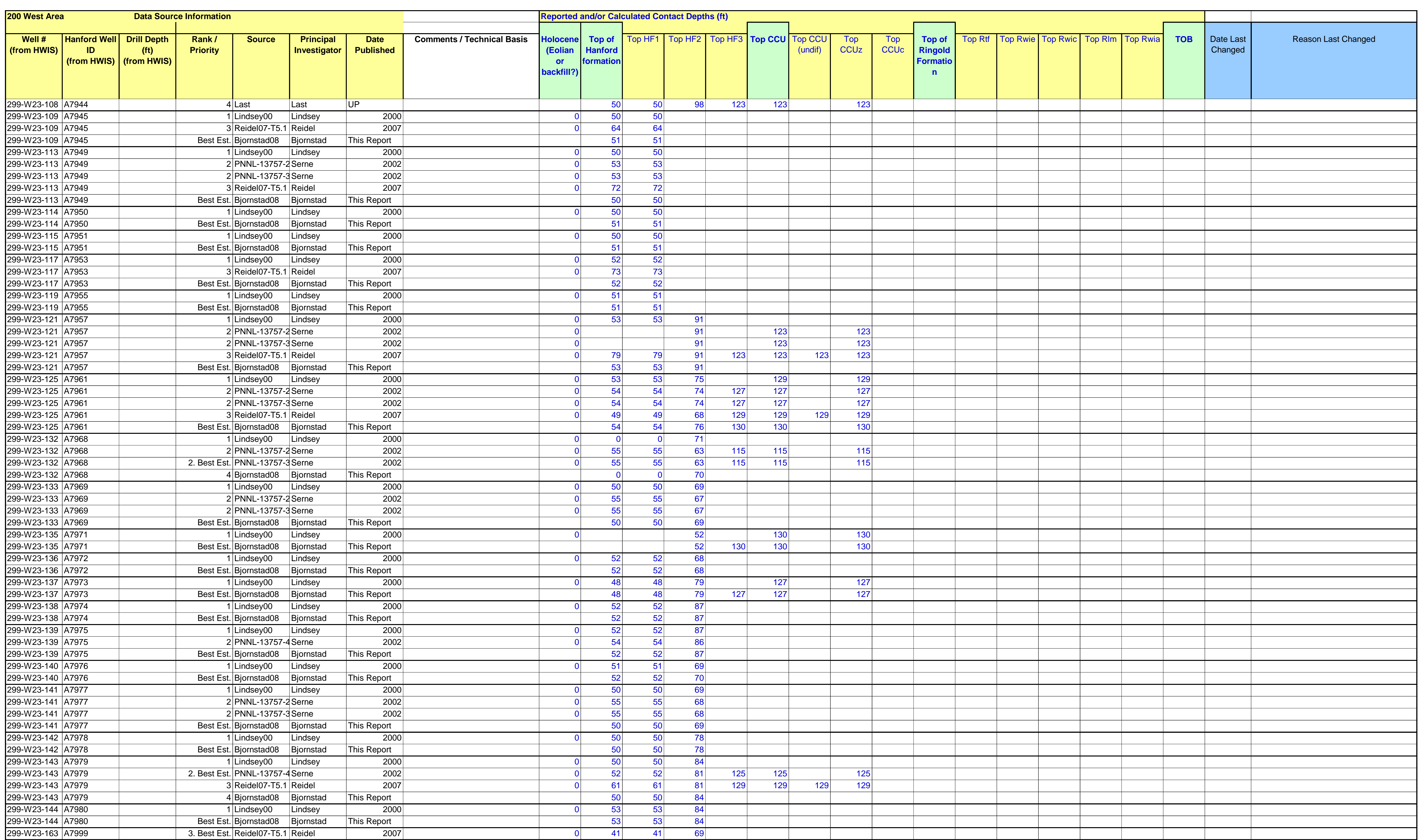




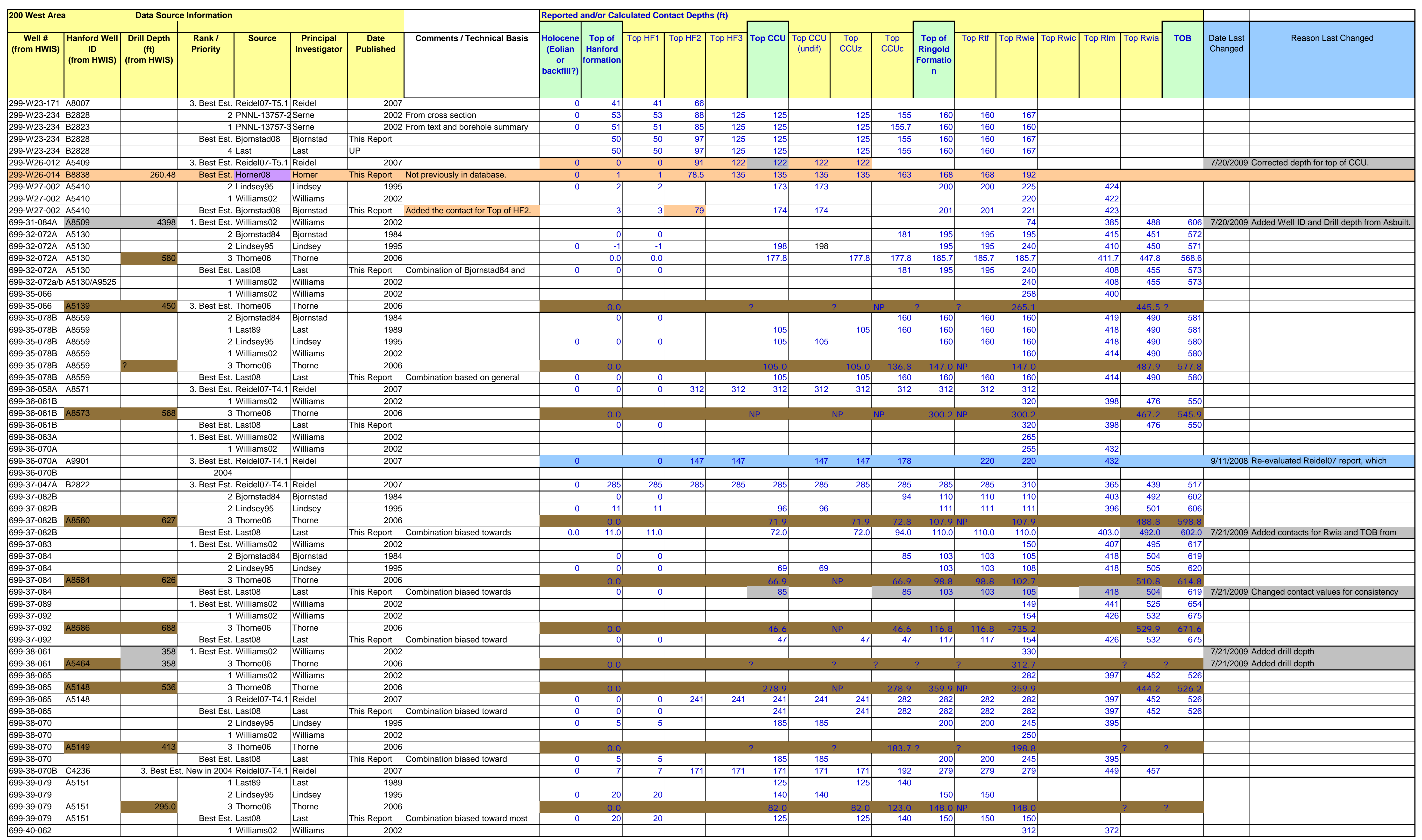




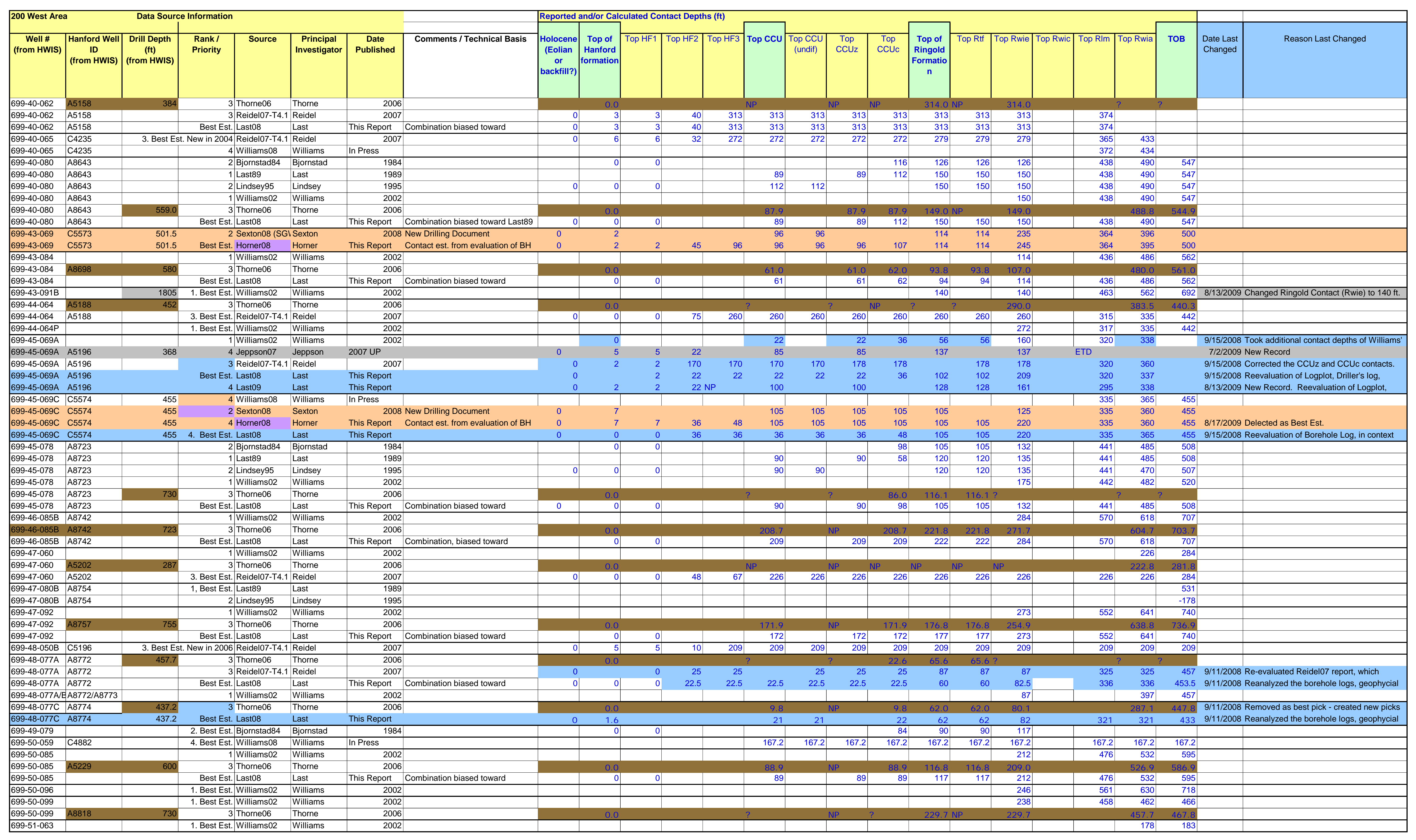




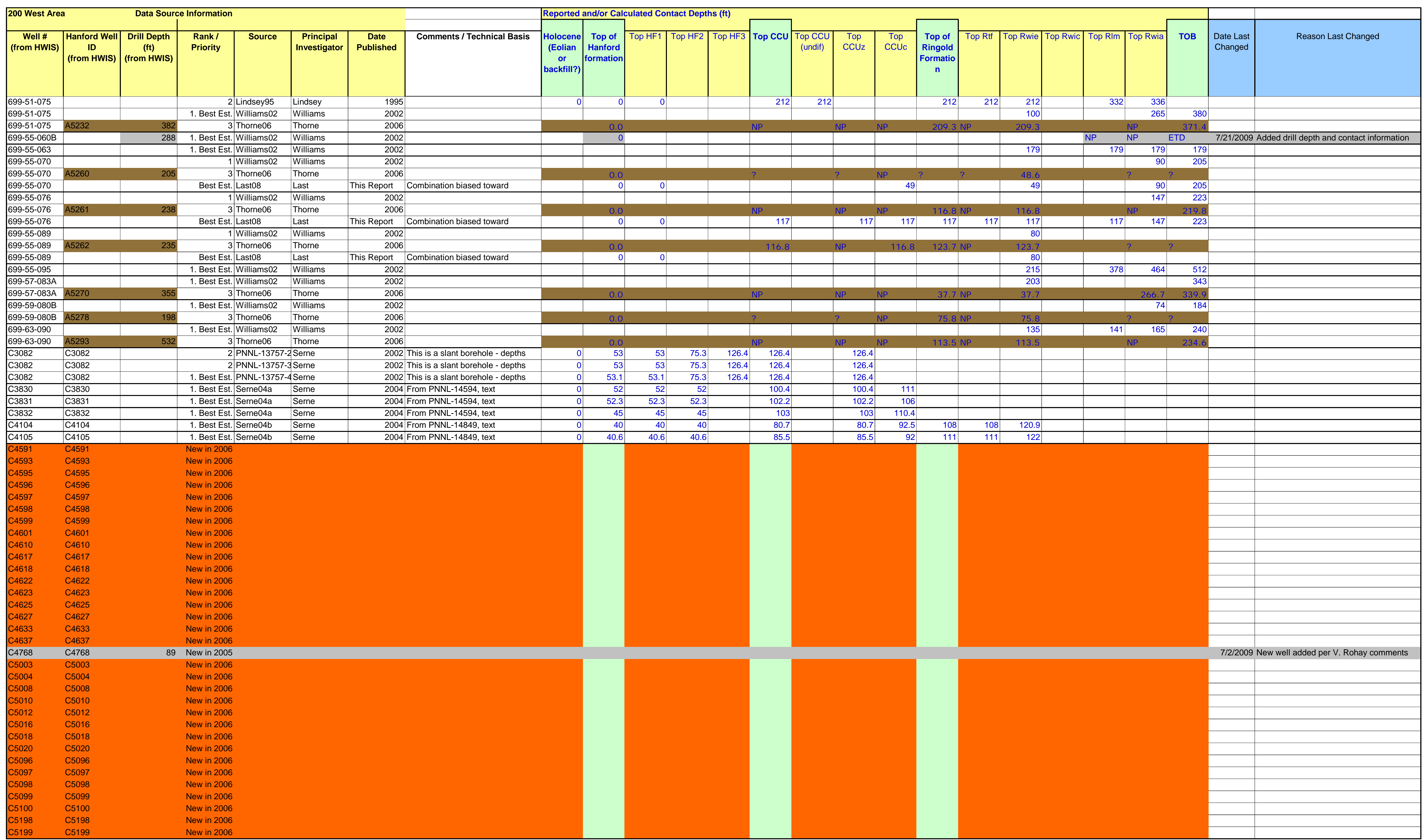




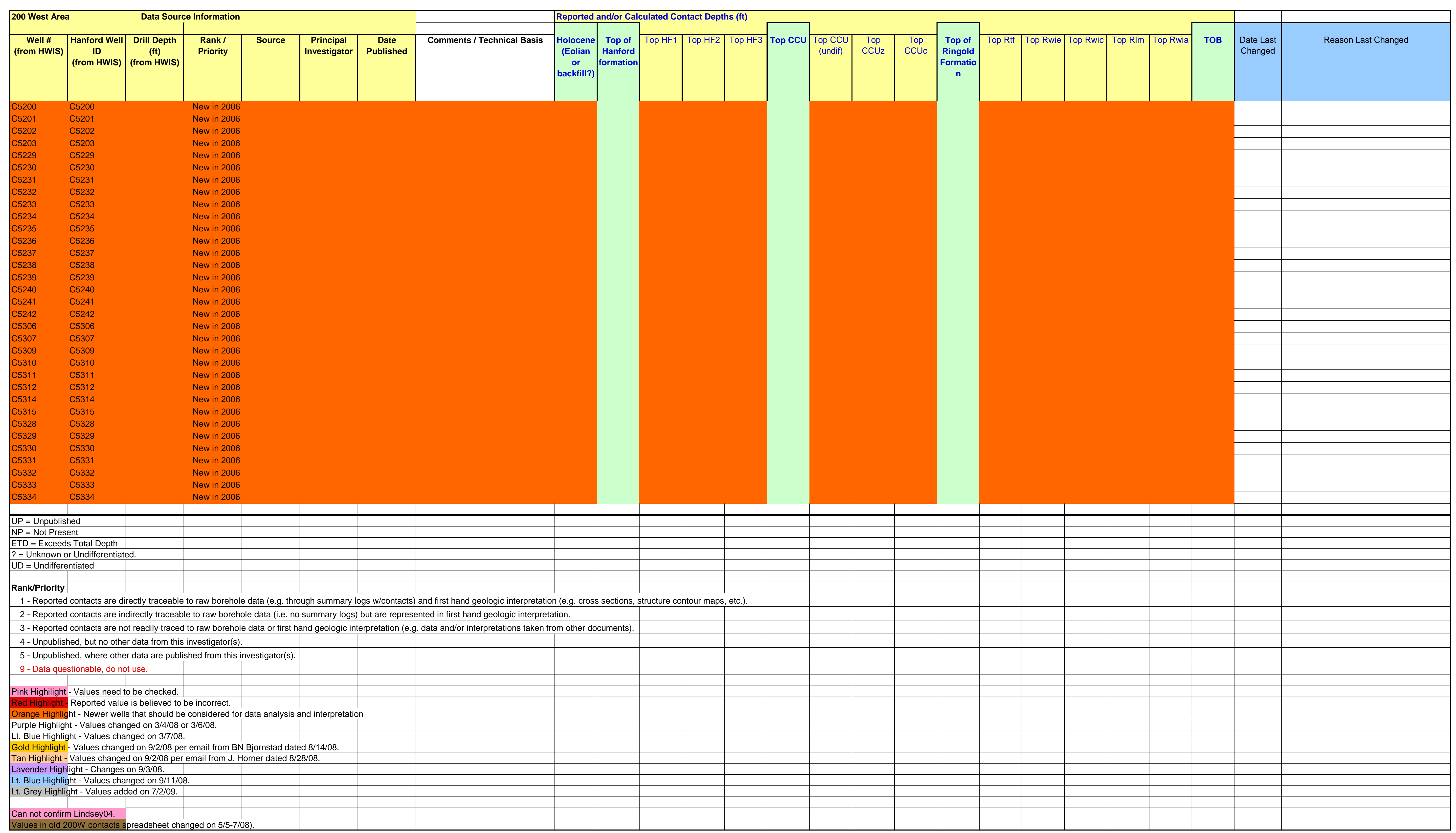




\section{Appendix B}

Best-Estimate Ground-Surface Elevations for Wells and Boreholes in and Around the 200 West Area 


\section{Appendix B}

\section{Best-Estimate Ground-Surface Elevations for Wells and Boreholes in and Around the 200 West Area}

Best-estimate ground-surface elevations ${ }^{1}$, in meters (presumably at the time of drilling, and presumably relative to NAVD88), were calculated using the following set of logic rules:

1. If the HWIS contained an elevation (vertical survey) value described as surveyed from ground surface (brass survey marker) or ground surface (assumed), that value was used as the ground-surface elevation in meters.

2. If the HWIS did not contain vertical survey value as describe above but did contain a DISC_Z value, that value was used as a proxy for the ground-surface elevation. When compared, those values identified as the elevation of the brass survey marker and the DISC_Z values were identical when rounded to the nearest $0.01 \mathrm{~m}$.

3. If neither 1 nor 2 above were applicable, then the ground-surface elevation was calculated from the HWIS vertical survey value described as having been surveyed from the top of one of the casings or the top of the pump plate using the HWIS stickup value (converted from feet to meters using a conversion factor of $3.28084 \mathrm{ft} / \mathrm{m}$ ). If multiple stickup values were found, then the stickup value associated with the earliest documented inspection date was used as most representative to yield the ground-surface elevation at the time of drilling.

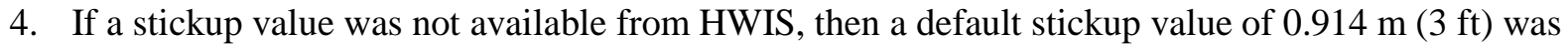
used to calculate the ground-surface elevation.

5. If there was no vertical survey value for the top of casing, then the ground-surface elevation was left blank or estimated using professional judgment based on the ground-surface elevations for nearby wells and the surrounding topography.

6. Where the ground-surface elevation was known to have been altered after the borehole was drilled (e.g., soil cover added at BC cribs), and/or the estimated ground-surface elevation base on the HWID data is suspected as not be representative of the time of drilling, then historical ground-surface elevation data from old Hanford wells documents (e.g., McGhan $1989^{2}$ ) was be used to estimate the ground surface at the time of drilling.

HWIS vertical survey data are reported in meters using the NAVD88 datum. However, stickup values and other older elevation values (e.g., Hanford Wells [McGhan 1989]) often are in feet using the NGVD29. Thus, these values were first converted to meters using the NAVD88 prior to calculating the best-estimate ground-surface elevation at the time of drilling. Current and historical stickup values also are documented in feet, so these also were converted to meters for subsequent calculations.

\footnotetext{
${ }^{1}$ The database is included in the Excel file, Best Est. GS Elev_2008-09-07.xls, in this Appendix B subfolder.

${ }^{2}$ McGhan VL. 1989. Hanford Wells. PNL-6907, Pacific Northwest Laboratory, Richland, Washington.
} 


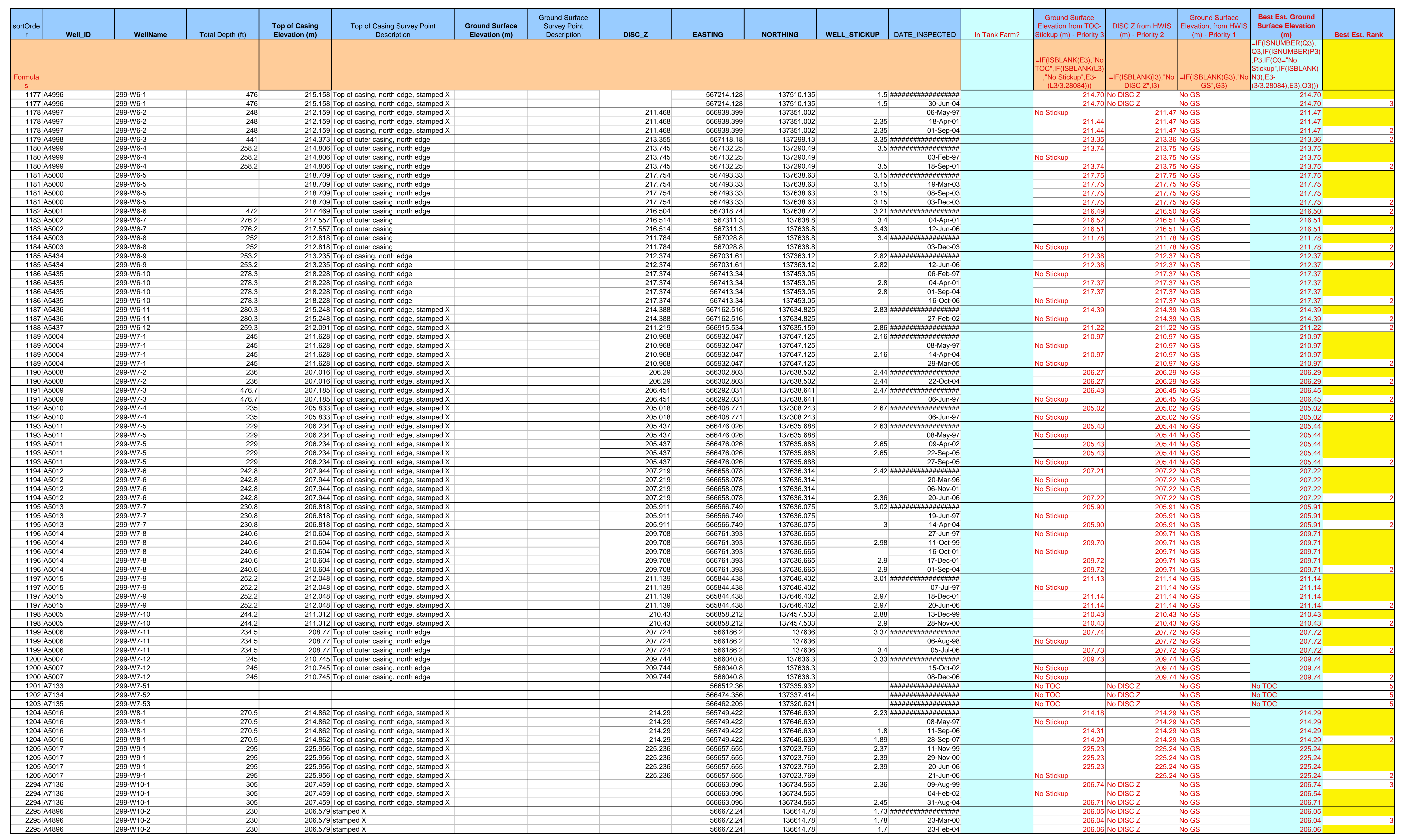




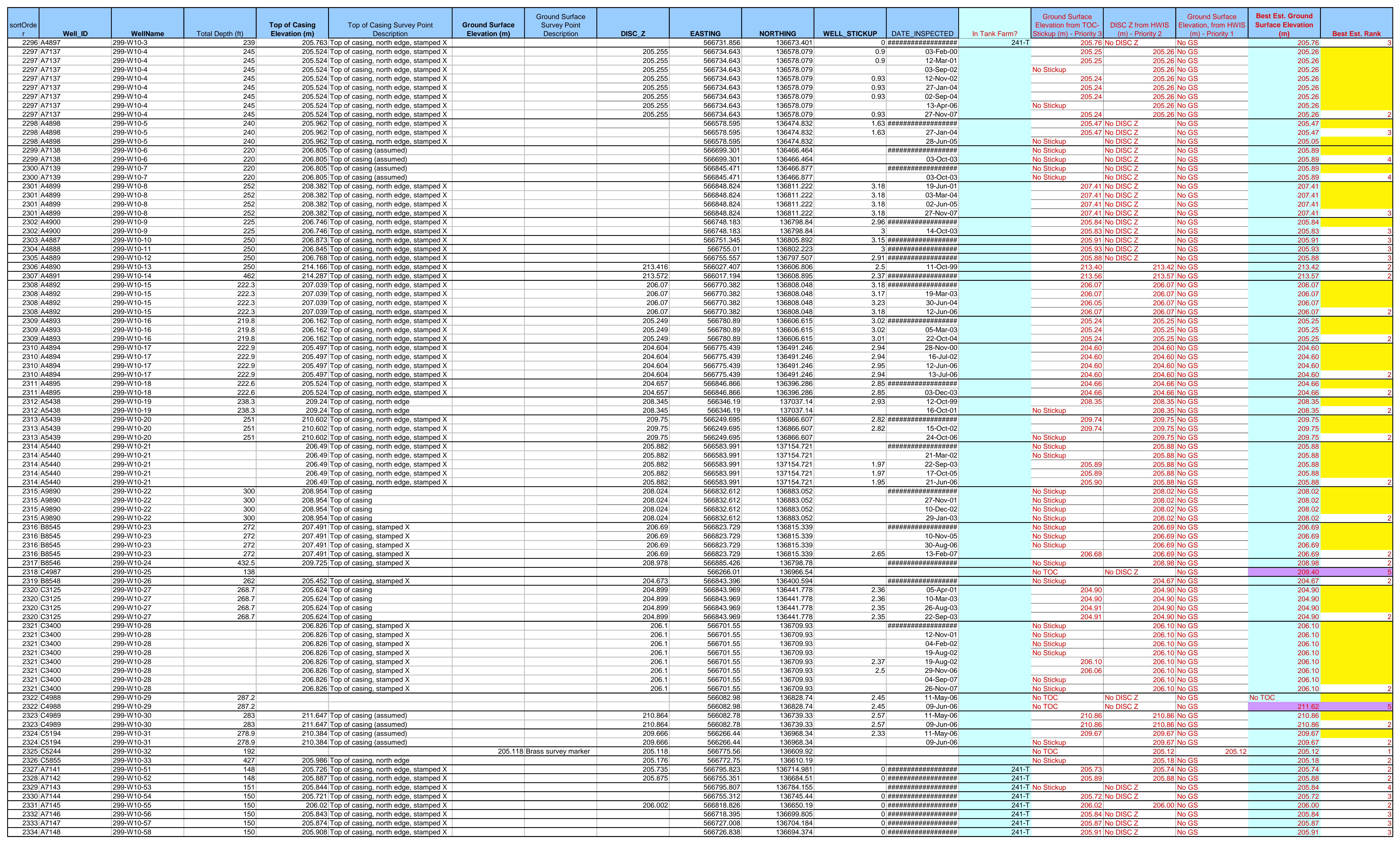




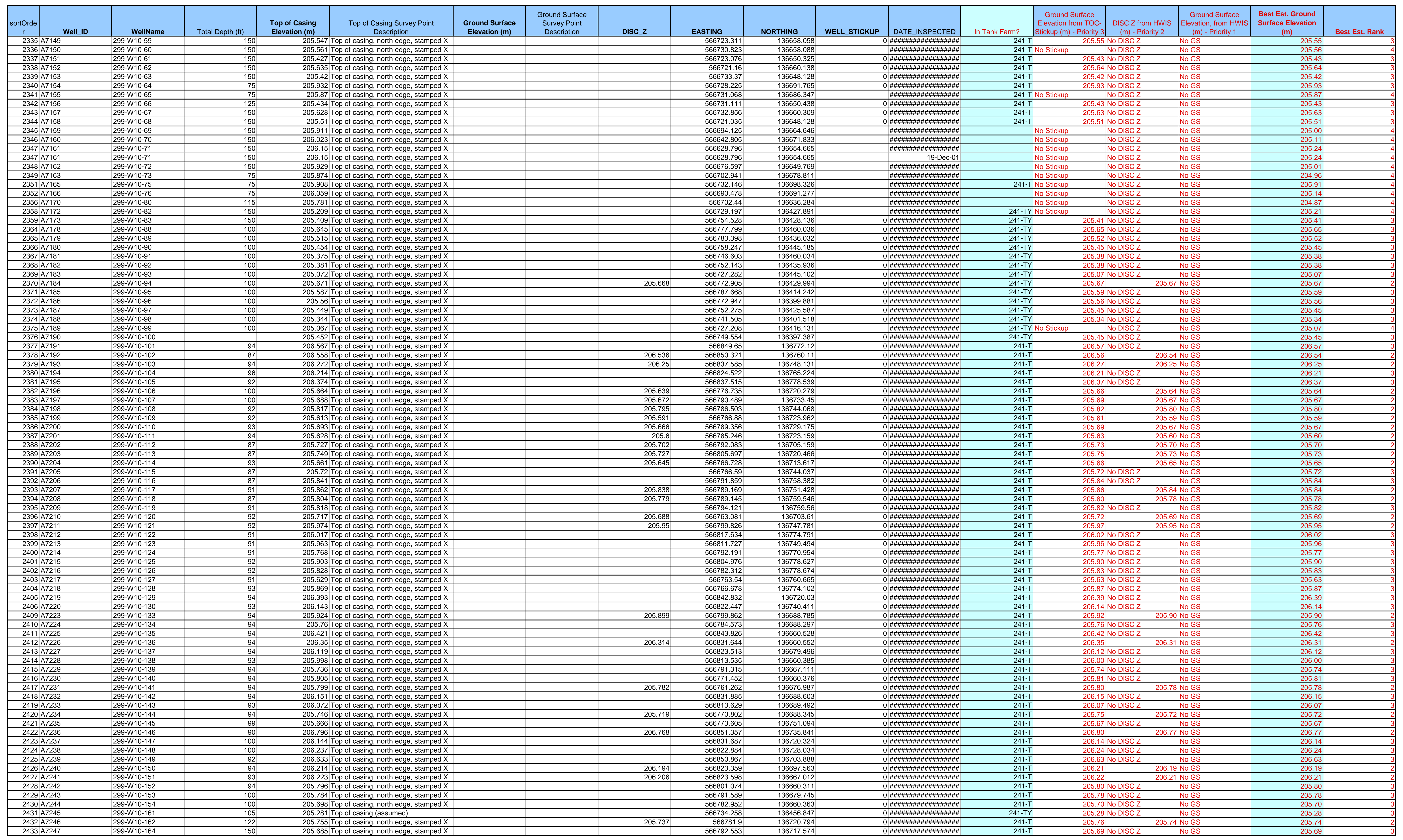




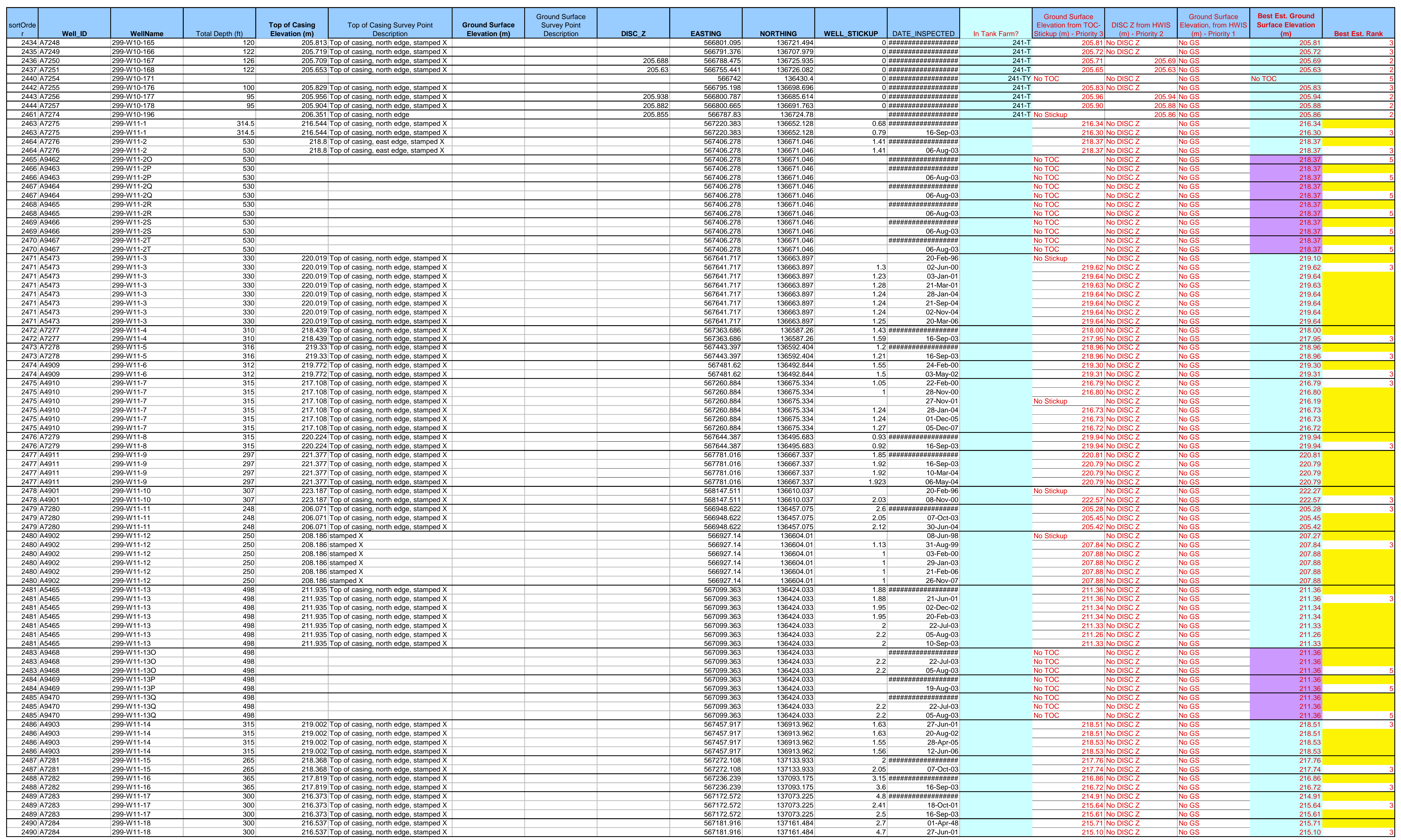




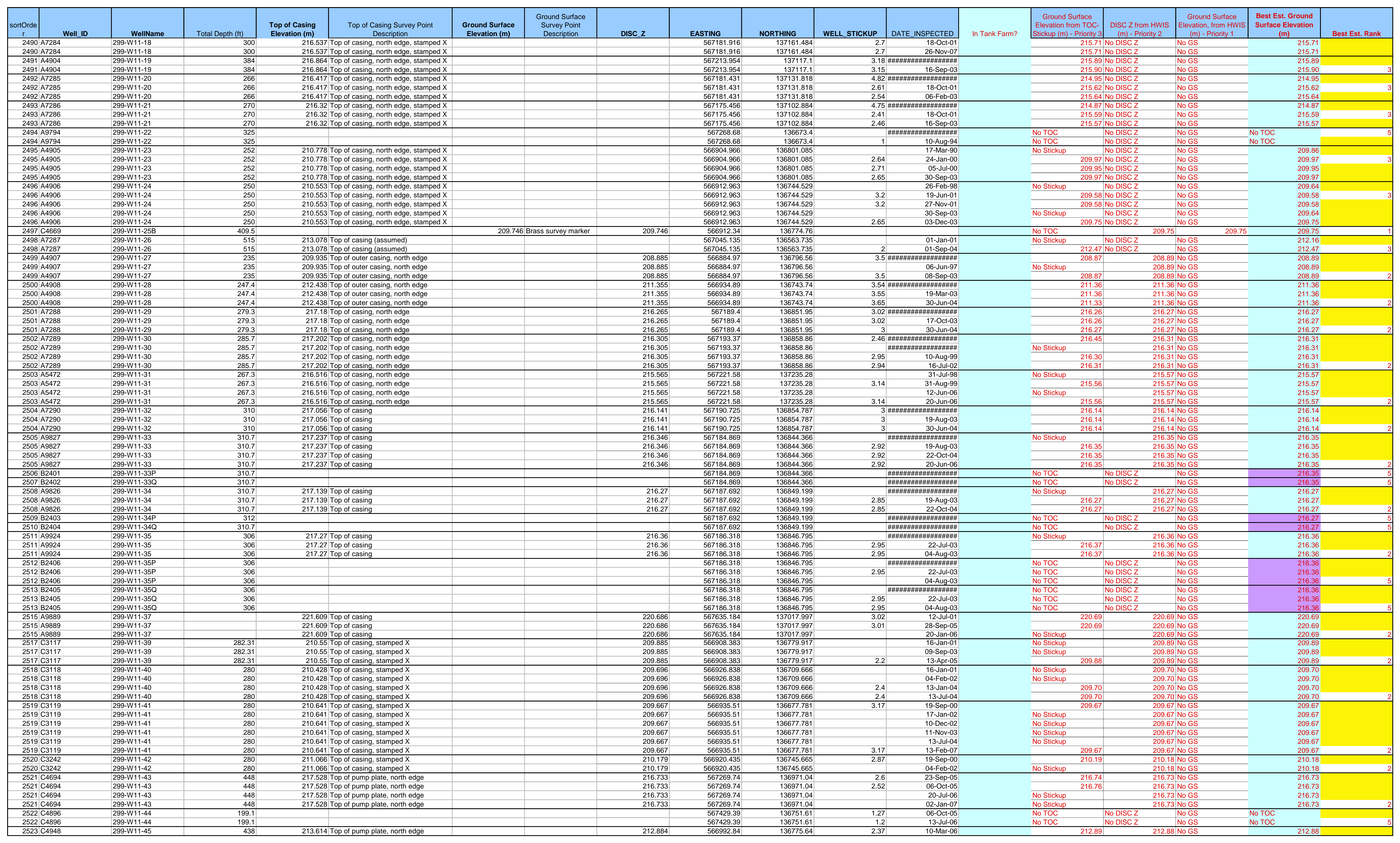




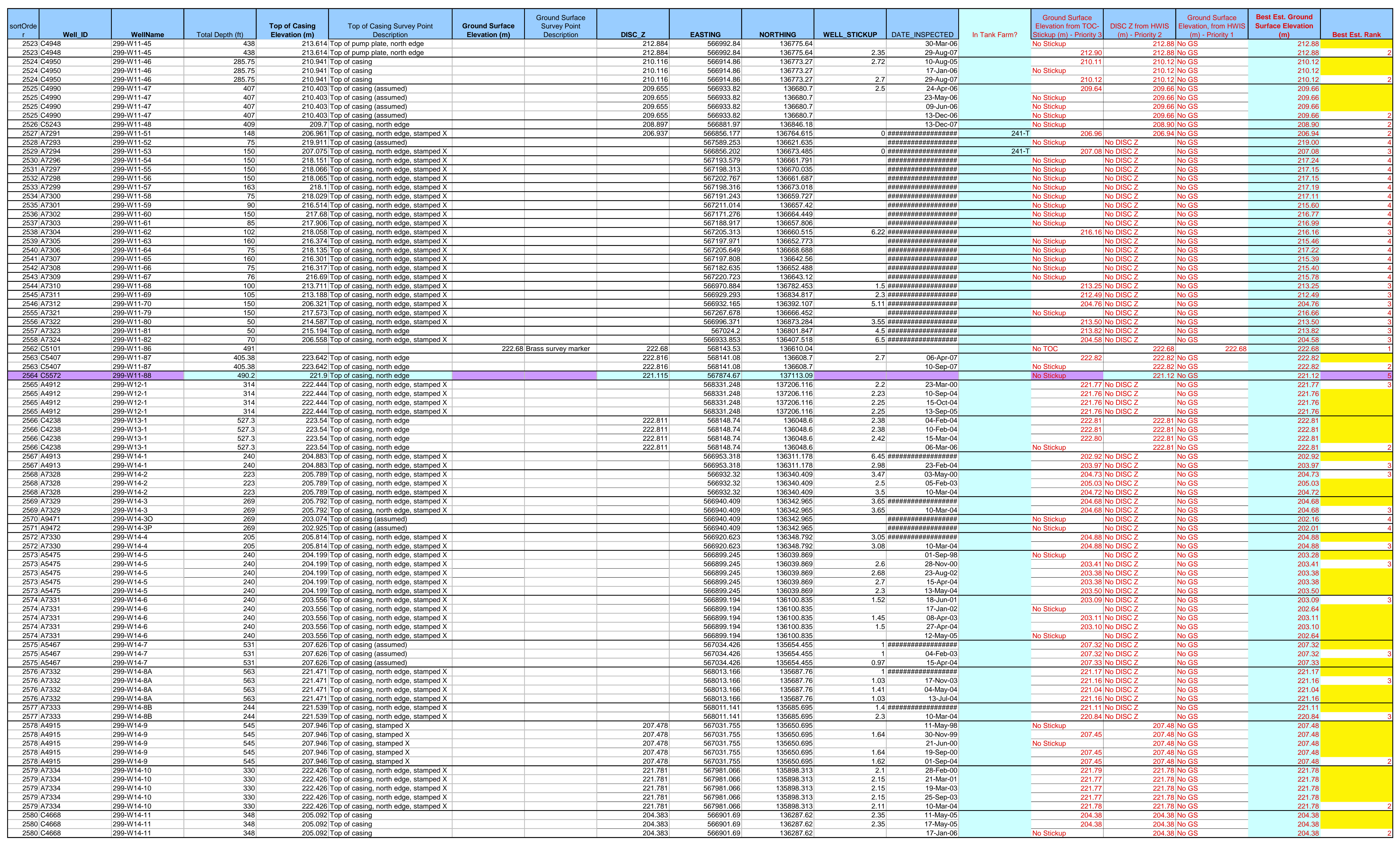




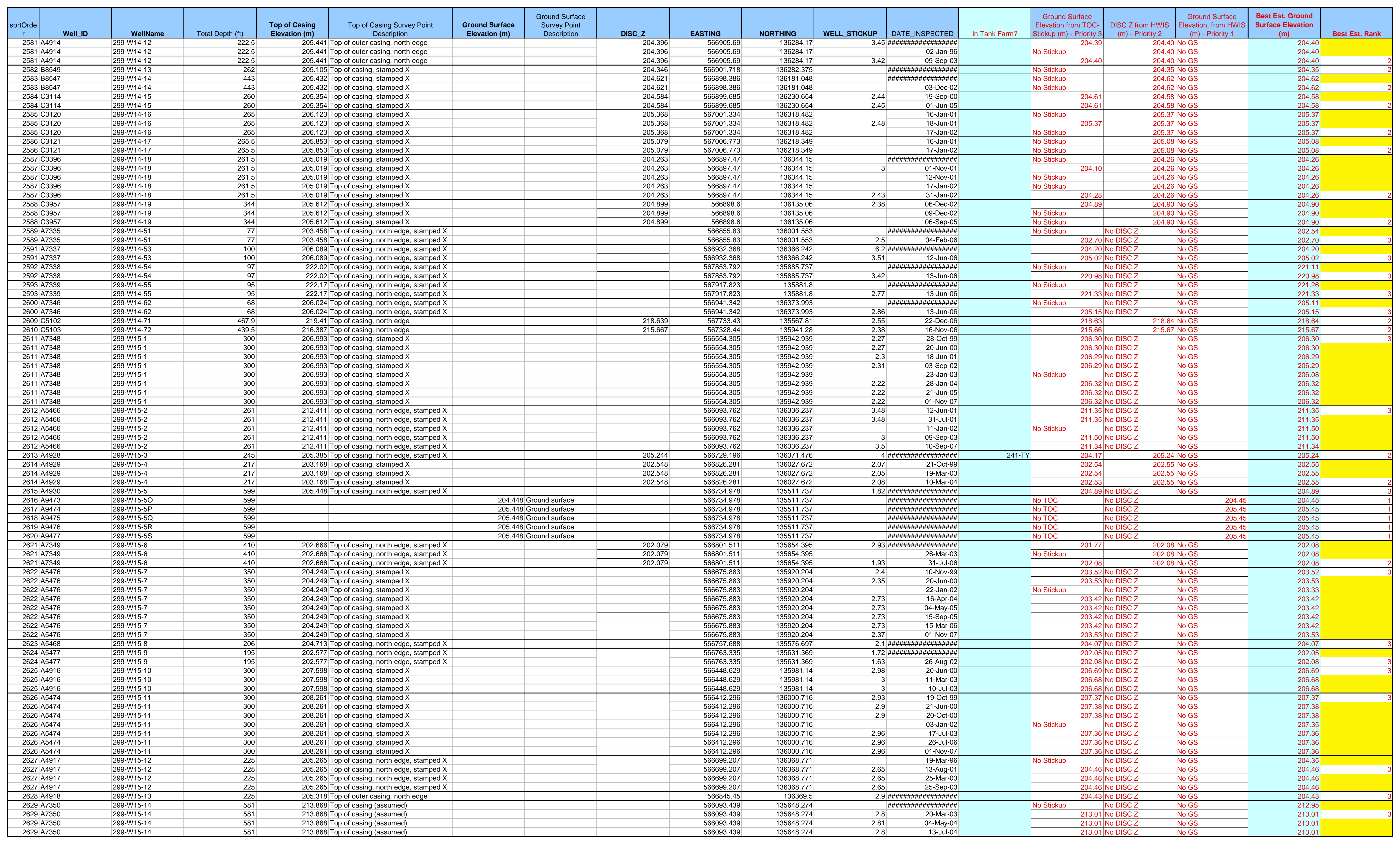




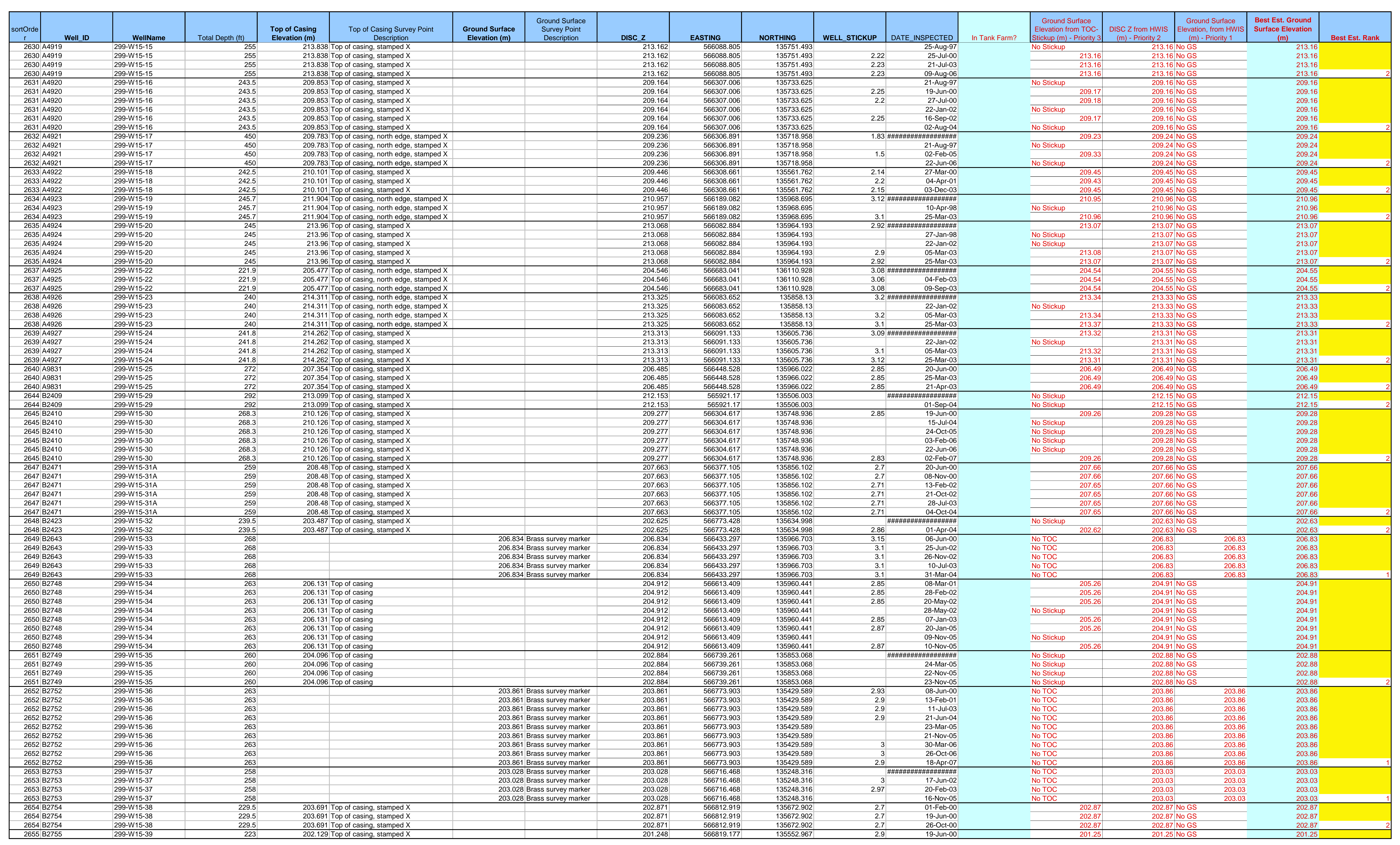




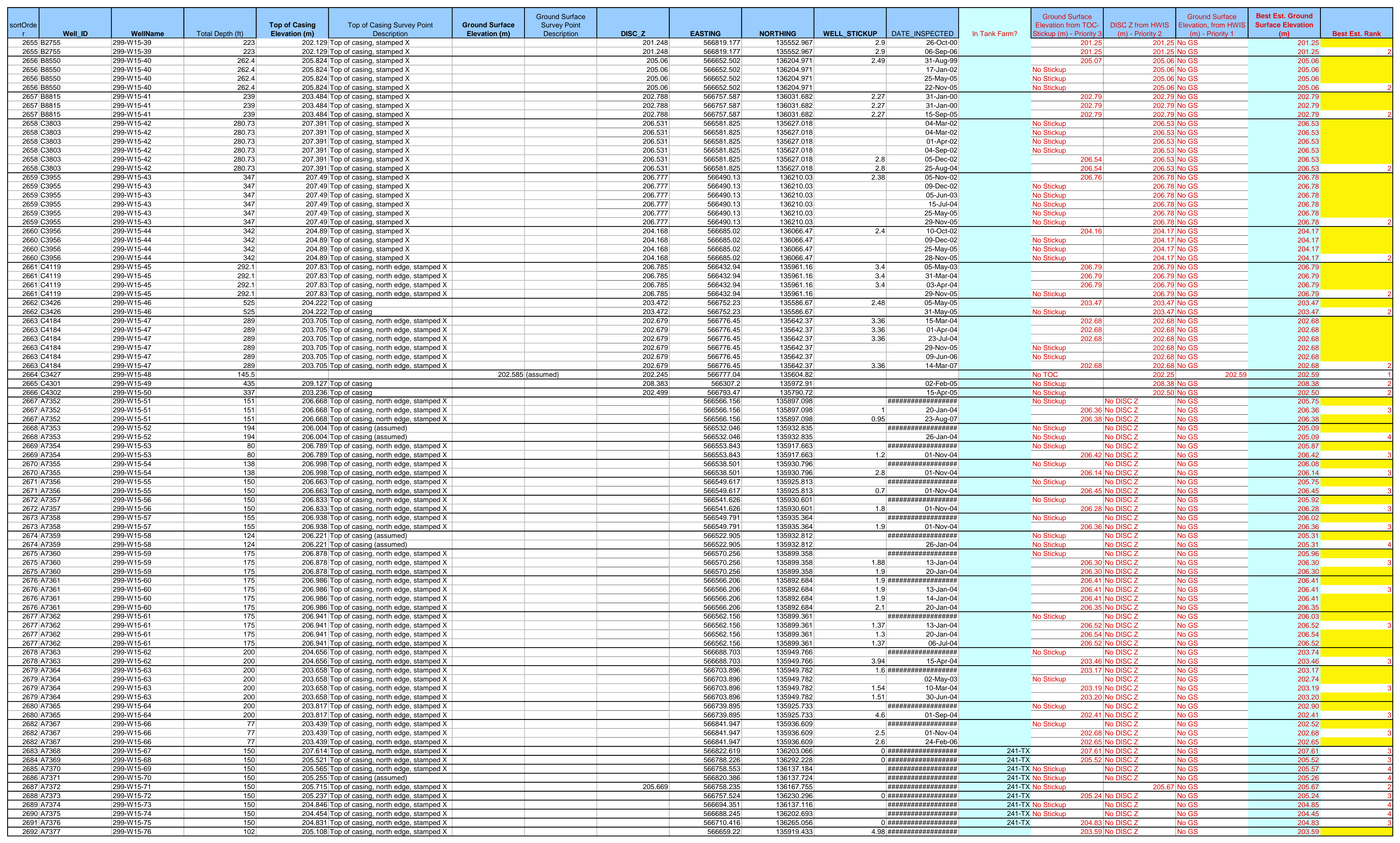




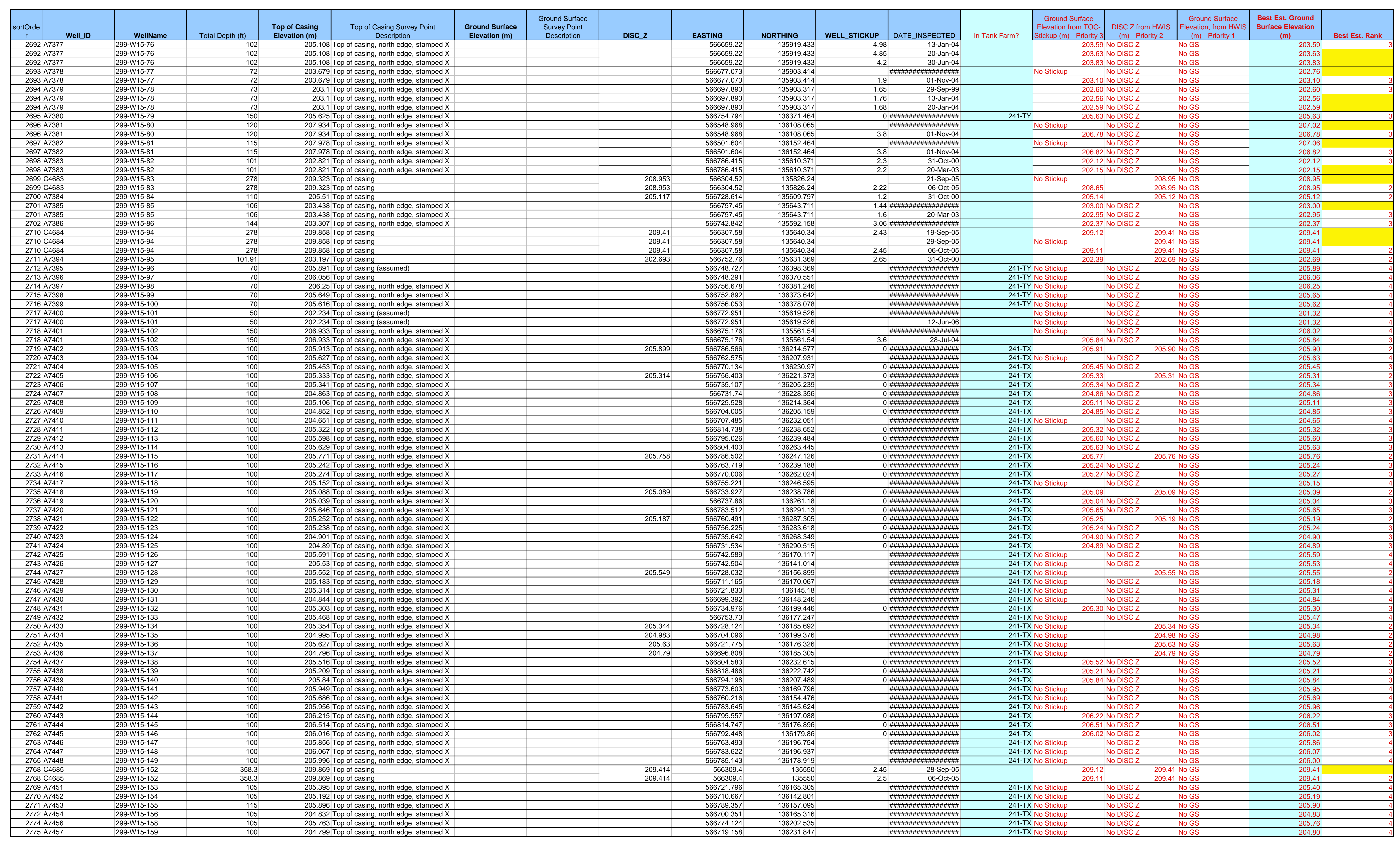




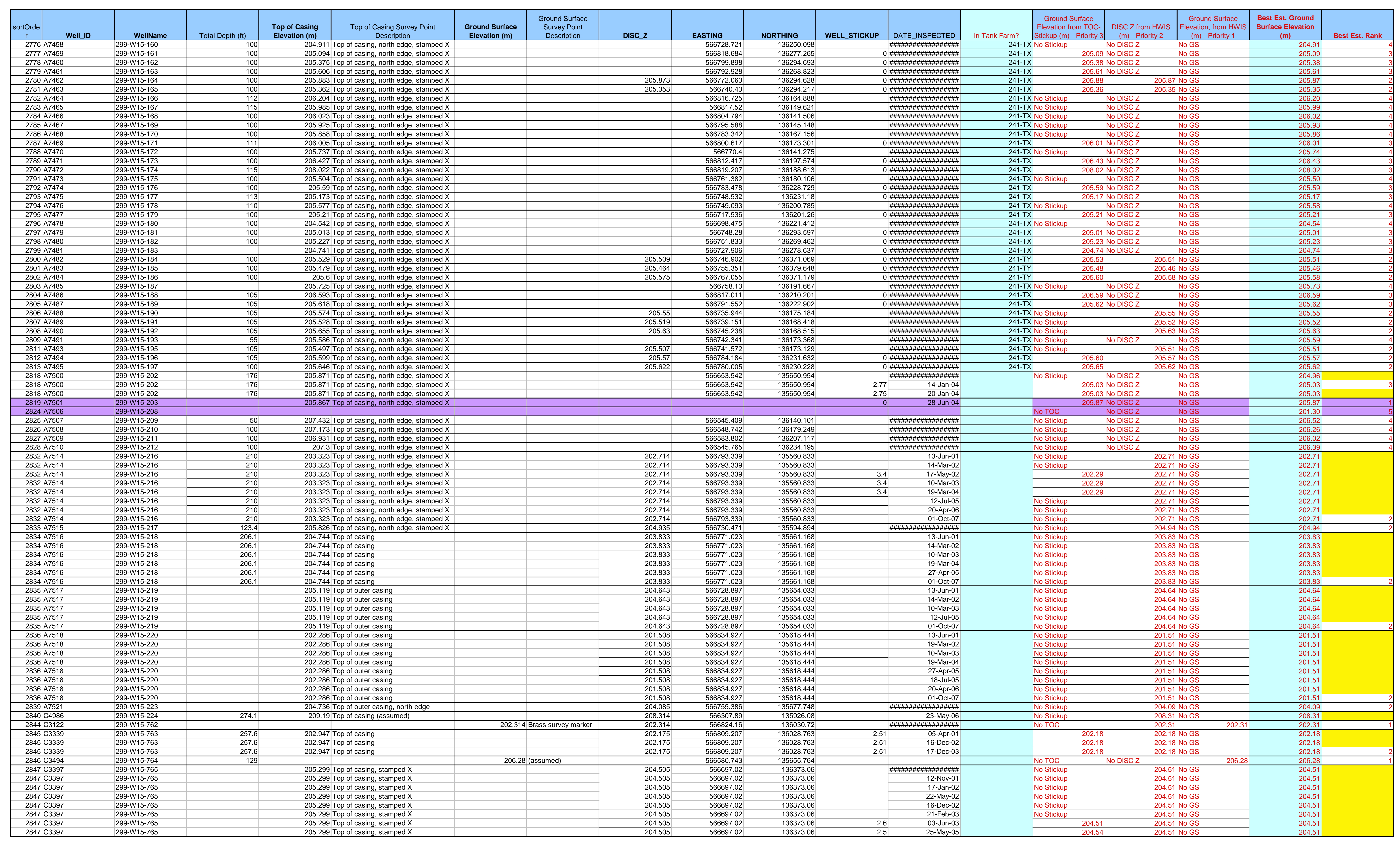




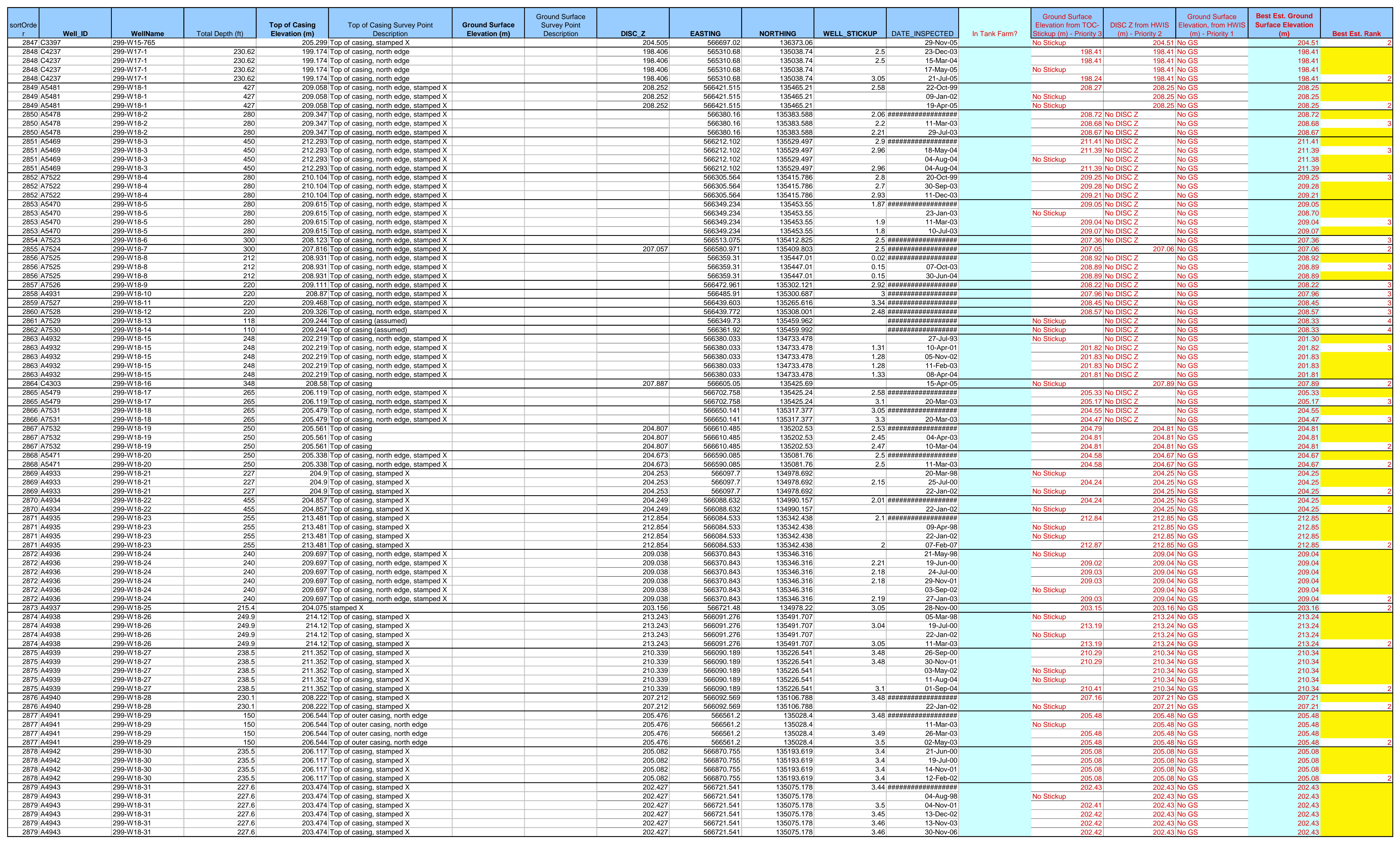




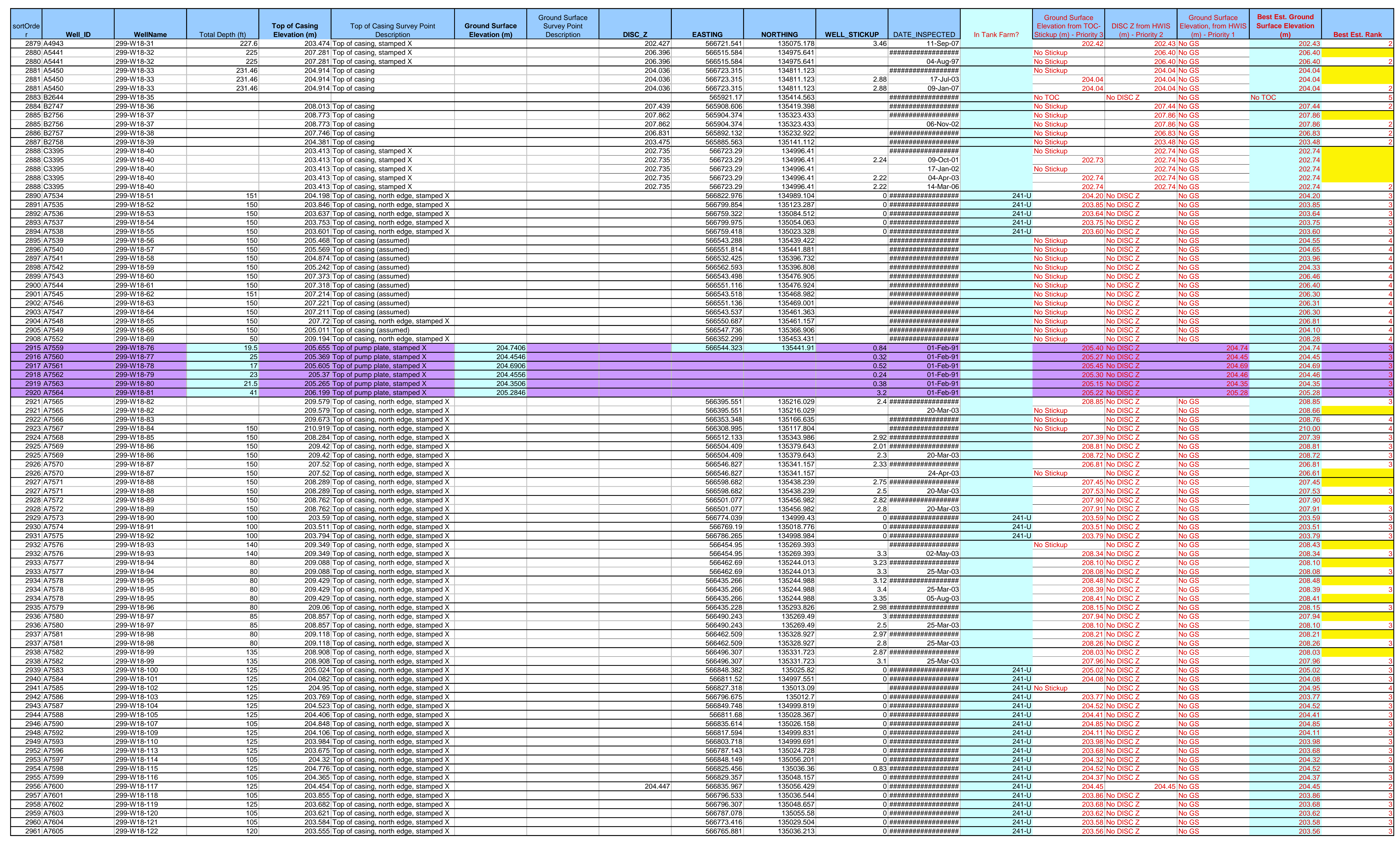




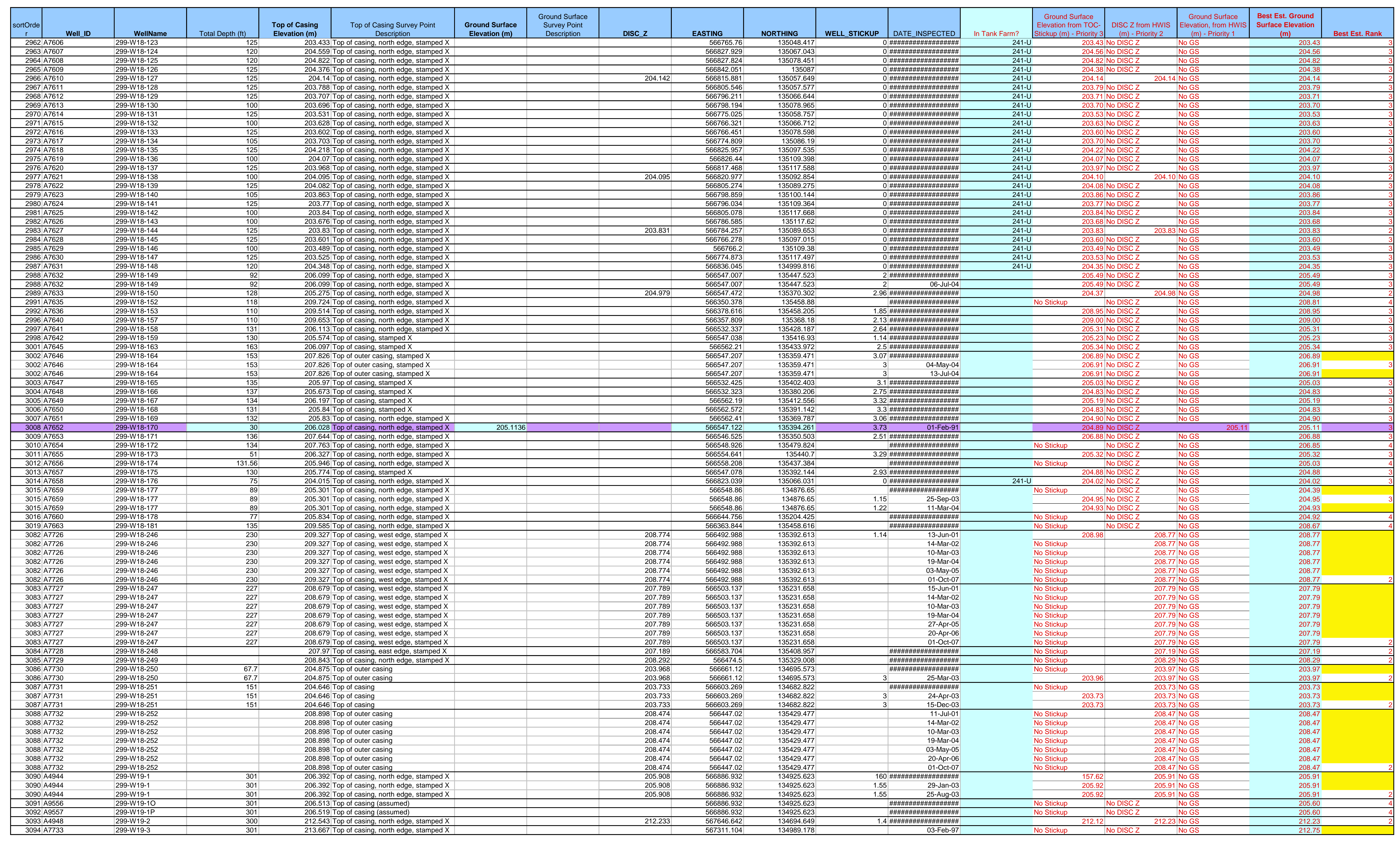




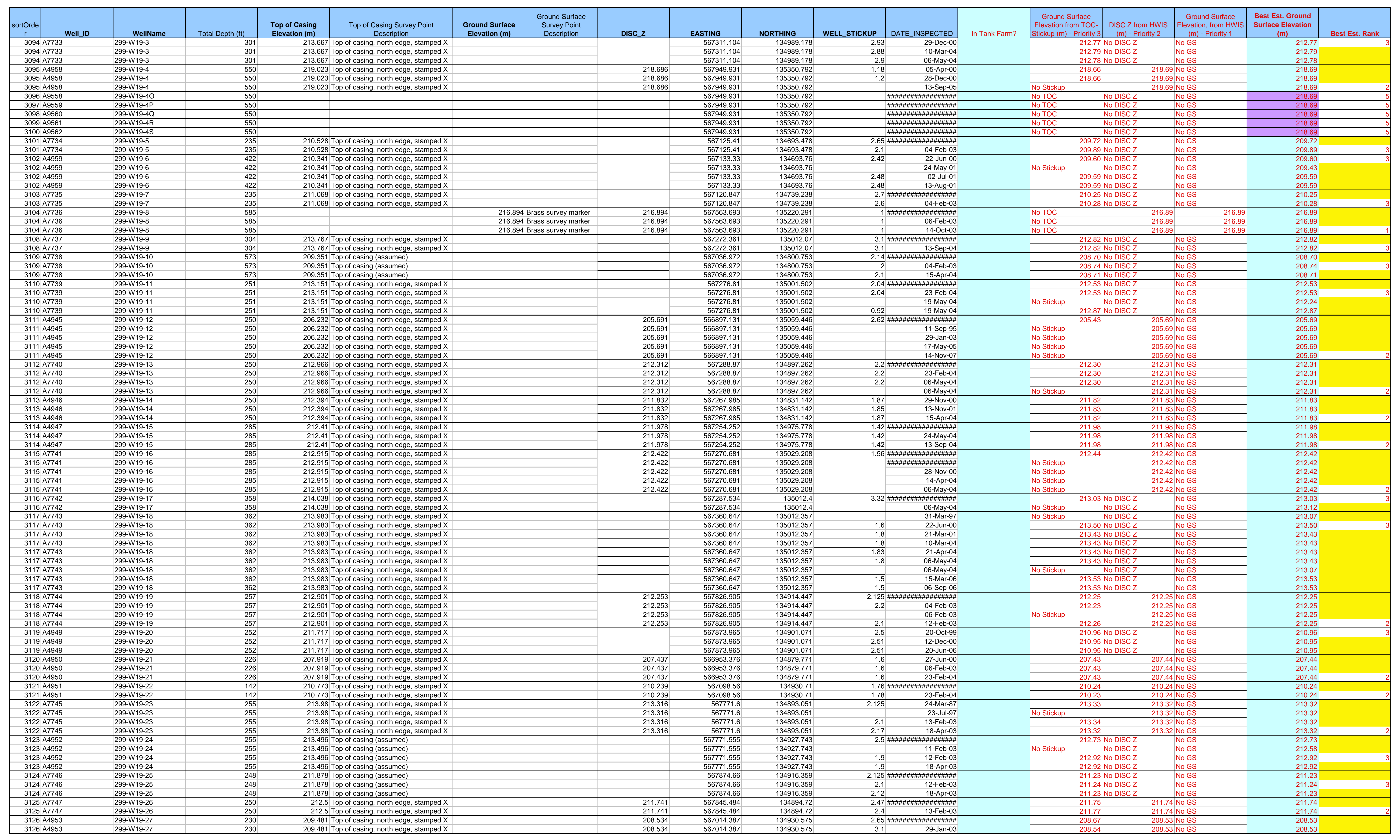




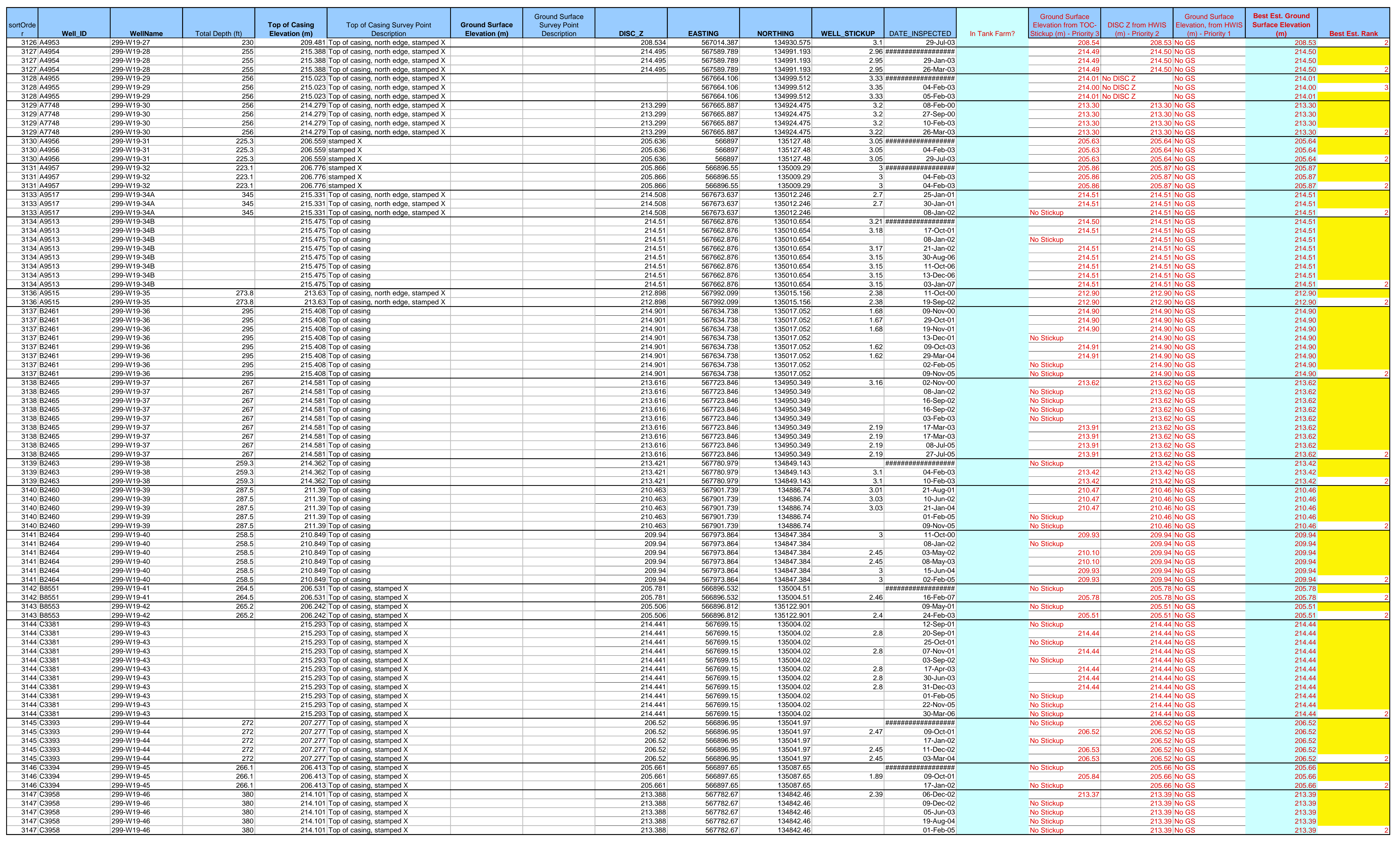




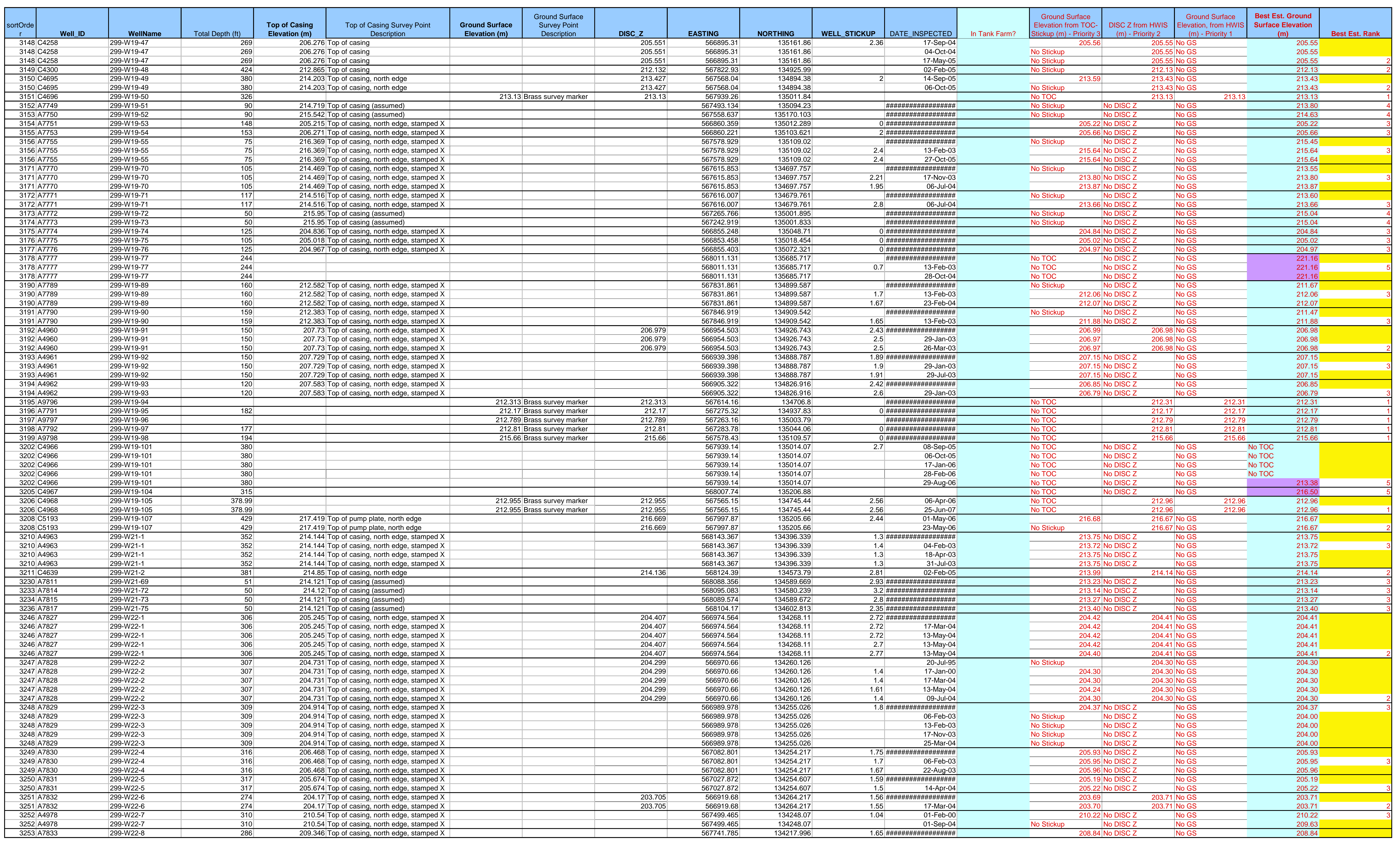




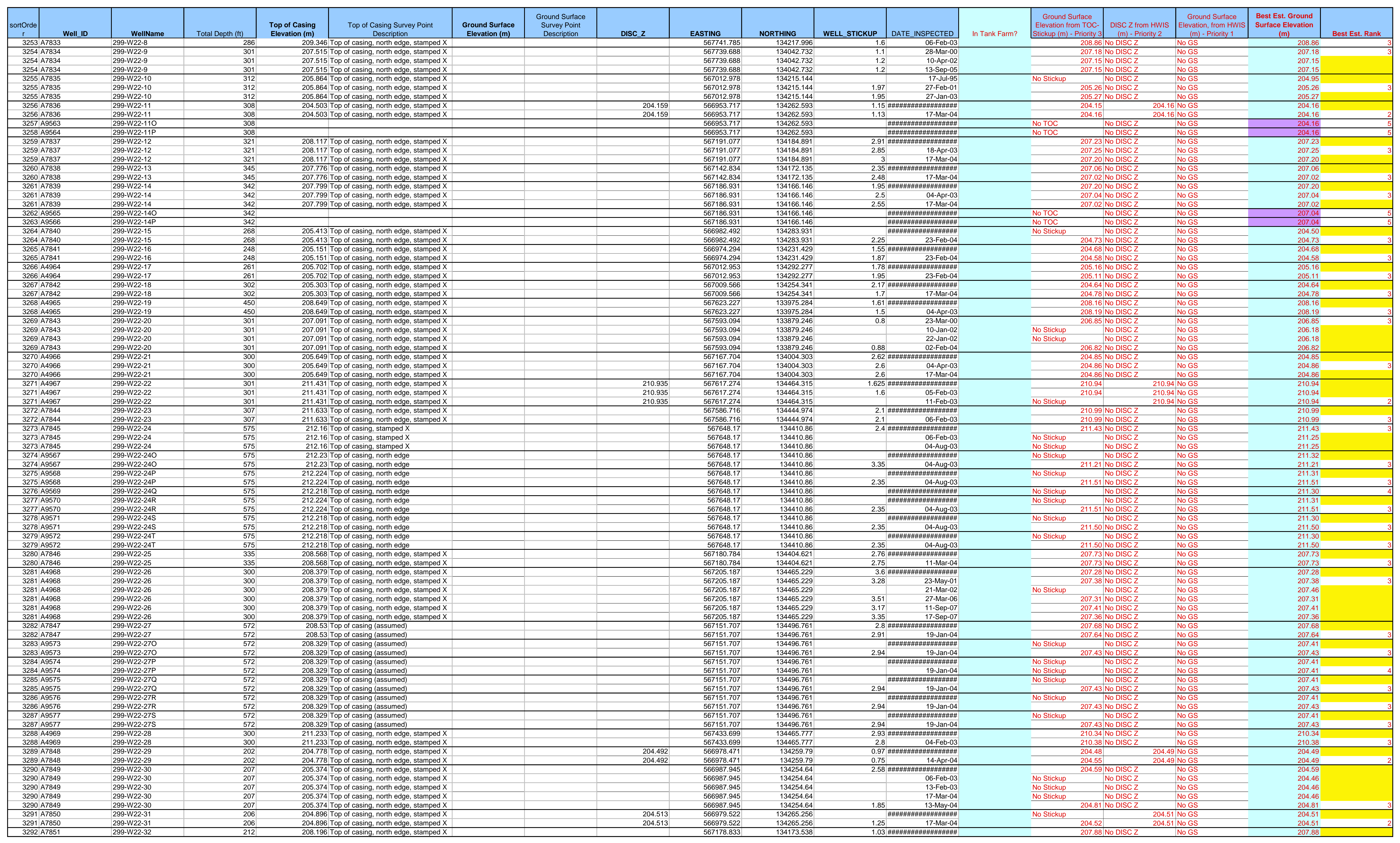




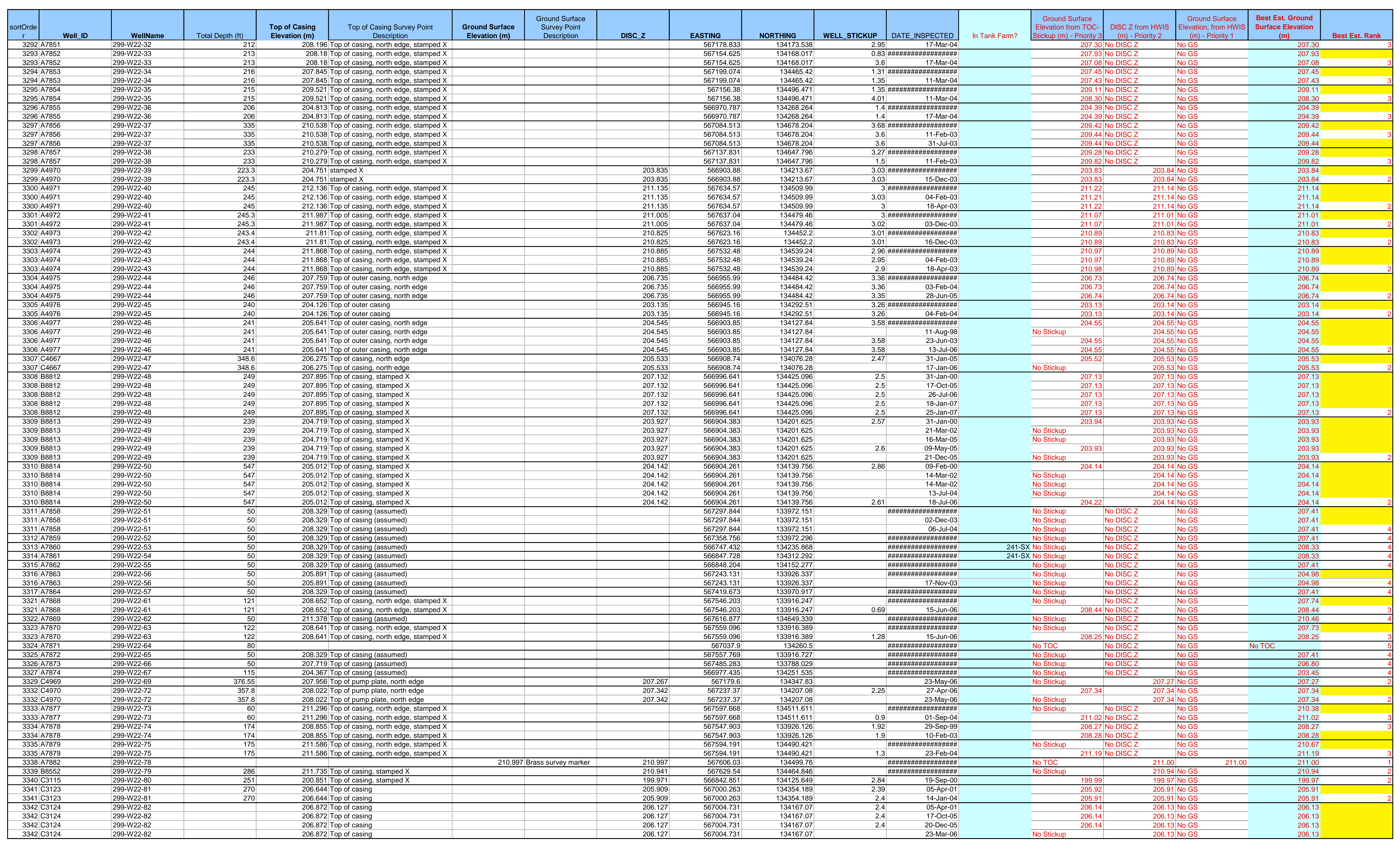




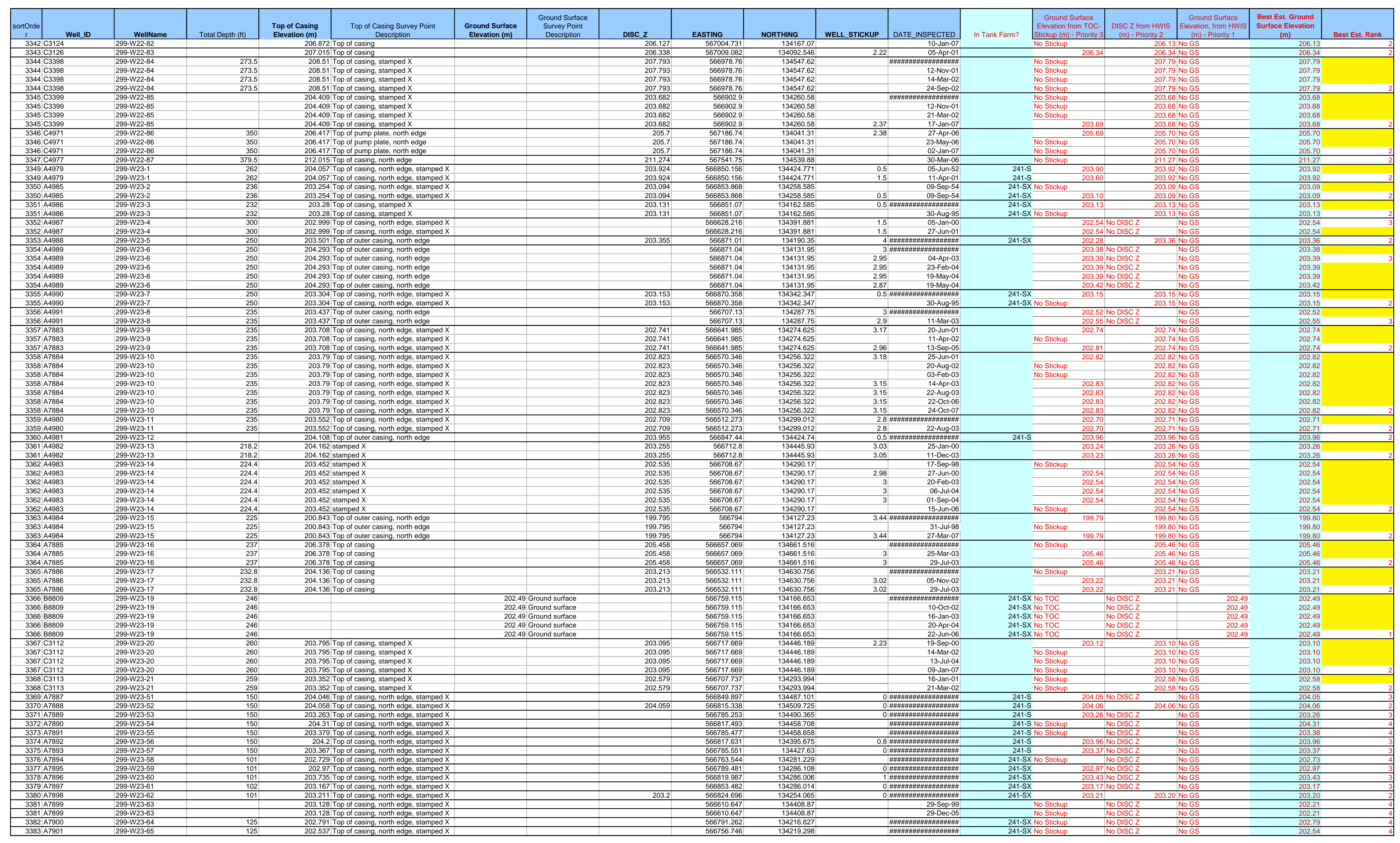




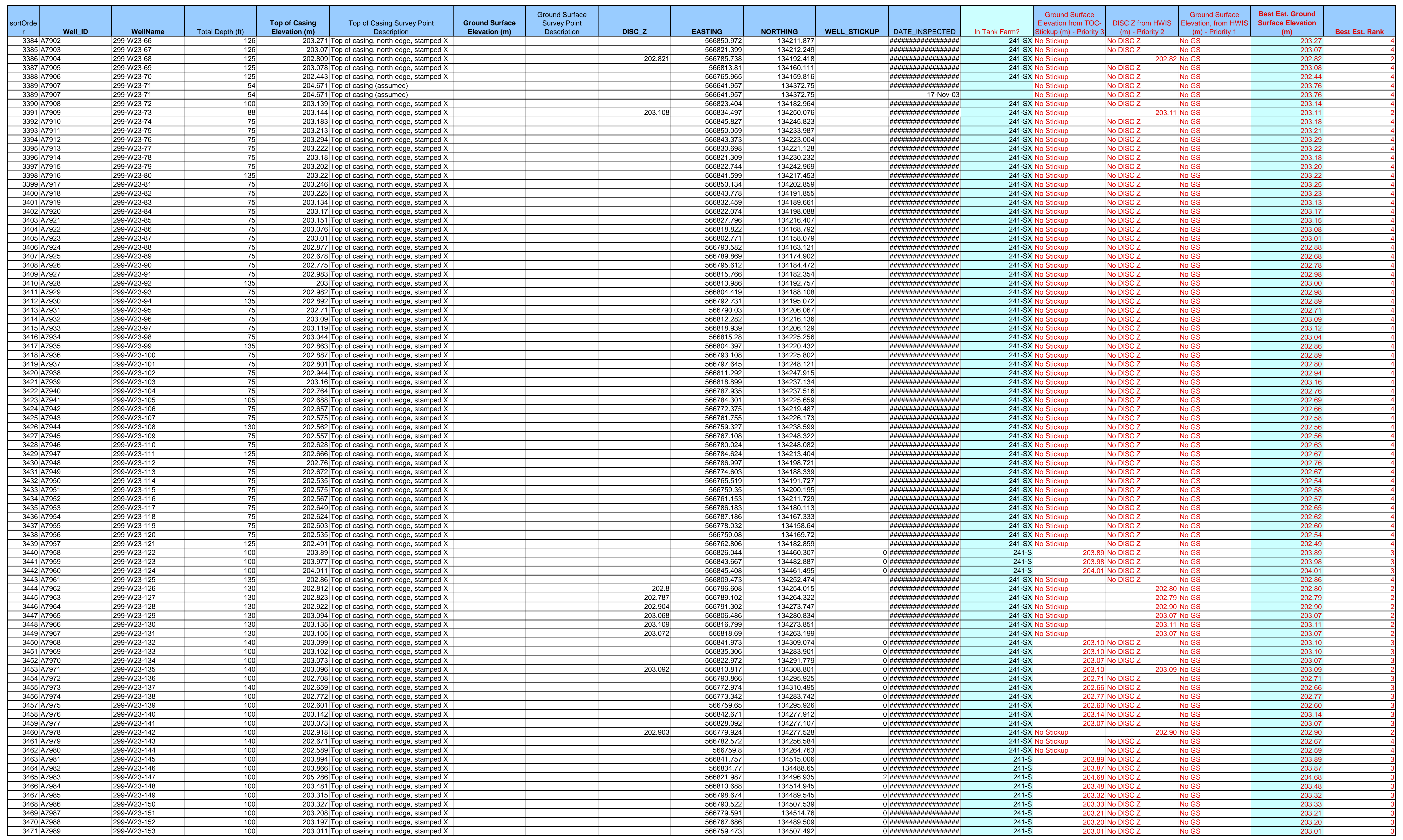




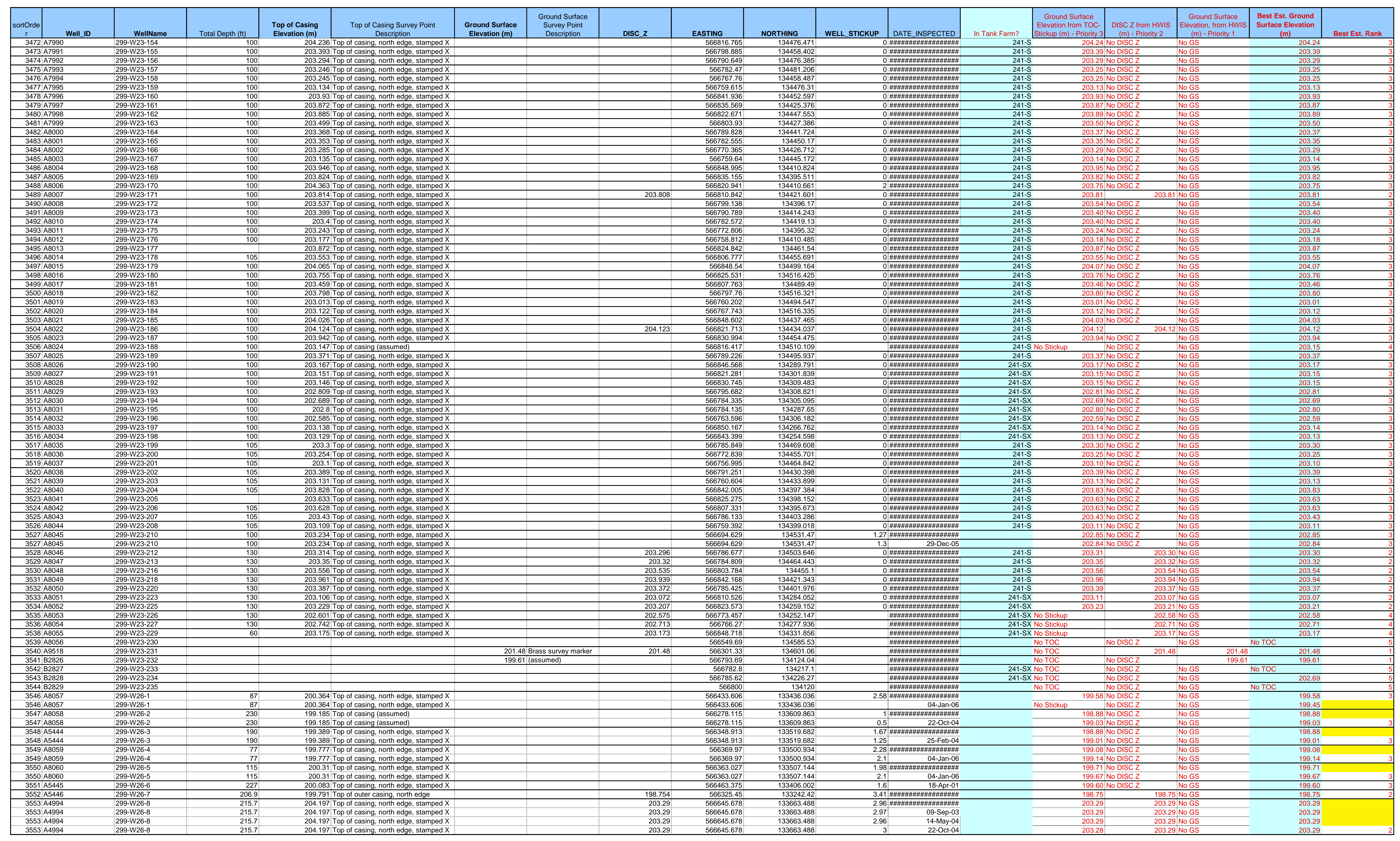




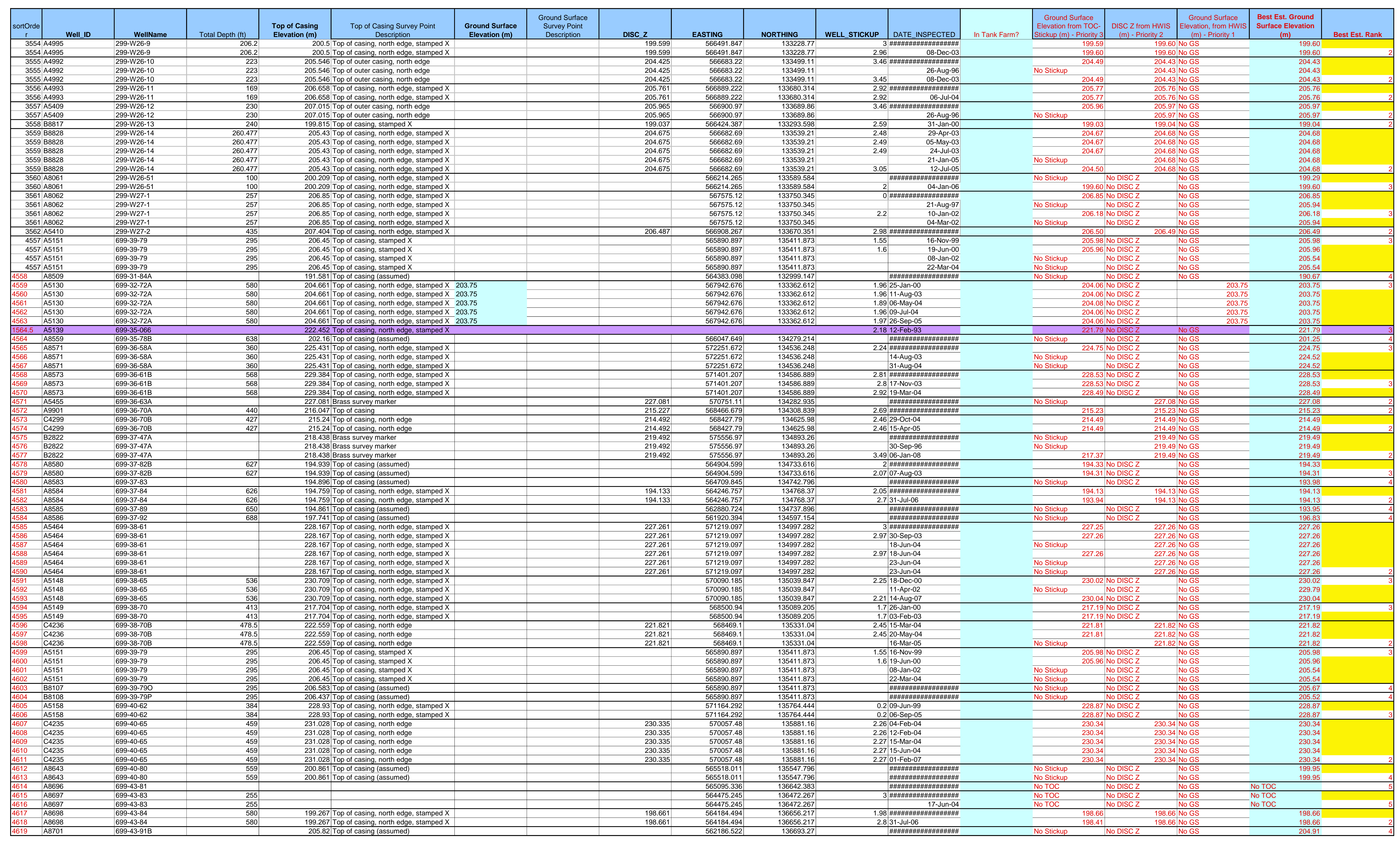




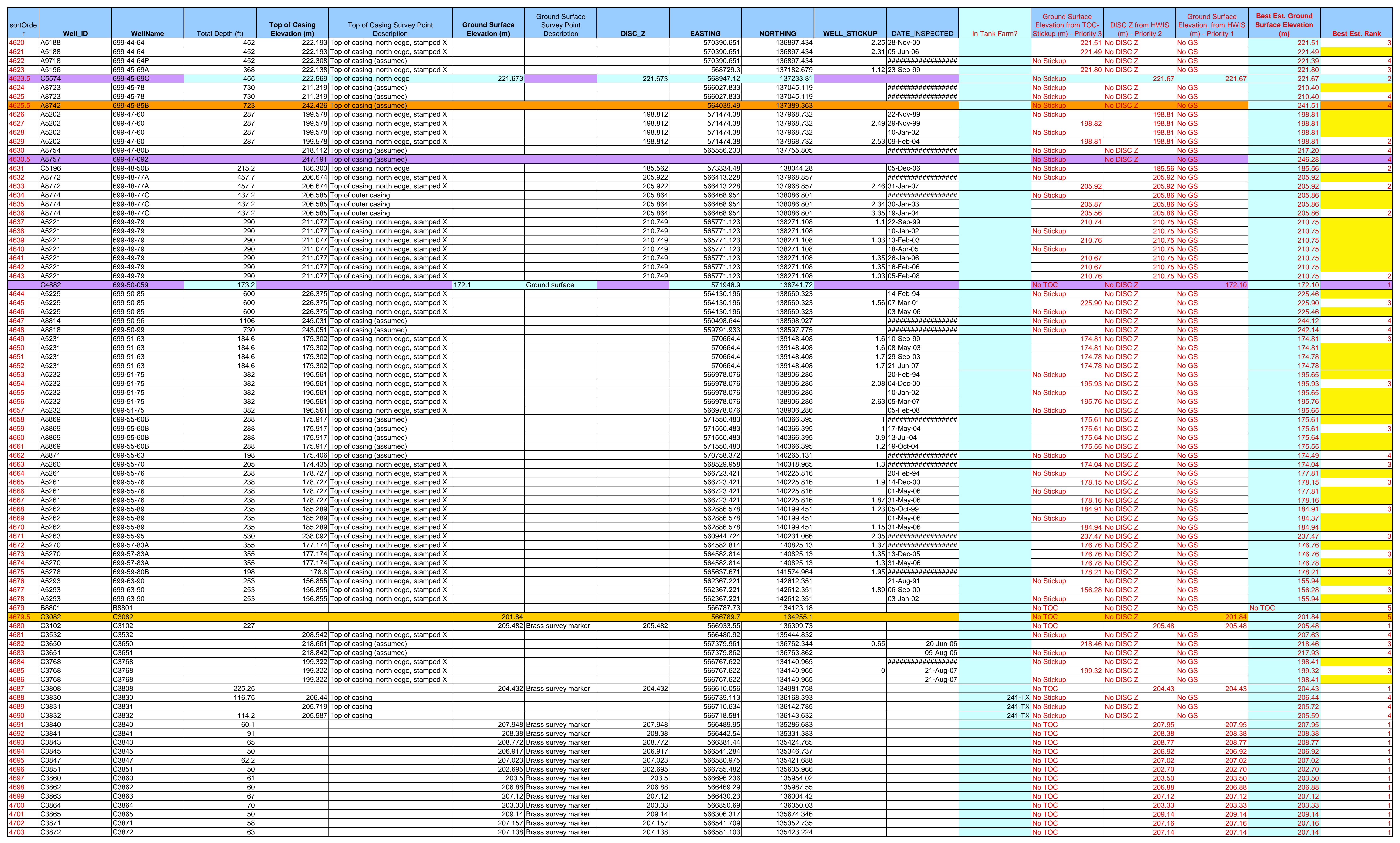




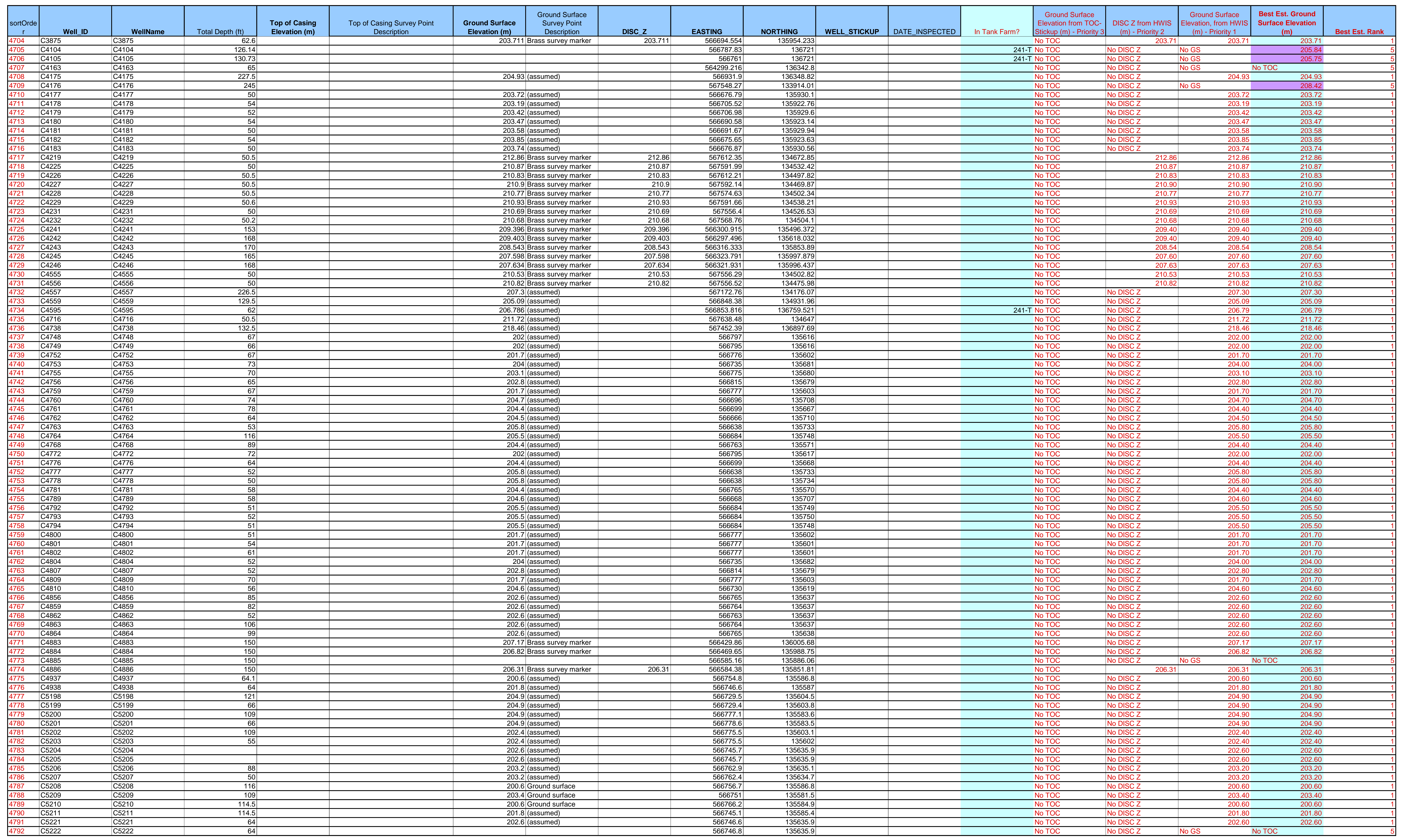




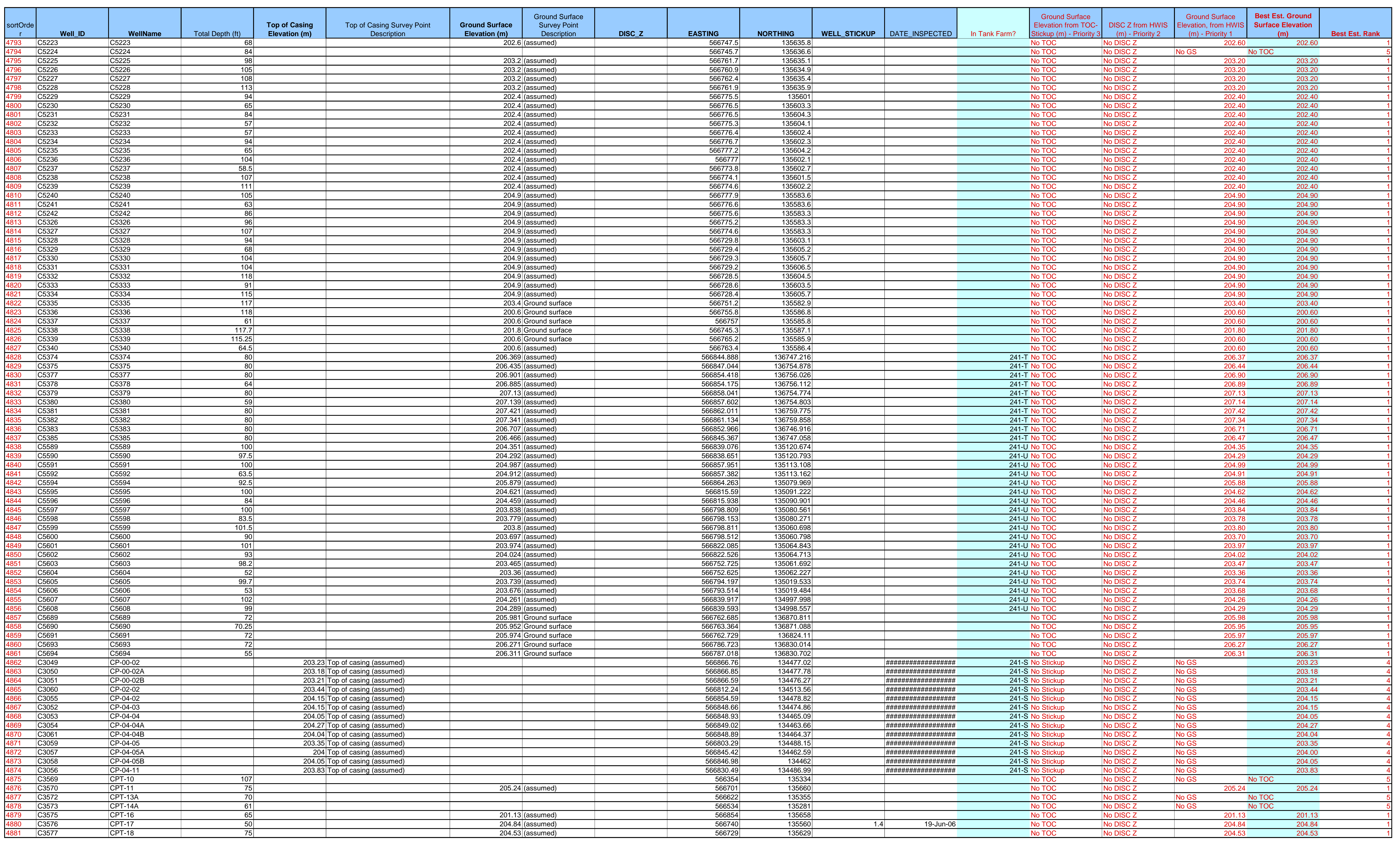




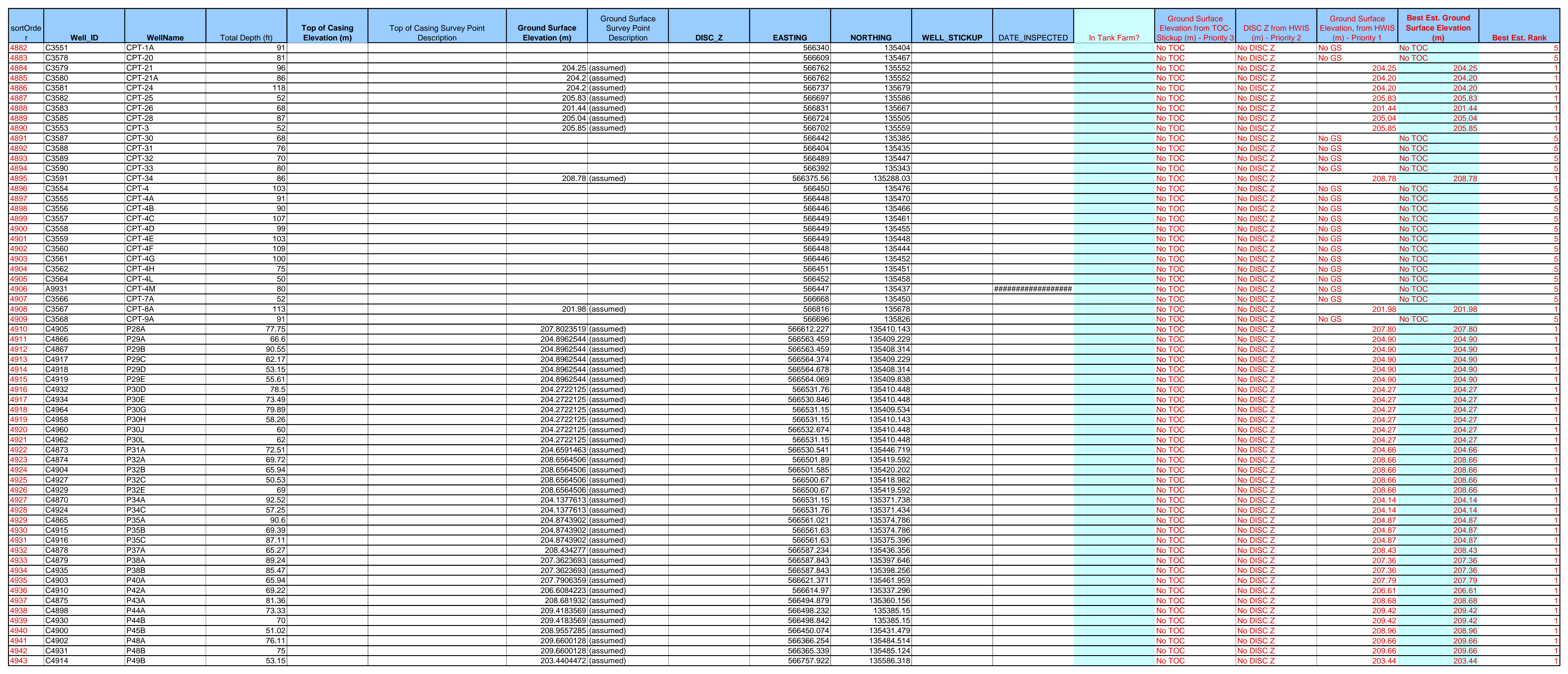




\section{Appendix C}

\section{Geologic Model of the 200 West Area}




\section{Appendix C}

\section{Geologic Model of the 200 West Area}

\section{Figures}

C.1 EarthVision Model Domain for the 200 West Area Geologic Model ................................... C.3

C.2 Structure Contour Map for the Top of the Hanford H1 Unit in and Around the 200 West Area

C.3 Structure Contour Map for the Top of the Hanford H2 Unit in and Around the 200 West Area.

C.4 Structure Contour Map for the Top of the Hanford H3 Unit in and Around the 200 West Area.

C.5 Structure Contour Map for the Top of the Cold Creek Unit Silt in and Around the 200 West Area

C.6 Structure Contour Map for the Top of the Cold Creek Unit Carbonate Unit in and Around the 200 West Area

C.7 Structure Contour Map for the Top of the Ringold Formation, Member of Taylor Flat, in and Around the 200 West Area

C.8 Structure Contour Map of the Top of the Ringold Formation, Member of Wooded Island, Unit E, in and Around the 200 West Area

C.9 Structure Contour Map of the Top of the Ringold Formation, Lower Mud Unit, in and Around the 200 West Area

C.10 Structure Contour Map of the Top of the Ringold Formation, Member of Wooded Island, Unit A, in and Around the 200 West Area.

C.11 Structure Contour Map of the Top of Basalt in and Around the 200 West Area

C.12 Isopach Map of Holocene Deposits in and Around the 200 West Area

C.13 Isopach Map of the Hanford H1 Unit in and Around the 200 West Area

C.14 Isopach Map of the Hanford H2 Unit in and Around the 200 West Area......

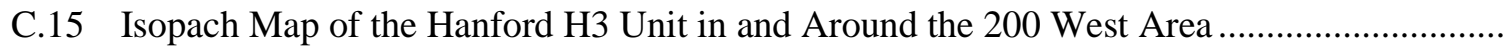


C.17 Isopach Map of the Cold Creek Unit Carbonate in and Around the 200 West Area............. C. C.19

C.18 Isopach Map of the Ringold Formation, Member of Taylor Flat, in and Around the 200 West Area

C.19 Isopach Map of the Ringold Formation, Member of Wooded Island, Unit E, in and Around the 200 West Area

C.20 Isopach Map of the Ringold Formation, Lower Mud Unit, in and Around the 200 West Area.....

C.21 Isopach Map of the Ringold Formation, Member of Wooded Island, Unit A, in and Around the 200 West Area

C.22 Cross-Section Location Map

C.23 North-South Cross Section B-B'

C.24 East-West Cross Section F-F'

C.25 East-West Cross Section I-I’

C.26 Three-Dimensional Solid Earth Model with Cutout Along Cross Sections B-B' and I-I'

C.27 Three-Dimensional Solid Earth Model with Cutout Along Cross Sections B-B' and F-F'

\section{Table}

C.1 Top Contact Elevation Data for Stratigraphic Units Used to Build EarthVision Model........ C.26 


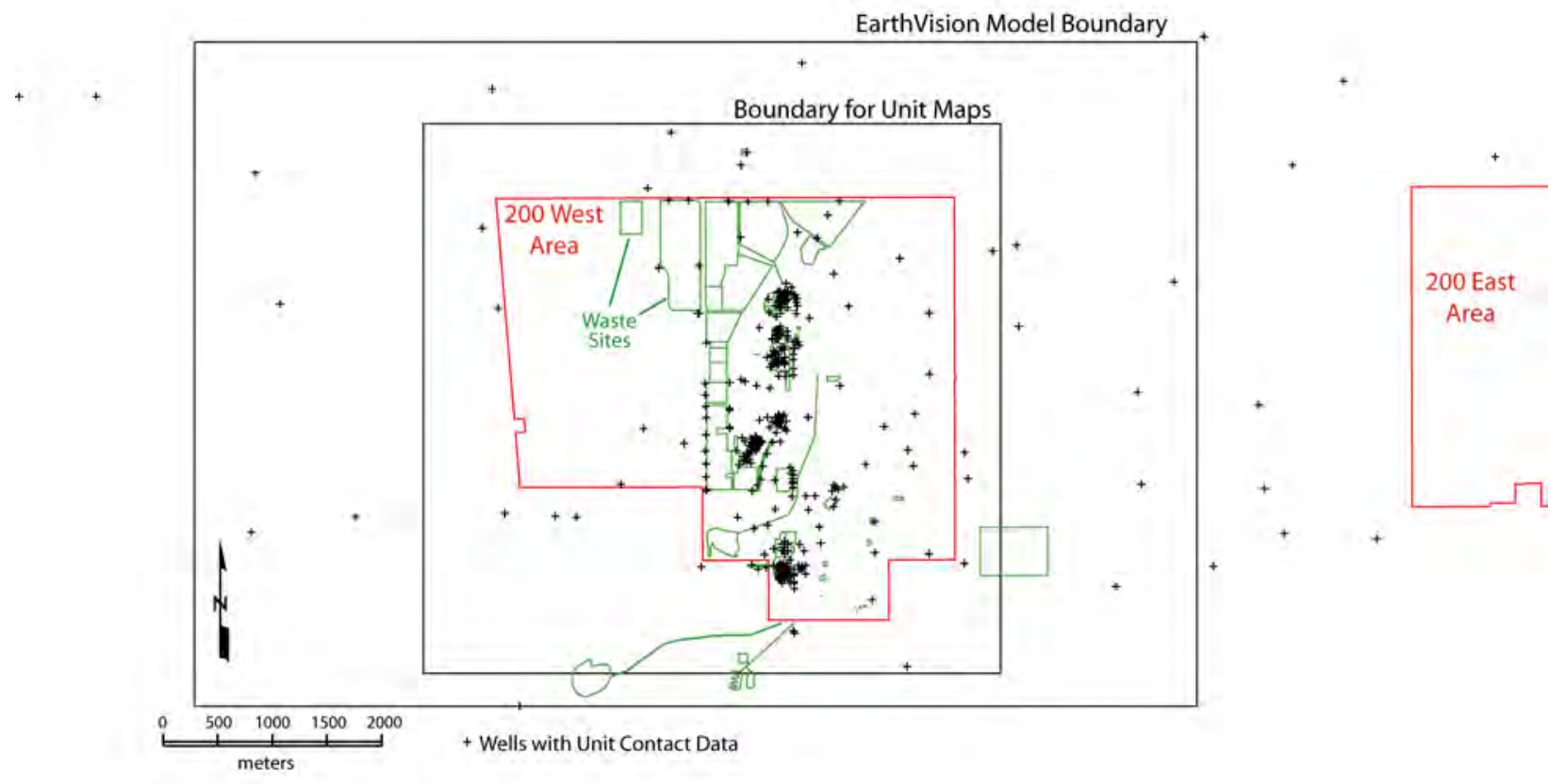

Figure C.1. EarthVision Model Domain for the 200 West Area Geologic Model. Note that the model boundary extends beyond the study area boundary used in subsequent figures, to reduce edge effects. 


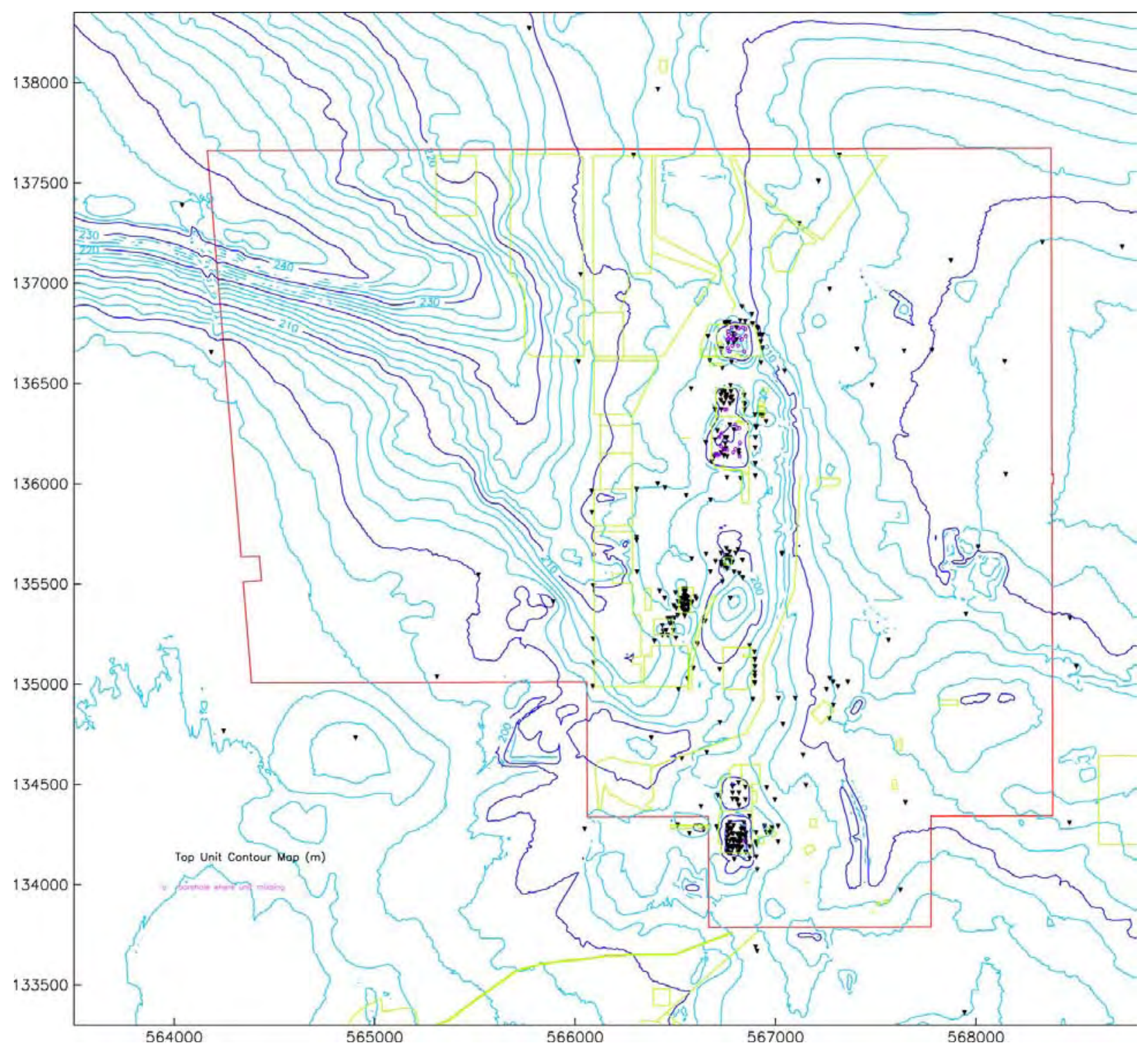

Figure C.2. Structure Contour Map for the Top of the Hanford H1 Unit in and Around the 200 West Area. The irregular surface in the central and southern 200 West Area is due to man-made excavations associated with subsurface facilities (e.g., tank farms). Contours are in meters above mean sea level (MSL). 


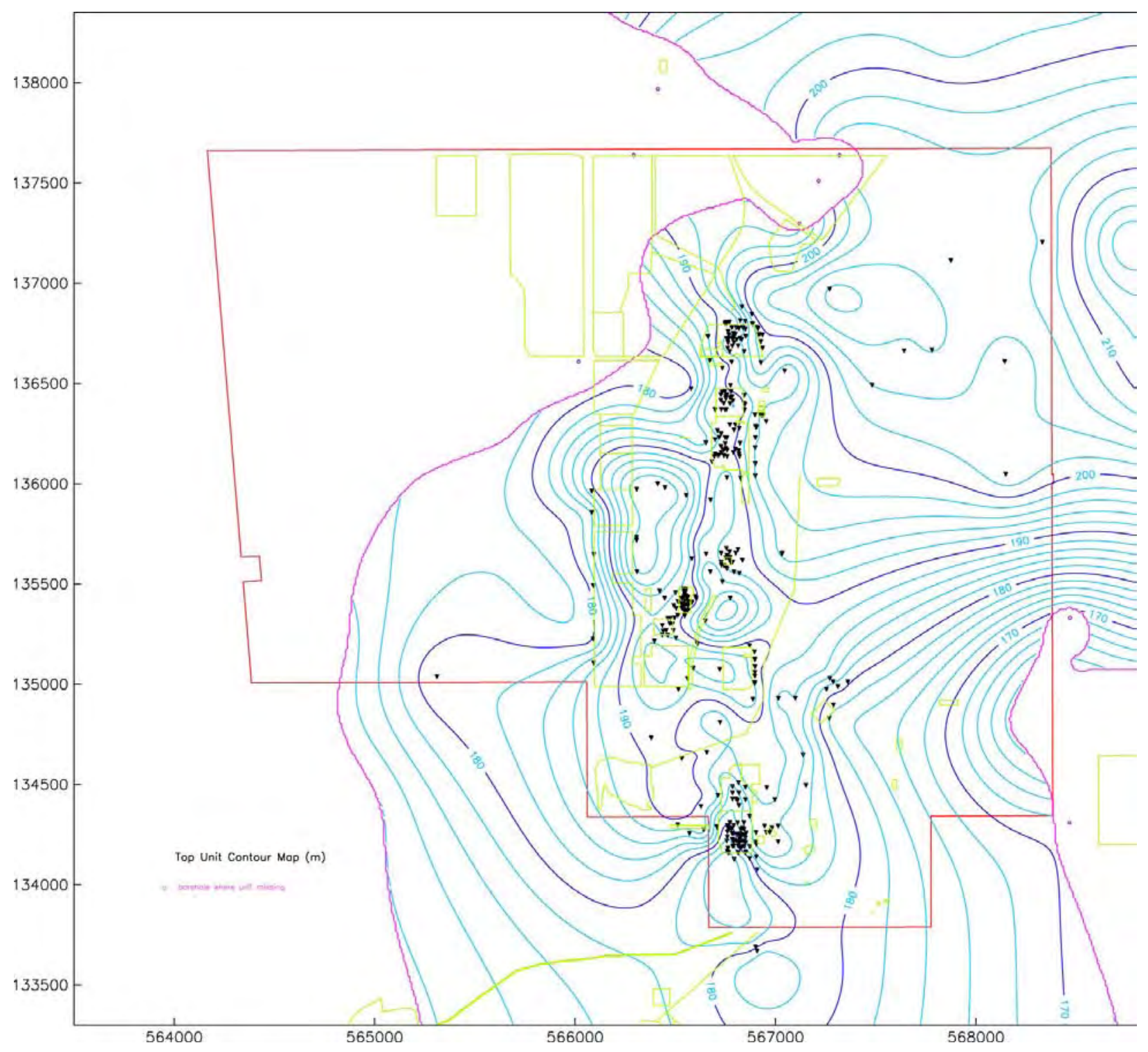

Figure C.3. Structure Contour Map for the Top of the Hanford H2 Unit in and Around the 200 West Area. Contours are in meters above mean sea level (MSL). 


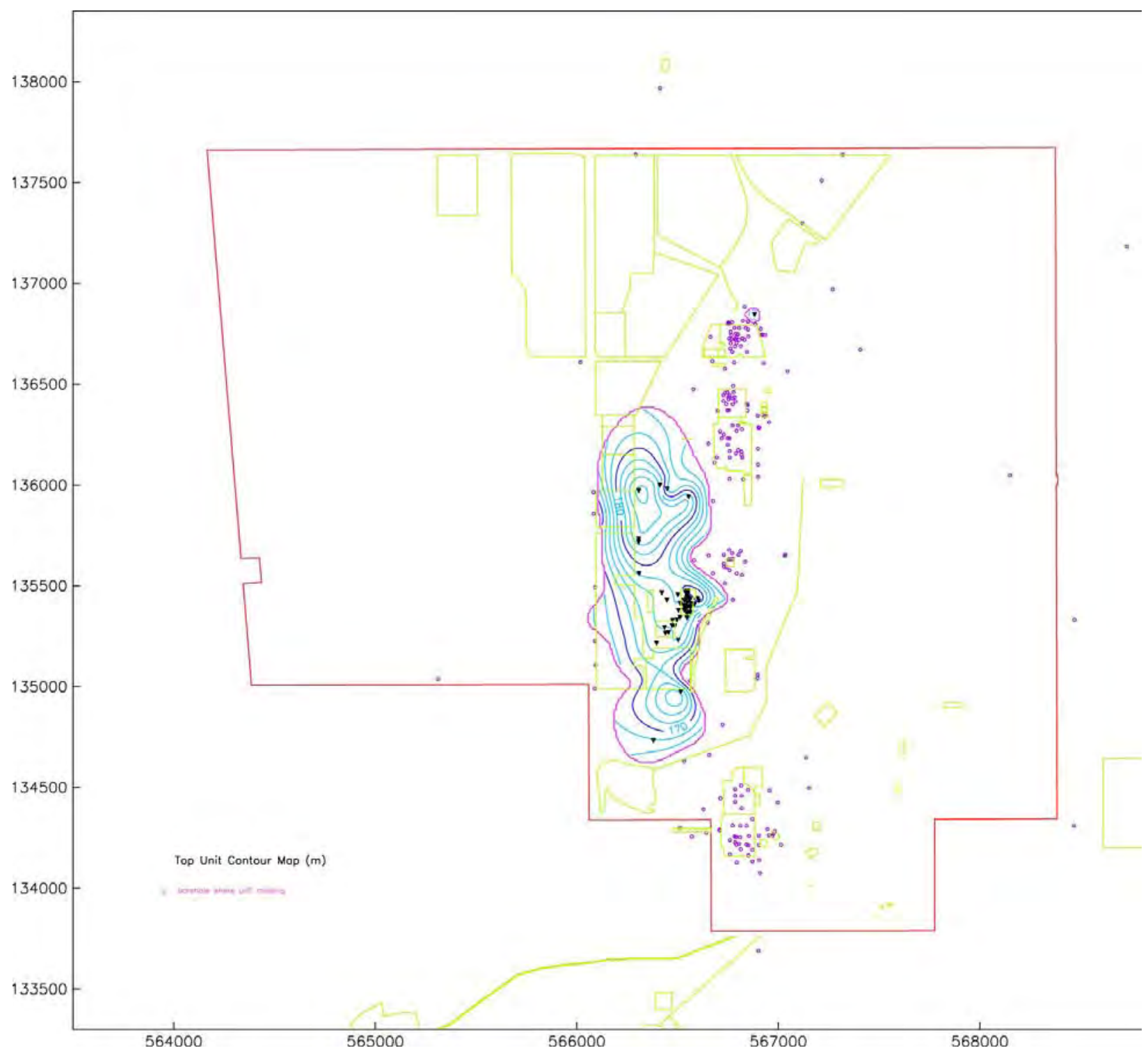

Figure C.4. Structure Contour Map for the Top of the Hanford H3 Unit in and Around the 200 West Area. Contours are in meters above mean sea level (MSL). 


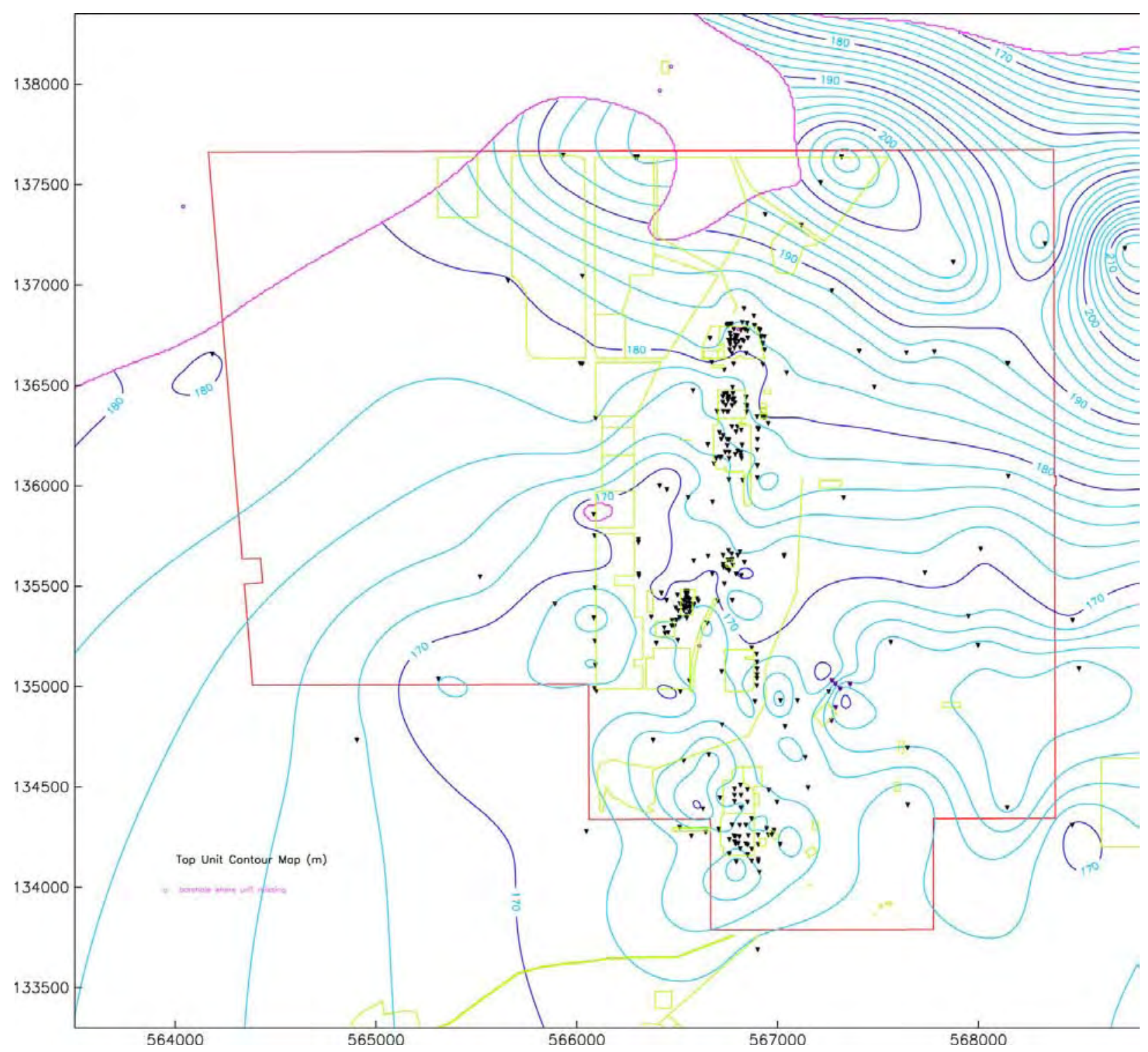

Figure C.5. Structure Contour Map for the Top of the Cold Creek Unit Silt in and Around the 200 West Area. Contours are in meters above mean sea level (MSL). Note that this unit is missing along the northern portion of the study area. 


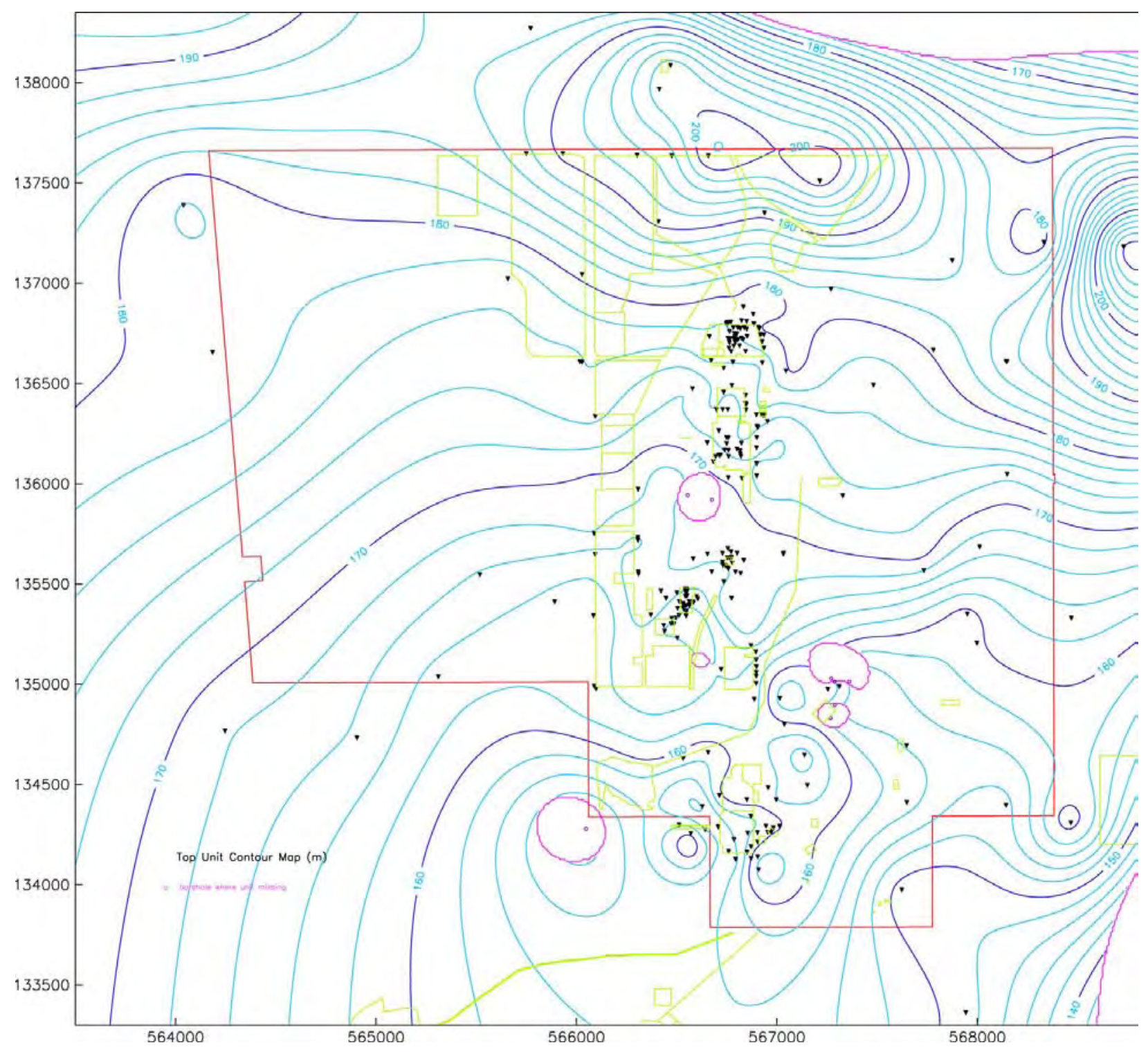

Figure C.6. Structure Contour Map for the Top of the Cold Creek Unit Carbonate Unit in and Around the 200 West Area. Contours are in meters above mean sea level (MSL). 


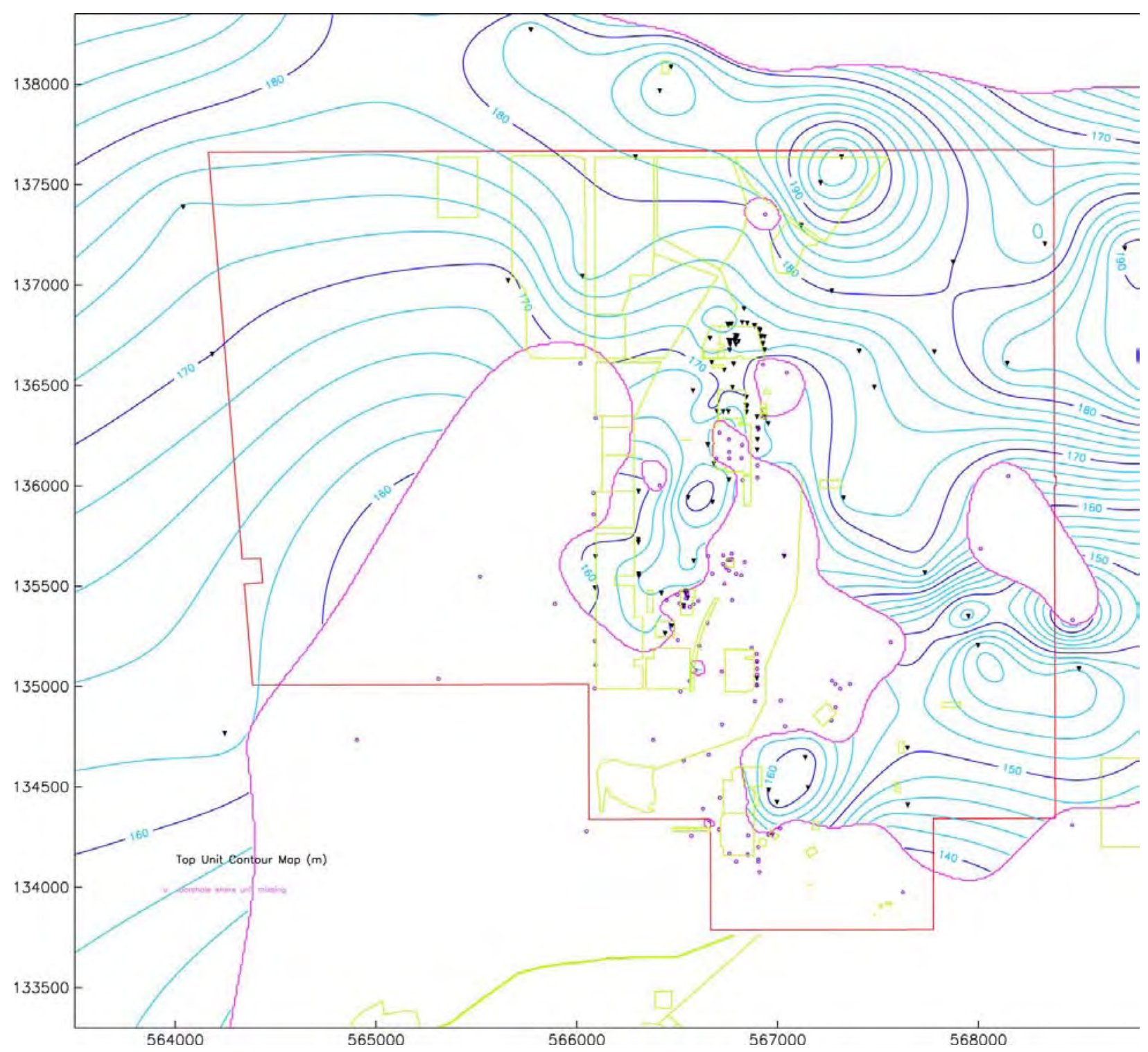

Figure C.7. Structure Contour Map for the Top of the Ringold Formation, Member of Taylor Flat, in and Around the 200 West Area. Contours are in meters above mean sea level (MSL). 


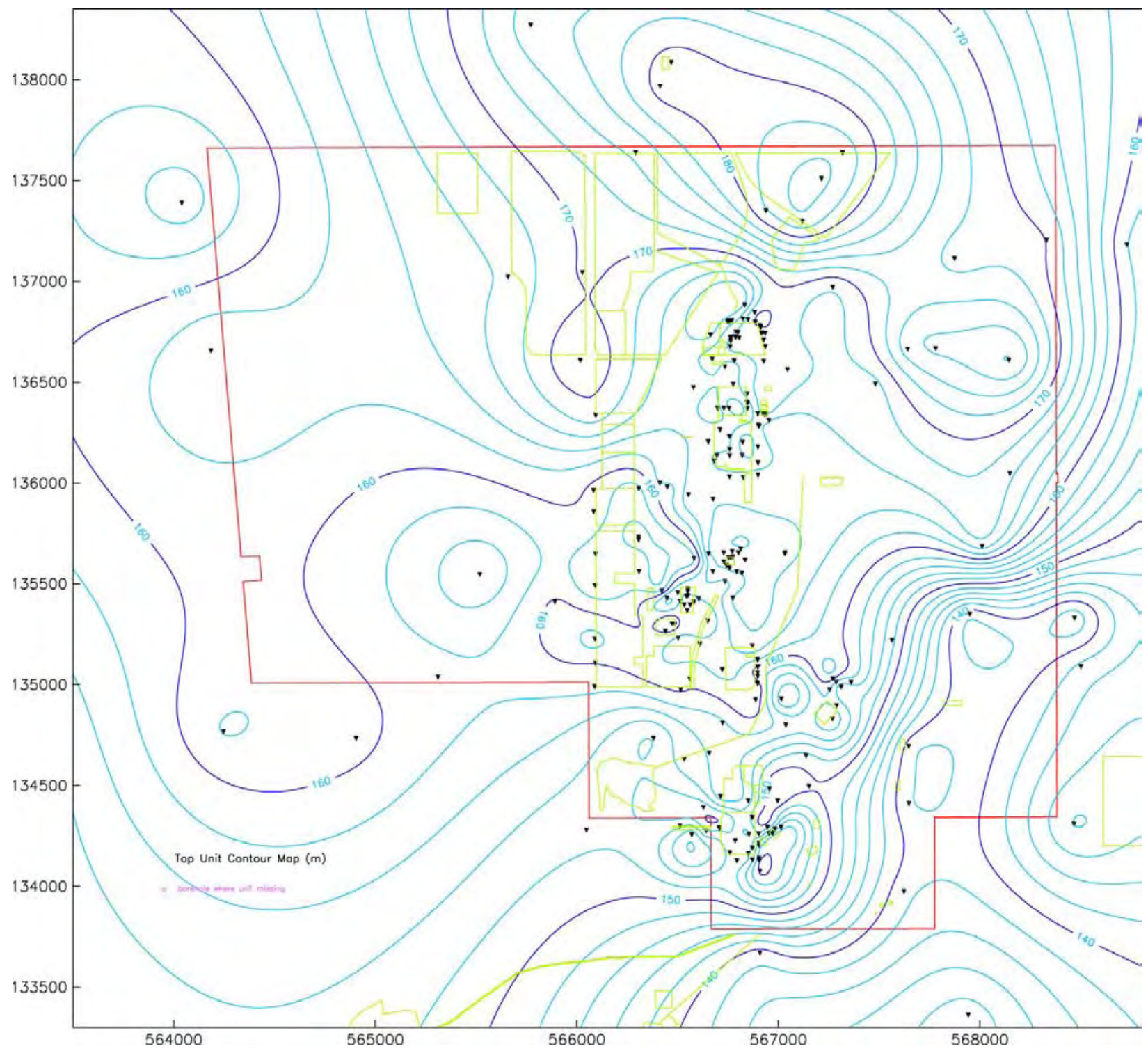

Figure C.8. Structure Contour Map of the Top of the Ringold Formation, Member of Wooded Island, Unit E, in and Around the 200 West Area. Contours are in meters above mean sea level (MSL). 


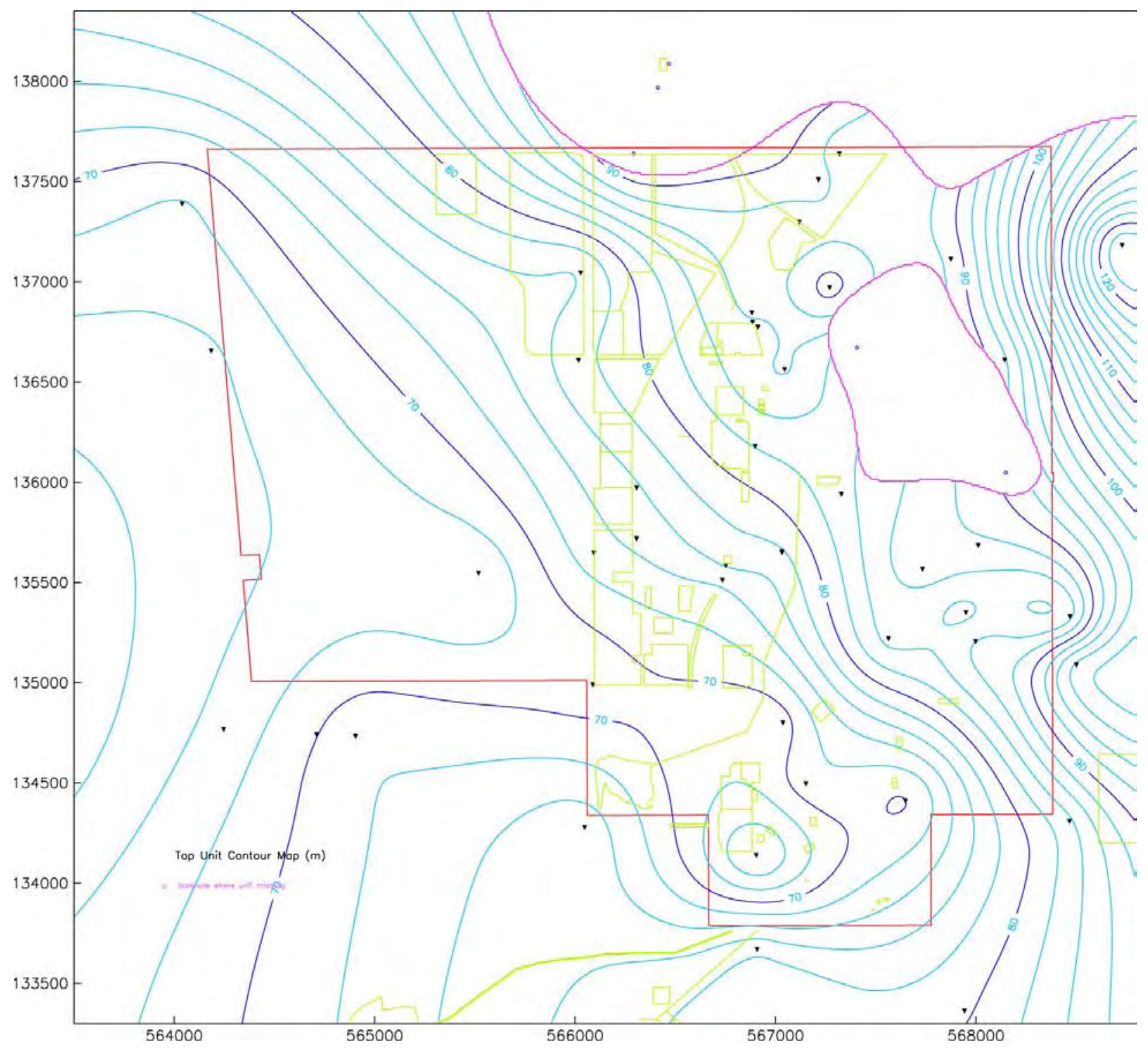

Figure C.9. Structure Contour Map of the Top of the Ringold Formation, Lower Mud Unit, in and Around the 200 West Area. Contours are in meters above mean sea level (MSL). 


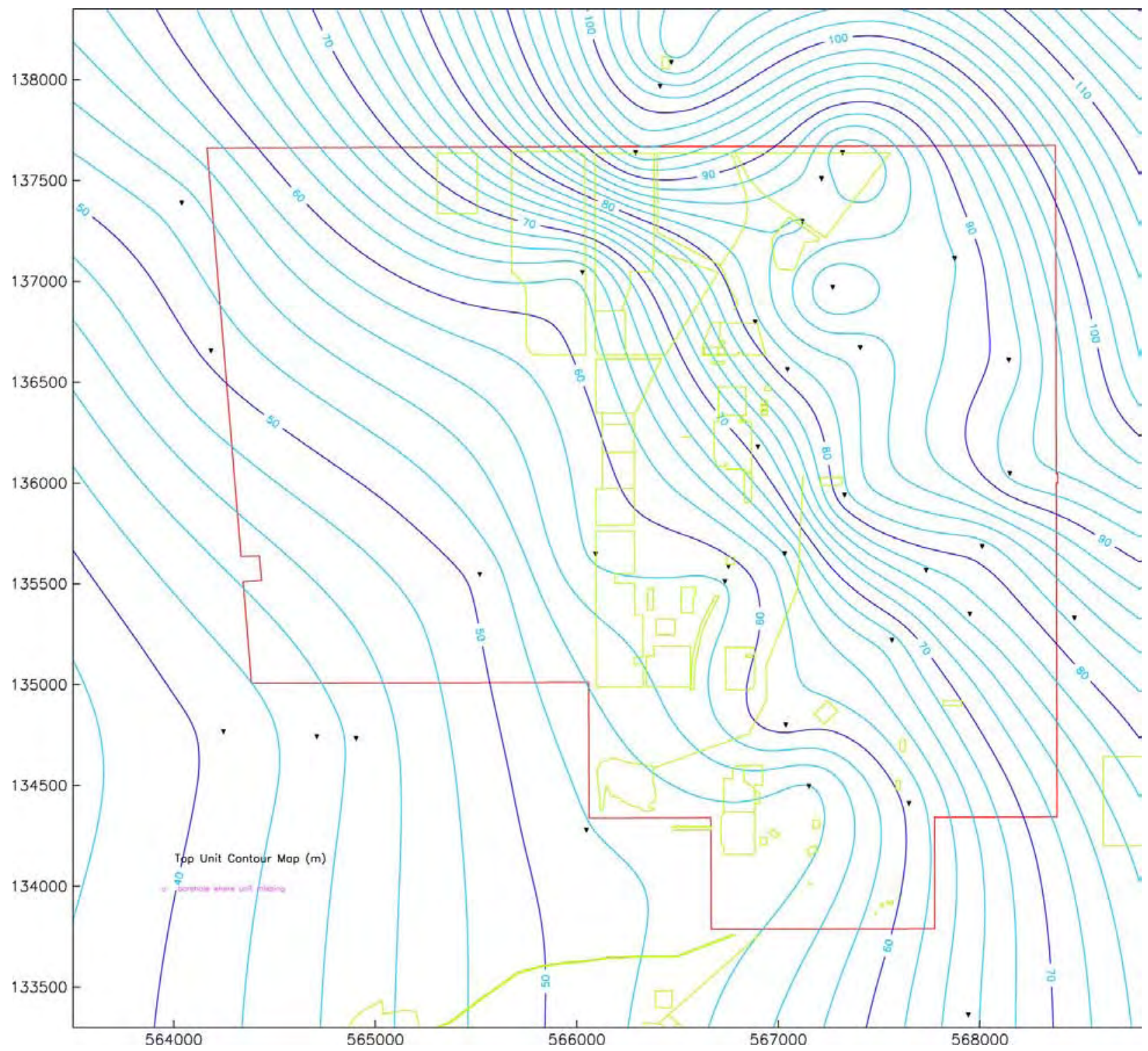

Figure C.10. Structure Contour Map of the Top of the Ringold Formation, Member of Wooded Island, Unit A, in and Around the 200 West Area. Contours are in meters above mean sea level (MSL). 


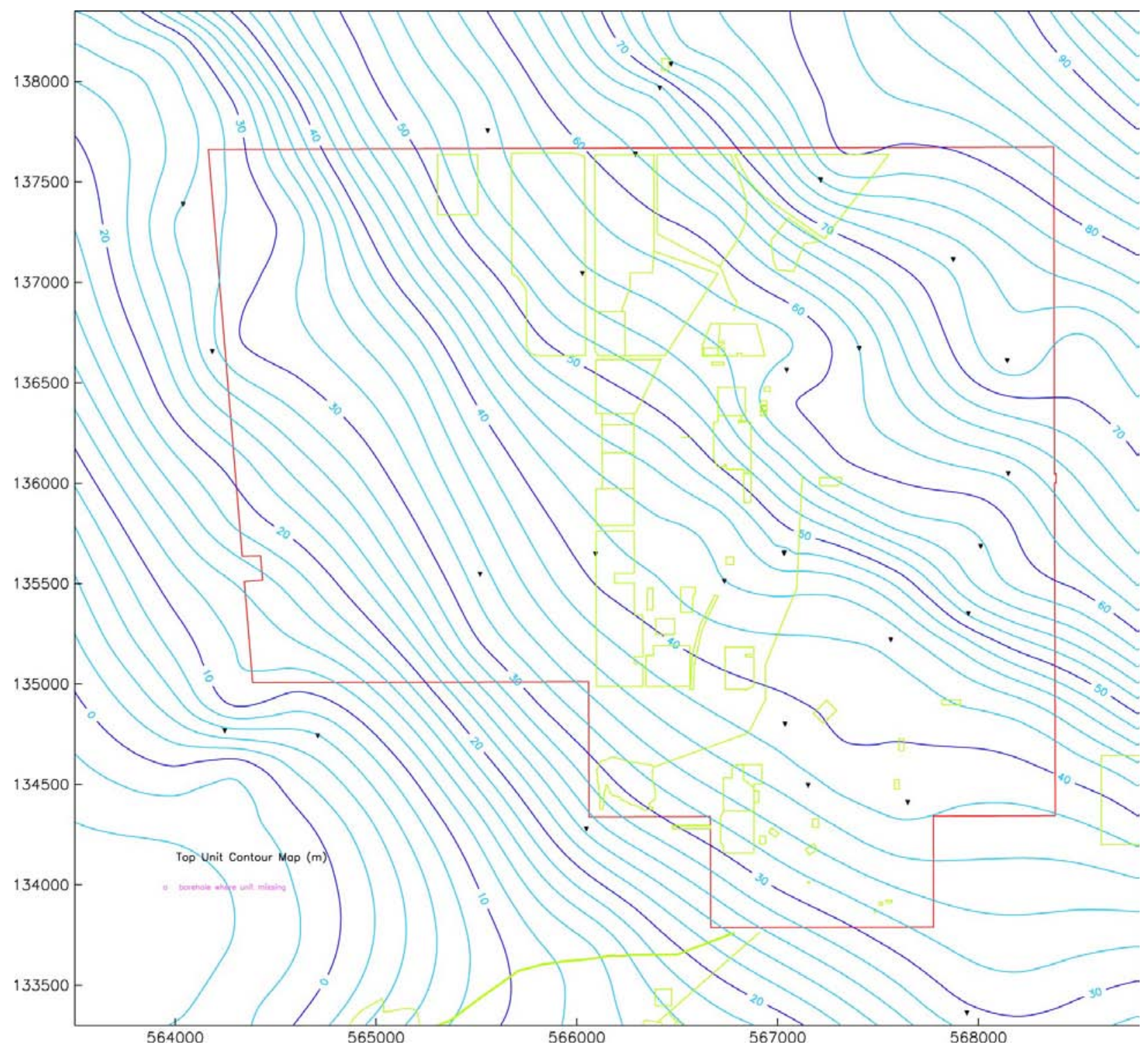

Figure C.11. Structure Contour Map of the Top of Basalt (Undifferentiated) in and Around the 200 West Area. Contours are in meters above mean sea level (MSL). 


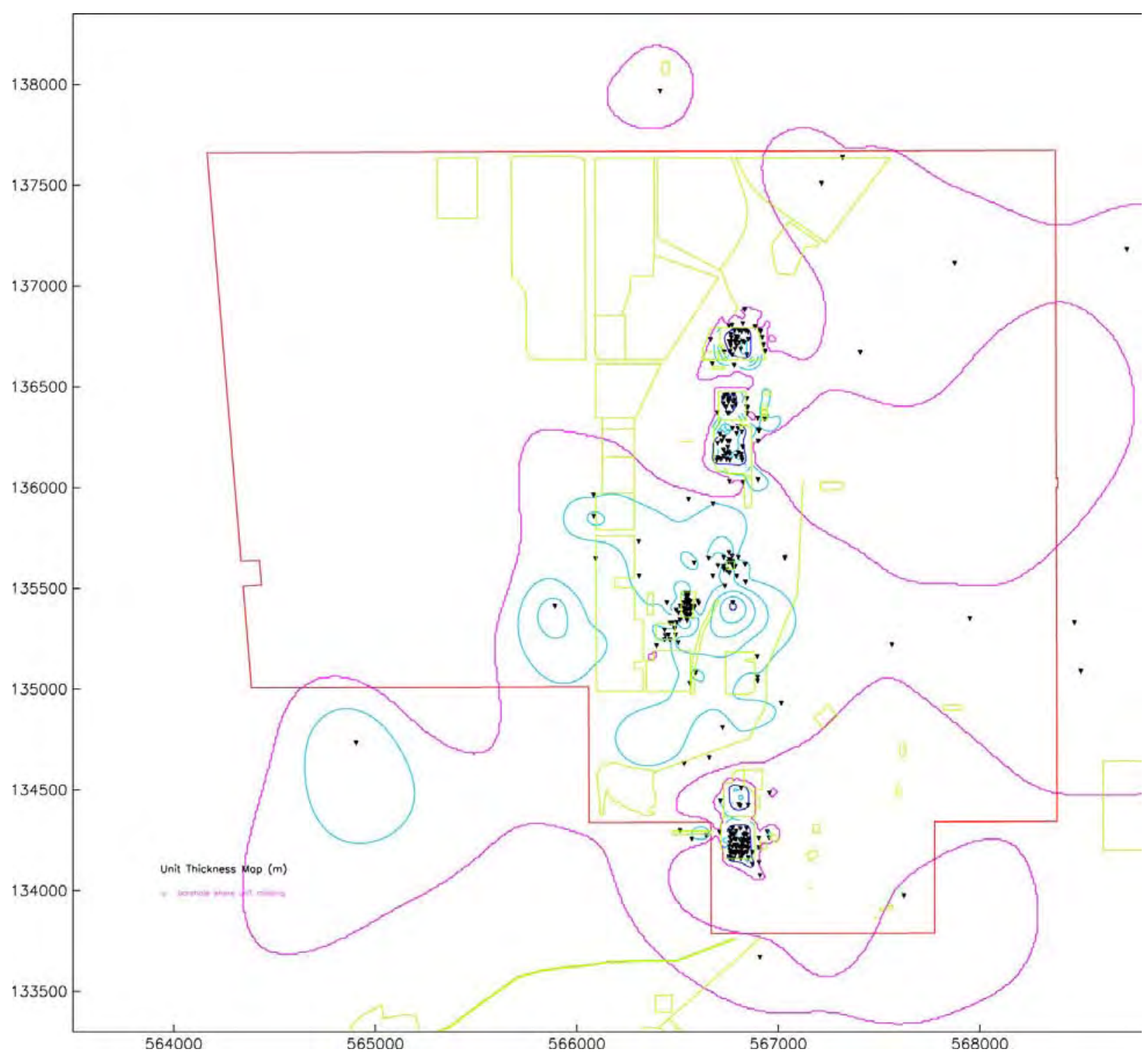

Figure C.12. Isopach Map of Holocene Deposits (Undifferentiated) in and Around the 200 West Area. The irregular surface in the central and southern 200 West Area is due to backfill associated with man-made excavations (e.g., tank farms). Contours are in meters. 


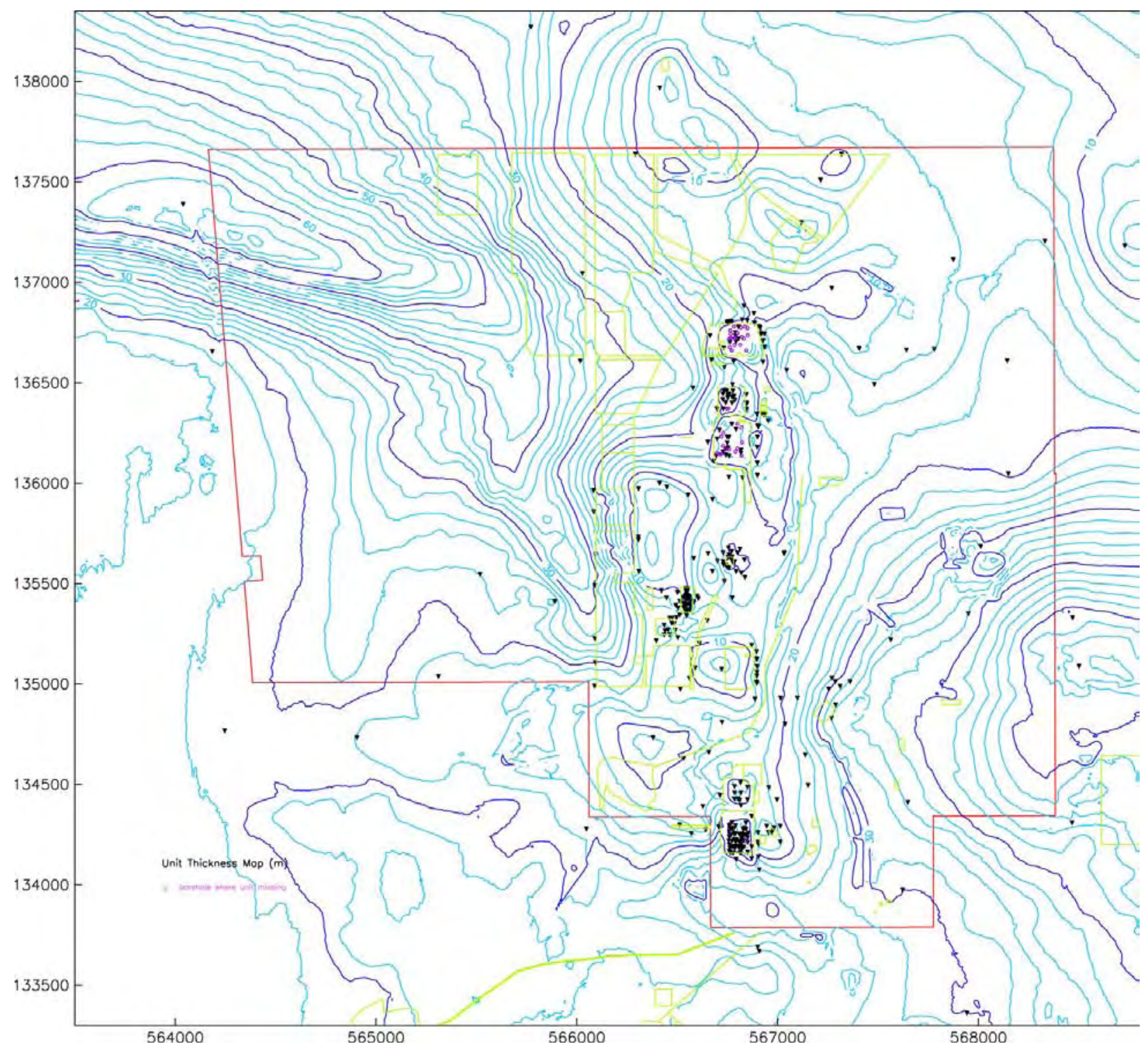

Figure C.13. Isopach Map of the Hanford H1 Unit in and Around the 200 West Area. The irregular surface in the central and southern 200 West Area is due to man-made excavations associated with subsurface facilities (e.g., tank farms). Contours are in meters. 


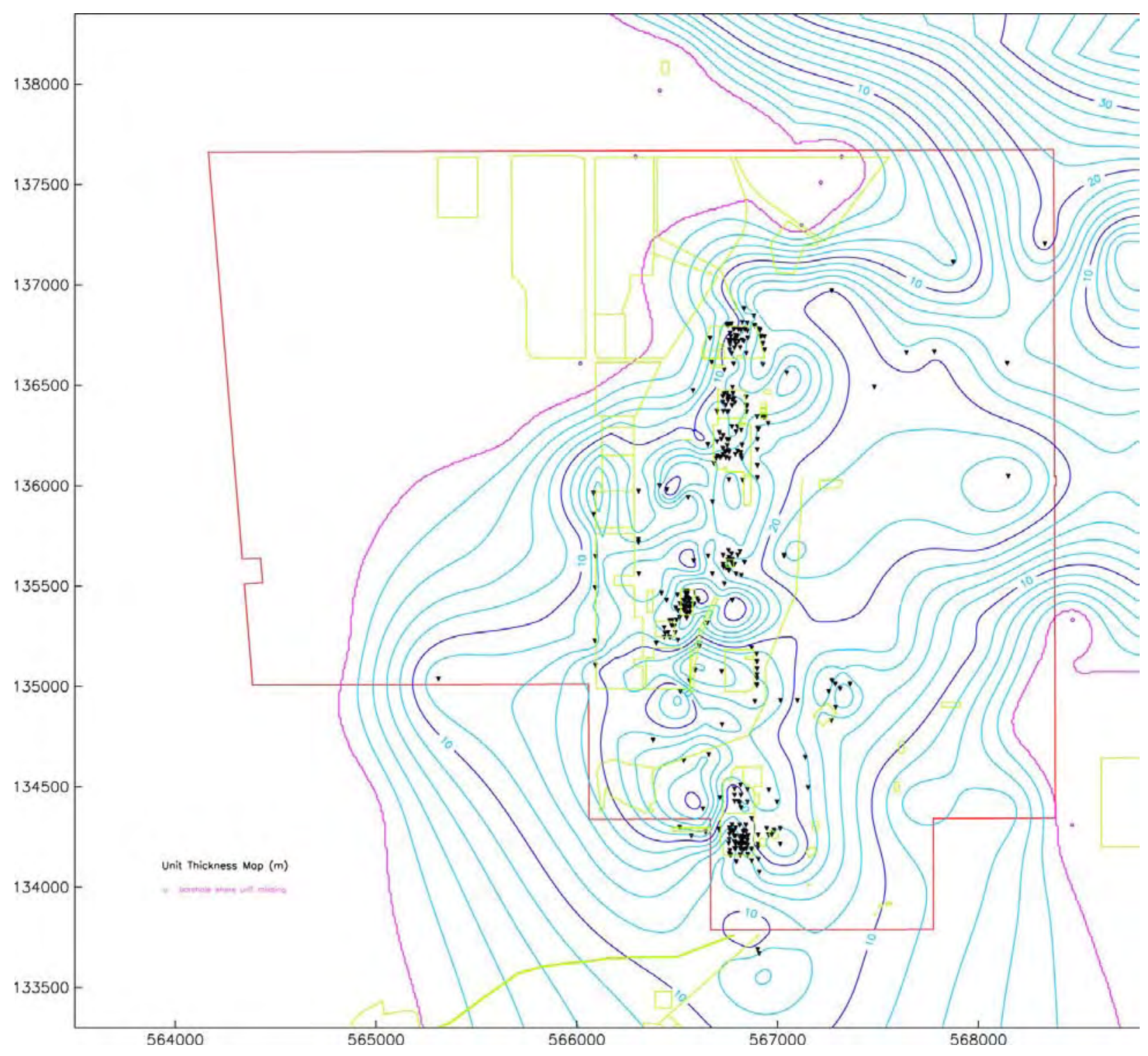

Figure C.14. Isopach Map of the Hanford H2 Unit in and Around the 200 West Area. Contours are in meters. 


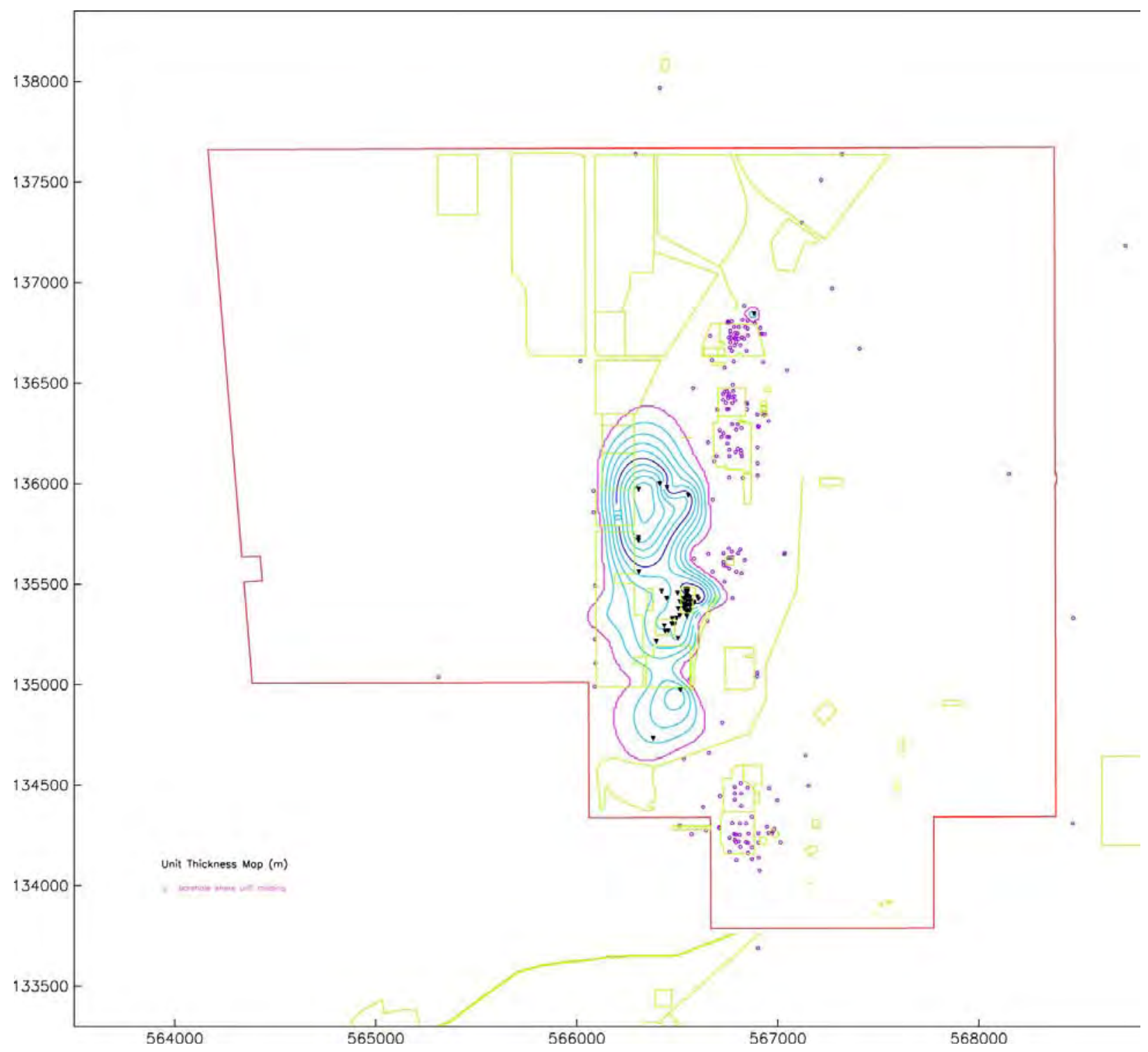

Figure C.15. Isopach Map of the Hanford H3 Unit in and Around the 200 West Area. Contours are in meters. 


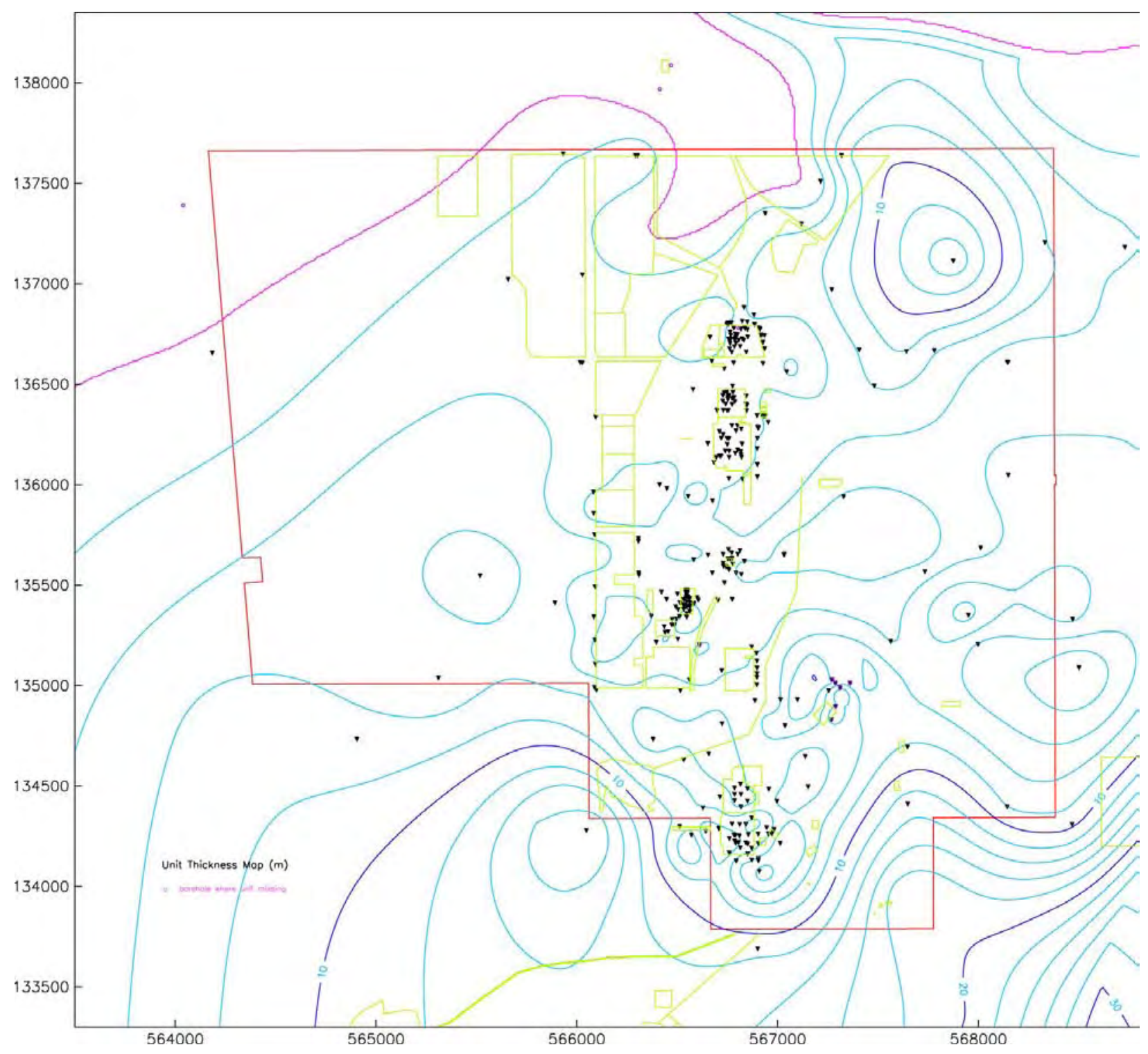

Figure C.16. Isopach Map of the Cold Creek Unit Silt in and Around the 200 West Area. Contours are in meters. 


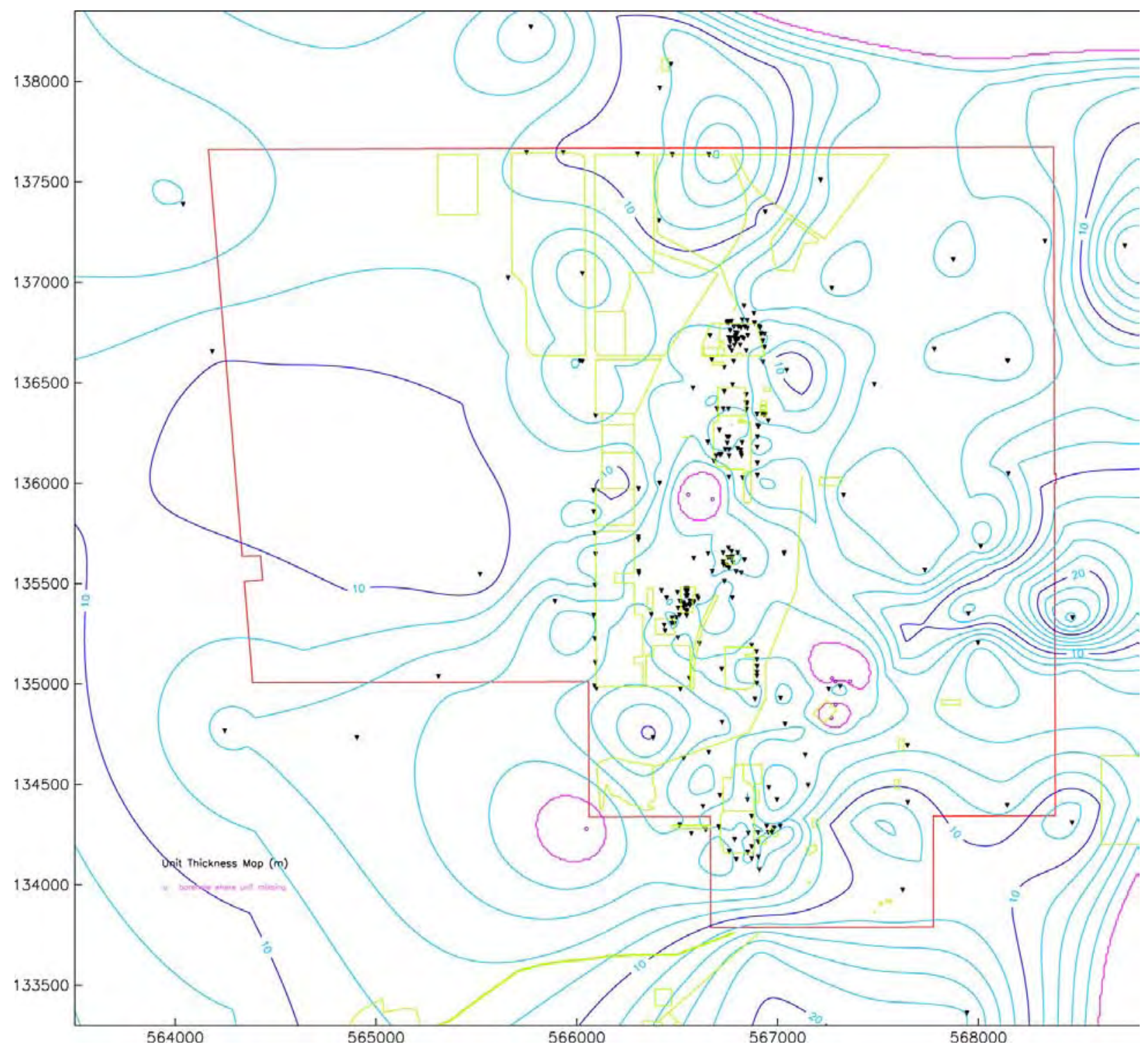

Figure C.17. Isopach Map of the Cold Creek Unit Carbonate in and Around the 200 West Area. Contours are in meters. 


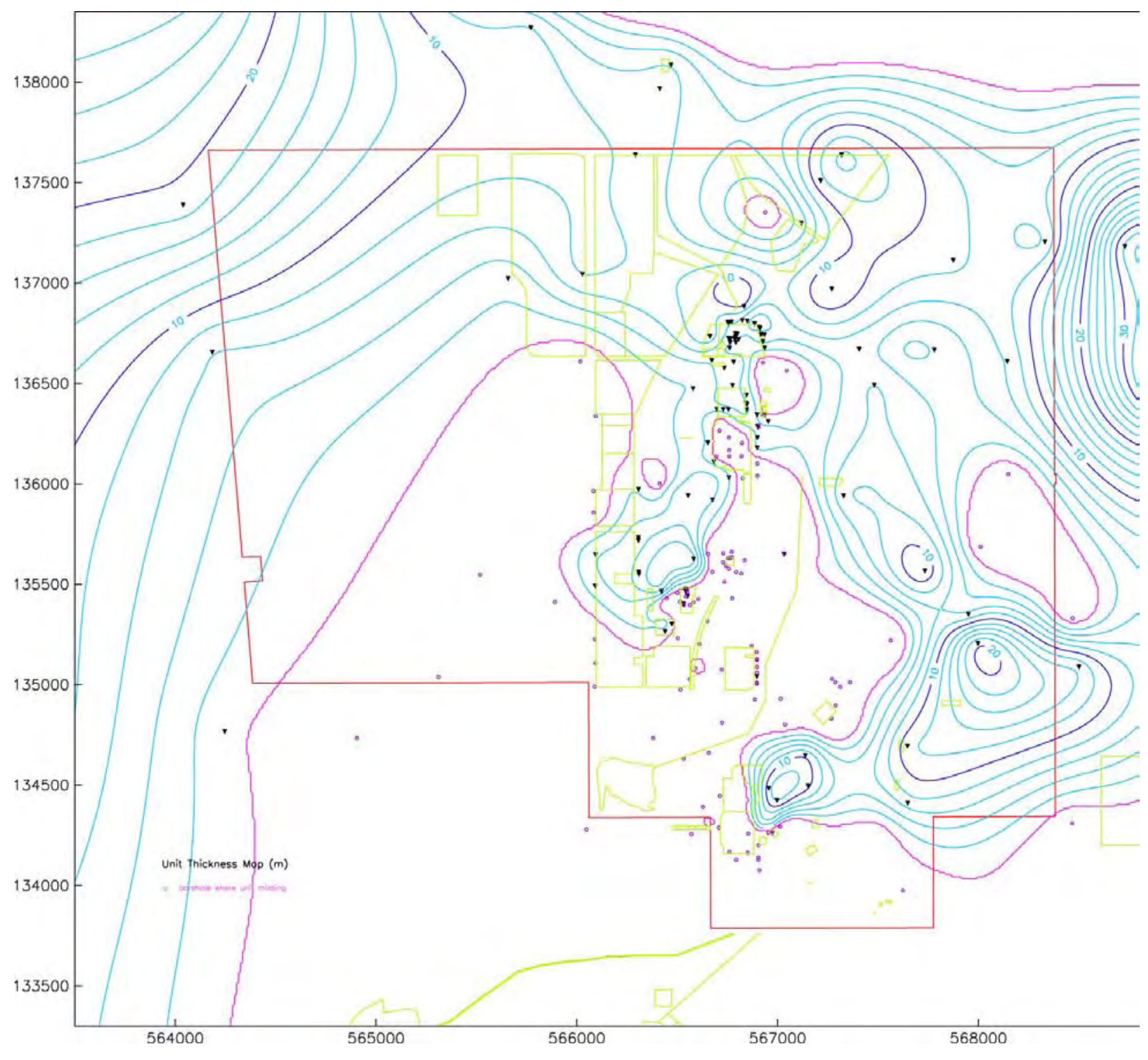

Figure C.18. Isopach Map of the Ringold Formation, Member of Taylor Flat, in and Around the 200 West Area. Contours are in meters. 


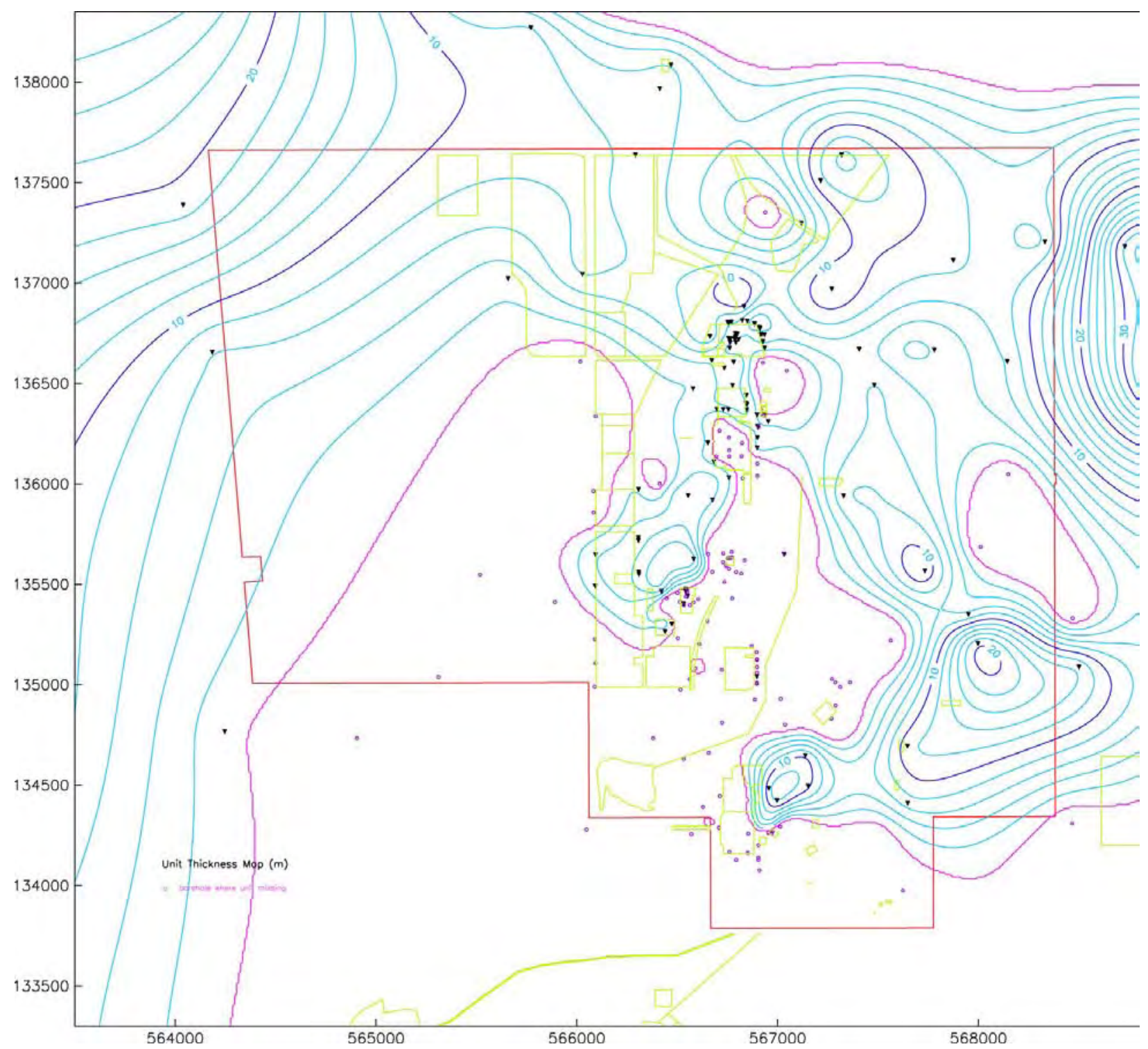

Figure C.19. Isopach Map of the Ringold Formation, Member of Wooded Island, Unit E, in and Around the 200 West Area. Contours are in meters. 


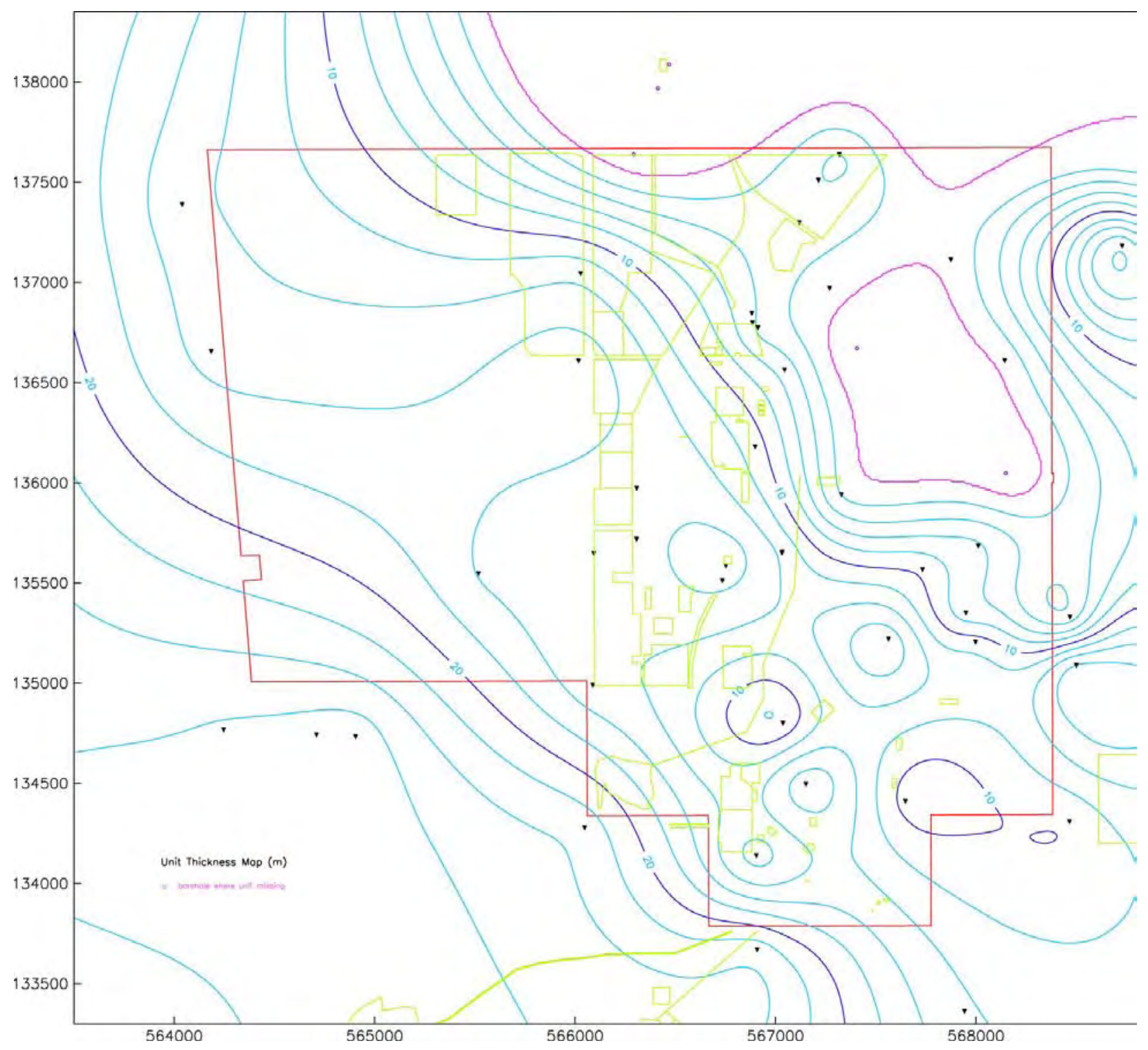

Figure C.20. Isopach Map of the Ringold Formation, Lower Mud Unit, in and Around the 200 West Area. Contours are in meters. 


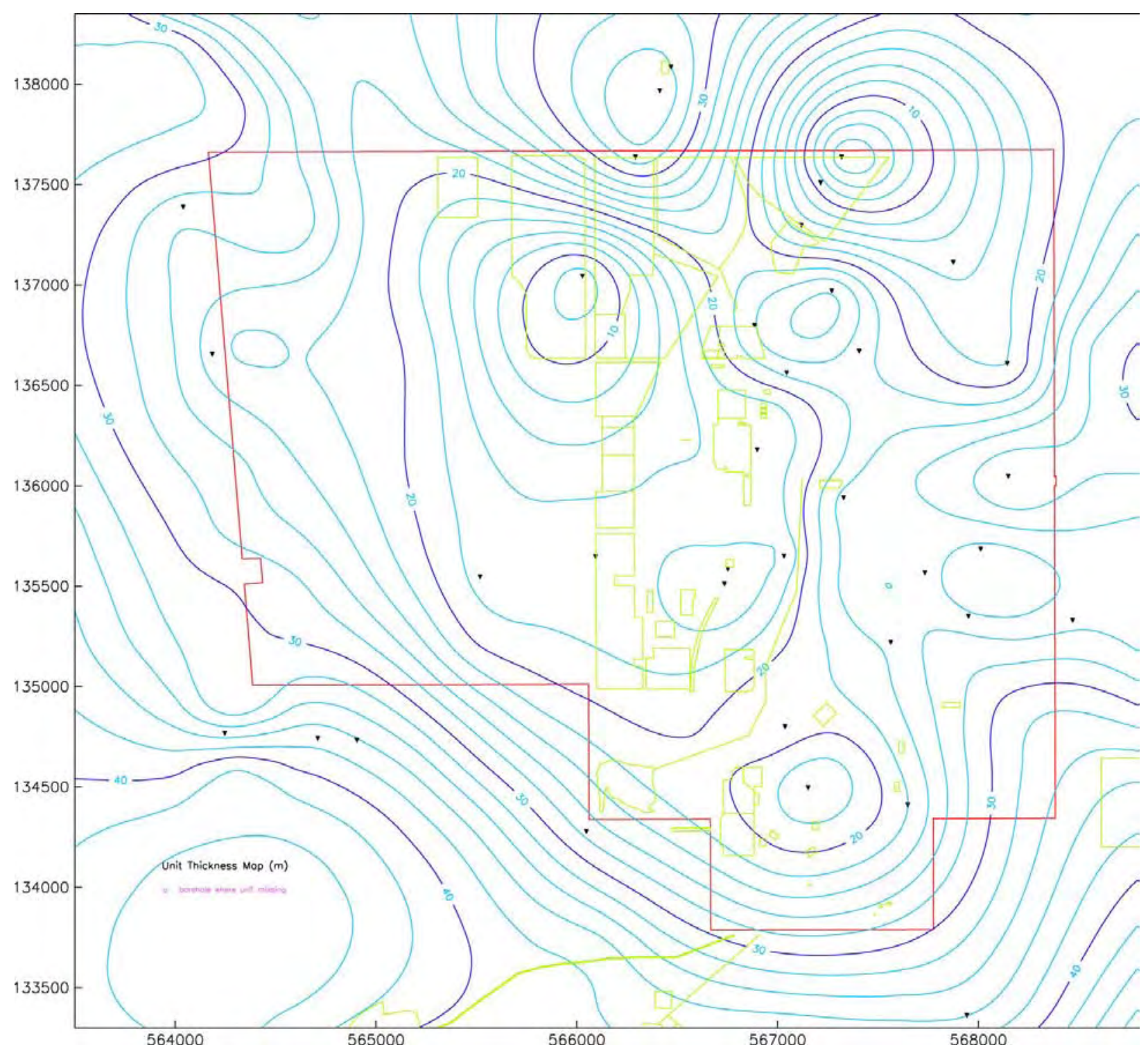

Figure C.21. Isopach Map of the Ringold Formation, Member of Wooded Island, Unit A, in and Around the 200 West Area. Contours are in meters. 


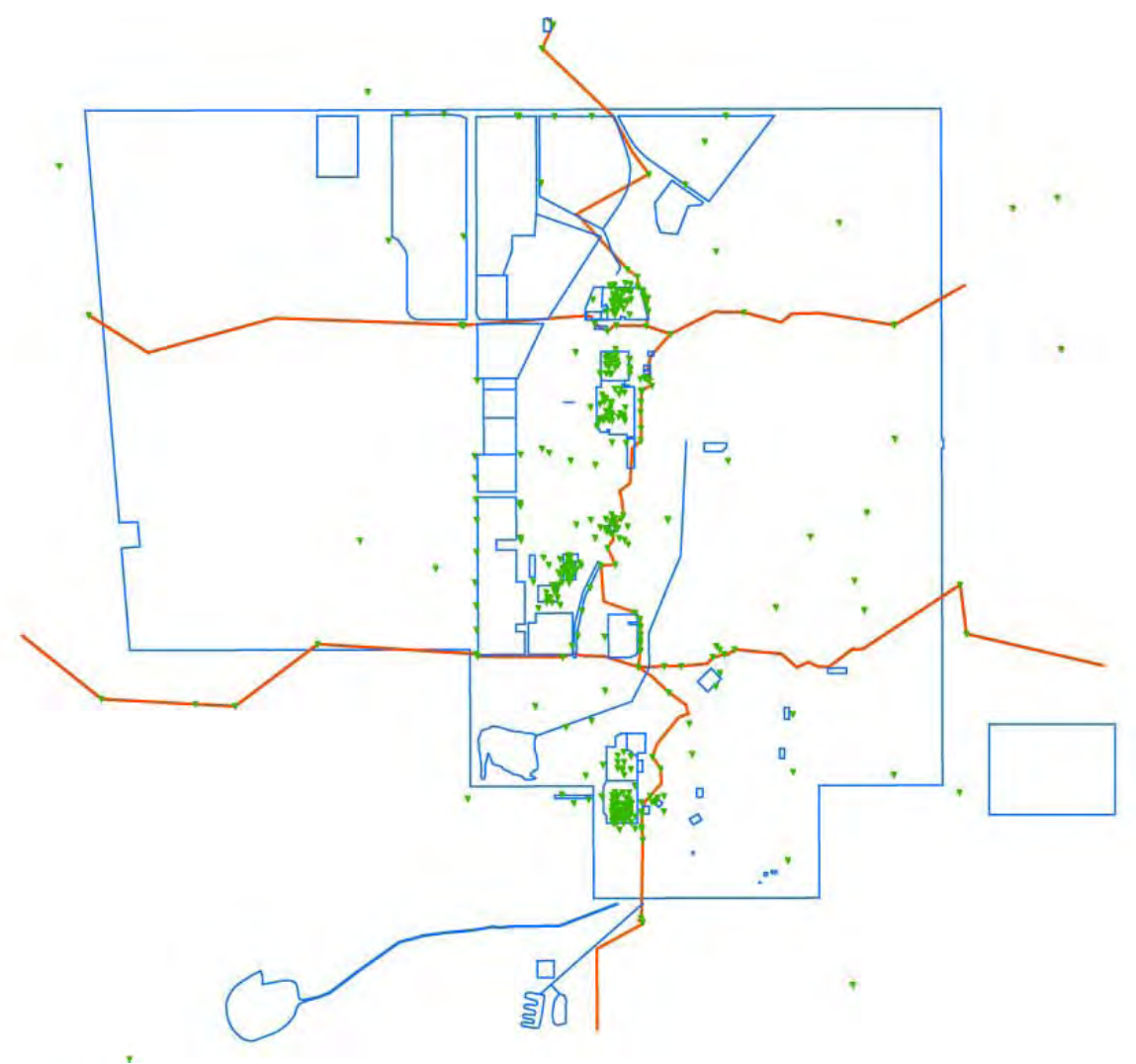

Figure C.22. Cross-Section Location Map

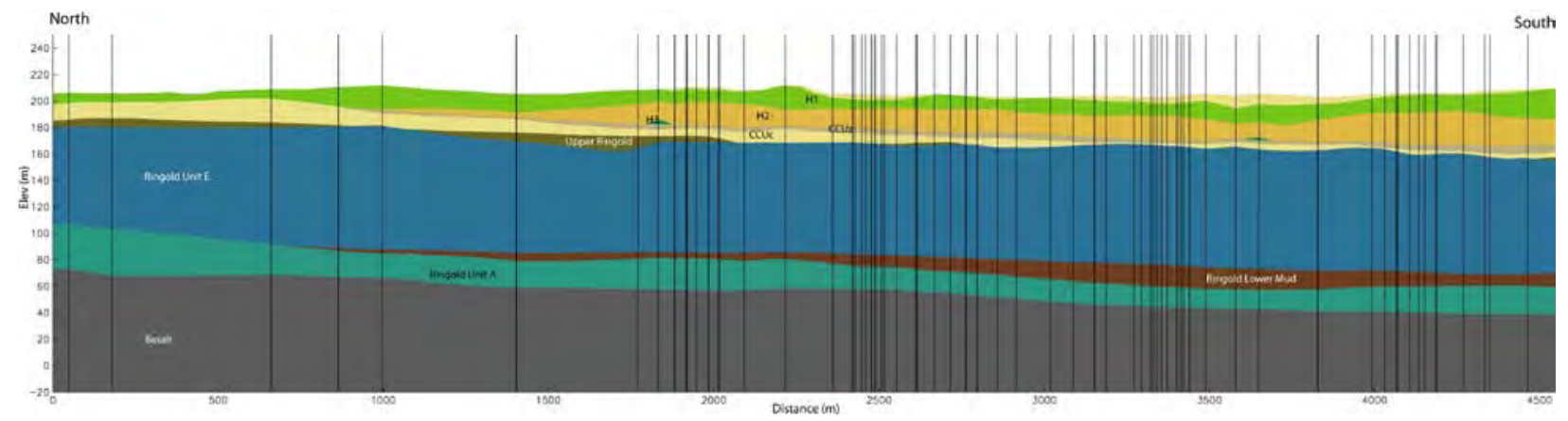

Figure C.23. North-South Cross Section B-B' 


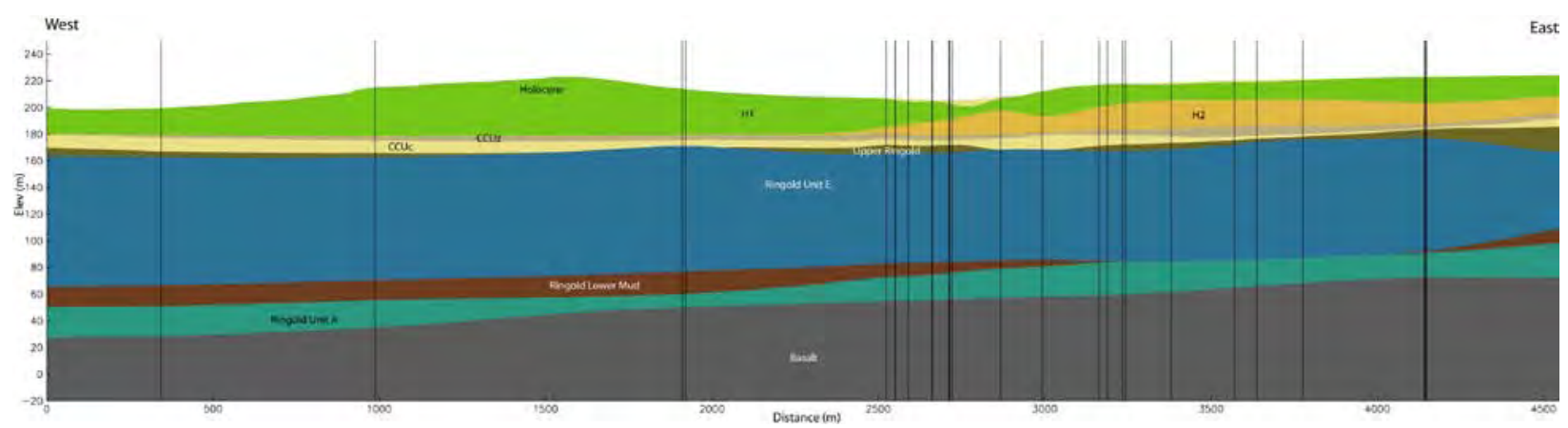

Figure C.24. East-West Cross Section F-F'

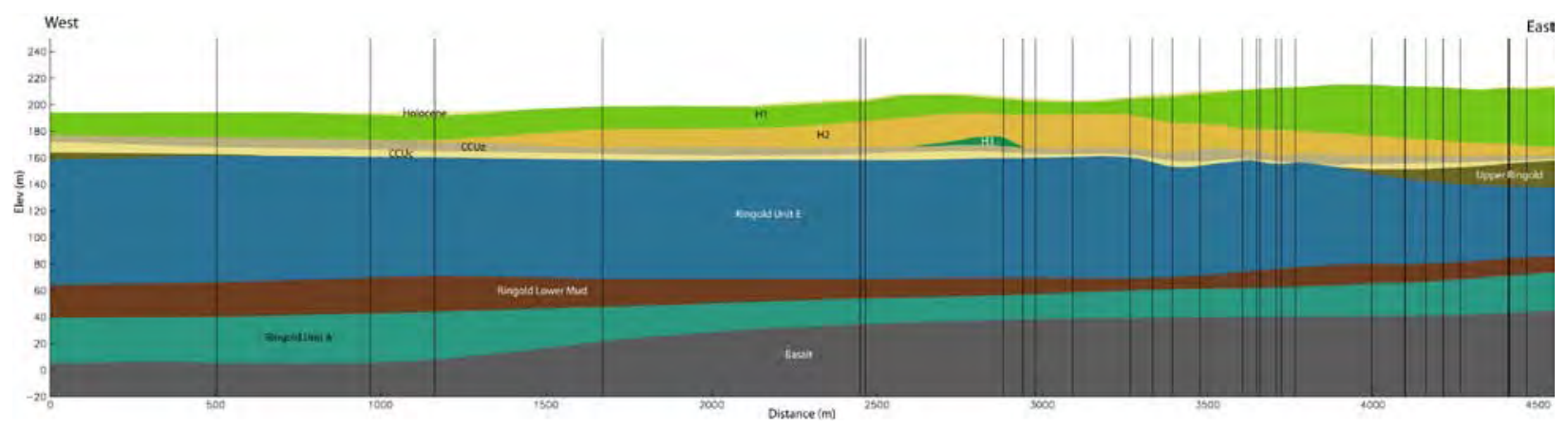

Figure C.25. East-West Cross Section I-I'

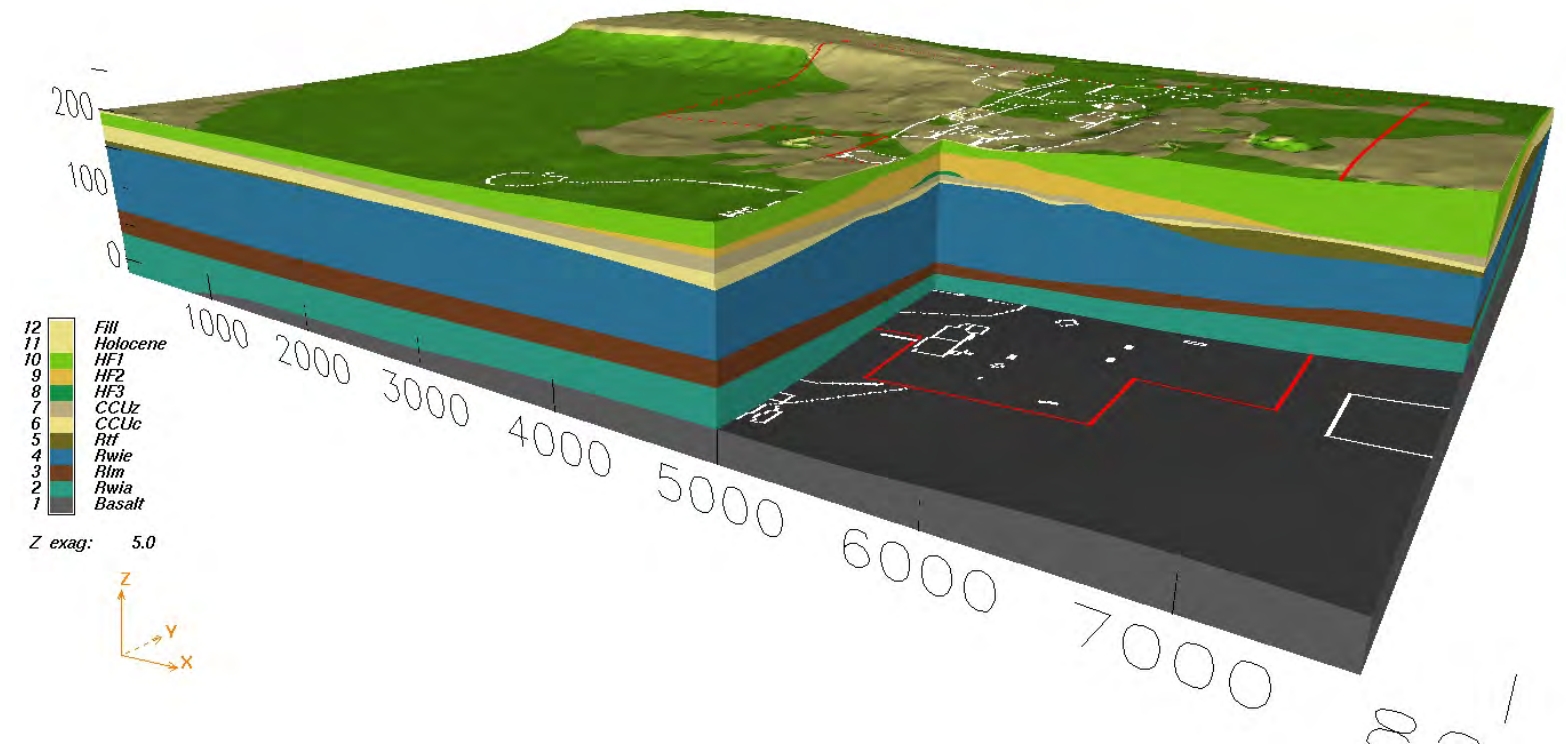

Figure C.26. Three-Dimensional Solid Earth Model with Cutout Along Cross Sections B-B' and I-I’ 


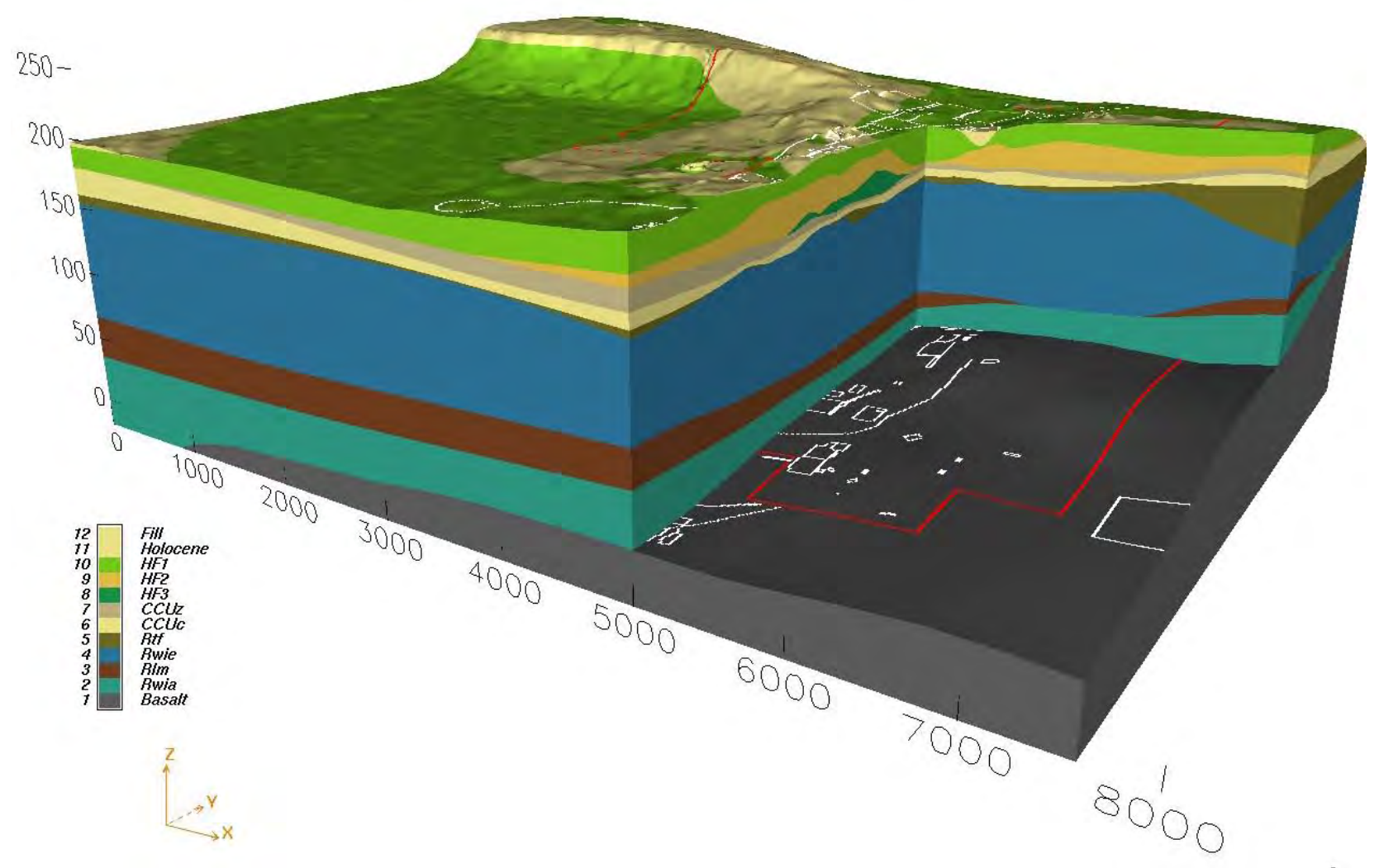

Figure C.27. Three-Dimensional Solid Earth Model with Cutout Along Cross Sections B-B' and F-F' 
Table C.1. Top Contact Elevation Data for Stratigraphic Units Used to Build EarthVision Model

\begin{tabular}{|c|c|c|c|}
\hline \multicolumn{4}{|c|}{$\begin{array}{l}\text { \# Type: Scattered data } \\
\text { \# Version: } 7 \\
\text { \# Format: Free } \\
\text { \# Field: } 1 \mathrm{x} \\
\text { \# Field: } 2 \text { y } \\
\text { \# Field: } 3 \text { z meters } \\
\text { \# Field: } 4 \text { Wellid non-numeric } \\
\text { \# Projection: State Plane } \\
\text { \# Zone: } 4602 \text {-- Washington (South) } \\
\text { \# Units: Meters } \\
\text { \# Ellipsoid: GRS 1980/NAD83 } \\
\text { \# End: }\end{array}$} \\
\hline 566752.23 & 135586.67 & 59.27 & W15-46 \\
\hline 566093.439 & 135648.274 & 58.42 & W15-14 \\
\hline 566734.978 & 135511.737 & 57.98 & W15-5 \\
\hline 564904.599 & 134733.616 & 44.37 & 699-37-82B \\
\hline 562367.221 & 142612.351 & 105.65 & 699-63-90 \\
\hline 568967.03 & 136488.48 & 106.14 & 699-43-69 \\
\hline 565637.671 & 141574.964 & 155.65 & 699-59-80B \\
\hline 560944.724 & 140231.066 & 96.04 & 699-55-95 \\
\hline 566723.421 & 140225.816 & 133.01 & 699-55-76 \\
\hline 568529.958 & 140318.965 & 146.61 & $699-55-70$ \\
\hline 566978.076 & 138906.286 & 114.87 & 699-51-75 \\
\hline 570664.4 & 139148.408 & 120.56 & 699-51-63 \\
\hline 559791.933 & 138597.775 & 101.32 & 699-50-99 \\
\hline 560498.644 & 138598.927 & 52.09 & 699-50-96 \\
\hline 564039.49 & 137389.363 & 53.15 & 699-46-85B \\
\hline 566047.649 & 134279.214 & 51.89 & 699-35-78B \\
\hline 564130.196 & 138669.323 & 63.31 & 699-50-85 \\
\hline 567031.755 & 135650.695 & 63.92 & W14-9 \\
\hline 566468.954 & 138086.801 & 108 & 699-48-77C \\
\hline 566413.228 & 137968.857 & 103.51 & 699-48-77A \\
\hline 561961.05 & 137899.21 & 50.9 & 699-47-92A \\
\hline 564184.494 & 136656.217 & 50.53 & 699-43-84 \\
\hline 565518.011 & 135547.796 & 50.59 & $699-40-80$ \\
\hline 571474.38 & 137968.732 & 129.93 & 699-47-60 \\
\hline 566027.833 & 137045.119 & 62.58 & 699-45-78 \\
\hline 568947.12 & 137233.81 & 111.95 & 699-45-69C \\
\hline 570390.651 & 136897.434 & 119.29 & 699-44-64P \\
\hline 570390.651 & 136897.434 & 119.4 & 699-44-64 \\
\hline 562186.522 & 136693.27 & 33.61 & 699-43-91B \\
\hline 561920.394 & 134597.154 & 34.67 & 699-37-92 \\
\hline 562880.724 & 134737.896 & 33.93 & 699-37-89 \\
\hline 570057.48 & 135881.16 & 98.36 & 699-40-65 \\
\hline 568469.1 & 135331.04 & 82.53 & 699-38-70B \\
\hline 571401.207 & 134586.889 & 83.45 & 699-36-61B \\
\hline 567318.74 & 137638.72 & 82.39 & W6-6 \\
\hline 567118.18 & 137299.13 & 83.82 & W6-3 \\
\hline
\end{tabular}




\begin{tabular}{llll}
570090.185 & 135039.847 & 92.25 & $699-38-65$ \\
568148.74 & 136048.6 & 92.66 & W13-1 \\
564246.757 & 134768.37 & 40.51 & $699-37-84$ \\
564383.098 & 132999.147 & 41.92 & $699-31-84 A$ \\
564709.845 & 134742.796 & 43.11 & $699-37-83$ \\
575556.97 & 134893.26 & 85.68 & $699-37-47 A$ \\
569857.861 & 134099.244 & 85.99 & $699-35-66 A$ \\
567406.278 & 136671.046 & 84.87 & W11-2 \\
567214.128 & 137510.135 & 84.86 & W6-1 \\
567942.676 & 133362.612 & 65.38 & $699-32-72 A$ \\
567151.707 & 134496.761 & 53.75 & W22-27 \\
567648.17 & 134410.86 & 60.55 & W22-24 \\
567036.972 & 134800.753 & 60.87 & W19-10 \\
567563.693 & 135220.291 & 67.24 & W19-8 \\
567949.931 & 135350.792 & 76.65 & W19-4 \\
567733.43 & 135567.81 & 77.67 & W14-71 \\
567328.44 & 135941.28 & 81.71 & W14-72 \\
568011.141 & 135685.695 & 81.21 & W14-8B \\
567045.135 & 136563.735 & 81.1 & W11-26 \\
566885.426 & 136798.78 & 81.57 & W10-24 \\
566898.386 & 136181.048 & 71.12 & W14-14 \\
567874.67 & 137113.09 & 87.92 & W11-88 \\
568143.53 & 136610.04 & 91.01 & W11-86 \\
567269.74 & 136971.04 & 89.94 & W11-43 \\
566292.031 & 137638.641 & 95.2 & W7-3 \\
\hline
\end{tabular}




\section{Appendix D}

\section{Detailed Geologic Cross Sections}

Through the 200 West Area 


\section{Appendix D}

\section{Detailed Geologic Cross Sections Through the 200 West Area}

The details of cross sections B-B' and F-F' are provided on the following pages. 








\section{Distribution}

No. of

Copies

\section{OFFSITE}

S. P. Airhart

Freestone Environmental Services, Inc.

1100 Jadwin Ave., Suite 250

Richland, WA 99352

P. Cabbage

Freestone Environmental Services, Inc.

1100 Jadwin Ave., Suite 250

Richland, WA 99352

K. Royal

Freestone Environmental Services, Inc. 1100 Jadwin Ave., Suite 250

Richland, WA 99352

J. Ludwig

INTERA, Inc.

1933 Jadwin Ave., Suite 130

Richland, WA 99354

M. J. Tonkin

INTERA, Inc.

1933 Jadwin Ave., Suite 130

Richland, WA 99354

\section{ONSITE}

\section{DOE Office of River Protection}

R. W. Lober

H6-60

DOE Public Reading Room (2)

H2-53

\section{DOE Richland Operations Office}

B. L. Foley

J. P. Hanson

R. D. Hildebrand

J. G. Morse

K. M. Thompson

A5-13

A6-38

A6-38

A6-38
No. of

Copies

22 CH2M-HILL Plateau Remediation

Company, Inc.

G. D. Cummins

H8-15

R. E. Day

H8-15

M. H. Doornbos

H8-15

B. H. Ford

H8-43

J. D. Hoover

H8-15

M. N. Jaraysi

H8-43

J. W. Lindberg

R3-50

J. A. Lowe

H8-51

D. E. McKenney

H8-43

W. J. Mcmahon

H8-51

C. W. Miller

H8-15

V. J. Rohay

H8-15

L. C. Swanson

R3-70

G. S. Thomas

R3-50

M. D. Thompson

H8-15

W. D. Webber

H8-15

B. A. Williams (4)

H8-51

C. D. Wittreich

H8-15

M. I. Wood

H8-51

\section{Fluor Federal Services}
K. M. Davis
H8-15
R. Khaleel
R3-50
D. L. Morgans
H8-51
R. J. Puigh
H8-27
P. Rogers
R3-32

\section{INTERA, Inc.}
A. H. Aly
H8-15
S. Mehta
H8-51
W. E. Nichols
H8-15

3 Washington River Protection Solutions
M. P. Connelly
S7-66
S. J. Eberlein
S7-66
D. A. Myers
S7-66 
No. of

Copies

24 Pacific Northwest National Laboratory

B. N. Bjornstad (2)

K. J. Cantrell

M. J. Fayer

M. D. Freshley

J. D. Horner (2)

D. C. Lanigan (2)

G. V. Last (4)
No. of

Copies
K6-81

K6-81

K9-33

K9-33

K6-96

K6-75

K6-81
R. D. Mackley (2) K6-96

C. J. Murray

K6-81

K. R. Parker (2) K6-96

R. G. Riley K6-81

M. L. Rockhold K9-33

R. J. Serne K6-81

P. D. Thorne (2) K6-96

Information Release Office 


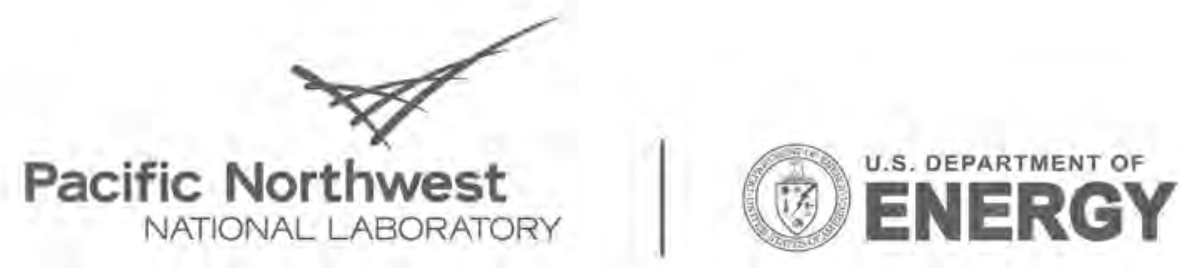

Prondly Operated by Battelle Since 1965

902 Battelle Boulevard

P.O. Box 999

Richland, WA 99352

1-888-375-PNNL (7665)

www.pni,gov 